ISAAC WATTS: REASON, PASSION AND THE REVIVAL OF RELIGION

Graham Beynon

A Thesis Submitted for the Degree of PhD at the

University of St Andrews

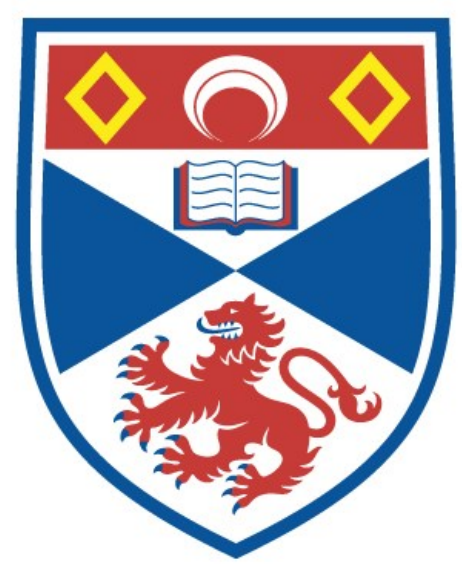

2013

Full metadata for this item is available in

St Andrews Research Repository

at:

http://research-repository.st-andrews.ac.uk/

Please use this identifier to cite or link to this item:

http://hdl.handle.net/10023/3614

This item is protected by original copyright 


\title{
Isaac Watts: Reason, Passion and the Revival of Religion
}

\author{
Graham Beynon
}

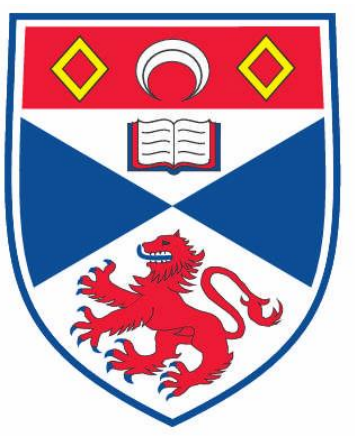

This thesis is submitted in partial fulfilment for the degree of PhD at the

University of St Andrews

September 2012 


\section{Acknowledgments}

The idea of a thesis on Isaac Watts first arose in my mind while reading a biography on a summer holiday. So my first acknowledgment is to David Fountain for writing an engaging study of Watts that led me to want to read more.

The decision to actually do a $\mathrm{PhD}$ then became involved with a major family move and a career break. So my heartfelt thanks go to my wife Charis for her support and encouragement. Also to my children, Cara, Isaac and Jed, who bore with the changes in life with good grace knowing it was for their Dad's project and future work.

Then came finding a supervisor. I still remember the first reply from Dr Stephen Holmes as to whether he was interested, 'On Watts, always.' Dr Holmes has been cheerfully encouraging and patiently directing to this mature student who didn't quite know what he was doing.

Various libraries have of course played their part. So my thanks go to the very helpful staff of Tyndale House in Cambridge; Cambridge University Library; the British Library; and, the Dr Williams's Library.

Others have given their guidance and encouragement. Dr Robert Strivens passed on helpful reference material and allowed me to see his work on Philip Doddridge. Mr Lee Gatiss kindly read a draft of this thesis and made a variety of helpful comments especially on Puritan background. Dr John Coffey also read through chapters as I wrote them and showed his comprehensive awareness of the topic with helpful suggestions and encouragement. Within the community at Tyndale House where much of this thesis was written there have been numerous friendships and encouraging words.

I also gratefully acknowledge a grant from The Pratt Green Trust during my first year of study.

Above all I acknowledge and thank God in his grace, his gifting, and his goodness. 


\section{Abstract}

Isaac Watts was a dissenting minister, theologian, philosopher, hymn writer and poet in the first half of the eighteenth century. Despite exercising significant influence over dissent and beyond he remains an understudied figure. In particular there has been little attempt to find coherent patterns of thought in his works.

We examine Watts' view of the role of reason and the place of passion in the Christian life. These are shown to be foundational themes in his thought. In particular they lie behind his more practical works which attempted to bring reformation and revival to the church of his day.

On reason Watts in many ways followed Enlightenment thought as expressed by John Locke. However he departed in significant ways which echo his Puritan background. As a result Watts is shown to be an 'Enlightenment Puritan' on this topic. On passion Watts accepted some of the view of the new sentimentalist thinkers but again continued significant elements of Puritan thought. Hence on both these areas Watts is shown to hold a modified Puritan position, modified that is in the light of the new thinking of his day.

Watts' position on these foundational topics is then shown to lie behind his attempts to revive religion in the areas of preaching, praise and prayer. Watts' distinct views on these practical topics are shown to flow directly from his view of reason and passion. Hence in a time of increasing rationalism and sentimentality in the church Watts attempted to bring revival because of his modified Puritan views on reason and passion.

As a result Watts' thought is shown to have a far greater degree of consistency than has been previously appreciated. It is not claimed that Watts has been relocated but that we have located him far more precisely. 


\section{Contents}

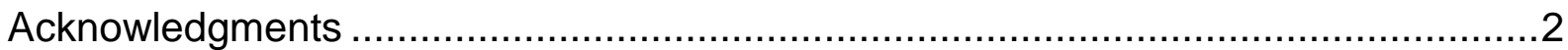

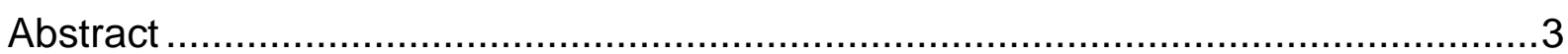

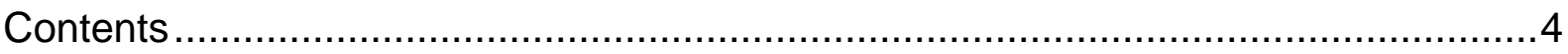



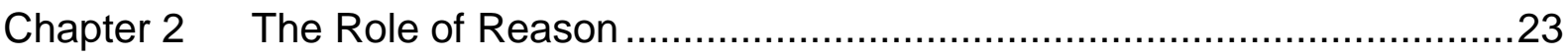

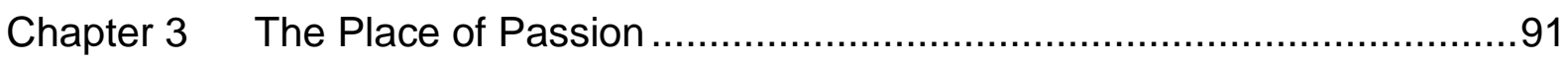

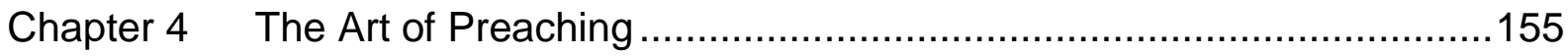

Chapter 5 The Need for Praise ................................................................

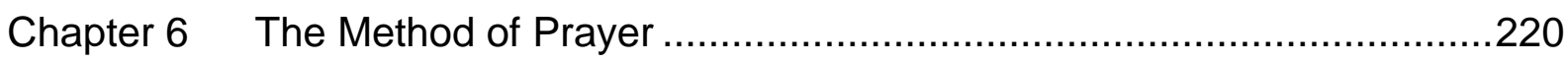

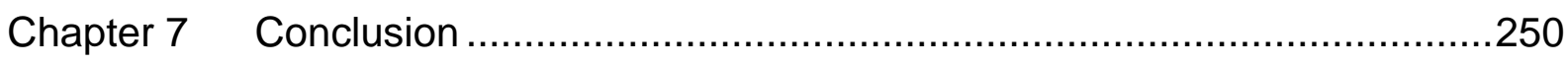

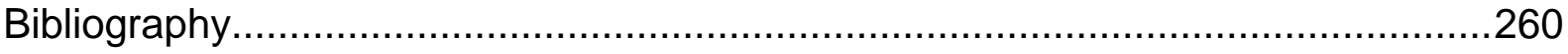




\section{Chapter 1 Introduction}

\section{Introduction}

Isaac Watts was a dissenting minister, theologian, philosopher, poet, and hymn writer in the first half of the eighteenth century (1674-1748). He is famous today for his hymns which is where his true genius lay. However his theological, pastoral, and educational works were of great significance and influence in his own day and beyond. Despite this Watts' prose works have received relatively little attention. In particular there have been few attempts to find coherent patterns in Watts' thought. The most recent intellectual biography was published in $1943 .{ }^{1}$ There have been a few significant book chapters and papers examining aspects of Watts' thought since then, but as Alan Sell says with regard to Watts' philosophical works, he 'deserves more attention than he ordinarily receives. ${ }^{2}$

Watts' most recent significant biographer, Arthur Davis, paints a picture of Watts as a moderate Calvinist who modified his inherited Puritan thought especially in areas of poetry, hymnody, and education. With regard to Watts' theological position Davis is primarily descriptive of his different works. However when he comes to draw together his findings he accuses Watts of inconsistency because of being an 'ingrained compromiser.' 3 Two key examples among many are that Watts exalts reason in his nonreligious works but depreciates it in religious ones, and that he is both fearful of the passion of enthusiasm but still tries to infuse such passion into religion. This portrait of Watts' inconsistency has gained credibility in the literature. ${ }^{4}$ It will be argued here that a

\footnotetext{
${ }^{1}$ Arthur Paul Davis, Isaac Watts: His Life and Works (London: Independant Press, 1948), Chapter 19. This is the UK publication; the American edition was published in 1943.

${ }^{2}$ Alan P. F. Sell, "Philosophy in the Eighteenth Century: Dissenting Academies of England and Wales," History of Universities XI (1992): 111.

${ }^{3}$ Davis, Watts, 222.

${ }^{4}$ For example John Hoyles, The Waning of the Renaissance, 1640-1740: Studies in the Thought and Poetry of Henry More, John Norris, and Isaac Watts (The Hague: Martinus Nijhoff, 1971), 150. Paul Ramsey, "Introduction," in Freedom of the Will by Jonathan Edwards (New Haven: Yale University Press, 1957), 91-92.
} 
closer examination of Watts' thought on reason and passion reveals why he adopted the variety of positions he did, and hence begins to remove the charge of 'inconsistency'.

John Hoyles reached a similar conclusion to Davis in his examination of Watts, focussing on his poetry. He presents Watts as a typical example of the English Enlightenment in that he always looked to cultivate a 'middle way' in each area. ${ }^{5}$ While there is a degree of truth to this conclusion it fails to look for underlying seams of thought which may give further explanation for the positions Watts took. It will be argued in this work that his view of reason and passion are such underlying seams.

Isabel Rivers has examined Watts specifically on the theme of passion showing how he continued a Puritan emphasis on affective religion. ${ }^{6}$ Watts is presented as someone trying to hold together the rational and evangelical sides of eighteenth century dissent, and so transmit his Puritan heritage to a new generation. This is a helpful starting point in seeing key themes in Watts and we will revisit and expand on Rivers' analysis.

Beyond the works mentioned there has been no in depth analysis of Watts' theological thought published. However he is commonly referred to in the literature on eighteenth century dissent. That is often with regard to views on toleration, the growth of rationalism, the rise of hymn singing, changes in education, or as a precursor to revival. In these various references he is commonly referred to as a moderate Calvinist, or as a 'Puritan'. As we will see such labels are not necessarily unreasonable but much greater clarity is needed.

Clarity is also needed because of divergent views of Watts. For example he has been presented as someone who was a 'devoted follower' of Locke in the primacy of reason ${ }^{7}$,

\footnotetext{
${ }^{5}$ Hoyles, Waning of the Renaissance, 150.

${ }^{6}$ Isabel Rivers, Reason, Grace and Sentiment: A Study of the Language of Religion and Ethics in England 1660-1780. Volume 1, Whichcote to Wesley (Cambridge: Cambridge University Press, 1991).

${ }^{7}$ Roy Porter, Enlightenment: Britain and the Making of the Modern World (London: Allen Lane, 2000), 68.
} 
but also that he wished to 'revive the zeal of the old Puritans. ${ }^{, 8}$ It is said that he regarded Whitefield as an 'enthusiastic fideist'", but also that he himself 'used the methods of enthusiastic conversion. ${ }^{10}$ These divergent views are similar to those highlighted as 'inconsistent' by Davis above. It will be argued here that these discrepancies stem from a lack of appreciation of Watts' actual position on the role of reason and the place of passion in religion.

As well as the broad theological issues of the day Watts also wrote on practical areas of ministry and the Christian life. There have been some investigations of Watts' thought on these topics such as prayer and he is mentioned in works on preaching. The most common of these practical areas examined is his renovation of the praise of the church, and we will introduce and examine these works at the appropriate point in our study.

However there has been very little work attempting to connect his more practical works with his underlying theology. For example his reform of hymnody has been closely examined but with relatively little discussion of how his view of passion drives this work, which we will see is significant. The same is true with regard to his views of preaching and prayer. Our main aim then is to both examine Watts' position on the foundational topics of reason and passion and to see how these both drive and shape his practical works. This will give a more coherent view of Watts as a whole and will explain some of his supposed 'inconsistencies'.

Watts' position on reason and passion is of particular interest because of the time in which he wrote. New currents of thought regarding these areas were taking place which had significant influence on the religion of the day. They led in turn to the deist and sentimentalist movements but also with profound effects on the mainstream church. Watts was very aware of these changes and responded to them in his writings. Harvey

\footnotetext{
${ }^{8}$ Joseph Figures, "Isaac Watts and his Position in the Eighteenth Century," Congregational Quarterly 35(1957): 344.

${ }^{9}$ W. Reginald Ward, Christianity under the Ancien Régime, 1648-1789 (Cambridge: Cambridge University Press, 1999), 143.

${ }^{10}$ Scott A. Gunn, "We Have Sat Out Ye Hearing of a Sermon": Manuscript Sermons in the James M. and Marie-Louise Osborn Collection," Yale University Library Gazette 71, no. 3/4 (1997): 149.
} 
comments that Watts 'shows a remarkable awareness of the main intellectual currents of his time. ${ }^{, 11}$ Watts came from a Puritan background and in many ways continued distinctive Puritan doctrines. However, not surprisingly, he adapted these in light of the new thinking of his day. What we will see is that is that Watts modified his received Puritan heritage on the key areas of reason and passion, and it is these modified positions which shape his practical works on the revival of religion.

\section{Biography and background}

The biographical details of Isaac Watts are readily available and a brief summary will suffice for our purposes. ${ }^{12}$ Watts grew up in Southampton in a dissenting family and his further education was at Thomas Rowe's dissenting academy in Stoke Newington. He worked first as a private tutor to the Hartopp family and then in 1699 became assistant minister to Isaac Chauncey at a congregational church meeting in Mark Lane. ${ }^{13} \mathrm{He}$ succeeded Chauncey as minister in 1702 . His ministry was interrupted by chronic illness and an assistant minister was appointed who later became a co-minister. $\mathrm{He}$ continued in this position until his death in 1748. From 1712 onwards he lived in various homes of the Abney family, his ministerial duties varying depending on his health.

Of particular interest to us is Watts' education at the Stoke Newington academy. ${ }^{14}$ Rowe was considered something of an innovator in introducing his students to what was called

\footnotetext{
${ }^{11}$ F. Brompton Harvey, "The Two Isaacs: Newton 1642-1727; Watts 1674-1748," London Quarterly and Holborn Review 174 (1949): 128.

${ }^{12}$ See Davis, Watts; David G. Fountain, Isaac Watts Remembered (Harpenden: Gospel Standard Baptist Trust, 1974); Thomas Wright, Issac Watts and Contemporary Hymn-Writers, vol. 3 (London: C. J. Farncombe \& Sons, 1914); Edwin Paxton Hood, Isaac Watts: his Life and Writings, his Homes and Friends (London: Religious Tract Society, 1875); Thomas Milner, The Life, Times and Correspondence of the Rev. Isaac Watts, D.D. (London: Simpkin and Marshall, 1834); Thomas D. D. Gibbons, Memoirs of Isaac Watts (London, 1780).

${ }^{13}$ For the background of congregationalism see Michael R. Watts, The Dissenters (Oxford: Clarendon Press, 1978); Geoffrey F. Nuttall, Beginnings of Nonconformity (London: James Clarke \& Co. Ltd, 1964).

${ }^{14}$ For discussion of this academy and dissenting academies in general see Herbert McLachlan, English Education under the Test Acts: Being the History of the Non-Comformist Academies, 1662-1820
} 
'free-philosophy', although Stewart points out that the same might be said of Rowe's predecessor. ${ }^{15}$ Rowe turned from some of the traditional text books, and is seen as pioneering the study of Locke. ${ }^{16}$ Watts' education then was in an atmosphere of new enquiry. Stewart points out that this involved:

...controlled freedom of belief, releasing the mind from what came to be perceived as religiously harmful influences. Outright freedom of belief would have seemed like opening it to harmful influences. ${ }^{17}$

This educational approach had a significant effect on Watts as is clear from a poem dedicated to Rowe entitled 'Free Philosophy'. It begins with decrying the traditional forms of education:

Custom, that tyranness of fools,

That leads the learned round the schools, In magic chains of forms and rules!

And then later praises Rowe:

I love thy gentle influence, Rowe, Thy gentle influence like the sun, Only dissolves the frozen snow, Then bids our thoughts like rivers flow, And choose the channels where they run. ${ }^{18}$

(Manchester Manchester University Press, 1931), 49-52. M. A. Stewart, Independency of the Mind in Early Dissent (London: Congregational Memorial Hall Trust, 2004). Alexander Gordon, Addresses, Biographical and Historical (London: The Lindsey Press, 1922). David L. Wykes, "The Contribution of the Dissenting Academy to the Emergence of Rational Dissent," in Enlightenment and Religion: Rational Dissent in Eighteenth-Century Britain, ed. Knud Haakonssen (Cambridge: Cambridge University Press, 1996).

15 Stewart, Independency, 28.

${ }^{16}$ Alan P. F. Sell, John Locke and the Eighteenth-Century Divines (Cardiff: University of Wales Press, 1997).

${ }^{17}$ Stewart, Independency, 34.

${ }^{18}$ Isaac Watts, The Works of the Late Reverend and Learned Isaac Watts, D.D. published by himself, and now collected into six volumes. Revised and corrected by D. Jennings, D.D. and the late P. Doddridge, 
Watts later comments on his learning from modern voices such as Descartes in the preface to his Philosophical Essays. He says:

If I can pretend to any freedom of thought in my little sphere of inquiry after truth, I must ascribe the original of it to my reading the first book of DesCartes's principles in the beginning of my studies, and the familiar comments which I heard on that work. That great man, in some of his writings, pointed out the road to true philosophy, by reason, and experiment, and mathematical science though he did not steddily pursue that track himself, in his own philosophising on corporeal things. ${ }^{19}$

Watts also mentions Gassendi, Bacon, Boyle, Locke and supremely Newton as those he honours in philosophy. He describes himself as of the 'eclectic sect' ${ }^{20}$ Sell comments on this eclecticism saying Watts wanted to keep elements of scholastic order, but was impressed with empiricism of Newton, was indebted to Locke, and retained a mindbody dualism from Descartes. ${ }^{21}$

This freedom of thought places Watts in the mainstream of the Enlightenment but he inherited a traditional Puritan orthodoxy and operated within a confessional establishment. $^{22}$ This introduces an inevitable tension: Watts engaged in free thought rather than slavery to traditional authorities, but where are the boundaries of orthodoxy $?^{23}$ Davis has called Watts a 'Puritan rebel' for his free thinking adjustments to inherited positions on such areas as education, praise and soteriology. ${ }^{24}$ Our examination focuses on Watts' view of reason and passion and how this shaped his

D.D. (London: T. and T. Longman, and J. Buckland; J. Oswald; J. Waugh; and J. Ward, 1753), 'Horae Lyricae', Volume 4, 393.

${ }^{19}$ Ibid., 'Philosophical Essays', Volume 5, 502.

${ }^{20}$ Ibid., 'Philosophical Essays', Volume 5, 501.

${ }^{21}$ Alan P. F. Sell, Philosophy, Dissent and Nonconformity (Cambridge: James Clarke, 2004), 37.

${ }^{22}$ For discussion of this tension with regard to Watts' reading see William E. Stephenson, "Isaac Watts's Education for the Dissenting Ministry, a New Document," Harvard Theological Review 61, no. 2 (1968): 278-81.

${ }^{23}$ For Watts' own reflections on this see Watts, Works, 'Reliquiae Juveniles', Volume 4, 552-54.

${ }^{24}$ Arthur Paul Davis, "Isaac Watts: Late Puritan Rebel," Journal of Religious Thought 13, no. 2 (1956). 
practical works; however in doing so we will note ways in which Watts allows 'freethinking' to modify his Puritan inheritance on these areas.

\section{Watts' influence and significance}

Watts' position is particularly worthy of study because of the enormous influence he had. This can be seen in several spheres, first in education. Rivers says of the reform of the dissenting academies that Watts 'exercised enormous influence through the great range of his writings, educational and philosophical as well as religious, many of them serving as academy textbooks. ${ }^{25}$

The most influential book was Watts' Logic (examined in chapter 2). Howell says it was 'one of the most popular textbooks of the next hundred years. ${ }^{, 26}$ It was used at Oxford and Cambridge and in the dissenting academies within a few years of publication as well as by tutors of variety of positions. ${ }^{27}$ It was in its twentieth edition by 1779 . Howell summarises: 'it is probably fair to say that in the English-speaking world more eighteenth century students and serious general readers learned their lessons about logic from Isaac Watts than from any other source. ${ }^{28}$ Similarly Watts' Improvement of the Mind was 'one of the best known textbooks of the late eighteenth and nineteenth centuries. $^{29}$

Secondly there is Watts' influence in reform of hymnody. Coffey says that Watts' Hymns was one of the "most popular and influential books of the eighteenth century,

\footnotetext{
${ }^{25}$ Rivers, Reason, Grace and Sentiment, Vol 1, 172.

${ }^{26}$ Wilbur Samuel Howell, Eighteenth Century British Logic and Rhetoric (Princeton: Princeton University Press, 1971), 331.

${ }^{27}$ Sell, Philosophy, 37. Davis, Watts, 87. Sell, "Dissenting Academies," 85-89.

${ }^{28}$ Howell, Logic, 342.

${ }^{29}$ Davis, Watts, 88. For more on publication of Watts' educational works see Marie Therese Whitehouse, "Isaac Watts and Philip Doddridge: Letters, Lectures and Lives and Eighteenth-Century Dissenting Culture" (University of London, 2011). Also see Samuel J. Rogal, "Isaac Watts' London printers, publishers, and booksellers (1700-1748)," Yale University Library Gazette (1972).
} 
and it mediated the affective piety of the Puritan tradition to later Protestants, especially Evangelicals. ${ }^{30}$ Marini's examination of publications concludes:

At ninety-nine editions, Isaac Watts's Psalms of David Imitated in the Language of the New Testament was the most frequently published work in eighteenth century America, followed by his Hymns and Spiritual Songs with seventy-eight printings. ${ }^{31}$

This is testified to not only by the numerous editions of these works but also the 'veritable school of Wattsian imitators' which soon followed. ${ }^{32}$ Just as popular were Watts' songs for children which judged by its editions was 'the world's most popular children's classic. ${ }^{33}$ In fact Parry says that nothing else that Watts wrote won him such fame. ${ }^{34}$

Watts was also a leading figure within dissent. He was asked to preach at significant events, gave advice and was looked to as a model for dissenting ministry. Parry points out that the reports at the time of Watts' death do not focus on his hymns, and concludes: 'It was not his hymns which made Watts a great national figure at the time of his death'; rather it was because he was the 'leading figure in London dissent. ${ }^{35}$

\footnotetext{
${ }^{30}$ John Coffey, "Puritan Legacies," in The Cambridge Companion to Puritanism ed. John Coffey and Paul Chang-Ha Lim (Cambridge: Cambridge University Press, 2008), 334.

${ }^{31}$ Stephen Marini, "Hymnody as History: Early Evangelical Hymns and the Recovery of American Popular Religion," Church History 71, no. 2 (2002): 279.

${ }^{32}$ Richard Arnold, The English Hymn: Studies in a Genre (New York: P. Lang, 1995), 40.

${ }^{33}$ Davis, Watts, 81.

${ }^{34}$ K. L. Parry, "Isaac Watts: Hymn-Writer and Divine," Listener (1948): 842.

${ }^{35}$ Ibid., 841. Such sermons include David Jennings, A Sermon Occasioned by the Death of the Late Reverend Isaac Watts D.D. Preached to the Church of which he was Pastor. December 11, 1748.
}

(London: J. Oswald and W. Dilly, 1749); Caleb Ashworth, Reflections on the Fall of a Great Man. A Sermon Preached to a Congregation of Protestant Dissenters at Daventry in Northamptonshire, On the Ocassion of the Death of the Late Reverend Isaac Watts D.D. (London: J. Waugh, 1749); John Milner, The Rest and Reward of Good Men at Death. A Sermon Preached at Peckham-Surry, Dec.11. 1748. (London: J. Noon, 1749). 
Nor was his influence restricted to Britain. We noted above the publishing of his hymns in America. This was also true for his educational and theological works and Watts himself had close links with Yale. ${ }^{36}$ He also influenced the continent with works being translated into German. ${ }^{37}$ Watts also had significant correspondence with the pietist group at Halle and various American ministers. This all formed part of his involvement in the attempts to revive the religion of the day. ${ }^{38}$

\section{Outline of study}

\subsection{Watts' setting: 'departed glory’}

We will give a fuller introduction to each area of discussion within the chapters that follow but a brief sketch here will help to frame our investigation. It has been commonplace to regard the early eighteenth century as a time of cool rational religion. Enlightenment thought had produced the view that Christianity 'was essentially attained and defended by pure reason and that its essence was expressed in morality and charity'; this had the effect of 'freezing the emotions and therefore public devotions. ${ }^{39}$

It has been recognised that this picture is something of an overstatement. For example the complexity of the relationship between enlightenment rationality and heterodoxy is highlighted by James Bradley and the ongoing significance of religion within enlightenment thought is shown by Donald Davie. ${ }^{40}$ However while the traditional view

\footnotetext{
${ }^{36}$ See Anne S. Pratt, Isaac Watts and his Gifts to Yale College (New Haven: Yale University Library, 1938).

${ }^{37}$ Geoffrey F. Nuttall, "Continental Pietism and the Evangelical Movement in Britain," in Pietismus und Reveil, ed. Johannes van den Berg and J. P. van Dooren (Leiden: E. J. Brill, 1978), 223-27.

${ }^{38}$ Susan O'Brien, "Eighteenth-Century Publishing Networks in the First Years of Transatlantic Evangelicalism," in Evangelicalism (Oxford: Oxford University Press, 1994).

${ }^{39}$ Horton Davies, Worship and Theology in England: Volume 3, From Watts and Wesley to Maurice, 1690-1850 (Princeton: Princeton University Press, 1961), 96. For an overview see Christopher Hill, The Century of Revolution, 1603-1714 (Walton-on-Thames: Nelson, 1980), Chapter 19.

${ }^{40}$ James Bradley, "The Changing Shape of Religious Ideas in Enlightened England," in Seeing Things Their Way: Intellectual History and the Return of Religion, ed. Alister Chapman, John Coffey, and Brad S. Gregory (Notre Dame, Ind.: University of Notre Dame Press, 2009). Donald Davie, A Gathered
} 
may be overstated it was not entirely wrong. Porter for example paints a picture in which the vitality of religion is mixed but where reason has made significant inroads. ${ }^{41}$ The ministers of the day certainly reported such concerns. ${ }^{42}$ In 1712 Daniel Defoe said that no one would dispute that dissent was in a 'declining and decaying posture', and makes clear this is not so much in terms of numbers as spiritual vigour. ${ }^{43}$ Rationalism appears to have played its part in this as well as the disadvantages of non-conformity. ${ }^{44}$

Watts himself comments on the advanced reason of his times:

...it must be acknowledged indeed, to the honour of the present age, that we have some pretenses above our predecessors, to freedom and justness of thought, to strength of reasoning, to clear ideas, to the generous principles of Christian charity.

But he laments:

....as for the savour of piety, and inward religion...spiritual mindedness, and zeal for God and for the good of souls; as to the spirit and power of evangelical ministrations, we may all complain, the glory of God is much departed from our Israel. ${ }^{45}$

Church: The Literature of the English Dissenting Interest, 1700-1930 (London: Routledge \& K. Paul, 1978).

${ }^{41}$ Porter, Enlightenment, Chapter 5.

${ }^{42}$ See for example, Strickland Gough, An Enquiry into the Causes of the Decay of the Dissenting Interest (London: J. Roberts, 1730), 40.

${ }^{43}$ Daniel Defoe, The Present State of the Parties in Great Britain: Particularly an Enquiry into the State of the Dissenters in England (London: J. Baker, 1712), 285. On decline and numerical strength see Watts, The Dissenters, Chapter 4.

${ }^{44}$ For further discussion on the situation of religion see J. C. D. Clark, English Society, 1660-1832: Religion, Ideology and Politics during the Ancien Regime (Cambridge: Cambridge University Press, 2000); Charles Gordon Bolam et al., The English Presbyterians: From Elizabethan Puritanism to Modern Unitarianism. (London: George Allen \& Unwin, 1968); Gordon Rupp, Religion in England 1688-1791, Oxford history of the Christian Church (Oxford: Clarendon Press, 1986); Robert Tudor Jones, Congregationalism in England, 1662-1962 (London: Independent Press, 1962); Bernard Manning, Essays in Orthodox Dissent (London: Independent Press, 1939).

${ }^{45}$ Watts, Works, 'Sermons', Volume 1, xxiii. 
Within dissent there was also the ongoing fear of the stigma of 'enthusiast', and a concomitant desire to present oneself as a reasonable and sober citizen. Other factors such as the relative freedom of the press and a fear of imposing creedal affirmation allowed heterodoxy to begin to express itself publicly. ${ }^{46}$ The overall result was a loss of zeal and the gradual decay of orthodoxy. ${ }^{47}$

As well as the rise and influence of rationalism the Enlightenment also brought an 'upwards evaluation of emotion in the eighteenth century known as the cult of sentiment. ${ }^{48}$ Hence Dixon says 'this was an age of passions and sentiments as much as it was an age of reason. ${ }^{49}$ Rather than passions being regarded as wholly negative, such that they required subduing and controlling, there was the revolutionary thought that some passions were innately good. This led to significant changes in thought regarding the role of passion in morality, religion and public life.

Hence both with regard to reason and passion the intellectual climate had changed with the result that significant questions were being asked of traditional Christian theology. As Hoppit summarises: 'it was not so much that God, Christ, or the Church, were less significant by 1727 , rather there was more uncertainty as to just what their significance was. $^{, 50}$

This uncertainty comes after the dominance of the Puritan theology of the seventeenth century. It has been shown how later Puritans began reframing their Reformed position in response to both the new intellectual climate, and the anti-Calvinist arguments of the

\footnotetext{
${ }^{46}$ Roland N. Stromberg, Religious Liberalism in Eighteenth-Century England (London: Oxford University Press, 1954), 5-8. Russell E. Richey, "From Puritanism to Unitarianism in England: A Study in Candour " Journal of the American Academy of Religion 41, no. 3 (1973).

${ }^{47}$ Watts, The Dissenters, Chapter 4. Rupp, Religion, Chapter 16.

${ }^{48}$ Michael Bell, Sentimentalism, Ethics and the Culture of Feeling (Basingstoke: Palgrave, 2000), 2.

49 Thomas Dixon, From Passions to Emotions: The Creation of a Secular Psychological Category (Cambridge: Cambridge University Press, 2003), 67.

${ }^{50}$ Julian Hoppit, A Land of Liberty? England, 1689-1727 (Oxford: Clarendon Press, 2000), 241.
} 
age. ${ }^{51}$ This led to a more moderate Calvinistic position among many later Puritans. This is the position which Watts inherited.

Our questions then are: what is Watts' position on the role of reason and passion? How does Watts respond to the new intellectual currents of his day on these topics? In what ways does this position modify the Calvinism Watts inherited? And, how then does Watts' position on these key topics shape his attempts to revive the religion of his day?

\subsection{Watts' aim: 'returning glory'}

We saw Watts' comment on the 'departed glory' of the church above. This is a common theme in his writings and his stated desire in many of his published works is a reversal of this, in bringing a 'returning glory' to the church of his day. In other words Watts' aim is the revival of religion which he sees as involving the reformation of the churches. We see this expressed in various places in his writings. For example Watts comments on a biblical event recorded in Acts chapter 2 which he sees as a model of church life. He says of it:

May these ears of mine be entertained with such devotion in public, such prayer, such preaching, and such praise! May these eyes behold such returning glory in the churches! ${ }^{52}$

Watts desires a reformation of three key elements: preaching, praise, and prayer. That these are central for him is seen in both his sermons and other works. ${ }^{53}$ Their centrality is also shown in the significance he attaches to them in the reformation of the church. ${ }^{54}$ When these areas are performed as Watts believed they can and should be, he says, 'Then shall religion look like itself, divine and heavenly, and shine in all the lustre it is

\footnotetext{
${ }^{51}$ Dewey D. Wallace, Shapers of English Calvinism, 1660-1714: Variety, Persistence, and Transformation (Oxford: Oxford University Press, 2011).

${ }^{52}$ Watts, Works, 'Improvement of Psalmody', Volume 4, 281.

${ }^{53}$ See for example a sermon on Christian Fellowship', ibid., 'Sermons', Volume 1, 831-40.

${ }^{54}$ See for example ibid., 'Humble Attempt', Volume 3, 33-38.
} 
capable of here on earth. ${ }^{, 55}$ Watts' published works were a central part of his aim in restoring this true piety to the church. ${ }^{56}$

We will therefore examine how Watts' practical works on revival relate to his understanding on the key theological issues of his day, reason and passion. The thesis is that his position on these foundational topics are formative for his practical works which attempt to revive religion. His views of reason and passion are the guiding principles for his views on the practice of preaching, praise, and prayer; and they produce the driving force behind his reformation of these areas. For Watts revival turns on right understanding of the place and role of reason and passion in the Christian life.

The central thesis then is internal to Watts' thought, to show the foundational nature of these topics to his practical works and hence the coherence of his theological position. To appreciate the position he adopts we will locate Watts within his own day, demonstrating where he fits within the theological and practical spectrums. We will also step back to see in what ways Watts is modifying a Puritan position on these topics.

We have seen that Watts came from a Puritan tradition but lived at a key transitional time. As Fairchild says:

His ministry and his writings form a link between the zeal of the seventeenth and the revived zeal of the later eighteenth century. He who had listened to the sermons of John Howe lived long enough to clasp the hands of Zinzendorf and Whitefield. Nor is this connection merely an accident of chronology: it implies a tenuous but unbroken continuity of doctrine and temperament. ${ }^{57}$

This quote suggests that Watts provides a connection between Puritanism and the evangelical revival, and so is a point of continuity i.e. he is a minority view through the

\footnotetext{
${ }^{55}$ Ibid., 'Prayer', Volume 3, 197.

${ }^{56}$ See the argument on this by Whitehouse, "Isaac Watts and Philip Doddridge", Chapter 3.

${ }^{57}$ Hoxie Neale Fairchild, Religious Trends in English Poetry (New York: Columbia University Press, 1939), 123.
} 
dark days until the light shone brightly again. ${ }^{58}$ However this is to see continuity where there is progression. Watts clearly had Puritan roots and speaks highly of his Puritan forbearers in a day when they were often held in disdain. For example:

Let us not be ashamed to distinguish our selves as the off-spring of the Puritans, and as protestant dissenters, who have learned of our fathers to pay a religious reverence to all that is holy. ${ }^{59}$

However, as we have seen, Watts was also one who was allowed to indulge in 'freethinking' and interacted with new thought of his day. Hence although Watts' aim is the revival of religion he did not see the answer as a simple return to Puritanism. Rather we will see him argue for a return to aspects of Puritanism but with significant modifications.

It is Watts' modified Puritan position on reason and passion that then functions as the driver for his practical works on preaching, praise, and prayer, and hence, we will see differences between him and many Puritans on these areas. This is the area that has been examined to some extent by Rivers, and in connection with his poetry by Hoyles. ${ }^{60} \mathrm{We}$ will introduce and interact with these works, as well as others, in the relevant chapters that follow.

So far we have referred to a 'Puritan position' as a single entity. The truth of course is that there were a wide range of Puritan positions both between individuals and over time. There is the associated complicating issue of definitions of Puritanism. ${ }^{61}$ In

\footnotetext{
58 The same point is made by Figures, "Watts," 344.

${ }^{59}$ Watts, Works, 'Humble Attempt', Volume 3, 76. Watts' commendation of Puritan authors is seen throughout his works. These are wide ranging but John Owen and Richard Baxter are the most commonly referenced. He also often tries to show how his position is supported by Puritan forefathers, for example on the Trinity, see ibid., 'Glory of Christ Jesus', Volume 6, 784.

${ }^{60}$ Rivers, Reason, Grace and Sentiment, Vol 1; Hoyles, Waning of the Renaissance.

${ }^{61}$ See John Coffey and Paul Chang-Ha Lim, "Introduction," in The Cambridge Companion to Puritanism, ed. John Coffey and Paul Chang-Ha Lim (Cambridge: Cambridge University Press, 2008), 1-7. Coffey and Lim define Puritanism as, "the name we give to a distinctive and particularly intense variety of early
} 
looking at how Watts modifies his Puritan inheritance it is beyond the scope of this work to provide any kind of comprehensive comparison. Even establishing a 'Puritan position' on these topics is a work of great magnitude. What will be attempted then are some illustrative comparisons or soundings between Watts and well recognised Puritan positions. We will compare him with some prominent Puritan names writing on similar topics and will focus on the seventeenth rather than sixteenth century. While giving such comparative soundings we will also rely on the secondary literature for generalised positions.

John Spurr has shown how later Stuart Puritanism was itself adapting and evolving. ${ }^{62}$ By the end of the seventeenth century this had resulted in the rise of moderate Calvinism which itself had changed in its view on the role of reason as well as other topics. ${ }^{63}$ Our examination of Watts will illustrate how that evolution continued into the eighteenth century.

Chapter 2 will examine Watts' position on the role of reason especially with regard to the work of John Locke. Similarly chapter 3 will examine his view of the place of the passions with reference to the sentimentalists of the era. Chapters 4, 5 and 6 then examine Watts' view of preaching, praise, and prayer respectively. In each of these we will give an overview of his position and then examine how his views on reason and passion play out in these practical areas. This is where we will see how foundational these views are to Watts and how they shape his practical works. We will compare Watts to his contemporaries so seeing the distinctive contribution he made. In all these areas we will give some comparative soundings to Puritan positions. These will illustrate both continuity and movement on these topics. A conclusion will draw together our observations and compare our findings with other pictures of Watts in the literature.

modern Reformed Protestantism which originated within the unique context of the Church of England but spilled out beyond it."

62 John Spurr, "Later Stuart Puritanism," in The Cambridge Companion to Puritanism, ed. John Coffey and Paul Chang-Ha Lim (Cambridge: Cambridge University Press, 2008).

${ }^{63}$ See for example David Field, Rigide Calvinisme in a Softer Dresse: The Moderate Presbyterianism of John Howe (1630-1705) (Edinburgh: Rutherford House, 2004), Chapter 1. 
In assessing Watts' thought the approach taken is that described by Skinner: 'to grasp their concepts, to follow their distinctions, to recover their beliefs and, so far as possible, to see things their way. ${ }^{64}$ This approach attempts to locate our subject in his day, understand his terms and appreciate what he was aiming to do in his writing. The present study follows the application by Chapman and others in applying this approach to religious thought. ${ }^{65}$ Hence we are attempting to understand what Watts believed he was doing in arguing for his position on reason and passion and how he was working towards the revival of religion.

\section{Watts' works}

The edition of Watts' works we will examine is that of 1753 which was prepared by Watts with a view to publication after his death, his manuscripts being entrusted to two friends to oversee publication. ${ }^{66}$ There were also two volumes of posthumous works published in 1779 containing sermons, hymns, poetry and letters. ${ }^{67}$ The poetry of this collection has been questioned as to its authenticity although the majority has been confirmed by stylistic and manuscript evidence to be by Watts. ${ }^{68}$ The focus for this study is Watts' prose works but we will occasionally quote hymns and poems to illustrate points.

We also examine appropriate correspondence. The majority of this is published in books and journals but unpublished manuscripts have also been examined. It has not been possible to examine all unpublished correspondence but given the nature of the

\footnotetext{
${ }^{64}$ Quentin Skinner, Visions of Politics, vol. 1 (Cambridge: Cambridge University Press, 2002), vii. ${ }^{65}$ Alister Chapman, John Coffey, and Brad S. Gregory, Seeing Things Their Way: Intellectual History and the Return of Religion (Notre Dame, Ind.: University of Notre Dame Press, 2009).

${ }^{66}$ For discussion see Whitehouse, "Isaac Watts and Philip Doddridge", 170-76.

${ }^{67}$ Isaac Watts, The Posthumous Works of the Late Learned and Reverend Isaac Watts, D.D. In two volumes. Compiled from papers in possession of his immediate successors: adjusted and published by a gentleman of the University of Cambridge (London: T. Becket and J. Bew, 1779).

${ }^{68}$ See the discussion by Davis, Watts, 239-42. Also see Alexander Lindsay, Index of English Literary Manuscripts 1700-1800, vol. 3, Part 4 (London: Mansell Publishing, 1997), 511.
} 
investigation Watts' letters have an illustrative and corroborative rather than a primary role. Manuscript copies of unpublished sermons have also been examined. ${ }^{69}$

Lindsay refers to a collection of works known as 'Wattiana: Manuscript Remains of the Rev Isaac Watts, DD, from the Library of Mr Joseph Parker, his Amanuensis'. He states that this is currently of unknown location. ${ }^{70}$ However a microfiche copy of this work exists at the British Library and this has been consulted. ${ }^{71}$ This work contains, among other pieces, unpublished sermons.

In a study of this kind one must of course be aware of the subject changing their thinking over time. In Watts' case there is a remarkably stable view on the topics examined which will be seen in the consistency between earlier and later works. However it is worth commenting on movements on other topics here.

Watts is known for an unorthodox position on the Trinity which is presumed to have developed during his career. However as Davis points out, while Watts continued to publish further works on the topic, his position was established by $1725 .{ }^{72}$ However earlier publications on the Trinity are not in contradiction to later ones; rather in his earlier works Watts shies away from an 'explication' of the Trinity, contenting himself with a positive assertion of the orthodox position. His later works may then not represent a movement but rather a greater confidence in revealing his hand. Similarly Watts is presumed to have moved to a more moderate form of Calvinism during his career. $^{73}$ The evidence for this is a letter at the start of his ministry stating that he agreed with John Owen on all the important matters of the faith which is then compared with his Baxterian position as presented in a later work. For our purposes we will simply use

\footnotetext{
${ }^{69}$ In particular this includes Lady Mary Abney, "Sermon Notes 1722-1723," in James Marshall and Marie-Louise Osborn Collection (New Haven: Beinecke Rare Book and Manuscript Library, Yale University).

${ }^{70}$ Lindsay, Index, 514.

${ }^{71}$ Isaac Watts, "Wattiana: Manuscript Remains of the Rev Isaac Watts, DD, from the Library of Mr Joseph Parker, his Amanuensis," (London: British Library).

${ }^{72}$ Davis, Watts, 114.

${ }^{73}$ Davis, "Puritan Rebel," 129-30.
} 
Watts' mature position on the Trinity and soteriology as an illustration of his view of the role of reason. ${ }^{74}$ On the primary issues of reason and passion which we will examine there is no evidence of significant change over time.

\footnotetext{
${ }^{74}$ See Chapter 2, section 5.2
} 


\section{Chapter 2 The Role of Reason}

\section{Introduction}

\subsection{Enlightenment reason in the early eighteenth century}

It has been acknowledged that the traditional description of the early eighteenth century as the 'age of reason' is misleading and the profoundly religious nature of this period has recognised. ${ }^{1}$ It is better thought of as a time in which reason became critical of itself and so was its coming of age. ${ }^{2}$ Key questions of the day were how faith and reason were to be linked, the relationship between natural and revealed religion, and the authority of the Bible versus the authority of reason. Linked with this was the question of evidence for the truth of Christianity, either external, such as prophecies or miracles, or internal, such as the work of the Spirit. ${ }^{3}$

New philosophical thought, bolstered by the successful science of the day, had resulted in an optimistic rationalism. This combined with a desire to distance oneself from what was seen as the enthusiastic irrationalism of the Puritan revolution. ${ }^{4}$ The authority of the Pope, the inner light of enthusiasm, and the rule of tradition had all been questioned and

\footnotetext{
${ }^{1}$ Alister Chapman, John Coffey, and Brad S. Gregory, Seeing Things Their Way: Intellectual History and the Return of Religion (Notre Dame, Ind.: University of Notre Dame Press, 2009); Jeremy Gregory, "Introduction: Transforming 'the Age of Reason' into 'an Age of Faiths': Or, Putting Religions and Beliefs (Back) into the Eighteenth Century," Journal for Eighteenth-Century Studies 32, no. 3 (2009). ${ }^{2}$ Michel Malherbe, "Reason," in The Cambridge History of Eighteenth-Century Philosophy, ed. Knud Haakonssen (Cambridge: Cambridge University Press, 2006), 319.

${ }^{3}$ Isabel Rivers, "Religion and Literature," in The Cambridge History of English Literature, 1660-1780, ed. John Richetti (Cambridge: Cambridge University Press, 2005), 448. Nicholas Hudson, Samuel
} Johnson and Eighteenth Century Thought (Oxford: Clarendon, 1988), Chapter 1.

${ }^{4}$ For example J. Spurr, "Rational Religion in Restoration England," Journal of the History of Ideas 49, no. 4 (1988); R. K. Webb, "The Emergence of Rational Dissent," in Enlightenment and Religion: Rational Dissent in Eighteenth-Century Britain, ed. Knud Haakonssen (Cambridge: Cambridge University Press, 1996). 
rejected in different ways; now the role of reason was elevated and rational defence of one's beliefs became the 'keynote of the age. ${ }^{5}$

Scripture was still seen as the source of authoritative revelation but it was Scripture as understood by reason. ${ }^{6}$ This is exemplified in groups such as the Cambridge Platonists for whom reason was the 'candle of the Lord' within mankind. Rather than a sharp polarity between reason and revelation as seen in many Puritans, this group emphasised the overlap between them. ${ }^{7}$ The authority of reason was seen in its fullest form in the deists who believed Scripture only contained a republication of natural religion, which could be understood from our use of reason. ${ }^{8}$ This is a group that we will see Watts strenuously opposing.

It is not that reason and the new science were antagonistic to religion. Rather Rosenblatt says that Enlightenment thought was seen as 'a valuable ally against the resurgence of religious fanaticism and sectarianism. ${ }^{9}$ It was held that reason proved revelation in Scripture, led to right understanding of Scripture, and so escaped authoritarianism and enthusiasm. ${ }^{10}$ It had become a commonplace by the end of the seventeenth century to say that while Scripture contained some truths that were above reason, it would teach nothing that was contrary to reason. However revelation being 'above reason' meant different things to different people. For some it meant that human reason could not have

\footnotetext{
${ }^{5}$ Stromberg, Religious Liberalism, 9.

${ }^{6}$ For background on the rise of reason see Peter Harrison, 'Religion' and the Religions in the English Enlightenment (Cambridge: Cambridge University Press, 1990), Chapters 1 and 2.

${ }^{7}$ Joseph M. Levine, "Latitudinarians, Neoplatonists and the Ancient Wisdom," in Philosophy, Science and Religion in England 1640-1700, ed. Richard Kroll, Richard Ashcraft, and Perez Zagorin (Cambridge: Cambridge University Press, 1992), 88-92.

${ }^{8}$ See discussion by A. B. Gerrish, "Natural and Revealed Religion," in The Cambridge History of Eighteenth-Century Philosophy, ed. Knud Haakonssen (Cambridge: Cambridge University Press, 2006).

${ }^{9}$ Helena Rosenblatt, "The Christian Enlightenment," in Enlightenment, Reawakening and Revolution 1660-1815, ed. J. Stewart Brown and Timothy Tackett (Cambridge: Cambridge University Press, 2006), 285. Although for a discussion of reason and atheism see John Redwood, Reason, Ridicule and Religion: The Age of Enlightenment in England, 1660-1750 (London: Thames and Hudson, 1976).

${ }^{10}$ Rosenblatt, "The Christian Enlightenment," 285.
} 
discovered such a truth but could understand it; for others reason could never fully comprehend God's divine wisdom. ${ }^{11}$

For most however reason was afforded an authority independent of Scripture: reason and revelation became complimentary, but with reason potentially holding the upper hand. ${ }^{12}$ This enchantment with reason contained as yet unforeseen pitfalls. ${ }^{13}$ As Sell says, it was 'only a matter of time before reason, instead of being regarded as revelation's handmaid became its master, and in some cases, its replacement. ${ }^{14}$ Similarly Cragg points out that while all groups appealed to the Bible, 'the Bible also was brought, though subtly, to the bar of reason. ${ }^{, 15} \mathrm{We}$ will see Watts interacting with these discussions and attempting to define the relationship between reason and revelation. While granting reason as significant a role as he can, Watts always tried to keep it subordinated to revelation.

Philosophical thought about logic had been mainly determined by Aristotelian categories until the rise of Ramism in the seventeenth century. This gave a simplified account of logic which was taken up by many including a large number within Puritan circles. ${ }^{16}$ Howell argues that while Ramus, Bacon, and Descartes prepared the way, John Locke then broke the dam of this old logic and opened the door to new enquiry in the light of experience, rather than deduction based on received maxims. ${ }^{17}$

\footnotetext{
${ }^{11}$ Jan W. Wojcik, Robert Boyle and the Limits of Reason (Cambridge: Cambridge University Press, 2002), 39.

${ }^{12}$ Willem J. van Asselt, Introduction to Reformed Scholasticism, ed. Joel R. Beeke and Jay T. Collier, Reformed Historical-Theological Studies (Grand Rapids: Reformation Heritage Books, 2011), Chapter 10.

${ }^{13}$ Stromberg, Religious Liberalism, 22-24.

${ }^{14}$ Alan P. F. Sell, Dissenting Thought and the Life of the Churches: Studies in an English Tradition (San Francisco: Mellen Research University Press, 1990), 78.

${ }^{15}$ G. R. Cragg, From Puritanism to the Age of Reason: A Study of Changes in Religious Thought within the Church of England 1660 - 1700 (Cambridge: Cambridge University Press, 1966), 8.

${ }^{16}$ van Asselt, Reformed Scholasticism, 92-94. Sell, Philosophy, 21-25.

${ }^{17}$ Howell, Logic, 279-80.
} 
Locke's thought clearly overshadowed all subsequent discussions of reason and revelation in the early eighteenth century. ${ }^{18}$ Malherbe says Locke 'offered a kind of map of human knowledge and a balanced criterion of truth. ${ }^{19}$ In an age looking for trusted points of reference such a map was gladly taken up. Despite the common labelling of Locke as an empiricist there is a strong rationalistic emphasis in his epistemology. ${ }^{20}$ Indeed it is said that one of Locke's main contributions was not so much specific philosophical ideas as simply fostering a spirit of enquiry based on use of reason. ${ }^{21}$

A fundamental issue within the debates of the day was how subjective beliefs related to objective knowledge. ${ }^{22}$ Locke's framework centring on our perception of agreement and disagreement of ideas allowed progress on this question, but he himself recognised the potential for subjective use of his system:

...if it be true that all knowledge lies only in the perception of the agreement or disagreement of our own ideas, the visions of the enthusiast and the reasonings of a sober man, will be equally certain... castles in the air will be as strongholds of truth. ${ }^{23}$

Locke's answer to this was to say that our knowledge is only real in so far as there is conformity between our ideas and the reality of things. However his criteria for establishing this conformity were themselves open to interpretation. These inherent ambiguities of Locke's system resulted in its being employed in different directions. This is illustrated by the contrasting works of the deist John Tolland and the Anglican bishop Joseph Butler, both of whom drew on Locke to entirely different ends. ${ }^{24}$

\footnotetext{
${ }^{18}$ Katharine M. Morsberger, "John Locke's 'An Essay Concerning Human Understanding': The Bible of the Enlightenment," Studies in Eighteenth Century Culture 25 (1996).

${ }^{19}$ Malherbe, "Reason," 322.

${ }^{20}$ Nicholas Wolterstorff, John Locke and the Ethics of Belief (Cambridge: Cambridge University Press, 1996), xv.

${ }^{21}$ Cragg, From Puritanism to the Age of Reason, Chapter 6.

${ }^{22}$ Manfred Kuehn, "Knowledge and Belief," in The Cambridge History of Eighteenth-Century

Philosophy, ed. Knud Haakonssen (Cambridge: Cambridge University Press, 2006), 390.

${ }^{23}$ John Locke, An Essay Concerning Human Understanding, ed. P. H. Nidditch (Oxford: Clarendon Press, 1975), IV.iv.1: 563.

${ }^{24}$ Malherbe, "Reason," 322-23.
} 


\subsection{Isaac Watts and John Locke}

Watts interacted with Locke many times in his works and wrote three poems about him. Thompson says that Watts' works 'are some of the most detailed and concentrated engagements with Lockean thought that can be found in the eighteenth century. ${ }^{, 25}$ Overall Watts has a high of Locke. In his introduction to Philosophical Essays he says:

He has proceeded to break our philosophical fetters, and to give us farther release from the bondage of ancient authorities and maxims. I acknowledge the light and satisfaction which I have derived from many of his works. ${ }^{26}$

Watts goes on to say he has followed Locke in many areas, especially in his work on civil government which left him 'charmed with truth.' With regard to Locke's Essay Concerning Human Understanding Watts takes an overall positive stance. He says:

His essay on the human understanding has diffused fairer light through the world in numerous areas of science and of human life. There are many admirable chapters in that book, and many truths in them, which are worthy of letters of gold. ${ }^{27}$

He disagrees with Locke on a variety of points such as the nature of substance ${ }^{28}$, and identity ${ }^{29}$, but on the whole is seen to follow Locke closely. Stewart says that Watts 'adapted Locke's epistemology to the needs of orthodox, if unsophisticated, belief., ${ }^{30}$

\footnotetext{
${ }^{25}$ Andrew C. Thompson, "What Isaac Watts and Philip Doddridge Were Doing When They Were Not Writing Hymns," Journal of the United Reformed Church History Society 6, no. 7 (2000): 479.

${ }^{26}$ Watts, Works, 'Philosophical Essays', Volume 5, 503.

${ }^{27}$ Ibid., 'Philosophical Essays', Volume 5, 503.

${ }^{28}$ John Yolton, John Locke and the Way of Ideas (London: Oxford University Press, 1956), 147-48.

${ }^{29}$ Sell, John Locke, 37. Also see Udo Thiel, "Religion and Material Metaphysics: Some Aspects of the Debate about the Resurrection of the Body in Eighteenth-Century Britain," in Philosophy and Religion in Enlightenment Britain, ed. Ruth Savage (Oxford: Oxford University Press, 2012).

${ }^{30}$ A. M. Stewart, "Revealed Religion: The British Debate," in The Cambridge History of EighteenthCentury Philosophy, ed. Knud Haakonssen (Cambridge: Cambridge University Press, 2006), 688.
} 
We will see that there are large areas of correspondence with Locke in Watts, and in this he takes on board much of the new logic of the Enlightenment. However we will also see that there are significant areas of disagreement on the potential and use of reason. These continue to sound notes from the previous theological era of the Puritans, and the result is a critical adaptation of Locke which avoids, and indeed attacks, the deist appropriation of Locke's thought.

\subsection{Watts' works relating to reason}

Watts wrote several works that dealt with the role of reason, its right and wrong use, and its possibilities and limitations. The main works will be briefly introduced here; others will be drawn on in discussing Watts' position including material from his sermons, hymns and poems.

Logic (1725): The scope of this work is well expressed in the extended title, 'The right use of reason in the inquiry after truth, with a variety of rules to guard against error in the affairs of religion and human life, as well as in the sciences.' The book is divided into four parts covering perceptions and ideas, judgement and propositions, syllogisms and disposition, and method. Watts is seen here to follow Locke's definitions and approach. $^{31}$

Caveat against Infidelity (1729): This is written specifically against deists and is to provide assurance and confidence to those tempted to doubt because of deist arguments. It is presented as a dialogue between different parties who are discussing the new and dangerous doctrine that has recently arisen among them.

The Strength and Weakness of Human Reason (1731): This is structured as a debate between a deist and an Anglican rector, with a mutual friend acting as moderator. The preface makes it clear that Watts disavows endorsing everything said by each participant but hopes that the discussion will cause pause for thought for those who believe revelation is unnecessary. As a result we will focus on the overall conclusions of the work rather than the precise detail.

\footnotetext{
${ }^{31}$ Davis, Watts, 86. Yolton, Way of Ideas, 206.
} 
Essay on the Freedom of Will (1732): This focuses on issues of liberty and necessity in decision making and argues for a version of liberty of indifference rather than liberty of spontaneity. Within the work though Watts explores how decision making occurs with the human psyche and hence the role of reason.

Philosophical Essays (1733): This collection of essays is on a variety of areas and interacts with Locke in a number of them. Those that concern us discuss innate ideas and Locke's essay on human understanding. ${ }^{32}$

Ruin and Recovery of Mankind (1740): This is an analysis of the doctrines of original sin and salvation through Jesus Christ. They are of interest to us because the aim of the work is not only to present the Scriptural teaching on these topics but to demonstrate how they are consonant with reason.

\section{An overview of the working of reason}

\subsection{Introduction}

We have already mentioned that Watts believed that he lived in a more enlightened age that had made great advances in its use of reason. We see this in his Logic where he says:

To believe in all things as our predecessors did, is the ready way to keep mankind in an everlasting state of infancy, and to lay an eternal bar against all the improvements of our reason and our happiness. ${ }^{33}$

Watts goes on to refer to the advances made by Bacon, Descartes, Copernicus, Newton, Locke and Boyle. His wider point is that we must not be enslaved by tradition but rather must use reason to develop our own convictions:

\footnotetext{
${ }^{32}$ Watts also interacts with Locke on identity, substance, and the material nature of the soul.

${ }^{33}$ Watts, Works, 'Logic', Volume 5, 111.
} 
We must all act according to the best of our own light, and the judgement of our own consciences, using the best advantages which providence hath given us, with an honest and impartial diligence to enquire and search out the truth: For every one of us must give an account of himself to God. ${ }^{34}$

In this we see Watts' 'enlightenment' side - impartial enquiry into truth - and his 'orthodox' side - living under the providence of and in the light of accountability to God.

As was standard in his age Watts sees God as having given us two 'springs of light', which are 'reason and revelation'. These two lights cannot contradict themselves or each another: 'There is not any one part of divine revelation which is really inconsistent with reason or with any other parts of revelation itself. ${ }^{35}$ This position is seen throughout his works where he regularly refers to truths that are known by both reason and the word of God.

Watts uses the term 'reason' in a broad sense: in Logic he says it is 'not confined to the mere faculty of reasoning or inferring one thing from another, but includes all the intellectual powers of man.' Watts understands the discipline of logic as the art of using our reason well in our discovery of the truth, and hence his view of the teaching of logic is the 'cultivation' of our reason. ${ }^{36}$ This cultivation is needed because since the fall reason is seen to be impaired, which we will explore below.

We should note then that Watts' broad definition of reason results in his using the same term in different ways. He speaks first of reason as a source of religious knowledge where our intellectual powers are applied to the world and human experience i.e. natural theology. It is in this arena that he discusses the limits of human reason in what it can tell us about God. He speaks secondly of reason as a methodological tool, for example applied to Scripture to show its right meaning and harmony. For Watts these are both examples of reason at work, simply applied to different sources of data. It is the first

\footnotetext{
${ }^{34}$ Ibid., 'Logic', Volume 5, 111.

${ }^{35}$ Ibid., 'Ruin and Recovery', Volume 6, 179.

${ }^{36}$ Ibid., 'Logic', Volume 5, 1-2.
} 
meaning that dominates the following discussion but we will notice examples of the second.

\subsection{Innate ideas}

Watts investigates innate ideas in one of his Philosophical Essays. The first section is entitled: 'the common notion well refuted by Mr Locke', in which he states that Locke has shown that there is no necessity from 'reason or religion' to believe that innate ideas exist. ${ }^{37}$ However the rest of the essay is spent showing how 'many simple ideas are innate in some sense.' Watts examines ideas, truths, and the rule of duty, and for each topic the argument runs along similar lines. Speaking of ideas he says:

...though they are not immediately, actually and explicitly impressed at once to the mind at its first union to the body; yet they may be called in some sense innate, for they seem to be given to the mind by a divine energy or law of union between soul and body appointed in the first creation of man. $^{38}$

These ideas come into action at the first instance when sensations give occasion to them. Watts sees this as part of how God has created humans to function and hence he says:

It is only God the author of our nature who really forms or creates these sensations and all these ideas of sensible qualities in a soul, united to a body, and he has appointed these ideas to arise when such particular impressions shall be made on the brain by sensible objects. ${ }^{39}$

It is clear that what Watts has in mind is more of a 'faculty' than an innate idea. Similarly in discussing in what sense truths may be innate he says that maxims like the law of non-contradiction are not inscribed on the mind in its creation but the 'very nature, make and frame of a rational mind is such that it cannot but judge according to such axioms as these.' So he says that these axioms:

\footnotetext{
${ }^{37}$ Ibid., 'Philosophical Essays', Volume 5, 546.

${ }^{38}$ Ibid., 'Philosophical Essays', Volume 5, 547.

${ }^{39}$ Ibid., 'Philosophical Essays', Volume 5, 547.
} 
....are so interwoven with the very constitution and nature of a reasoning being, that they are the constant principles of all its assent or dissent in particular enquiries: And in this sense perhaps they may be called innate. ${ }^{40}$

In arguing for these innate faculties Watts does not think Locke would object and indeed says that he speaks of innate principles like this himself. ${ }^{41}$ Spellman says that Locke had little time for the dispositional innatists as their ideas were so close to his own. $^{42}$

The same is true in morality where we are not born with moral propositions but:

....in the moulding of our souls God has given us faculties to discern the justness or fitness of such and such actions; and together with this discernment he has also inwrought into our souls some concomitant movements to judge aright, at least concerning the more general and obvious instances of virtue and vice, religion and morality. ${ }^{43}$

Elsewhere Watts says that this ability to make moral judgements 'is written in the hearts and consciences of mankind by the God of nature. ${ }^{44}$

A point of interest for us though is the variation between different realms of knowledge Watts believes can be gained by the use of such faculties. Watts draws a distinction between what can be known of moral duties as opposed to areas of natural philosophy. He sees the moral faculty described above as:

...much fainter and feebler than speculative principles, because they have been more corrupted by men, as more frequently contradicting their sensual

\footnotetext{
${ }^{40}$ Ibid., 'Philosophical Essays', Volume 5, 549.

${ }^{41}$ He refers the reader to Locke's Essay, II.viii.13, and II.iii.3. Davis does not seem to appreciate this point in saying Watts thought Locke's theory was 'untenable', Davis, Watts, 149.

${ }^{42}$ W. M. Spellman, John Locke and the Problem of Depravity (Oxford: Clarendon Press, 1988). See Locke's response to James Lowde on this topic, Locke, Essay, II.xxviii.11: 354-55.

${ }^{43}$ Watts, Works, 'Philosophical Essays', Volume 5, 550.

${ }^{44}$ Ibid., 'Sermons', Volume 1, 796.
} 
inclinations and vicious passions; where as in matters of speculation there is no such opposition in our natures. ${ }^{45}$

So while moral knowledge is possible it is a much weaker faculty because of the corruption of sin. We will see more of Watts' view of the effect of sin below.

\subsection{Words and ideas}

Watts follows Locke (and so in many ways Descartes ${ }^{46}$ ) in his view of the use of words and their relation to definite ideas. ${ }^{47}$ Locke distinguishes first between clear and obscure ideas. He says:

...our simple Ideas are clear, when they are such as the Objects themselves, from whence they were taken ... So far as they either want anything of that original Exactness, or have lost any of their first Freshness, and are, as it were, faded or tarnished by Time, so far are they obscure. ${ }^{48}$

Secondly he distinguishes between distinct and confused ideas:

... a distinct Idea is that wherein the Mind perceives a difference from all others; and a confused Idea is such an one, as it not sufficiently distinguishable from another, from which it ought to be different. ${ }^{49}$

Locke then repeatedly refers to the use of 'clear and distinct ideas'. This is linked to Locke's view of words which operate as signs of our ideas. ${ }^{50}$ In discussing the abuse of words Locke says that the 'first and most palpable abuse' is 'the using of Words,

\footnotetext{
${ }^{45}$ Ibid., 'Philosophical Essays', Volume 5, 546.

${ }^{46}$ See Hans Aarsleff, "Philosophy of Language," in The Cambridge History of Eighteenth-Century Philosophy, ed. Knud Haakonssen (Cambridge: Cambridge University Press, 2006), 453.

${ }^{47}$ For Locke's view of ideas see Vere Chappell, "Locke's Theory of Ideas," in The Cambridge Companion to Locke, ed. Vere Chappell (New York: Cambridge University Press, 1994).

${ }^{48}$ Locke, Essay, II.xxix.2: 363.

${ }^{49}$ Ibid., II.xxix.4:364.

${ }^{50}$ Ibid., III.i.2: 402. For Locke's view of representation see M. Thomas Lennon, "Locke on Ideas and Representation," in The Cambridge Companion to Locke's "Essay Concerning Human Understanding", ed. Lex Newman (Cambridge: Cambridge University Press, 2007).
} 
without clear and distinct Ideas. ${ }^{, 51}$ Hence Locke saw clear and distinct ideas and their right relation to words as fundamental to progress in knowledge ${ }^{52}$

These themes are clearly evident in Watts. In his Logic he echoes these sections of Locke's essay. For example:

The first rule is this, Seek after a clear and distinct conception of things as they are in their own nature, and do not content yourselves with obscure and confused ideas, where clearer are to be attained. ${ }^{53}$

This is then linked with the use of words: 'Have a care of making use of mere words, instead of ideas, that is, such words as have no meaning, no definition belonging to them. ${ }^{54}$ In Improvement of the Mind he advises young students: 'Do not content yourselves with mere words and names, lest your laboured improvements only amass a heap of unintelligible phrases, and you feed upon husks instead of kernels. ${ }^{, 55}$

The necessity of clear and distinct ideas and their link with words throughout his works is also seen in Watts' practical works. For example in his introduction to his Catechisms written for children he says that the business of the teacher is 'not merely to teach them words but things. ${ }^{56}$ He goes on to speak emphatically of what will happen if this is not observed and children begin to learn words without clear ideas:

...they will get into a habit of dealing in sounds instead of ideas, and of mistaking words for things, than which there is scare any thing more pernicious to the reason and understanding of a man; nor is there anything that tends more to corrupt and spoil the judgement in its early exercises. ${ }^{57}$

\footnotetext{
${ }^{51}$ Locke, Essay, III.x.2: 490.

${ }^{52}$ Ibid., IV.xii.6: 642.

${ }^{53}$ Watts, Works, 'Logic', Volume 5, 41.

${ }^{54}$ Ibid., 'Logic', Volume 5, 43.

${ }^{55}$ Ibid., 'Improvement of the Mind', Volum 5, 255.

${ }^{56}$ Ibid., 'Catechisms', Volume 3, 211.

${ }^{57}$ Ibid., 'Catechisms', Volume 3, 217.
} 
In discussing debated theological terrain Watts speaks of the advantages that would result from a clear use of language:

If we could but always confine every term to one certain determinate idea, we should gain and preserve much clearer ideas of things; we should make swifter and larger advances in knowledge; we should cut off a thousand occasions for mistake, and take away a multitude of controversies. ${ }^{58}$

Similarly in a letter to Boston minister Benjamin Colman, Watts comments on his controversial writings on the Trinity and says that his aim had been to 'introduce ideas as far as possible into the room of mere words and phrases. ${ }^{59}$

In later chapters we will see Watts' repeated application of this principle to the practical areas of preaching, praise and prayer. However later in this chapter we will also note some significant caveats which Watts introduces with regard to this principle.

\subsection{Reason, knowledge and will}

Watts clearly follows Locke in his general approach to reason and knowledge. We see this early in his life in an essay he wrote while at Rowe's academy which uses Locke's terminology of agreement of ideas. ${ }^{60}$ Later in his philosophical essays Watts quotes from and follows Locke closely on sensation as the origin of our ideas, on primary and secondary qualities of bodies, and on reflection. However he adds a third type of idea, that of abstraction, to Locke's sensation and reflection. ${ }^{61}$ This is not of great moment as Locke would seem to include this within his understanding of 'reflection'. ${ }^{62}$

This following of Locke is also seen in part two of Logic where Watts discusses the different ways in which 'truth is let into the mind. ${ }^{, 63}$ This section partially follows (and

\footnotetext{
${ }^{58}$ Ibid., 'Freedom of Will', Volume 6, 379.

${ }^{59}$ Isaac Watts, "Letters," Proceedings of the Massachusetts Historical Society 9 (1894): 340.

${ }^{60}$ Gibbons, Memoirs, 26.

${ }^{61}$ Watts, Works, 'Philosophical Essays', Volume 5, 536-45.

${ }^{62}$ Watts limits Locke's terms of 'sensation and reflexion' to what he calls 'observation'. Ibid., 'Improvement of the Mind', Volume 5, 196.

63 \{Watts, 1753 \#618@'Logic', Volume 5 , 88\}
} 
acknowledges Locke) in his view of sensation and reflection. Watts subdivides his categories further but does not stray away from Locke in overall sense. So Watts refers to 'consciousness' which relates to Locke's 'intuition'; 'reasoning' which relates to Locke's 'deduction', and faith which is on the basis of testimony of others as for Locke. ${ }^{64}$ We will examine the area of faith in relation to divine revelation in more detail below.

Watts' following of Locke ends in the third and fourth section of his Logic where Watts follows the path of the older logic in use of syllogisms and deductive thought which Locke was opposed to. Here Watts is following both Ramus and the Port-Royal Logic. ${ }^{65}$ However these sections receive less emphasis in the book as a whole. Hence Howell says that Watts wavered between the new and old methods: he spoke clearly about the advancement of learning that has come with new science and inductive logic, but continued some patterns of deductive argumentation. ${ }^{66}$ By comparison with earlier Puritan appropriation of Ramus then in Watts we find both continuity and discontinuity.

Watts sees our reason as ideally determining our decision making over our other faculties. In Ruin and Recovery asks whether it was unwise of God to attach our minds to a body and says it was not because:

...the innocent spirit or rational principle was formed in a state of power and dominion over all the appetites and passions that arise from flesh and blood; and had abundant capacity to resist all these temptations, while reason maintained its superior post in which it was created, and it did govern sense, and appetite and passion. ${ }^{67}$

\footnotetext{
${ }^{64}$ Locke, Essay, IV.xviii.2: 689.

${ }^{65}$ Howell, Logic, 343-45.

${ }^{66}$ Ibid., 336-40.

${ }^{67}$ Watts, Works, 'Ruin and Recovery', Volume 6, 227.
} 
Similarly in Freedom of Will Watts discusses our process of thought and decision making. ${ }^{68}$ He sees understanding gained by reason should act as the guide to the choices of the will:

The understanding, which perceives the fitness or unfitness, good or evil of things, should be a director or guide to the other power which is active, viz. the will, that it may regulate and determine it's actions wisely, and chuse and refuse objects proposed to it according to the fitness or unfitness, good or evil which is discovered by the understanding. ${ }^{69}$

But while the mind is such a director it is not 'an absolute Lord or Ruler', and it is up to the will to decide whether it will follow. ${ }^{70}$ The person of wisdom will always choose to follow the mind; however the mind can be led astray by poor judgements and in particular by the prejudices of the will. Hence:

We commit many mistakes about the fitness or goodness of things, by seeing them in a deceiving situation, in a false light, and under a disguise, by beholding things but in part and in an imperfect manner, by the numerous prejudices of many kinds that lead imperfect creatures astray in their judgement of things. ${ }^{71}$

Watts sees this scheme as giving grounds for condemnation of people for choosing wrongly, rewarding those who choose rightly, and escaping fatalism. ${ }^{72}$

Watts then sees the will as having a significant effect on the decisions of the mind which we will examine in more detail below. By contrast Locke sees the will as having

\footnotetext{
${ }^{68}$ It is worth noting that Watts was one of the main authors that Jonathan Edwards opposed in his famous work: Jonathan Edwards, Freedom of the Will, ed. Paul Ramsey (New Haven: Yale University Press, 1957), 89.

${ }^{69}$ Watts, Works, 'Freedom of Will', Volume 6, 385.

${ }^{70}$ Watts' position here on freedom of indifference is important for his soteriology in which he attempts to reconcile Calvinistic and Arminian positions.

${ }^{71}$ Watts, Works, 'Freedom of Will', Volume 6, 386.

${ }^{72}$ Sell, "Dissenting Academies," 108.
} 
no influence on the process of reason. ${ }^{73}$ Locke does say that the will is involved in deciding whether we will employ our reason; the will can choose to 'turn the eyes' to consider something or not. However once employed 'our Will hath no Power to determine the Knowledge of the Mind one way or other; that is only done by the Objects themselves, as far as they are clearly discovered.' And again: 'What a man sees, he cannot but see; and what he perceives, he cannot but know that he perceives. ${ }^{74}$ Hence for Locke the will decides what to examine, and how well to examine it, but it cannot affect the decisions reason makes. ${ }^{75}$ We will see the significant difference this makes below.

\section{The effect of sin on reason}

\subsection{Reason and the sinful body}

The comments above have already suggested something of Watts' view of the effect of sin on our reason. It is in essence a view where reason itself is unaffected but reason allied to a sinful body is fatally weakened. So for example in his Logic he says that reason would always lead us to truth (within its own compass) if it were used correctly. ${ }^{76}$ He goes on to discuss the 'Springs of False Judgement' which he calls 'The Doctrine of Prejudice' ${ }^{77}$ Several of the categories that Watts gives correspond with the sources of error and ignorance given by Locke in chapter 3 of Book IV of his Essay. Locke's list focuses on our inability to trace connections between our ideas, and our lack of ideas in the first place. Hence they have to do with the limitations of our reasoning ability rather than the effect of sinful desires on our reason. Locke finishes the Essay with a section on wrong assent or error and his four categories are again to with our limitations in reasoning. He does see that 'men's appetites and prevailing passions' can influence reasoning. However even here he believes that if only a man would take

\footnotetext{
${ }^{73}$ For an overview of Locke's view of decision making see V. C. Chappell, "John Locke on the Intellectual Basis of Sin," Journal of the History of Philosophy 32, no. 2 (1994).

${ }^{74}$ Locke, Essay, IV.xiii.2: 650-51.

${ }^{75}$ Wolterstorff, Locke and the Ethics of Belief, 105.

76 \{Watts, 1753 \#618@'Logic', Volume 5', 92\}

77 (Watts, 1753 \#618@'Logic', Volume 5, 92\}
} 
the time to suspend judgment and investigate properly then he could 'scarce refuse his assent' to the correct side. ${ }^{78}$

The result for Locke is that our passions only influence our reasoning by preventing us from exercising our reasoning powers as we should. This may include the desire not to reason because people might learn something which would not 'best suit their Prejudices, Lies and Designs' but this too keeps us from reasoning rather than distorting the reasoning process itself. ${ }^{79}$

While Watts agrees with Locke so far he makes a significant addition. For Watts the blame for error is laid most fully at the door of our sinful desires:

The various passions or affections of the mind are numerous and endless springs of prejudice. They disguise every object they converse with, and put their own colours upon it, and thus lead the judgement astray from truth. ${ }^{80}$

He mentions love, envy, anger, fear, and sorrow and says that detailing the evil influence of such passions would make 'a large volume.' This flows from his view of the interaction between reason and will above. Sin comes when we refuse to follow our reason but give way to 'allurements of sense or appetite of passion. ${ }^{, 81}$ And then 'reason opposed and beclouded by strong passion loses its clearness of judgement. ${ }^{, 82}$

Watts suggests that this rule of the passions over the mind is the explanation of Adam's sin: 'And perhaps this was the true spring of the fall of man from his state of innocence, and the entrance of sin into the world. ${ }^{, 83}$ For Watts Adam fell, not because of poor

\footnotetext{
${ }^{78}$ Locke, Essay, IV.xx. 12-15: 714-17.

${ }^{79}$ Ibid., IX.Xx.6: 710.

${ }^{80}$ \{Watts, 1753 \#618@'Logic', Volume 5', 100\}

${ }^{81}$ Ibid., 'Ruin and Recovery', Volume 6, 231.

${ }^{82}$ Ibid., 'Ruin and Recovery', Volume 6, 233.

${ }^{83}$ Ibid., 'Freedom of Will', Volume 6, 387.
} 
reasoning, but because good reasoning was overcome by bad passions. ${ }^{84}$ This is seen too in Watts' view of innate ideas (in their dispositional form). He thinks that if these principles were 'well improved' they would lead us to discern our duty and what is sin. However as it is:

The eye of the understanding is strangely blinded, and the judgment strangely perverted by the fall of man; we are led into false judgments of things by the corruptions of our minds, by the unhappy influence that present sensible things have over our whole nature, and the empire which appetite and evil passions have gotten over our superior faculties. ${ }^{85}$

Watts refers here to the 'corruption of our minds', however it is clear that this is because of the influence of our senses. This root of sin in the physical body is spelt out in Watts' essay The powers and contests of flesh and spirit. Here he speaks of sins of the mind apart from the physical body, such as pride or envy. However he locates the origin of sin in the flesh and says it continues to be the source of the majority of sins:

But the point which I propose to prove is this, that though there may be several sins that arise chiefly from the mind, yet there are multitudes of disorderly appetites, sinful inclinations and aversions, as well as violent immoderate tendencies towards lawful objects, seated in our animal nature, in our flesh and bloud, in this mortal part of our frame and composition, wherein we are a-kin to the beasts that perish; and it is by the senses, by these sensitive motions and ferments of flesh and bloud, that the human soul is most frequently led into temptation and $\sin .^{86}$

We can see examples of this in Watts' poetry. First in a poem on 'lewdness' (by which Watts means lustfulness) we read that: 'This brutal vice makes reason blind., 87 Secondly in a poem meditating on his sickness Watts writes:

\footnotetext{
${ }^{84}$ For similarities with Baxter's view of the fall see J. I. Packer, The Redemption and Restoration of Man in the Thought of Richard Baxter: A Study in Puritan Theology (Carlisle: Paternoster Press, 2003), 13839.

${ }^{85}$ Watts, Works, 'Philosophical Essays', Volume 5, 552.

${ }^{86}$ Ibid., 'Evangelical Discourses', Volume 2, 109.

${ }^{87}$ Ibid., 'Reliquiae Juveniles', Volume 4, 508.
} 
This flesh, this circling blood, these brutal powers

Made to obey, turn rebels to the mind,

Nor hear its laws. The engine rules the man. ${ }^{88}$

While this is in the context of sickness the influence of the body over the mind is clear. Hence Sell states that Watts pays more attention than Locke to the noetic effects of sin. ${ }^{89}$ We should note though that for Watts the 'noetic' effects are linked to the passions. While Watts makes general comments about our reason being in a state of darkness he locates the fault not in our minds but in our sinful body. ${ }^{90}$

\subsection{Three examples: original sin, education and conversion}

Watts' position on reason and sin can be further understood and illustrated by seeing its consequences for three other areas. The first is his explanation of original $\sin$. $\mathrm{He}$ believes the soul, which is where our reasoning powers lie, is created directly by God and so must be pure and innocent. Hence even in fallen man he sees reason beginning in a pure state. But, says Watts, reason is immature and so is easily led astray by the sinful passions of the flesh which we inherit from Adam:

These sinful ferments of the flesh, these irregular appetites, these motions of corrupt passion, so far as they are seated in the flesh and blood, are conveyed down from the original sinner, in greater or less degrees, to all his offspring in continual succession; and the soul, in it's infant state is perpetually impressed and allured by these vicious motions, appetites and passions of the flesh; and it as readily complies with those that are accounted criminal, as with those that are innocent. ${ }^{91}$

Secondly Watts' understanding of the effect of sin on our reason can be seen in his view of education. He comments on our propensity to error:

\footnotetext{
${ }^{88}$ Ibid., 'Reliquiae Juveniles', Volume 4, 524. Volume 4, p524.

${ }^{89}$ Sell, John Locke, 98.

${ }^{90}$ It is possible that Watts' position was influenced by the Cambridge Platonists. However they are not referenced in his works on this topic although Ralph Cudworth, for example, is mentioned elsewhere.

${ }^{91}$ Watts, Works, 'Ruin and Recovery', Volume 6, 242-43.
} 
There is still more of it owing to our original defection from God, and the foolish and evil dispositions that are found in fallen man; so that one great part of the design of logic is to guard us against the delusive influences of our meaner powers, to cure the mistakes of immature judgement, and to raise us in some measure from the ruins of our fall. ${ }^{92}$

Hence logic or right reasoning is seen as part of our recovery from the fall and hence part of God's redemptive purposes. So Davis says, 'To Watts, logic enabled fallen man to repair in some measure the ruins of his original defection. ${ }^{93}$

Thirdly we see Watts' position in his view of conversion, in which his understanding of the freedom of the will is also instrumental. He says of our inability to believe the gospel:

...the quality of this impotence [to believe] is best called moral, being seated chiefly in the will and affections, and not in any want of natural powers or faculties to perform what God requires. ${ }^{94}$

Hence conversion is by God illuminating the understanding so clearly that ungodly passions cannot override it any longer. So he says in footnote comment on Matthew 12:20:

Or it may be explained, he shall bring forth the judgement of the mind finally to a victory over the will and affections, which is a very near allusion, if not the true interpretation of the place. ${ }^{95}$

Watts believes this position overcomes the tension between human freedom and the need for divine grace: the gospel is presented by God in such superior light that a person will respond and yet this does not force their will to do so. Problems are avoided by,

\footnotetext{
${ }^{92}$ Ibid., 'Logic', Volume 5, 3.

93 Davis, Watts, 86.

${ }^{94}$ Watts, Works, 'Ruin and Recovery', Volume 6, 292.

${ }^{95}$ Ibid., 'Ruin and Recovery', Volume 6, 304.
} 
'Supposing the influence of the grace of God upon the soul of man to be only illuminative and persuasive, and yet finally efficacious and certain.' 96

\subsection{Consequent limits of reason}

While much of Locke's aim in his Essay was to reduce what was commonly assessed as 'knowledge' he still thought we could know enough to fulfil our duties to God and man. In commenting on how far short we fall from perfect knowledge he says that people should know that God has 'put within the reach of their Discovery the comfortable Provision for this Life and the Way that leads to a better. ${ }^{, 97}$

Despite an earlier confidence in his Essay Locke later admitted it was, 'too hard a task for unassisted Reason, to establish Morality in all its part upon its true foundations, ${ }^{98}$, and hence he spoke clearly of the need for revelation. ${ }^{99}$ However we must note that this is in regard to specific questions of morality and not whether we can have enough knowledge for salvation. In fact in addressing the question of what happens to those who never hear the gospel Locke turned to reason for his answer:

Yet God had, by the Light of Reason, revealed to all Mankind, who would make use of that Light, that he was Good and Merciful... He that made use of this Candle of the Lord, so far as to find out what was his Duty; could not miss to find also the way to Reconciliation and Forgiveness, when he had failed of his Duty. ${ }^{100}$

So Woolhouse summarises that for Locke we can 'know what we need to know for salvation. ${ }^{101}$ Similarly Sell says that "while there are echoes of Puritan thought in his writing, these stop short of any serious recognition of the possible epistemological

\footnotetext{
${ }^{96}$ Ibid., 'Freedom of Will', Volume 6, 397.

${ }^{97}$ Locke, Essay, I.i.5: 45.

98 John Locke, The Reasonableness of Christianity as Delivered in the Scriptures (Bristol: Thoemmes, 1997), 148.

${ }^{99}$ Spellman, Locke and Depravity, 137.

${ }^{100}$ Locke, Reasonableness, 140.

${ }^{101}$ Roger Woolhouse, "Locke's Theory of Knowledge," in The Cambridge Companion to Locke, ed. Vere Chappell (Cambridge: Cambridge University Press, 1994), 147.
} 
implications of the noetic effects of sin. ${ }^{102}$ This is summed up in Locke's comment on Romans 1:28 which speaks of the 'depraved mind' that results from sin: Locke simply says this refers to an 'unsearching and unjudicious mind', rather than to any serious malfunction of our reason. ${ }^{103}$

The sufficiency which Locke gave to reason contrasts with that given by Watts. Watts' work The Strength and Weakness of Human Reason is set up to investigate precisely the question as to whether reason is sufficient to guide mankind to future happiness i.e. salvation. The knowledge required for this is taken to be: knowledge of God and his attributes, mankind's obligation to God and other people, awareness of a future world with rewards and punishments, and awareness of the need for forgiveness (explicit knowledge of Christ is not seen as required). ${ }^{104}$

The possibility of reason discovering these different areas of knowledge is debated and there is a similar argument and conclusion in each case. Reason is seen to have the potential to bring such knowledge: 'mere human reason may be so cultivated and improved, without revelation, as to produce such fruits of knowledge as these are.' 105 However this potential is seen to be unrealised by humanity. It is a hypothetical sufficiency, or in the repeated words of the discussion it is 'little more than a speculative and abstract idea of sufficiency. ${ }^{106}$

The problem lies in the:

...right and due exercise of their reason on things moral, divine and spiritual and in things future and eternal, that though there be a natural sufficiency in human reason to find out such a religion as might save them, yet 'tis ten thousand to one, if they ever duly and rightly exercise it. ${ }^{107}$

\footnotetext{
102 Sell, John Locke, 64.

${ }^{103}$ John Locke, A Paraphrase and Notes on the Epistles of St. Paul (Oxford: Clarendon Press, 1987), preface.

${ }^{104}$ Watts, Works, 'Strength and Weakness', Volume 2, 211-21.

${ }^{105}$ Ibid., 'Strength and Weakness', Volume 2, 247.

${ }^{106}$ Ibid., 'Strength and Weakness', Volume 2, 248.

${ }^{107}$ Ibid., 'Strength and Weakness', Volume 2, 248.
} 
This renders reason 'practically insufficient. ${ }^{108}$ Reason is not insufficient because of any lack within it itself, rather the fault is laid at the feet of the appetites of the sinful body and the influence of a sinful society. This explanation is repeated throughout the work; here are two examples:

It is owing to their powerful prejudices, their evil moral habits, and their strong aversion to God and virtue, that they do not exercise their reasoning powers to the utmost of their capacity: And it is by this means they continue in darkness, guilt and death. ${ }^{109}$

... the glorious faculty of reason is so far overwhelmed and benighted by stupid ignorance, that it seeks not after the God who made them, and so wretchedly led captive by passion, appetite, and a thousand objects of sense, as scare ever to exert itself in any inquiries about the themes of self-denial and mortification, much less to find out these instances of virtue, or duty toward God or themselves. ${ }^{110}$

Hence reason gives enough light to condemn, but is not functional enough to give saving knowledge.

In his Logic Watts also briefly discusses whether reason can discover our moral duties. He says that in the pre-fall state man's reason may have been sufficient to discover God's moral will, but in our current sinful state it is 'by no means sufficient to find out all that is necessary to restore a sinful creature to the divine favour. ${ }^{111}$ As a result God has condescended to reveal what he requires.

The same conclusion is reached in a sermon on the knowledge of God by the light of nature. In this Watts argues that reason can indeed lead us to the knowledge of God that could be saving to us but that in practice it does not. It leads to a 'feeling after God in

\footnotetext{
${ }^{108}$ For a similar conclusion in a different work see ibid., 'The Redeemer and the Sanctifier', Volume 3, 773-74.

${ }^{109}$ Ibid., 'Strength and Weakness', Volume 2, 281.

${ }^{110}$ Ibid., 'Strength and Weakness', Volume 2, 233.

${ }^{111}$ Ibid., 'Logic', Volume 5, 128-29.
} 
the dark, than a sight of him in day light', and uncertainty and many mistakes about God result. ${ }^{112}$ So, despite its potential, the light of nature is so poor that knowing God through it is impossible. Once again the blame is laid at the door of our passions and appetites as well as heathen superstitions and traditions.

Again in notes on a sermon preached by Watts we read:

Whatever powers or capacity reason and the light of nature might have, to keep Adam in the love of God before the fall, to be sure, the poor remains of reason and the light of nature cannot find out ways to restore man to the love of God when he had fallen from it. ${ }^{113}$

In his work Orthodoxy and Charity Watts discusses the content of the gospel and how far it differs from natural religion. This is a different question from that set up in Strength and Weakness above. Here Watts is contrasting the glories of the gospel, such as the incarnation and atonement, from knowledge gained by reason. He says:

...it must needs be so far superior to all the dictates of the light of nature and to deserve those glorious characters which the apostle frequently gives it, viz. that it is the "wisdom of God in a mystery"... ${ }^{114}$

He goes on to draw on Paul's words that the gospel is a stumbling block to the Jews and foolishness to the Greeks. ${ }^{115}$ Here Watts draws the contrast between the gospel and the findings of human reason: the gospel must be 'something strange to their ears, and exceedingly different from their own opinions. ${ }^{, 16}$ This is Watts stressing the difference between the true gospel and the republication of the light of nature of the deists.

This position is then seen in Watts' hymns. For example a hymn based on Jesus' words in Luke 10:21-22 is entitled, 'The humble enlightened, and carnal reason humbled.' It

\footnotetext{
${ }^{112}$ Ibid., 'Sermons', Volume 1, 760.

${ }^{113}$ Abney, "Sermon Notes," 47.

${ }^{114}$ Watts, Works, 'Orthodoxy and Charity', Volume 3, 575.

115 This is a reference to 1 Corinthians chapter 1.

${ }^{116}$ Watts, Works, 'Orthodoxy and Charity', Volume 3, 576.
} 
speaks of those who are 'babes in knowledge' understanding the gospel. For others however:

But all this glory lies conceal'd

From men of prudence and of wit; ${ }^{117}$

The prince of darkness blinds their eyes;

and their own pride resists the light. ${ }^{118}$

The next hymn, based on the same verse, repeats the theme:

The myst'ries of redeeming grace

Are hidden from the wise,

While pride and carnal reas'nings join

To swell and blind their eyes. ${ }^{119}$

We should notice that Watts refers to 'carnal' reasoning, presumably to distinguish it from godly reasoning. In this Watts echoes older distinctions between right reason which is dependent on prevenient grace, and ungodly reasoning. ${ }^{120}$ However this is not a distinction developed by Watts; rather his focus is simply on the limitations of reason and the need for God to sovereignly reveal himself. Hence for Watts reason has great potential in allowing us to know God and our duties before him, but in practice it will never fulfil it.

\section{Reason and revelation}

\subsection{Reason evaluating revelation}

With his view of the limitations of reason Watts emphasises the necessity of revelation.

But in receiving God's revelation reason is not laid aside. He says in his Logic of revelation:

\footnotetext{
${ }^{117}$ Use of 'wit' here refers to ungodly use of reason.

${ }^{118}$ Watts, Works, 'Hymns', Volume 4, 155.

${ }^{119}$ Ibid., 'Hymns', Volume 4, 155. For a similar theme in Watts' poetry see 'The Infinite', ibid., 'Horae Lyricae', Volume 4, 354.

${ }^{120}$ Michael Heyd, "Be Sober and Reasonable": The Critique of Enthusiasm in the Seventeenth and Early Eighteenth Centuries (Leiden: Brill, 1995), 181.
} 
...though here our reason must be used both to find out the true meaning of God in his word, and to derive just inferences from what God has written, as well as to judge of the credentials whereby divine testimony is distinguished from mere human testimony, or from imposture. ${ }^{121}$

This is now the use of reason as a methodological tool applied to Scripture. There is great similarity with Locke's position on reason's role in both understanding and assessing revelation. ${ }^{122}$ We will briefly examine these two elements. Watts sees the role of reason first in understanding God's word. For example in his annotations on a book discussing reason Watts writes:

In this matter reason is the eye, true religion is the object: all other helps, divine and human, are as the light, as spectacles, etc. Now it is impossible to see with anything but our own eyes, i.e. our reason. Yet a clear light is also necessary, without which our eye cannot see the object, nor our reason find out the true religion. ${ }^{123}$

Hence reason plays a foundational part in our understanding of revelation, but requires divine aid. Later Watts says that reason must be used in bringing together the different elements of revelation to see their consistency:

...the exercise of our reasoning powers is very necessary to assist us, not only in the understanding of the several parts of revelation, but in reconciling them to each other as well as to the dictates of right reason. It is our reason which shews us this blessed harmony. ${ }^{124}$

While revelation will never contradict right reason Watts does believe, again with Locke, that revelation can 'rise above, or go beyond our reason. ${ }^{, 125}$ This opens up a tension for Watts which we will explore further below.

\footnotetext{
${ }^{121}$ Watts, Works, 'Logic', Volume 5, 120.

${ }^{122}$ See Locke, Essay, IV.xviii.

${ }^{123}$ Milner, Watts, 125. The book being annotated was M. Clifford, A Treatise of Humane Reason

(London: Henry Brome, 1675).

${ }^{124}$ Watts, Works, 'Ruin and Recovery', Volume 6, 180.

${ }^{125}$ Ibid., 'Logic', Volume 5, 120.
} 
Secondly with regard to reason evaluating the evidence for revelation Watts says:

Reason demands us to believe whatsoever divine revelation dictates: for God is perfectly wise and cannot be deceived; he is faithful and good and will not deceive his creatures: and when reason has found out the certain marks or credentials of divine testimony to belong to any proposition, there remains then no farther inquiry to be made, but only to find out the true sense and meaning of that which God has revealed, for reason itself demands the belief of it. ${ }^{126}$

So reason allows us to identify revelation. This leads Watts to be able to say in one of his appeals to deists that 'the light of nature, which the deist professes to take for his guide, if duly followed, will certainly lead him to believe the gospel. ${ }^{, 127} \mathrm{He}$ means that they will become convinced of the evidences God has given and so pay right attention to his revelation. ${ }^{128}$ Hence he writes in a letter to fellow minister Samuel Say: 'Reason honestly pursuing Truth will find sufficient evidence for the Christian and Jewish Revelation. ${ }^{129}$ Similarly he says in a sermon on 'faith without sight':

God has given us rational faculties and requires the exercise of them in religious concerns, and he has laid down such grounds for faith in all ages as must approve itself unto reason. ${ }^{130}$

In this Watts is employing a Lockean framework. Locke argued that acceptance of any proposition should be either based on its being discovered by reason, or by reason establishing its credentials. For the later such credentials meant God's testimony given by the miracles in Scripture. ${ }^{131}$ To deny the role of reason in these ways would lead to certain error:

\footnotetext{
${ }^{126}$ Ibid., 'Logic', Volume 5, 134.

${ }^{127}$ Ibid., 'Caveat against Infidelity', Volume 2, 502.

${ }^{128}$ Watts makes the same point elsewhere: ibid., 'Improvement of the Mind', Volume 5, 294-95, 336-37.

${ }^{129}$ Isaac Watts, "Letter to Samuel Say, 29 July 1732," (London: Dr Williams's Library, 1732).

${ }^{130}$ Watts, "Wattiana," 'Blessedness of Faith without Sight', 209.

${ }^{131}$ Wolterstorff, Locke and the Ethics of Belief, 131-33.
} 
To talk of any other light in the Understanding is to put ourselves in the dark, or in the power of the Prince of Darkness, and by our own consent, to give ourselves up to Delusion to believe a Lie. ${ }^{132}$

This is the context of his famous statement, 'Reason must be our last Judge and Guide in every Thing. ${ }^{133}$ It should be noted that this maxim does not rule out revelation for Locke, but rather guards what is considered revelation. Watts' approach agrees with this and so he argues that Christians should acquaint themselves with reasons for believing the gospel such as prophecies and miracles, as well as other arguments. He says:

Endeavour to furnish your minds with such arguments as will justify your own conscience in the belief of the gospel, and will firmly support your profession and practice of it as rational creatures. God requires that a creature of reason should be a reasonable worshipper. ${ }^{134}$

In this Watts is siding firmly with the reasonable spirit of his age and is at his most Lockean. However we will see later that Watts also utilises this framework in a different way to Locke.

\subsection{Revelation and faith}

Watts makes similar distinctions to Locke in describing two categories of revelation.

First God can and does reveal himself directly to people which Watts calls 'inspiration'. This relates to Locke's category of 'original revelation'. It is, says Watts:

When such an overpowering impression of any proposition is made upon the mind by God himself, that gives a convincing and indubitable evidence of the truth and divinity of it; so were the apostles and the prophets inspired. $^{135}$

\footnotetext{
${ }^{132}$ Locke, Essay, IV.xix.13: 703.

${ }^{133}$ Ibid., IV.xix.14: 704.

${ }^{134}$ Watts, Works, 'Caveat against Infidelity', Volume 2, 521.

${ }^{135}$ Ibid., 'Logic', Volume 5, 91.
} 
Watts differs from Locke here though in that he is content for the individual to be convinced of the divine origin of this revelation with no external authentication. Locke had criticised enthusiasts whose position he characterises as saying:

This Light from Heaven is strong, clear and pure, carries its own Demonstration with it, and we may as rationally take a Glow-worme to assist us to discover the Sun, as to examine the celestial Ray by our dim Candle, Reason. ${ }^{136}$

For Locke there always had to be evidence that was external to the person such as miracles ${ }^{137}$, whereas for Watts the overwhelming nature of the revelation is its own evidence. Watts says of the recipient in question:

He is under a superior heavenly impression, light and evidence, whereby he is assured that God reveals it. This is the most eminent kind of supernatural certainty. ${ }^{138}$

Secondly Watts sees that this revelation can be communicated to others which corresponds to Locke's category of 'traditional revelation'. Watts follows Locke in the way he speaks: 'this sort of knowledge is generally called faith; that is, the believing of any proposition upon the authority of those that relate it. ${ }^{, 139}$ He goes on to speak of the greater strength of belief depending on the credibility of the witness and so follows Locke in his view of probability. ${ }^{140}$

Further Watts agrees with Locke that this faith in the testimony of another cannot be done 'except by some antecedent or consequent prophecies or miracles, or some public appearances more than human. ${ }^{, 141}$ Without such external evidence God's direct

\footnotetext{
${ }^{136}$ Locke, Essay, IV.xix.8: 700.

${ }^{137}$ Ibid., IV.xix.14-15. Locke did allow that God might reveal himself without such authenticating signs but limits what can be known to the content of Scripture or that which could be discovered by reason (IV.xix.16).

${ }^{138}$ Watts, Works, 'Logic', Volume 5, 91.

${ }^{139}$ Ibid., 'Evangelical Discourses', Volume 2, 69.

${ }^{140}$ Locke, Essay, IX.xvi.

${ }^{141}$ Watts, Works, 'Logic', Volume 5, 161.
} 
inspiration can be convincing for the individual but should not be enforced on others.

We see a worked example of this in Watts' comments on the ministry of George

Whitefield. He says that he views Whitefield's extraordinary stamina in preaching for as long and as frequently as he did as a sign of God's endorsement of his ministry. It is 'the most divine, sensible evidence of an extraordinary call that I could find.'142 However Watts reproached Whitefield for some of his claims and prophecies. He questioned Whitefield about them and records his conversation as follows:

He owns that he can give me no sufficient proof of his being called to any extra-ordinary ministration, nor of the prophectical speeches that are sometimes found in his diarys, but he tells me that he has some inward sensations of particular impulses which have so often been fulfilled to him that he knows they are divine, but he owns these are such evidences as will not convince another person. ${ }^{143}$

Despite these similarities with Locke, Watts differs in his view of the certainty of knowledge gained by others through revelation. This is an area where Locke is seen to be somewhat ambivalent. Locke draws a sharp distinction between knowledge and faith: they rest on different foundations and have correspondingly different certainties. Faith, by his definition, cannot be completely certain; if it did it would become knowledge. So Locke wrote in a letter to Stillingfleet:

Faith stands by itself, and upon grounds of its own; nor can be removed from them, and placed on those of knowledge. Their grounds are so far from being the same, or having anything in common, that when it is brought to certainty, faith is destroyed; it is knowledge then, and faith no longer. ${ }^{144}$

\footnotetext{
${ }^{142}$ Watts, "Letters," 375.

143 Ibid., 374-75.

${ }^{144}$ John Locke, An Essay Concerning Human Understanding: Abridged and Edited, ed. Kenneth Winkler (Indianapolis, Ind.: Hackett Pub. Co., 1996), 355.
} 
Hence Jolley comments that, 'For Locke knowledge is a mental act or state that logically excludes believing., ${ }^{145}$ Locke's ambivalence comes in his statement as to how sure we can be in divine revelation. He says the testimony of revelation gives assurance beyond doubt and goes on that it:

...absolutely determines our Minds, and as perfectly excludes all wavering as our Knowledge it self; and we may as well doubt of our own Being, as we can, whether any revelation from GOD be true. ${ }^{146}$

Despite this reassurance, for Locke, reason remains supreme. Jolly argues that this is shown in two ways. ${ }^{147}$ First Locke insists that whatever revelation may communicate, it cannot convey a new simple idea as these must be communicated in language which is limited to expressing the simple ideas we have from sensation and reflection. Hence while people such as the apostle Paul may well have had ineffable experiences of God they cannot communicate them to us. Secondly Locke argues that when something is known through both reason and revelation, it is more certain through reason. ${ }^{148}$ Ayres summarises that Locke seeks to "clips the wings of revelation by subordinating it to "reason"., 149

Watts' system does not lead him into such a position. He simply states that the certainty of a proposition turns only on the certainty of the evidence, rather than on the mechanism by which it is known. Hence he can say anything we know because of 'divine faith' (that is faith in divine revelation) is utterly certain. ${ }^{150}$ For example:

\footnotetext{
${ }^{145}$ Nicholas Jolley, "Locke on Faith and Reason," in The Cambridge Companion to Locke's "Essay Concerning Human Understanding", ed. Lex Newman (Cambridge: Cambridge University Press, 2007), 438.

${ }^{146}$ Locke, Essay, IV.xvi.14: 667.

147 Jolley, "Faith and Reason," 444-45.

${ }^{148}$ See also discussion on this point by Wolterstorff, Locke and the Ethics of Belief, 126-31.

${ }^{149}$ Michael Ayers, Locke (London: Routledge, 1991), 121.

${ }^{150}$ Watts, Works, 'Logic', Volume 5, 162.
} 
When God reveals anything to us this gives us the evidence of divine faith ... [this] being founded on the word of God, arises to an absolute and infallible assurance... This is called supernatural certainty. ${ }^{, 151}$

For Watts, says Stewart, nothing is more certain than Christian revelation. ${ }^{152}$ This means that there is no 'trumping' of faith by reason for Watts. On the contrary Watts says it is revelation 'to which I intirely submit my faith and practice. ${ }^{153}$

\subsection{The superiority of revelation}

Watts' view of the superiority of revelation is an obvious conclusion from what we have seen so far: he believes reason is blinded because of the effect of sin, whereas revelation is clear and powerful. This is seen repeatedly in his writings; for example:

...the revelation of God in an illustrious manner supplies the deficiencies of our reason, and enlightens our natural darkness in the knowledge of divine things... ${ }^{154}$

His position is summarised in some of his hymns, especially four hymns based on Psalm 19 which itself compares revelation in nature and Scripture. These hymns emphasise the superiority of God's word over nature in the clarity of revelation. ${ }^{155}$ So he says, the heavens declare God's glory, but in Scripture, 'We read thy name in fairer lines'. There is also a contrast in content: nature reveals God's power and glory, but the word reveals God's grace and forgiveness. We see the same contrasts drawn in one of Watts' divine songs for children entitled The Excellency of the Bible. ${ }^{156}$

We see the same in Watts' hymns on general themes. A communion hymn speaks of how God reveals himself in nature, but only reveals his grace in the cross:

\footnotetext{
${ }^{151}$ Ibid., 'Logic', Volume 5, 90.

${ }^{152}$ Stewart, "Revealed Religion," 688.

${ }^{153}$ Watts, Works, 'Ruin and Recovery', Volume 6, 319.

${ }^{154}$ Ibid., 'Ruin and Recovery', Volume 6, 180.

${ }^{155}$ Ibid., 'Psalms', Volume 4, 19-21.

${ }^{156}$ Ibid., 'Divine and Moral Songs', Volume 4, 299.
} 
Nature with open volume stands,

To spread her Maker's praise abroad,

And ev'ry labour of his hands,

Shews something worthy of a God:

But in the grace that rescu'd man,

His brightest form of glory shines;

Here, on the cross, 'tis fairest drawn

In precious blood and crimson lines. ${ }^{157}$

The next stanza begins, 'Here his whole name appears complete', showing that the revelation of God is only filled out by revelation through Jesus Christ. We also see the superiority of revelation in a poem Watts wrote on John Locke's annotations on the New Testament. Watts speaks of how reason can learn some truths, but then goes on to speak of reason's inability to discover core elements of Christian doctrine which God reveals to us:

Reason could scare sustain to see

Th' almighty One, the eternal Three,

Or bear the infant deity;

Scare could her pride descend to own

Her Maker stooping from his throne,

And drest in glories so unknown.

A ransom'd world, a bleeding God,

And heav'n appeas'd with flowing blood,

Were themes too painful to be understood. ${ }^{158}$

\section{Reason and Christian doctrine}

\subsection{The reasonableness of Christian doctrine}

We have seen Watts' understanding of reason assessing revelation. Here we note that Watts was also emphatic on the reasonableness of the content of revelation. First we see that Watts views the two sources of knowledge, reason and revelation, as overlapping: he believes that the content of revelation includes everything that reason can teach us

\footnotetext{
${ }^{157}$ Ibid., 'Hymns', Volume 4, 261.

${ }^{158}$ Ibid., 'Horae Lyricae', Volume 4, 397.
} 
about God. A consequence is that, for him, denying reason is to deny Christianity. So the main apologist in The Redeemer and the Sanctifier says:

I acknowledge indeed, and I glory in it, that the gospel which I find in the new testament contains every article of natural religion, and includes in it every thing that reason can teach us about God or virtue. The man who renounces any one point of the religion of reason, so far renounces Christianity also; for the doctrine of the blessed Jesus comprehends every part of it, and confirms it forever. ${ }^{159}$

Similarly in A Caveat Against Infidelity Watts argues with deists that the 'religion of nature is all included in the religion of Christ. ${ }^{, 160}$

More than this overlap Watts believed in the reasonability of the content of revelation. One key aim in his writings was to defend the reasonableness of the central points of Christian doctrine. So the subtitle of Ruin and Recovery, which explores original sin and salvation, is: 'An Attempt to vindicate the SCRIPTURAL ACCOUNT of these great events upon the plain principles of REASON.'

This emphasis on Scripture and reason, with the vindication of the former by the later, runs throughout Watts' works. In his Improvement of the Mind he acknowledges that those who inquire into reason are often counted as foes to orthodoxy; but for Watts if such enquiry is conducted correctly then reason will only vindicate the faith. ${ }^{161}$ So Hoyles says, 'Watts never tired of relating revealed religion to natural religion in his attempt to establish solid grounds for piety., 162

As well as showing the consistency of revelation to natural theology, Watts also uses reason in the methodological sense to show the harmony and consistency of revelation itself. This is the purpose of his Harmony of Religion where he says he has given:

\footnotetext{
${ }^{159}$ Ibid., 'Redeemer and Sanctifier', Volume 3, 734.

${ }^{160}$ Ibid., 'Caveat against Infidelity', Volume 2, 517. This is seen in other works as well such as Harmony of Religion.

${ }^{161}$ Ibid., 'Improvement of the Mind', Volume 5, 288-89.

${ }^{162}$ Hoyles, Waning of the Renaissance, 184.
} 
... a compendious arrangement of the discoveries of the grace of God and the duty of man, in such an order as God has prescribed them, and such as may best show their consistence, their reasonableness and equity. ${ }^{163}$

This emphasis on the reasonableness of the faith is seen in his sermons as well. Within a series of sermons on Romans 1:16 (where the apostle Paul speaks of not being ashamed of the gospel) Watts says:

I am not ashamed to believe this gospel as a man. My rational powers give me no secret reproaches. My understanding and judgment do not reprove and check my faith. ... My own reason approves it, and justifies me in the persuasion and belief of a gospel such as this. ${ }^{164}$

Similarly in The Redeemer and the Sanctifier, while insisting that our reason is unable to make out the content of revelation, Watts suggests that once it is known it is perfectly consistent with our reason:

It is granted, indeed, that the reason of man could not find them out; yet once they are revealed and proposed to us, do they not appear very consistent with our best reasonings about God or man, and consistent also with all other parts of divine revelation? ${ }^{165}$

However as we will see in our next section Watts also speaks of Christian doctrine as above reason, which creates a tension for him.

\subsection{Christian doctrine above reason}

We've seen that Watts has a similar position to Locke in regarding some Christian truths as 'above reason'. Locke meant 'above reason' in that reason would never have discovered these truths. ${ }^{166}$ Watts agrees but goes further to say that some doctrines are above reason in our not being able to comprehend them. He distinguishes between these

\footnotetext{
${ }^{163}$ Watts, Works, 'Harmony of Religion', Volume 2, 542.

${ }^{164}$ Ibid., 'Sermons', Volume 1, 166.

${ }^{165}$ Ibid., 'Redeemer and Sanctifier', Volume 3, 760.

${ }^{166}$ Locke, Essay, IX.xvii.23: 687.
} 
two categories in his sermons. In discussing mysteries that might be held as a source of shame to the Christian he says they are of two sorts:

First, Such as we should never have known but by divine revelation; but being once revealed, they may be fairly explained and understood...

Other sorts of mysteries are those, which when revealed unto us, we know merely the existence or reality and certainty of them, but cannot comprehend the manner and mode of how they are. ${ }^{167}$

Examples in the second category are the incarnation and the Trinity. While saying that these are above comprehension Watts still insists that reason leads us to believe in such a category of belief: 'Reason itself teaches me to believe some things that are above my understanding. 168

This is also where Watts introduces a caveat on his usual approach to words and ideas. We saw above that Watts followed Locke in avoiding use of words without clear and distinct ideas. But what is usually a foundation stone for Watts does not apply when speaking of areas of mystery such as the person of God, the divine and human natures of Christ, and the work of his Spirit. Watts says we do not have clear ideas of these areas, and yet they should not be discarded as 'words without ideas' because 'there is sufficient evidence for the reality and certainty of the existence of their objects. ${ }^{169}$ So there is a realm of Christian doctrine that is not only above reason but which is not properly comprehensible to it. ${ }^{170}$

\footnotetext{
${ }^{167}$ Watts, Works, 'Sermons', Volume 1, 168.

${ }^{168}$ Watts, "Wattiana," 'A treatise on the dispositions to be cherished and the means to be employed in the search after religious truth', 268.

${ }^{169}$ Watts, Works, 'Logic', Volume 5, 44.

${ }^{170}$ For earlier discussion of doctrine above revelation and application to the Trinity see Sarah Mortimer, Reason and Religion in the English Revolution: the Challenge of Socinianism (Cambridge: Cambridge University Press, 2010), Chapter 6. For a similar example in Robert Boyle see Wojcik, Robert Boyle, especially chapter 4. The original work is Robert Boyle, A Discourse of Things Above Reason (London: Jonathan Robinson, 1681).
} 
Watts then has an earnest desire to defend revelation by showing how it fits with reason while also recognising that in some areas revelation rises above reason. This results in a tension in his works, seen most clearly in his writing on the Trinity and the person of Christ. Speaking of the incarnation Watts describes his approach saying, 'And in this place I would not on the one hand go beyond scripture, nor on the other hand would I talk without ideas. ${ }^{171}$

We see Watts being pulled in these two directions as early as 1696 when he writes to a friend about his 'experiment' with free thinking. He says:

I have made experiment of this in my own meditations; when I have given my thoughts a loose, and let them rove without confinement, sometimes I seem to have carried reason with me even to the camp of Socinius; but then St. John gives my soul a twitch, and St. Paul bears me back again (if I mistake not his meaning) almost to the tents of John Calvin. ${ }^{172}$

This section also comments on Watts' stated method of keeping Scripture as a guide and using reason as 'a necessary instrument to compare the several parts of revelation together, to discover their mutual explication, as well as to judge whether they run counter to any dictates of natural light.' The comment above is written in the context of what happens when in using that reason an inquisitive mind overleaps the bounds of faith.' So Watts knew where the limits were, but found that his own method wrestled with those limits. In his later published writings on the Trinity we see these two repeated elements: that we must limit ourselves to what Scripture says, and an attempt to present a doctrine that is seen to be reasonable. This resulted in wrestling with formulations of the Trinity for most of his life.

Watts felt compelled to write on the Trinity because of the charge of irrationalism. So he says in the preface to his third work on the topic:

It seems proper therefore, for some persons to endeavour to make it appear, that there is a possibility in the reason and nature of things, for true and

\footnotetext{
${ }^{171}$ Watts, Works, 'Useful and Important Questions', Volume 6, 709.

${ }^{172}$ Ibid., 'Reliquiae Juveniles', Volume 4, 532.
} 
eternal deity to be attributed to the Father, the Son and holy Spirit, without danger of those absurdities and inconsistencies which are pretended to arise thence. ${ }^{173}$

In later speaking of 'explications' of the Trinity Watts says they are of use because they 'vindicate this doctrine against the cavils of the unbeliever as well as against the scoffery and insults of the profane world. ${ }^{, 174}$ This leads Watts to give an explanation of the Trinity so as to 'remove all appearance of inconsistency' 175 , and to 'make this great doctrine appear consistent with reason., ${ }^{176}$

However Watts' attempts result in a struggle to give distinct personhood to the Son and Spirit. The result is a scheme hypothesising an eternal human soul of Christ which is joined to the divine nature, and to speak of the Spirit more as a divine power than a divine personality. ${ }^{177}$ So one biographer says Watts had a "proneness to torture the mystery of godliness into a congruity with new schemes and explications. ${ }^{178}$ While Watts never actually strays into either Arianism or modalism his desire to give rational explanation certainly means he departs from traditional Trinitarian belief. ${ }^{179}$

However Watts is also concerned to submit his reason to Scripture and hence he says concerning the Trinity:

It is a general and excellent rule, that where two propositions are evidently true, we are not to reject either of them, because we cannot at present find

\footnotetext{
${ }^{173}$ Ibid., 'Dissertations', Volume 6, 545-46.

${ }^{174}$ Ibid., 'Useful and Important Questions', Volume 6, 719.

${ }^{175}$ Ibid., 'Dissertations', Volume 6, 548.

${ }^{176}$ Watts, "Letters," 340.

${ }^{177}$ See the discussion by J. van den Berg, "The Idea of the Pre-Existence of the Soul of Christ: An Argument in the Controversy between Arian and Orthodox in the Eighteenth Century," in Tradition and Reinterpretation in Jewish and Early Christian Literature, ed. J. W. van Henten (Leiden: E. J. Brill, 1986).

${ }^{178}$ Milner, Watts, 397.

${ }^{179}$ Davis, Watts, 111.
} 
the modus or manner how they are reconciled. I would be ever mindful of the weakness and narrowness of our understandings... ${ }^{180}$

Similarly when considering the Arian scheme but seeing its deficiencies, he says: 'I render hearty thanks to God, who hath so guarded the freedom of my thoughts, as to keep them religiously submissive to plain revelation. ${ }^{181}$

This tension regarding the Trinity continued throughout Watts' life and his final work on the matter contains a plaintive plea for understanding:

How shall a poor weak creature be able to adjust and reconcile these clashing ideas, and to understand this mystery? Or must I believe and act blindfold, without understanding? ${ }^{182}$

This wrestling between reason and revelation is also seen in Watts' soteriology. While Watts does not list this as one of the 'mysteries' that we cannot comprehend, he attempts to explain divine sovereignty and human freedom in a way comprehensible to reason. In earlier life he speaks of holding to a more rigorous Calvinism ${ }^{183}$ but when he writes Ruin and Recovery he argues for a middle way which he believes can reconcile Calvinistic and Arminian positions. ${ }^{184}$ It is a position where Christ died specifically for the elect but his death also provides the possibility of a conditional salvation for the non-elect. ${ }^{185}$

This position has resulted in Watts being referred to as a 'study in hesitant Calvinism,"186 and as an example of his inconsistency and tendency to compromise. ${ }^{187}$ In support of

\footnotetext{
${ }^{180}$ Watts, Works, 'Dissertations', Volume 6, 544.

${ }^{181}$ Ibid., 'Christian Doctrine of the Trinity', Volume 6, 416.

182 Ibid., 'Remnants of Time', Volume 4, 640-41.

${ }^{183}$ He says he agrees with John Owen in the 'chief doctrines'. Milner, Watts, 182.

${ }^{184}$ Watts, Works, 'Ruin and Recovery', Volume 6, 297.

${ }^{185}$ In this regard Watts fits with later moderate Puritans such as Baxter and Howe. See discussion by Field, Rigide Calvinisme, Chapter 1. Also see Lee Gatiss, For Us and Our Salvation: 'Limited Atonement' in the Bible, Doctrine, History and Ministry (London: Latimer Trust, 2012), Chapter 3. ${ }^{186}$ Stromberg, Religious Liberalism, 116.

${ }^{187}$ Davis, Watts, 222.
} 
this he says himself in a letter that he was motivated by a concern to introduce 'softenings and allays to the harsher and more obnoxious censures which attend severall of those doctrines. ${ }^{188}$

However just as significant as these motivations is his desire to reconcile reason and revelation. We have mentioned that the aim of this whole work was to vindicate the Scriptural doctrines 'upon the plain principles of reason.' He also says that he hopes to 'render these sacred truths more intelligible and more credible', and to show 'how far they are supported by reason itself. ${ }^{189}$ With regard to the extent of the atonement, he says:

I am only endeavouring to try, whether I cannot represent a plain defensible scheme, wherein this doctrine will sit easy on the minds of men, without straining or torturing any text of scripture. ${ }^{190}$

Hence while a number of motivational factors may be at play, this is clearly an example of Watts' attempt to reconcile reason and revelation.

\subsection{Summary}

Watts desires to show how reasonable the Christian faith is, and yet recognises he must accept that some doctrines remain mysteries. Compared to Locke then there is a greater emphasis that where God has revealed himself 'reason must submit to faith', even when reason cannot reconcile a revealed proposition with its own principles or with another revealed proposition. Revealed truth cannot be inconsistent with reason and so when it appears to be so it is only by appearance, says Watts. But he recognises that we may remain in darkness until the world to come. ${ }^{191}$ Despite these caveats Christians should be assured how consonant with reason their faith is, and be convinced of their reasons for believing it.

\footnotetext{
${ }^{188}$ Watts, "Letters," 389.

${ }^{189}$ Watts, Works, 'Ruin and Recovery', Volume 6, 180.

${ }^{190}$ Ibid., 'Ruin and Recovery', Volume 6, 278.

${ }^{191}$ Ibid., 'Logic', Volume 5, 121.
} 
We see a summary of this position in one of Watts' letters. Writing to a lady about inward passions he says:

Faith itself is a very rational Grace; it knows what and why it believes tho (as I said before) there are two or three mysterys in our Religion proposed to our faith which reason cant comprehend nor easily reconcile, yet faith can give a rational account why it believes them. ${ }^{192}$

He goes on to say that a Christian should never say that they believe simply because they believe: 'God will not suffer the faith of his Children to become a laughing stock of men and sport of the Carnal World.'

This means Watts expends great effort in justifying orthodox faith according to the principles of reason, including those areas which we regards as mysteries. So speaking of his unusual scheme on Christ's human soul he says it will make it 'more intelligible and delightful' to Christians, and 'much more defensible' against those who doubt. ${ }^{193}$ It is as if, even though he has declared such an area off-limits to reason, he cannot but help himself show how they are reasonable.

This position is also seen in Watts' hymns. A hymn entitled 'Divine glories above our reason' includes the following stanza:

Our reason stretches all its wings, And climbs above the skies; But still how far beneath thy feet Our grov'lling reason lies! ${ }^{194}$

This hymn goes on to speak of how the 'weak pinions of our mind' can not stretch far enough to understand God. Similarly in a hymn entitled a 'Song of praise to the blessed Trinity' the last verse reads:

\footnotetext{
${ }^{192}$ Isaac Watts, "Letter to a lady about inward impulses," (London: British Library).

${ }^{193}$ Watts, Works, 'Glory of Christ Jesus', Volume 6, 803.

${ }^{194}$ Ibid., 'Hymns', Volume 4, 229.
} 

Almighty God to thee
Be endless honours done,
The undivided Three,
And the mysterious One:
Where reason fails
With all her pow'rs,
Their faith prevails
And love adores. ${ }^{195}$

Here faith gains access to knowledge which reason cannot and results in the adoration of love not just understanding. Hence while remaining troubling to him, for Watts Christian truths about God that lie above reason also become reasons for praise.

\section{Reason and Christian experience}

\subsection{The reasonableness of Christian experience}

While enthusiasm was variously defined, for everyone it was the enemy, and the opposite of reason. ${ }^{196}$ The central element to enthusiasm was laying claim to private revelations from $\operatorname{God}^{197}$, although it was also linked with what were considered extremes in Christian experience. ${ }^{198}$ Locke's position on enthusiasm was characteristic of the age: God has given us the natural faculty of reason which we should then cultivate and use rather than thinking God would reveal himself directly to individuals. ${ }^{199}$ This means that Locke questions those who are so sure they 'see' something as unquestionably true without the appropriate external evidence. They are those whose 'confidence is mere presumption', and he highlights the circularity of their arguments: '...it is a revelation, because they firmly believe it; and they believe it, because it is a revelation. ${ }^{200}$ So Malherbe says Locke opposed enthusiasm as it was 'the exact opposite of reason since in the name of God (as a matter of fact, because of too

\footnotetext{
195 Ibid., 'Hymns', Volume 4, 269.

${ }^{196}$ Rivers, "Religion and Literature," 449.

${ }^{197}$ See Locke's description in Locke, Essay, IV.xix.6: 699.

${ }^{198}$ See for example descriptions in Jane Shaw, "Mary Toft, Religion and National Memory in Eighteenth

Century England," Journal for Eighteenth-Century Studies 32, no. 3 (2009).

${ }^{199}$ Jolley, "Faith and Reason," 448.

${ }^{200}$ Locke, Essay, IV.xix.10: 702.
} 
vivid imagination or the influence of passions) it intends to free any evidence from a critical appraisal. $^{201}$

Watts in essence agrees with this analysis. He speaks equally disparagingly of, 'the land of blind enthusiasm, that region of clouds and darkness, that pretends to divine light. ${ }^{202}$ He consistently defends traditional Christian belief against the charge of enthusiasm. For example in speaking of the Christian's confidence in the face of death he says, 'Nor is this hope a vain presuming confidence, or a bold fit of enthusiasm. ${ }^{203}$

While Watts criticised enthusiasm, he also wished to promote vital, experiential Christianity. We have noted in the introduction how Watts believed his age had progressed in its use of reason but had lapsed in its piety. So in his first volume of published sermons he chooses to focus on the experiential nature of true religion. He says in the preface that he did so because he believes this is not properly emphasised in his day and he wishes to 'rescue those arguments from the charge of enthusiasm and to put them in such a light as might shew their perfect consistence with common sense and reason. ${ }^{204}$ Hence Watts wants to maintain the inward reality of faith and Christian experience, but also to locate these topics in the realm of reasonable Christianity.

In his aim to revive experimental religion Watts knows that he is flirting with the dangers of enthusiasm: in his Evangelical Discourses he acknowledges that his discussion of experience means he could be branded an enthusiast. However he responds:

There is nothing in all this account of things but what is perfectly agreeable to the word of God, and to the rational actings of created minds, under the happy influences of the uncreated Spirit. ${ }^{205}$

\footnotetext{
${ }^{201}$ Malherbe, "Reason," 322.

${ }^{202}$ Watts, Works, 'Sermons', Volume 1, 5.

${ }^{203}$ Ibid., 'Sermons', Volume 1, 442.

${ }^{204}$ Ibid., 'Sermons', Volume 1, xxii.

${ }^{205}$ Ibid., 'Evangelical Discourses', Volume 2, 91.
} 
In this work he defends his position by giving examples of those who have spoken of their experience of God and argues that they would never be considered enthusiasts themselves. His main example is John Howe of whom he says:

...the example of a person whose solid sense, whose deep sagacity, whose sedate judgement, and the superior excellence of his reasoning powers, leave no room to charge him with vain and dilusive raptures of a heated imagination. ${ }^{206}$

Here is defence of experiential religion against exactly the kind of accusations that Locke made against enthusiasts. ${ }^{207} \mathrm{We}$ will return to examine this area in more detail in the next chapter.

\subsection{Christian experience above reason}

While Christian experience is defended by Watts as being perfectly reasonable, he also argues that elements of experience cannot be comprehended by reason. This bears a similarity to his position on reason and doctrine examined above.

First, Watts distinguishes between the ordinary and extraordinary witness of the Spirit. For Watts the ordinary witness of the Spirit involves the aid of the Spirit in identifying marks of grace within us in a syllogistic fashion which we will examine below. However the extraordinary witness is where God operates by a 'more immediate and more sensible manner. ${ }^{208}$ By 'immediate' Watts means sudden, not necessarily without means such as prayer or meditation.

This experience is where the heart is given an impression of divine love such that the person has a 'powerful and pleasant sense' that they are God's. It involves an experience where they are 'raised to holy raptures, to heavenly joy and assurance.'209 While wanting to make room for this kind of experience Watts gives guidance to

\footnotetext{
${ }^{206}$ Ibid., 'Evangelical Discourses', Volume 2, 97.

${ }^{207}$ Locke, Essay, IX.xix.5-7: 698-99.

${ }^{208}$ Watts, Works, 'Evangelical Discourses', Volume 2, 94.

${ }^{209}$ Ibid., 'Evangelical Discourses', Volume 2, 94.
} 
distinguish such experience from the work of Satan or a deluded imagination, and also gives cautions in not making too much of such experiences. While these experiences must not despised, he argues, it is the ordinary witness of the Spirit that should be sought: 'Value mortification to sin more than raptures; for mortification is a certain sign that the Spirit of God dwells in us, and that we are heirs of life. ${ }^{210}$

Second, we see a repeat of Watts' willingness to relax his usual concern about words and ideas. We saw above his exception on this rule when dealings with certain doctrines. This is seen again in Watts' expectations of Christian experience which he sees as going beyond the description of words. ${ }^{211}$ Hence we see the following lines in a hymn based on Ephesians 3:16ff. ${ }^{212}$

Come, dear Lord, descend and dwell

By faith and love in ev'ry breast;

Then shall we know, and taste, and feel

The joys that cannot be express'd. ${ }^{213}$

This is a prayer by the believer for an experience of God that surpasses description in words. The next stanza continues this thought:

Come, fill our hearts with inward strength, Make our enlarged souls possess,

And learn the height, and breath, and length

Of thine unmeasurable grace.

This growth in 'sensational' knowledge of God's 'unmeasurable' grace contrasts sharply with Locke's paraphrase on these verses which simply spoke of understanding

\footnotetext{
${ }^{210}$ Ibid., 'Evangelical Discourses', Volume 2, 103.

${ }^{211}$ For an argument connecting this idea to post-modern worship see Daniel E. Ritchie, The Fullness of Knowing: Modernity and Postmodernity from Defoe to Gadamer (Waco: Baylor University Press, 2010), Chapter 2.

212 This text itself speaks of 'love which surpasses knowledge'.

${ }^{213}$ Watts, Works, 'Hymns', Volume 4, 190.
} 
'the exceeding Love of God. ${ }^{214}$ This comparison leads us on to the epistemological value of Christian experience.

\subsection{The epistemological value of experience}

Watts' first three published sermons examine the inward witness of Christianity from 1 John 5:10. We should recall the background of Locke's framework in how reason is used in evaluating whether revelation from God has taken place and, if so, trusting it as such. This framework is to the fore in Watts' argument.

Watts sets up his sermons by speaking of the need to establish whether Christianity is the true religion rather than presuming that it is. He speaks of 'outward' witnesses within history which concern the person and work of Jesus and the miracles of the apostles, and goes on to say that the text under consideration is about a corresponding 'inward' witness. ${ }^{215}$

Watts distances the meaning of this inward witness from any sense of enthusiasm: 'The apostle does not mean here a strong impulse, an irrational and ungrounded assurance. ${ }^{, 216}$ Rather he says this witness must approve itself to our reason. This distancing from enthusiasm and stressing the rational but experiential nature of religion is repeated throughout in these sermons.

The witness he thinks is spoken of is that of the experience of eternal life through Jesus which comprises both 'happiness' and 'holiness'. These each involve subjective elements such as awareness of forgiveness, hatred of sin, renewed harmony in our faculties, and delight in worship of God. For Watts this is a witness that dwells more in the heart than in the mind. That is not to derogate it though; on the contrary, according to Watts, because of this it has 'some prerogatives above all the external arguments for the truth of Christianity' and yet is still perfectly rational. ${ }^{217}$

\footnotetext{
${ }^{214}$ Locke, Paraphrase Volume 2, 644.

${ }^{215}$ Watts, Works, 'Sermons', Volume 1, 1-3.

${ }^{216}$ Ibid., 'Sermons', Volume 1, 5.

${ }^{217}$ Ibid., 'Sermons', Volume 1, 20.
} 
Hence Watts' argument is thoroughly experiential: the witness of the truth of Christianity is the awareness of change within me in the holiness and happiness that God has brought. Yet this approach is also thoroughly rational: 'My strictest and severest reason approves the change, and owns it to be divine. ${ }^{, 218}$

So when Watts preaches on 'The rational defence of the gospel' he concludes by saying that the gospel comes with 'such solid grounds and foundations as justifies its highest promises and proposals to the reason of men. ${ }^{219}$ However he goes on to say that the final assurance for the Christian is their experience of God in the transforming power of the gospel:

Learn hence the true method of obtaining Christian courage ... It is by getting it wrought in your hearts and lives by Christian experience, and not by learning a mere form of words in a road of education and catechism. You must feel it as the power of God to your salvation, or you will never suffer much for it. ${ }^{220}$

Indeed Watts says that while learning the defence of the faith through arguments is of great use, it can be overturned by the temptations of Satan and Christians may fall unless they have this experiential knowledge of God.

This approach is neatly summarised in the hymns Watts wrote to accompany these sermons. In one we see the existential nature of assurance:

Jesus thy witness speaks within;

The mercy which thy words reveal, Refines the heart from sense and sin And stamps its own celestial seal.

\footnotetext{
${ }^{218}$ Ibid., 'Sermons', Volume 1, 12.

${ }^{219}$ Ibid., 'Sermons', Volume 1, 191.

${ }^{220}$ Ibid., 'Sermons', Volume 1, 192.
} 
In the last verse of this hymn we can see a clear reference to Locke's requirement that a miracle confirm divine revelation. Watts states that the inward change God has brought is the miracle needed:

Learning and wit may cease their strife,

When miracles with glory shine;

The voice that calls the dead to life

Must be almighty and divine. ${ }^{221}$

Hence the existential awareness of new life provides appropriate proof of divine activity.

Here we see Watts utilising the approach of Locke but not in a way Locke envisioned. Watts is arguing that the experiential awareness of change acts as evidence that reason can examine and deduce that it must be from God. By contrast, as Wolterstorff says, 'Locke never explores the possibility that religious experience, of one sort or another, can provide evidence of theistic belief. ${ }^{222}$

We see a very similar position in Watts' Evangelical Discourses. Watts argues that we know the marks of conversion from the word and we can assess them by our reason:

The believer hath a witness in his own soul, to the power and grace of Christ when he feels holiness wrought in his heart by the gospel, and divine peace in his conscience, with the fore-tastes of heaven. ${ }^{223}$

This was an approach made previously by Puritans and elements in Watts echo the traditional Puritan position on assurance: the syllogistic argument, the requirement for diligent examination, the necessity of the Spirit's aid, and exhortations for repeated

\footnotetext{
${ }^{221}$ Ibid., 'Sermons', Volume 1, 34.

${ }^{222}$ Nicholas Wolterstorff, "Locke's Philosophy of Religion," in The Cambridge Companion to Locke, ed. Vere Chappell (Cambridge: Cambridge University Press, 1994), 195.

${ }^{223}$ Watts, Works, 'Evangelical Discourses', Volume 2, 74-75.
} 
examining throughout life. ${ }^{224}$ However the overall explanation is couched in terms of Locke's framework. $^{225}$

\section{Reason and the Spirit of God}

We finish our overview of Watts' view of reason by noting the importance for him of the work of the Spirit. For Watts the blinding nature of sin was such that God must work by his Spirit for people to come to knowledge of the truth. He writes to Benjamin Colman: 'tis God only who can make the consciences of unbelievers hear the voice of reason or revelation. ${ }^{, 26}$ Specifically with regard to revelation, he says: 'We are dark, ignorant and averse to God and all that is holy. We cannot learn divine things, savingly, without the teachings of the holy Spirit. ${ }^{, 227}$

In a sermon discussing faith without sight he distinguishes the kind of faith he is talking about. He says this is not a 'mere rational faith'; rather it is worked by 'divine illumination and sovereign and efficacious grace. ${ }^{228}$ Hence in speaking of how one comes to knowledge of the truth as well as diligent study of the Scriptures he speaks of dependence on enlightening grace. ${ }^{229}$

We see this view expressed in a letter to his brother:

\footnotetext{
${ }^{224}$ See for example Richard Sibbes, A Fountain Sealed: or, The duty of the Sealed to the Spirit, and the Worke of the Spirit in Sealing (London: Thomas Harper, 1637), Section 2, Chapter 3. For similar elements in Baxter and Bunyan see Rivers, Reason, Grace and Sentiment, Vol 1, 150-51.

${ }^{225}$ In this regard Watts may provide an early example of Bebbington's thesis regarding the use of the Lockean framework in the 'creation' of evangelicalism. See D. W. Bebbington, Evangelicalism in Modern Britain: A History from the 1730's to the 1980's (London: Unwin Hyman, 1989), 42-54. For a contrary opinion arguing that evangelicalism continues earlier Puritan themes see J. Coffey, "Puritanism, Evangelicalism and the Early Protestant Tradition," in The Emergence of Evangelicalism: Exploring Historical Continuities, ed. Michael A. G. Haykin and Kenneth J. Stewart (Nottingham: Apollos, 2008). ${ }^{226}$ Watts, "Letters," 335.

${ }^{227}$ Watts, Works, 'Caveat against Infidelity', Volume 2, 483.

${ }^{228}$ Watts, "Wattiana," 'Blessedness of faith without sight', 209.

${ }^{229}$ Ibid., 'A treatise on the dispositions to be cherished and the means to be employed in the search after religious truth'.
} 
Tis a heap of probabilitys that we judge by in most affairs of life and I would chuse it as soon as some demonstrations. Tho in the Scrip[tures] we are to hope for the Enlightening Spirit lest we sin against Christ as the great prophet of his Church. ${ }^{230}$

Here Watts reflects Locke who thought that if actual knowledge was not possible we had to work on probabilities and corresponding degrees of ascent ${ }^{231}$. For Watts though the work of the Spirit places reading the Scriptures in a different sphere.

The Spirit is most clearly operative for Watts in conversion: he brings conviction of sin and reveals the mercy of God in Christ. Watts speaks of the need for the Spirit in this conviction compared to the role of reason and conscience alone:

...mankind cannot be so brutish and stupid as to have lost all sense of religion, or all inward reproaches of conscience, reason it self examining the heart and life by the rules of the law of God written on the conscience must needs convince and condemn, but it cannot affect, it cant move, it cant make the soul to mourn unless the spirit of God convince. ${ }^{232}$

In conversion Watts speaks in terms of the Spirit bringing spiritual sight to the soul:

It is the Spirit, who effectively reveals Christ Jesus to the soul, as the great reconciler. He discovers who Christ is, and what he has done for us, and sets him before us in all the glories of his mediation. He makes the soul see the all-sufficiency of his sacrifice to atone for sin, the efficacy of his intercession to prevail with God, and his power to save to the uttermost. ${ }^{233}$

And this work is different to simply having access to revelation in Scripture:

\footnotetext{
${ }^{230}$ Isaac Watts, "Letter to younger brother," (London: British Library, 1699).

${ }^{231}$ See Locke's essay on 'Probabilities' (IV.xv) and 'Degrees of Ascent' (IV.xvi).

232 Isaac Watts, "Sermon Manuscripts," (London: British Library, 1702).

${ }^{233}$ Watts, Works, 'Sermons', Volume 1, 503.
} 
All the teachings of men, and all the words in the bible, cannot make a sinful creature see such glory in Christ, such grace, and so desirable salvation, as is done by the enlightening work of the holy Spirit. ${ }^{234}$

Sell says that while Locke did not deny the need for the illumination of the Spirit but he was cautious regarding it. ${ }^{235}$ By comparison Watts insisted on it. We should also note however that this emphasis on the work of the Spirit did not mean Watts was fideistic in any way. Rather he used what he regarded as reasonable arguments to strengthen the faith of believers and to challenge unbelief. In this regard he sometimes expresses an ambivalence towards the noetic effects of sin. He can state that the atheist is so blinded that he will never listen to rational argument; but he can also say that if anyone would be 'impartial' they would grasp the truth. ${ }^{236}$

There is an interesting comment on this in a letter to Watts' friend Samuel Say. Watts says that arguments for the truth of Christianity in his day are utterly convincing: "never since the apostles days were equal arguments for Christianity produced.' And yet he recognises, 'few are convinced.' His conclusion is: 'I am ready to say that Faith, though a Rationall thing in itself, is yet the gift of God. Not by might of arm, nor by power of argument, but by my spirit, saith the Lord. ${ }^{237}$

Secondly the Spirit is significant in the knowledge of assurance. We noted above Watts' encouragement that Christians should establish themselves in good reasons for their faith. Yet he did not see this 'intellectual' exercise as opposed to dependence on God for the work of the Spirit, rather the two should go together:

When you are satisfied of the truth of Christianity, upon just and reasonable grounds, make it your constant prayer to God the Father of spirits, to establish you in this faith... It is the Spirit of God that enlightens us in the

\footnotetext{
${ }^{234}$ Ibid., 'Sermons', Volume 1, 503.

${ }^{235}$ Sell, John Locke, 97.

${ }^{236}$ Watts, Works, 'Caveat against Infidelity', Volume 2, 470; 'Ruin and Recovery', Volume 6, 180.

${ }^{237}$ Isaac Watts, "Letter to Samuel Say, 7 Spetember 1732," (London: Dr Williams's Library, 1732).
} 
knowledge of the gospel, and he seals our souls unto the day of redemption. ${ }^{238}$

We have also seen Watts' view of assurance through the epistemological value of Christian experience, and we should lastly note that, for Watts, this too is only possible by the work of the Spirit. While we are responsible to assess the signs of grace by our own reason and judgment, the Spirit aids us in this:

The Spirit of God; by his power, and by his providence, awakens these holy dispositions into lively exercise; He assists our enquiring and judging faculties, helps us to compare our own souls with his word, and thus confirms our spirits in the belief of this proposition, that we are the children of God. ${ }^{239}$

\section{Watts' position within his own day}

We have examined Watts' position on the role of reason and done so specifically with regard to the work of John Locke. We will now outline how Watts fitted into the range of views on reason within his own day. We will place them in three categories while accepting the boundaries between them are not watertight and there is the potential for variation within them.

\subsection{Reason over against revelation}

The most elevated view of reason was held by those usually designated deists or the wider category of freethinkers. ${ }^{240}$ The distinguishing feature of this group was their view of the authority of reason independent of revelation. ${ }^{241}$ This meant that reason was

\footnotetext{
${ }^{238}$ Watts, Works, 'Caveat against Infidelity', Volume 2, 530.

${ }^{239}$ Ibid., 'Evangelical Discourses', Volume 2, 91.

${ }^{240}$ Isabel Rivers, Reason, Grace and Sentiment: A Study of the Language of Religion and Ethics in England, 1660-1780, Volume 2, Shaftesbury to Hume (Cambridge: Cambridge University Press, 2000$), 7$.

${ }^{241}$ Gerald Robertson Cragg, Reason and Authority in the Eighteenth Century (Cambridge: Cambridge University Press, 1964), 62. For different groups of deists see Samuel Clarke, A Discourse Concerning the Being and Attributes of God, the Obligations of Natural Religion, and the Truth and Certainty of the Christian Revelation. (London: W. Botham, 1728), 155-60. Also see the categories of 'mortal' and
} 
seen to be able to give a clear knowledge of God and morality such that revelation was rendered unnecessary. Some took the logical next step of saying that reason should assess revelation and be able to correct or dismiss it.

The most famous example is Matthew Tindal's Christianity as Old as the Creation. ${ }^{242}$ Tindal argued that revelation was only a republication of the religion of nature. His propositions included: 'That the Religion of Nature is absolutely perfect; and that external Revelation can neither add to nor take away from its Perfection. ${ }^{243}$ Another well known example is Anthony Collins, whose Discourse of Free Thinking included examples of early biblical criticism. ${ }^{244}$

The deists were one of Watts' most consistent targets in his writings on reason. His work The Strength and Weakness of Human Reason was specifically written to convince an enquiring deist as to the weakness of unaided reason. This work is written in the style of a dialogue between persons of different sentiment. Watts states that this was to make it easier to read; it may also have been done specifically to replicate the dialogue of Tindal's famous work. ${ }^{245}$ Similarly Watts' Caveat against Infidelity is written against the deist position and Watts' chief aim in writing it is to 'attempt a recovery of some of these doubting Christians, or to stop them in their course towards apostasy. ${ }^{246}$

In addition The Redeemer and the Sanctifier was written addressing those who reduce religion to 'the mere dictates of the light of nature.' The focus in this work though was

'immortal' deists by Thomas Halyburton, Natural Religion Insufficient; and Reveal'd Necessary to Man's Happiness in his Present State (Edinburgh: Andrew Anderson, 1714), 1-5.

${ }^{242}$ Matthew Tindal, Christianity as Old as the Creation: or, the Gospel, a Republication of the Religion of Nature (London1730).

243 Ibid., 49.

${ }^{244}$ Anthony Collins, A Discourse of Free-Thinking (London, 1713), 42-46. For early examples of biblical criticism in sermons see Francoise Deconinck-Brossard, "Eighteenth-Century Sermons and the Age," in Crown and Mitre: Religion and Society in Northern Europe Since the Reformation (Woodbridge: Boydell Press, 1993), 120-21.

${ }^{245}$ There is also the background of other works in this style such as Boyle, Things above Reason. Also see discussion of Ciceronian dialogue by Rivers, Reason, Grace and Sentiment, Vol 2, 30-31.

${ }^{246}$ Watts, Works, 'Caveat against Infidelity', Volume 2, 471. 
more on the deist's denial of the need for atonement through Christ and renewal by the Holy Spirit. ${ }^{247}$ Hence these are some of Watts' most apologetic and evangelistic works to convince deists of the error of their ways and to reassure those who might be tempted by their arguments.

\subsection{Revelation alongside reason}

Revelation assisting or working alongside reason in some way is the majority position in the early eighteenth century. However while this category sees the need for revelation there are many different views within it as to exactly how it fits with reason. The most common position is that reason in its perfect state would have led to right knowledge of God, but the fall now means that our nature is corrupted and reason is obscured. This sets limits on reason and makes revelation necessary. Considerable variation remains however in where the limits of reason fall and how revelation and reason now relate to each other.

The group usually designated Latitudinarians fit into this category. They are more recognisable by a cluster of attitudes than any specific doctrinal position. Cragg says their favourite theme is the reasonableness and credibility of natural religion; Christianity builds on reason but rests on its foundations. ${ }^{248}$ This group may be seen as the most Lockean in approach.

For some of this group revelation was not given primarily to provide information, but to give additional incentives to godliness. Revelation supplements, not the informational, but the motivational weaknesses of reason. So John Jackson ${ }^{249}$ says that:

Christianity was not then necessary in Respect of the absolute Insufficiency of Human Reason ... but it was necessary only to display the great Mercy and Goodness of God.... 250

\footnotetext{
${ }^{247}$ Watts, Works, 'Redeemer and Sanctifier', Volume 3, 731-32.

${ }^{248}$ Cragg, Reason, 28.

${ }^{249}$ Anglican minister (1686-1763).

${ }^{250}$ John Jackson, A Plea for Humane Reason, Shewing the Sufficiency of it in Matters of Religion (London: J. Roberts, 1730), 7.
} 
This display God's mercy was primarily to give greater motivation to our obedience. Hence the light of revelation is:

...enforced with stronger Motives to Obedience than Reason alone could propose, thereby to render the Law of Natural Piety and Morality more effectual, by the Declaration of free Grace, and Pardon unto Sinners... ${ }^{251}$

Watts too refers to the motivational benefits of revelation, but clearly disagrees with this group as to the necessity of revelation.

The majority position however was that reason was primarily required because of our needing new information, while still holding reason as foundational to revelation. ${ }^{252}$ Many leading divines held a version of this rational but orthodox belief. ${ }^{253}$ So Edmund Gibson $^{254}$, whom Jackson above was writing against, says:

Be not persuaded to part with Revelation under Pretence of relying on Natural Reason as your only guide. For Reason without the Assistance given it by Revelation, has in fact appear'd to be a very insufficient Guide. ${ }^{255}$

He goes on to gives arguments similar to those of Watts in Strength and Weakness of Human Reason. Gibson and Watts seemed to agree on a number of areas as shown by their friendly correspondence and positive comments on each other's works. ${ }^{256}$

Similarly, Thomas Sherlock ${ }^{257}$, who succeeded Gibson as Bishop of London, emphasised that revealed religion confirmed what reason might have led us to believe

\footnotetext{
${ }^{251}$ Ibid., 10.

${ }^{252}$ Sell, John Locke, 80.

${ }^{253}$ Cragg, Reason, 50-52.

${ }^{254}$ Edmund Gibson (1669-1748), Bishop of Lincoln and London.

${ }^{255}$ Bishop Gibson, The Bishop of London's Pastoral Letter to the People of his Diocese (Dublin: J. Watts, 1728), 9.

${ }^{256}$ See for example the positive comments of Gibson on Strength and Weakness, Milner, Watts, 490-91.

${ }^{257}$ Thomas Sherlock (1677-1761), Bishop of Bangor, Salisbury and London.
} 
uncertainly, and brought our faith and reason together. For example in speaking of our hope of immortality he says that the resurrection of Jesus 'has restored Religion, which had hardly one sound foot to stand on, and made our Faith and our Reason consistent, which were before at too great a distance. ${ }^{258}$

Sherlock also argues for a foundational position of natural religion that revelation cannot overturn. He says:

Upon this Account 'tis impossible that any true Revelation should contradict or evacuate any clear Dictate of Natural Religion, which stands at least upon as good a Bottom as any Revelation can do. And therefore the Principles of Natural Religion must be supposed for the Foundation of Revealed. ${ }^{259}$

Watts' position as we've seen would lead him close to this, but he would be more concerned to hold Scripture as the higher authority and submit to Scripture even when there was an apparent contradiction between reason and revelation.

Another important figure is Bishop Butler ${ }^{260}$ and his well known work The Analogy of Religion. ${ }^{261}$ Butler worked on the basis of the similarity between nature and Scripture as God was the author of both, alongside an understanding of probability rather than certainty in our knowledge. Watts mentions a similar analogical argument when discussing the mysteries of the faith in his sermons: 'In the world of nature there are mysteries of this kind, which are unaccountable, and as hard to be unfolded as the mysteries of grace. 262

\footnotetext{
${ }^{258}$ Thomas Sherlock, Several Discourses Preached at the Temple Church. (London: J. Whiston and B. White, W. Owen, and E. Baker, 1754), 209.

${ }^{259}$ Ibid., 276-77.

${ }^{260}$ Joseph Butler (1692-1752), Bishop of Bristol and Durham.

${ }^{261}$ Joseph Butler, The Analogy of Religion, Natural and Revealed, to the Constitution and Course of Nature. (London: James, John and Paul Knapton, 1736).

${ }^{262}$ Watts, Works, 'Sermons', Volume 1, 169.
} 
Butler assumes the ability of reason to discover truths about God but also draws limits on this. He seems to have been open to the possibility of revelation not having been actually necessary, but thought that in practice it was. For example:

It is impossible to say, who would have been able to reasoned out That whole System, which we call natural Religion, in its genuine Simplicity, clear of Superstition; but there is certainly no Ground to affirm that the Generality could. If they could, there is no sort of Probability, that they would. Admitting there were, they would highly want a standing Admonition, to remind them of it, and inculcate it upon them. ${ }^{263}$

This is a not dissimilar position to Watts in Strength and Weakness, although it is more open to the potential of reason. Butler also emphasised the republication of natural religion through revelation while maintaining its additional content: 'For though natural Religion is the Foundation and principal Part of Christianity, it is not in any Sense the whole of it. ${ }^{264}$

Samuel Clarke ${ }^{265}$ is also an important figure in this discussion. He defended revelation against deists and yet veered towards a form of rationalism. ${ }^{266}$ This resulted in his holding a semi-Arian position on the Trinity. ${ }^{267}$ Watts was familiar with Clarke's writings and quotes him favourably in a number of areas, especially in support of the need for revelation (while distancing himself from Clarke's Christology). ${ }^{268}$

Clarke argued that much of Christian doctrine was demonstrable by reason but that the majority of mankind did not attain it because of ignorance and superstition, sinful passions, and above all vicious habits. ${ }^{269}$ This meant that revelation was necessary and revelation was seen to include truths that reason could not have found out. Watts is very

\footnotetext{
${ }^{263}$ Butler, Analogy of Religion, 142.

${ }^{264}$ Ibid., 144.

${ }^{265}$ Samuel Clarke (1675-1729), Anglican clergyman.

266 Sell, John Locke, 67.

${ }^{267}$ While commonly referred to as 'Arianism' Clarke actually held to the eternity of the Son, but not his equality with the Father. See Stromberg, Religious Liberalism, 44-45.

${ }^{268}$ For example Watts, Works, 'Strength and Weakness ', Volume 2, 217-58.

${ }^{269}$ Clarke, Natural Religion, 276-77.
} 
similar is his view of why reason does not lead us rightly. However Clarke takes his position to the logical conclusion of saying that the only answer to unbelief is for men to become impartial so they can make right judgements, and he calls them to do so. ${ }^{270}$ Watts would say that they cannot and will not do so unless God works to open their blind eyes.

Also for Clarke, once truth is revealed, we can understand how revelation and reason fit together:

Now indeed, when our whole Duty, with its true motives, is clearly revealed to us; its Precepts appear plainly agreeable to Reason ... Nay, after our Duty is thus made known to us, 'tis easy not only to see its agreement with Reason, but also to begin and deduce its Obligation from Reason. ${ }^{271}$

Clarke goes to speak of how Christianity is the only 'reasonable' religion. ${ }^{272}$ These sentiments have overlap with Watts, although Clarke gives greater potential to reason, and we note the space Watts wished to grant for revelation that is above reason.

Our last example is Thomas Halyburton. ${ }^{273}$ His work Natural Religion Insufficient, which was written against deism, is very similar to Watts. Reason is held as important, true revelation is regarded as reasonable, and yet natural religion is argued to be insufficient in both content and motivation. Halyburton also disagrees with Locke on his belief that reason is able to lead those who have not benefited from revelation to salvation. ${ }^{274}$ Watts later wrote a preface to Halyburton's memoirs and specifically praised his work against the deist position. ${ }^{275}$

\footnotetext{
${ }^{270}$ Ibid., 451.

${ }^{271}$ Ibid., 312. This is a point that Locke had previously made in his Reasonableness of Christianity.

272 Ibid., 334.

273 Thomas Halyburton (1674-1712). Professor of theology at St Andrews University.

${ }^{274}$ Halyburton, Natural Religion, 134. p134.

275 Thomas Halyburton, Memoirs of the Life of the Reverend, Learned and Pious Mr. Thomas Halyburton. With a large Recommendatory Epistle by I. Watts (London: R. Cruttenden, 1718).
} 


\subsection{Revelation over against reason}

The borderline between this group and the one above is blurred as even in this group reason was often viewed highly. The difference is seen in assigning reason and revelation to different spheres of knowledge such that no attempt is made to relate them which goes hand in hand with assigning a lower place to reason.

So for example William Law ${ }^{276}$ argued specifically against Tindal but included all those who looked to reason for support including the Latitudinarians. ${ }^{277}$ Sell says that for Law:

...reason offers no support to Christianity, nor is it capable of refuting it. It is utterly distinct from revelation, and can in no sense judge its deliverances. It has nothing to say where matters of faith or morals are concerned. ${ }^{278}$

Indeed for Law the claim made by Tindal for the authority of reason was an example of the very same pride that lay behind the fall of angels into devils. ${ }^{279}$

A different example is seen in the Calvinistic independent minister Thomas Bradbury. ${ }^{280}$ He was a direct contemporary of Watts in London and the two ministers were friends before falling out. ${ }^{281}$ Bradbury wrote fervently about the necessity of revealed religion. For example with regard to the atonement he says:

Are these the things that Man's Wisdom teaches? Does any Philosophy so much as receive it? 'Tis refused by the Lusts of People, nay by their most

\footnotetext{
${ }^{276}$ William Law (1686-1761), Anglican clergyman.

${ }^{277}$ William Law, The Case of Reason, or Natural Religion, Fairly and Fully Stated (London: W. Innys, 1731).

278 Sell, John Locke, 65.

${ }^{279}$ Law, Case of Reason, 7-8. See outline and discussion by B. W. Young, Religion and Enlightenment in Eighteenth-Century England: Theological Debate from Locke to Burke (Oxford: Clarendon Press, 1998), 126.

${ }^{280}$ Thomas Bradbury (1677-1759), Congregationalist minister.

${ }^{281}$ See Davis, Watts, 58-61.
} 
exalted Reason. The carnal mind is enmity against God; and the natural man in all his Imaginations must be cast down before him. ${ }^{282}$

He goes to say of Christ's sacrifice in our place: 'These are Absurdities to the Reason of Man: No Learning will bow to 'em, till the Spirit of God takes the Weapons of our Warfare into his own hand. 283

Hence there is no attempt to show the reasonableness of these foundational truths of the faith as Watts attempted in The Redeemer and the Sanctifier. Rather it is presumed that such truths will be irrational to people until God works in them to sanctify their reason.

Even for Bradbury though reason still plays a role in assessing evidence for revelation and then bowing to whatever it says (in a similar way to Watts above):

Never can human Reason do a thing more worthy of itself, than when it receives what infallible truth has told it. 'Tis enough for Reason to be satisfied, that the Revelation comes from God; and, after that, there ought to be an Acquiescence and Subjection of all Scruples that may arise in our mind against it. ${ }^{284}$

A final example is the Calvinistic Baptist John Gill. ${ }^{285}$ He argues that the light of nature is impaired but not wholly lost by the fall. The result is that it is not sufficient to guide us to salvation, but does still make us aware of God and so give enough light to condemn. ${ }^{286}$ Gill is also willing to say that when Christian doctrine overlaps with the thought of ancient philosophers it is because it is 'consonant to the light of nature, and far from being repugnant to the natural reason of mankind. ${ }^{287}$

\footnotetext{
282 Thomas Bradbury, The Necessity of Contending for Revealed Religion (London: H. Woodfall, 1720),

39.

283 Ibid., 40.

${ }^{284}$ Ibid., 84

${ }^{285}$ John Gill (1697-1771), Baptist minister.

${ }^{286}$ John Gill, Levi's Urim and Thummim found with Christ (London: Aaron Ward, 1725), 21-22.

${ }^{287}$ John Gill, The Cause of God and Truth (London: Aaron Ward, 1735-38), Volume 3, 196.
} 
However elsewhere he echoes the sharp dichotomy between natural and spiritual reason that Bradbury emphasises above. Speaking of the 'natural' man he says:

Now this man, whilst he is such, and by the light of nature, cannot know the things of the spirit of God. ... The reason is, because they are spiritually discerned, i.e. tried and judged in a spiritual way. Nor can he receive them, so as to love and approve of them; because they are foolishness unto him, absurd and ridiculous. ${ }^{288}$

Watts would agree with these men in the insufficiency of reason, in his allowance of doctrine that is above reason, and of the necessity of the work of the Spirit. However he would overall have a more positive view of reason and the reasonableness of Christian truth.

\section{Summary and conclusion}

Rivers describes two basic tendencies in dissent in the early eighteenth century: that of rationalism and evangelicalism. Rationalism showed itself in liberty of thought and free enquiry with resultant toleration of opinion. The evangelical tendency emphasised traditional reformation doctrines and the centrality of affectionate, experiential religion. ${ }^{289}$

In Watts then we can clearly see both a rational and evangelical side to his work; indeed his aim is to explicitly hold the two together. Watts wished to defend orthodox religion from the critical use of rationalism, especially the threat of deism. So he defends the doctrines of the Trinity, original sin, redemption by Christ, and sanctification by the Spirit; but attempts to do so in accordance with reason. His aim is both apologetic and evangelistic: to fend off accusations, reassure believers, and to call people to faith. In trying to achieve this Watts is at times carried along with the rationalistic flow of his age into areas of comprise, or at least uncertainty, as we saw with regard to the Trinity and soteriology.

\footnotetext{
${ }^{288}$ Ibid., Volume 2, 197-98.

${ }^{289}$ Rivers, Reason, Grace and Sentiment, Vol 1, 165-67.
} 
While presenting these truths as eminently reasonable Watts also creates theological space that allows for religion not to be contained with the confines of reason. Hence he argues for truth above reason, and defends that concept as a reasonable one. In addition the experience of the Christian believer is defended as reasonable, while still bearing the hallmarks of a spiritual encounter with God that transcends purely rational terms.

In this Watts differs from many of his contemporaries. Sell comments that many responses to deism, such as that by Butler, disagreed with the deists' conclusions yet did not differ from them methodologically - the debate remained within the 'rationalistic family. ${ }^{290}$ We have seen that this criticism is also true of Watts but he does add a significant experiential element. In this we can see a way in which Watts bridges the eras of the Puritans and the Evangelical revival.

Within his day Watts clearly falls in the second of the three groups outlined in section 8. That is the group with the largest breadth of opinion in it and Watts is at the more 'conservative' end of the spectrum. While he holds to the reasonability of revelation, in practice he is more likely to hold to a scriptural position that he cannot reconcile with reason than to alter his doctrinal position, although we have noted his rational 'drift' to a more moderate Calvinism and his non-Athanasian position on the Trinity.

It is clear that Locke exercised a great deal of influence over Watts who followed him in numerous areas, especially in natural philosophy. However it was not a slavish following and concerning reason and religion nor was it one with only minor changes. Rather we have seen that his view of the role and potential of reason ends up in a very different place to Locke. In this we have refined the common global comments in the literature that Watts reflects or approximates Locke in his view of reason. ${ }^{291}$

Watts has a far less positive view of the role of reason asserting that it is insufficient to bring us to know God which results in his attack on deistic uses of Locke's framework. For Watts reason's limitation stems from the corruption of human nature by sin,

\footnotetext{
${ }^{290}$ Sell, Dissenting Thought, 86.

${ }^{291}$ For example Yolton, Way of Ideas, 206; Rivers, Reason, Grace and Sentiment, Vol 1, 186.
} 
specifically the influence of sinful passions and desires. Watts' position here has some echoes with the Puritans (see below) but also contains elements of classical thought as articulated by the Cambridge Platonists and, to a lesser extent, the latitudinarians. ${ }^{292}$ The result is that Watts is further distanced from Locke as seen in their disagreement over whether reason would lead anyone to saving faith.

Behind their respective positions lies a difference over the functioning of the will which Watts sees to be free and so able to exercise devastating effect on the mind. Further, while Watts agrees with Locke on some aspects of reason's assessment of revelation, he differs in seeing revelation as constituting true knowledge that is certain in its own right. Watts also argues for a clearly experiential basis to Christian assurance. This is a position that Locke may well have considered an example of 'enthusiasm'.

This view of reason is explanatory of many of Watts' emphasises in a number of his other works. First, as we have noted, the majority of Watts' doctrinal works were written specifically to show the congruence between reason and elements of the Christian faith; or at least to explain why, at times, such congruence cannot be found.

Secondly is his view of the necessity and value of education, and the approach he takes in his educational works. He is clearly a believer in and promoter of education, seen in both his published works and in his involvement in dissenting academies. ${ }^{293}$ His view of reason's important but bounded role is particularly clear in his Essay on Education. ${ }^{294}$ Speaking of our reason Watts says:

Now though nature gives us these powers and faculties, yet it is a good education that must instruct us in the exercise and improvement of them: otherwise like an uncultivated field they will be ever barren and fruitless, or produce weeds and briers instead of herbs and corn. ${ }^{295}$

\footnotetext{
292 Spellman, Locke and Depravity, chapter 3.

${ }^{293}$ Davis, Watts, Chapter 4.

${ }^{294}$ See discussion by Rivers, Reason, Grace and Sentiment, Vol 1, 178-80.

${ }^{295}$ Watts, Works, 'Essay on Education', Volume 5, 362.
} 
Later in this work Watts pictures an example of an ideal upbringing which includes both liberty of thought and encouragement to look for rational proofs, but also orthodox belief and awareness of reason's limits. ${ }^{296}$ The role of education also contributed to his study of astronomy which he thought was eminently suitable for enlarging the capacity of the mind. ${ }^{297}$

Thirdly is Watts' works on toleration and charity. ${ }^{298}$ There is a connection here between epistemology and breadth of orthodoxy. Many in Watts' day, such as Locke, wanted to cut the ground from under dogmatists who were so sure of their position that they would seek to enforce it on others. ${ }^{299}$ As Rogers argues, the epistemological restriction of knowledge was tied to an attitude of tolerance. ${ }^{300}$ Watts sympathises with this but sees that such a move could also undermine both the central tenets of the faith and the assurance of the believer. His carefully delineated view of reason results in a moderate view of toleration that influences both civil government and charity among Christians, while still upholding central orthodoxy and giving grounds for assurance. The focus on charity between Christians runs through Watts' works but is particularly in clear in his work on Orthodoxy and Charity. ${ }^{301}$ Watts limits this charity though to the less clear and disputed points of the faith. ${ }^{302}$

As we outlined in the introduction it is instructive to observe how Watts' position compares to Puritan thought. Comprehensive comparison is not possible and we recognise the diversity of Puritan thought, but some general observations can be made.

\footnotetext{
${ }^{296}$ Ibid., 'Essay on Education', Volume 5, 399-403.

${ }^{297}$ G. P. Brooks, "Mental Improvement and Vital Piety: Isaac Watts and the Benefits of Astronomical Study," Dalhousie Review 65, no. 4 (1985).

${ }^{298}$ Watts, Works, 'Civil Power in Things Sacred', Volume 6; 'Orthodoxy and Charity', Volume 3.

${ }^{299}$ For discussion of Locke's motivations for toleration see Victor Nuovo, Christianity, Antiquity and Enlightenment: Interpretations of Locke (Dordrecht: Springer, 2011), Chapter 10.

${ }^{300}$ G. A. R. Rogers, "Locke and the Latitude-Men: Ignorance as a Ground of Toleration," in Philosophy, Science and Religion in England 1640-1700, ed. Richard Kroll, Richard Ashcraft, and Perez Zagorin (Cambridge: Cambridge University Press, 1992).

${ }^{301}$ Watts, Works, 'Orthodoxy and Charity', Volume 3. Particularly Essay 9 on 'An apology for Christians of different sentiments'.

302 There is a similarity again with Boyle, Wojcik, Robert Boyle, Chapter 4.
} 
Puritan thinking usually allowed that reason gave access to knowledge in earthly things but was much more wary in matters of faith. Reason was regarded as an excellent tool, Christianity was highly rational, and there was overlap between natural theology and revelation; however reason was always regarded as suspect because of its corrupted nature. ${ }^{303}$ So Morgan, in his examination of Puritan thought before 1640 , says that while many accepted that reason could discover some truths that were in Scripture the focus was on the necessity of revelation. ${ }^{304}$ His summary is that there was 'a subordination of human reason to the demands of an enthusiastic faith. ${ }^{305}$ By contrast Watts clearly allows reason a greater authority.

There is more similarity with later Puritans such as Richard Baxter, William Bates, and John Howe. Wallace examines these moderate Calvinists and details their use of natural theology in defending orthodoxy within their 'proto-Enlightenment' age. He argues that they moved to new territory in granting natural theology a much larger role in leading people to orthodox belief. ${ }^{306}$ Baxter examines the potential knowledge from the light of nature and the need for revelation in his work The Reasons of the Christian Religion. This is similar territory to Watts' Strength and Weakness and it reaches similar conclusions: reason should be able to bring someone to knowledge of God and repentance but in practice it does not. Baxter says:

Thence it must needs follow, that it will be but a few that will attain to understand the necessary parts of the Law of Nature aright, by that means alone; and the multitude will be left in darkness still. ${ }^{307}$

For Baxter this is also because of the influence of sin on reason: true reason may have been sufficient but now it is 'darkened, and captivated by sensuality. ${ }^{308}$ Nuttall summarises that while Baxter assigns reason its due place he never gives it primacy. ${ }^{309}$

\footnotetext{
${ }^{303}$ Richard A. Muller, Post-Reformation Reformed Dogmatics: The Rise and Development of Reformed Orthodoxy (Grand Rapids, Mich.: Baker Academics, 2003), Volume 1, 398-402.

${ }^{304}$ John Philip Morgan, Godly Learning: Puritan Attitudes Towards Reason, Learning and Education, 1560-1640 (Cambridge: Cambridge University Press, 1986), 51.

305 Ibid., 309.

${ }^{306}$ Wallace, Shapers of English Calvinism, Chapter 5.

${ }^{307}$ Richard Baxter, The Reasons of the Christian Religion (London: R. White, 1667), 193.
} 
This group also wish to defend Christianity against the charge of irrationalism. Baxter for example says:

What more can be done to the Disgrace and Ruin of Christianity than to make the world believe that we have no reason for it. ${ }^{310}$

Baxter goes on in this section to speak about the reasons to accept Scripture as God's word. We have noted similar statements in Watts above.

Hence with regard to the role of reason we see Watts continuing a trajectory already set in later Puritan thought. In this he takes part in the move that sees reason and revelation as independent and mutually supporting, rather than the older reformed view of revelation serving as a basis for any natural theology. ${ }^{311}$ As a result he sees a place for arguments from natural theology and he strenuously argues for the reasonableness of the faith.

However we also see Watts continue a Puritan emphasis in the necessity of the work of the Spirit to restore right reason. For example Rehnman shows how John Owen grants a limited place to rational arguments to remove prejudice, but does not believe they can be the foundation of faith; rather the work of the Spirit is always needed to overcome the noetic effect of $\sin .{ }^{312}$ Watts' insistence on the necessity of work of the Spirit continues these themes.

However we can also see evidence of Watts occasionally backing away from this position. This is clearest in his call for readers to be 'impartial' and 'unbiased' such that they can see how reasonable his arguments are. Rivers points to Watts' assumption that

\footnotetext{
${ }^{308}$ Ibid., 195.

${ }^{309}$ Geoffrey F. Nuttall, Richard Baxter (London: Nelson, 1965), 124.

${ }^{310}$ Richard Baxter, The Saints Everlasting Rest (London: Rob. White, 1650), Preface to Part II.

${ }^{311}$ See overview by Muller, Dogmatics, Volume 1, 270-310.

${ }^{312}$ Sebastian Rehnman, Divine Discourse: The Theological Methodology of John Owen (Grand Rapids: Baker Book House, 2002), 135-51.
} 
'open-minded enquiry will support truth. ${ }^{, 313}$ Hence Watts has some confidence of people being argued into the faith, while still being negative about the distortion the sinful passions may exercise. David Field points out that Howe and others were far more negative about unbelievers responding to rational argument, because they were, by virtue of their unbelief, being unreasonable. ${ }^{314}$

Watts also echoes Puritan themes in his reliance on the experience of the believer. As we saw above he believes that such Spirit-wrought experience is the ground of assurance, and is in fact of greater strength than rational arguments.

In conclusion we see Watts as something of an 'Enlightenment Puritan': positive about the advances in reasoning in his day and yet carefully circumscribing reason's role in matters of faith. As a result he gives himself to the careful use of logic and promotion of education, he defends the reasonability of the orthodox faith, but also says the Spiritwrought work of God in the heart of the believer is the final source of assurance.

This analysis means we must take issue with a conclusion of Hoyles who says of Watts:

He condemns any zeal which is not subordinate to the understanding. This amounts to a denial of one of the chief characteristics of Puritanism, and reveals that the Dissenters were aligning themselves with the dominant trend of Anglican theology, which claimed that the Enlightenment somehow dispensed Christians from their supernatural sources. ${ }^{315}$

While Enlightenment trends are clear in Watts, a supernatural source is one of the elements he most emphasised and defended. More than this we must conclude that in the final analysis Watts stands against the reason of his age. In an essay on the content of the gospel Watts reflects on the errors that are being multiplied because of a high view of reason. He responds:

\footnotetext{
${ }^{313}$ Rivers, Reason, Grace and Sentiment, Vol 1, 180.

${ }^{314}$ Field, Rigide Calvinisme, 99-103.

${ }^{315}$ Hoyles, Waning of the Renaissance, 186.
} 
Now, perhaps, some may think it the duty and business of the day to temporize, and by preaching the gospel a little more conformably to natural religion, in a mere rational or legal form, to bring it down as near as may be to their scheme, that we may gain them to hear and approve it, or at least, that we may not offend them. But I am rather of opinion, that we should in such a day stand up for the defense of the gospel in the full glory of it's most important doctrines, and in the full freedom of it's grace; that we should preach it in it's divinest and most evangelical form, that the cross of Christ, by the promised power of the Spirit, may vanquish the vain reasonings of men, and that this despised doctrine triumphing in the conversion of souls, may confound the wise and the mighty, and silence the disputers of this world. ${ }^{316}$

${ }^{316}$ Watts, Works, 'Orthodoxy and Charity', Volume 3, 603. 


\section{Chapter 3 The Place of Passion}

\section{Introduction}

\subsection{Orientation and terminology}

The study of the passions in the eighteenth century is an area of great complexity. This stems from a combination of the wide divergence of thought on the topic and the number of associated areas involved in their discussion. The central issues are the place of the passions in people's experience of God, the appropriate government of the passions, the connection between passions and virtue, and social versus private passions. Behind these lie debates on human nature, altruism versus egoism, and the 'good life'. Hence it is an area where moral philosophy and religious experience coincide. ${ }^{1}$

Unlike our discussion on reason there is no one figure, such as John Locke, who dominates the landscape. As a result we will give a brief overview of the issues involved, introducing some of the key figures. We will then describe Watts' position and compare him with his contemporaries as we do so.

Terminology regarding the affections in the eighteenth century is involved because of historical changes and variation between different authors. The inherited tradition from classical thought usually spoke of: (1) appetites, which were purely physical in nature, such as hunger; (2) passions, which involved the physical senses and were passive and involuntary, such as fear; and (3) affections, which did not involve physical senses, and were active and voluntary in nature, such as sympathy. ${ }^{2}$

However the latter two categories became increasingly blurred. Passion often connoted a stronger sensation than affection, but there was great overlap of meaning. This is seen

\footnotetext{
${ }^{1}$ Susan James, "The Passions and the Good Life," in The Cambridge Companion to Early Modern Philosophy, ed. Donald Rutherford (Cambridge: Cambridge University Press, 2006), 198-200.

${ }^{2}$ Dixon, Passions to Emotions, 21-22.
} 
in Johnson's Dictionary ${ }^{3}$ where one of the entries under affection is 'passion of any kind', and includes examples of joy, grief, fear, and anger. An entry under passion is a 'violent commotion of the mind', which suggests its stronger character. However Watts himself is quoted in a later entry where he says that the passions 'signifies any of the affections of human nature such as love, fear, joy, sorrow.' Watts himself says that he uses the terms 'affections' and 'passions' synonymously. ${ }^{4}$

So while appetite continued to refer to the felt needs of the physical body, passion and affection refer, almost synonymously, to heartfelt emotions. We will follow this usage, varying between 'passions' and 'affections' depending on the terminology of the author being discussed. It is worth noting that while the terms 'emotion' and 'feeling' are in many ways the modern equivalents there has been a movement in meaning, allied with a change in view of the functioning of human faculties. ${ }^{5}$

As we have mentioned, discussion on the passions broadens into areas of moral philosophy. Hence terminology of 'moral sense' and 'moral sensibility' are entwined with that of passion and affection. The former usually refers to conscience, the later usually to particular passions which are either self-regarding or social in nature. ${ }^{6}$

\subsection{Background thought}

The early eighteenth century inherited a rich and varied range of ideas with regard to the passions. ${ }^{7}$ Classical thought continued to have a pronounced bearing, particularly that of Aristotle and the belief that the passions were wayward but that reason could appropriately moderate them. ${ }^{8}$ There was also a neo-Stoic view of the suppression of emotion seen for example in Spinoza. ${ }^{9}$

\footnotetext{
${ }^{3}$ Samuel Johnson, A Dictionary of the English Language (London: W. Strahan, 1755).

${ }^{4}$ See section 2.1 below

${ }^{5}$ So the overall argument of Dixon, Passions to Emotions.

${ }^{6}$ Ibid., 64-65.

${ }^{7}$ For a general overview see Susan Sauve Meyer and Adrienne M. Martin, "Emotion and the Emotions," in The Oxford Handbook of the History of Ethics, ed. Roger Crisp (Oxford: Oxford University Press, forthcoming).

${ }^{8}$ James, "The Passions and the Good Life," 206-07.
} 
A distinctly Christian inheritance came through Augustine and Aquinas who reflected a semi-Platonic and an Aristotelian view respectively. ${ }^{10}$ Augustine had made the object of the passions the key to their correctness: all of the passions were reduced to species of love towards different objects. Hence the appropriateness of any passion could be evaluated by the love producing it. ${ }^{11}$ Aquinas' division of the passions was influenced by Aristotelian categories of activity and passivity, but the overall view was one where the intellect controlled the passions such that they became virtuous. ${ }^{12}$ Both these writers drew the previously mentioned distinction between 'passions' and 'affections' as lower and higher order appetites of the body and the mind respectively.

Reformed and Puritan views on the passions included an emphasis on their fallen nature. Views of the pervasiveness of sin resulted in the belief that no amount of right reason could remedy the passions, because reason itself was distorted. Right affections and moral virtue therefore required regeneration and a marked distinction was drawn between worldly and gracious affection, the later only being possible by the work of the Spirit. $^{13}$

The overall seventeenth century view of the passions then was negative. As James says:

That the passions are both wayward and destructive is one of the commonplaces of seventeenth-century thought ... To be passionate is to be blinkered and impressionable, vulnerable and a threat to others. ${ }^{14}$

\footnotetext{
${ }^{9}$ Susan James, "Reason, the Passions, and the Good Life," in The Cambridge History of SeventeenthCentury Philosophy, ed. Daniel Garber, et al. (Cambridge: Cambridge University Press, 1998), 1374-75.

${ }^{10}$ Andrew Tallon, "Christianity," in The Oxford Handbook of Religion and Emotion, ed. John Corrigan (Oxford: Oxford University Press, 2008), 115-16.

${ }^{11}$ Dixon, Passions to Emotions, Chapter 2.

${ }^{12}$ Susan James, Passion and Action: The Emotions in Seventeenth-Century Philosophy (Oxford: Clarendon Press, 1997), Chapter 3.

${ }^{13}$ Richard B. Steele, "Gracious Affection" and "True Virtue" According to Jonathan Edwards and John Wesley, Pietist and Wesleyan studies (London: Scarecrow, 1994), 62-63.

${ }^{14}$ James, "Reason, the Passions, and the Good Life," 1358.
} 
Enlightenment confidence in reason meant a growing move towards seeing right reason as the answer to unruly passions. Allied to this was the classical identification of reason with virtue and hence passion, as antithetical to reason, as associated with vice. James says that it was simply assumed in the seventeenth century that the virtuous life would be lived by reason taking control over the passions. ${ }^{15}$ The weakness of the passions was not only seen to lie in their impetuous nature, but also in the lack of objective and impartial reflection. The passions by their very nature reflect an emotional commitment which makes us blind to its own instinctive reasoning. ${ }^{16}$ This led to a high view of education that aided rationality, but also to the need for self-discipline to master one's passions.

Towards the end of the seventeenth century however there were new voices bringing about what Fiering calls a 'momentous revolution in psychological theory. ${ }^{17}$ Of greatest influence was Descartes' dualistic view of human nature and theories of the physiological mechanisms of the passions. Descartes saw passions as perceptions of the soul in response to stimuli; they were to be embraced as part of the good life, but excess was to be avoided. ${ }^{18}$ Dixon argues that Descartes' views were to result in moving away from an active to a passive view of the passions and a blurring of the traditional difference between lower passions and higher affections. This was connected with a change in view of the human faculties where passions became a separate third faculty rather than being part of the will. ${ }^{19}$ Another revolutionary voice was the third Earl of Shaftesbury whose work we will mention below. As we will see this involved a far more positive view of the passions where they were regarded as auxiliaries of reason or even the leading faculty of the soul.

\footnotetext{
${ }^{15}$ Ibid., 1359.

${ }^{16}$ Ibid., 1362-63.

${ }^{17}$ Norman Fiering, Jonathan Edwards's Moral Thought and its British Context (Chapel Hill: University of North Carolina Press, 1981), 148.

${ }^{18}$ Harold J. Cook, "Body and Passions: Materialism and the Early Modern State," Osiris 17 (2002): 33.

${ }^{19}$ Dixon, Passions to Emotions, 76-79. For in depth discussion of Descartes see James, Passion and Action, Chapter 5.
} 


\subsection{Passions and morality}

The superiority of reasoning and the blind passivity of the passions is where a link with morality is seen. ${ }^{20}$ The fatal flaw of the passions meant many believed that they should not be used as a guide to ethics. The ideal was ethical reasoning which proceeded in a logical manner akin to geometry. So Locke had argued that 'moral Knowledge is as capable of real Certainty, as Mathematicks. ${ }^{21}$ Hence one stream of thought attempted to locate morality on a rationalistic foundation. This natural law view is seen for example in Samuel Clarke's Boyle lectures. ${ }^{22}$

However in contrast to this intellectualist approach Lord Shaftesbury ${ }^{23}$ introduced a defence of natural affection which drew on classical philosophers whom he believed had correctly understood the relation between affections, virtue, and religion. ${ }^{24}$ Rivers says that for Shaftesbury, 'Natural affection which has its origin in the preservation, welfare and support of the species, is the basis of morals. ${ }^{25}$

Shaftesbury had a view of morality akin to that of aesthetic judgements which were natural to us. In this he took a significant step towards moral judgments being affectionate in nature rather than intellectual. ${ }^{26}$ As Potkay says for Shaftesbury, 'joy serves as a naturalistic sanction for moral conduct. ${ }^{27}$ However Shaftesbury said these

\footnotetext{
${ }^{20}$ For an overview of this area see Aaron Garrett, "Seventeenth-Century Moral Philosophy: Self-Help, Self-Knowledge and the Devil's Mountain!," in The Oxford Handbook of the History of Ethics, ed. Roger Crisp (Oxford Oxford University Press, forthcoming).

${ }^{21}$ Locke, Essay, IV.iv.7: 565.

${ }^{22}$ Samuel Clarke, A Discourse Concerning the Unchangeable Obligations of Natural Religion, and the Truth and Certainty of the Christian Revelation (London: W. Botham, 1706). See John Gascoigne, "Science, Religion and the Foundation of Morality," Enlightenment and Dissent 17 (1998).

${ }^{23}$ Anthony Ashley-Cooper, the third Earl of Shaftesbury, 1671-1713.

${ }^{24}$ For background to this see Norman S. Fiering, "Irresistible Compassion: An Aspect of EighteenthCentury Sympathy and Humanitarianism," Journal of the History of Ideas 37, no. 2 (1976).

${ }^{25}$ Rivers, Reason, Grace and Sentiment, Vol 2, 122.

${ }^{26}$ Norman Fiering, Moral Philosophy at Seventeenth-Century Harvard: A Discipline in Transition (Chapel Hill: University of North Carolina Press, 1981), 179-80.

${ }^{27}$ Adam Potkay, The Story of Joy: From the Bible to Late Romanticism (Cambridge: Cambridge University Press, 2007), 96.
} 
natural affections needed to be refined by education and aided by reason. He stood opposed to those who made virtue turn on divine reward or punishment which he believed made virtue selfish. ${ }^{28}$ Rather the affections behind an action were seen to determine its goodness:

Since it is therefore by Affection merely that a Creature is esteem'd good or ill, natural or unnatural; our business will be, to examine which are the good and natural, and which the ill and unnatural Affections. ${ }^{29}$

As Shaftesbury explores this concept the key feature is to what degree any affection is aimed at, and contributes towards, the public good.

Shaftesbury's view of inherent social affections was continued and refined in different ways by Bishop Butler ${ }^{30}$ and Francis Hutcheson ${ }^{31}$. Butler distinguished between selfinterest and particular passions, and argued that self-interest and public good coincide: 'These Ends do indeed perfectly coincide; and to aim at publick and private good are so far from being inconsistent, that they mutually promote each other. ${ }^{32}$ However he also acknowledged a weakness in Shaftesbury's position in not allowing a greater role for rational reflection and conscience. ${ }^{33}$

Butler saw people's propensity to evil stemming from passions which were ungoverned and pursued with resulting injury to others. As private and public good coincide this was also injurious to the indiviual themselves. The problem then is when 'reasonable

\footnotetext{
${ }^{28}$ And so criticises Locke, see B. Jerome Schneewind, "The Active Powers," in The Cambridge History of Eighteenth-Century Philosophy, ed. Knud Haakonssen (Cambridge: Cambridge University Press, 2006), 569.

${ }^{29}$ Lord Shaftesbury, Characteristicks of Men, Manners, Opinions, Times (London: John Darby, 1711), Volume 2, 22.

${ }^{30}$ Joseph Butler, Fifteen Sermons Preached at the Rolls Chapel (London: W. Botham, 1729).

${ }^{31}$ Francis Hutcheson, An Essay on the Nature and Conduct of the Passions and Affections (London: S. Powell, 1728).

${ }^{32}$ Butler, Fifteen Sermons, 5.

${ }^{33}$ Ibid., iv-v.
} 
Concern for themselves, or cool Self-love is prevailed over by Passion and Appetite., ${ }^{34}$ The answer is the dominance of cool, reflective self-love.

Hutcheson argued that we have public as well as private affections, and pursuit of benevolent public affections will result in our own happiness. This flows from our natural moral sense and sense of honour which means we feel pleasure in acting for others. In this Hutcheson was drawing on Shaftesbury's concept of moral sense but also Locke's empirical epistemology in his view of moral sensations. ${ }^{35}$ Fiering says:

It was Hutcheson's conception of these sophisticated sensations - such as those of the moral sense - that revolutionized moral philosophy and aesthetic criticism and placed religious psychology on new foundations, by creating the psychological categories or domains for knowledge independent of ratiocination and intellectual judgements. ${ }^{36}$

Hutcheson believed that if we would but manage our affections with cool and calm reason both virtue and personal fulfilment would be achieved. He differed from Shaftesbury in his view of future divine compensation which he saw as necessary in the pursuit of social virtues, recognising that many virtuous people suffer greatly in their lifetime. $^{37}$

Standing opposed to these views of altruistic human nature stood Bernard Mandeville and his view of how private vices result in public benefits. ${ }^{38}$ This was a new form of the self-interested motivation theory of Hobbes. Mandeville mocked other people's pretensions to virtue and argued that even when everyone acts with their natural selfish

\footnotetext{
${ }^{34}$ Ibid., 23.

${ }^{35}$ Stephen Darwall, "The Foundations of Morality: Virtue, Law, and Obligation," in The Cambridge Companion to Early Modern Philosophy, ed. Donald Rutherford (Cambridge: Cambridge University Press, 2006), 238-39. See also Gascoigne, "Foundation of Morality," 96-97.

${ }^{36}$ Fiering, Moral Philosophy, 203.

${ }^{37}$ Andrew Ward, "Introduction," in On the Nature and Conduct of the Passions with Illustrations on Moral Sense, 1728, by Francis Hutcheson (Manchester: Clinamen, 1999), viii-X.

${ }^{38}$ Bernard Mandeville, The Fable of the Bees: or, Private Vices Publick Benefits (London: J. Roberts, 1714).
} 
passions it still results in the good of society. ${ }^{39}$ It is worth noting that one corollary of Mandeville's views was that he stood against charity schools believing they were not necessary for promotion of morality - an argument to which Watts' writing on charity schools responded. ${ }^{40}$

Hence in discussion of passion two key polarities had emerged: the view of human nature as naturally vicious or virtuous and the related focus of passions as inherently selfish or social. However within the church the virtuous view of social passions whereby people act with benevolence towards others was extremely common. ${ }^{41}$

\subsection{Passions and the good life}

The link between passions and moral philosophy extended to views of the 'good life'. For example Locke assumed that people lived for enjoyment and this enjoyment involved the passions. ${ }^{42}$ For Locke the driving function of our passions was towards the happiness of the individual which was attained by the elimination of 'uneasiness'. This resulted in different sensations, such as joy, sorrow, and fear, depending on the circumstances. ${ }^{43}$ But there were competing views: Hobbes made passions aids to our own preservation, Descartes said they led us to desire what would be useful to us, and Malebranche said they led us to love our bodies and preserve them. ${ }^{44}$ For each of these authors there is a concomitant account of how reason, passions and will relate to each other. These flow from their own particular account of the faculties of the soul, the freedom of will, and decision making. ${ }^{45}$

Shaftesbury saw the living out of our natural affection as the means to the good life and true happiness. He describes it as comprising:

\footnotetext{
${ }^{39}$ Schneewind, "Active Powers," 570.

${ }^{40}$ Davis, Watts, 93-96.

${ }^{41}$ It is seen for example in a Spectator article written by the dissenting minister Henry Grove, The Spectator, 1 September 1714.

${ }^{42}$ Locke, Essay, II.xx.3: 229-30.

${ }^{43}$ Ibid., II.xx.6-18: 230-32.

44 James, "The Passions in Metaphysics," 922.

${ }^{45}$ Ibid., 935.
} 


\begin{abstract}
A Mind subordinated to Reason, a Temper humaniz'd, and fitted to all natural Affection; an Exercise of Friendship uninterrupted; a thorow Candour, Benignity, and Good Nature; with constant Security, Tranquillity, Equanimity... ${ }^{46}$
\end{abstract}

For Shaftesbury this was a return to classical views of morality and religion; in this he parallels the view of the Cambridge Platonists except that he wishes to make morality independent of God. ${ }^{47}$ The result is a view of a virtuous life that brings its own happiness; as Potkay says, 'Virtue, in Shaftesbury's neo-Stoic view, is its own reward, both personally and socially. ${ }^{48}$

Butler later spoke of the happiness and contentment that came from the virtuous life. $\mathrm{He}$ recognised the problem of self-love whereby people sought their own happiness at the expense of others; however he thought the real problem was that self-love does not know what will actually make a person happy: 'Immoderate Self-love does very ill consult its own Interest. ${ }^{49}$ For Bulter enlightened self-love which sought the good of others brought its own reward of happiness.

\title{
1.5 Passions and the Christian life
}

Brinton has shown that the passions were regular topics of early eighteenth century sermons instructing Christians as to the place they should have. ${ }^{50}$ These sermons had a standard shape: they defined and classified the passions, the usefulness of the passions was established against Stoicism, the superiority of reason over the passions was argued, and sinful passion was defined as that which overthrows reason. ${ }^{51}$

\footnotetext{
${ }^{46}$ Shaftesbury, Characteristicks, Volume 2, 434.

${ }^{47}$ Rivers, Reason, Grace and Sentiment, Vol 2, 131-32.

${ }^{48}$ Potkay, Story of Joy, 104.

${ }^{49}$ Butler, Fifteen Sermons, 211-12.

${ }^{50}$ Alan Brinton, "The Passions as Subject Matter in Early Eighteenth-Century British Sermons," Rhetorica 10, no. 1 (1992).

${ }^{51}$ Platonic elements within this are see to be derived from Augustine, and Aristotelian elements from Aquinas.
} 
An example is a sermon by Samuel Clarke on the government of the passions. Clarke sees the passions as requiring the strict guidance of reason:

Herein therefore particularly lies the principal Duty of Man: in keeping his Passions subject to Reason, and in governing his Appetites, by that Understanding wherewith God has distinguished him from the inferior Creation. $^{52}$

Passions are not seen by Clarke as being evil in themselves; rather they are given by God to motivate us. By them we are 'pushed on and excited to be more earnest and vigorous, more constant and diligent in all those Actions of Life, which Reason directs, and the Affections execute. ${ }^{53}$ But when passions rule instead of reason they become sinful, and man becomes like a beast.

There was also consistent criticism of the claims to experience by those labelled enthusiasts. While the prime feature of enthusiasm was laying claim to private revelations, it often also included description of mystical experiences of God. Butler said that the Biblical theme of knowing the love of God had been abused by enthusiasts; however he lamented an over reaction against this of 'reasonable religion', which is 'so very reasonable, as to have nothing to do with the Heart and Affections. ${ }^{, 54}$

A different view of religious experience grew out of Shaftesbury's understanding of the aesthetics of morality. For him a sight of God in his perfect harmony and proportion cannot but result in recognition of his beauty. As Rivers says: 'Contemplation of the beauty of the divine order induces ecstasy and rapture, which Shaftesbury also calls "Religious Affection"... and "Divine Passion". 55 This passion was then seen to be conducive to virtue.

\footnotetext{
${ }^{52}$ Samuel Clarke, The Government of Passion (London: Will. Botham, 1711), 17-18.

53 Ibid., 18.

${ }^{54}$ Butler, Fifteen Sermons, 262.

${ }^{55}$ Rivers, Reason, Grace and Sentiment, Vol 2, 139.
} 


\subsection{Watts' works relating to passion}

Watts wrote only two works specifically relating to the place of passion in the Christian life. These were The Doctrine of the Passions Explained and Improved (1729) and Discourses of the Love of God and the Use and Abuse of the Passions in Religion (1729). The first of these is an exploration of the workings of the passions generally with discussion of their government; the second is an examination of their appropriate place in the Christian life with more guidance on their right use. A related work is Selflove and Virtue Reconciled only by Religion (1739). This addresses the issues of affection and morality mentioned above. However the theme of the passions runs throughout Watts' works, especially in his sermons, as well as his works on education, and his hymns, and so we will also draw on these wider works.

\section{Overview of the passions}

\subsection{Definitions}

Watts mentions the background definition of passions meaning purely passive movements but dismisses this as unrelated to the way the word is used in his day. Instead he says: 'Passions, in this discourse, signify the same with natural affections in general, such as love, hatred, joy, hope, anger, sorrow, etc.' He notes that there are sometimes limited uses where passion refers specifically to anger and affection to love; however he goes on, 'in this discourse we take passion and affection to mean the same thing, and to extend to any of these powers or principles in human nature, which were just mentioned; such as love, joy, etc. ${ }^{56}$

Passions are seen to connote those emotions that have a physical element to them. Watts believes pure spirits have similar 'affections of the mind' as humanity, but not the accompanying physical sensations. The tendency for passions to refer to states that are more physical, and affections for those more mental in nature reflects a longstanding distinction from Augustine and Aquinas. ${ }^{57}$ However while recognising this Watts

\footnotetext{
${ }^{56}$ Watts, Works, 'Doctrine of the Passions', Volume 2, 583.

${ }^{57}$ Thomas Dixon, "Revolting Passions," Modern Theology 27, no. 2 (2011): 300-01.
} 
explicitly equates the two terms. ${ }^{58}$ In his definition of the passions Watts is in the mainstream of early eighteenth century Christian thought.

\subsection{The working of the passions}

Watts describes the production of the passions as follows:

They are those sensible commotions of our whole nature, both soul and body, which are occasioned by the perception of an object, according to some special properties that belong to it. ${ }^{59}$

The properties in question are those of rarity, goodness or evil. These result in corresponding passions of wonder, love and hate. Wonder is discussed briefly but it is love and hate which are dominant in Watts' discussion. Watts says these are the primary passions which then result in second order passions which are variants on them such as like or dislike, esteem or contempt. These then bring about numerous derivative passions dependent on circumstances: if an object is good and brings my liking of it I will feel joy if I have it, desire if I do not, or sorrow if it is lost. ${ }^{60}$ In this Watts is very similar to traditional taxonomies of the passions.

Watts sees our passions as dependent on the mixed nature of mankind i.e. comprising soul and body. Passions involve 'some ferments of the bloud or natural spirits, or some alterations which affect the body, as well as we feel special impressions on our minds. ${ }^{61}$ In his comment on movements of the blood Watts is true to the physiological understanding of his time. ${ }^{62}$ He mentions Descartes' explanation but says he has chosen not explore the physiological basis behind our passions. ${ }^{63}$

\footnotetext{
${ }^{58}$ For an argument that Watts does not actually mean this but rather distinguishes between affections as ideal and passions as sinful see Louise Joy, "Literary Affections: Categorization of the Emotions in Eighteenth-Century Writing" (University of Cambridge, 2007), Chapter 1.

${ }^{59}$ Watts, Works, 'Doctrine of the Passions', Volume 2, 584. Brinton says that such Aristotelian sounding descriptions were standard in the early eighteenth century, Brinton, "Passions," 59.

${ }^{60}$ Watts, Works, 'Doctrine of the Passions', Volume 2, 584-85.

${ }^{61}$ Ibid., 'Doctrine of the Passions', Volume 2, 586.

62 John Corrigan, "'Habits from the Heart": The American Enlightenment and Religious Ideas about Emotion and Habit," The Journal of Religion 73, no. 2 (1993): 184.
} 
So for Watts the passions are felt because of our physical nature. The result is that there is always an accompanying physical sensation for any passion. This is because there is:

...such a near and special union between soul and body, that there are very few operations or affections of the mind, which do not receive a sensible turn or influence from the qualities and ferments, the impressions, powers, and passions of flesh and bloud. ${ }^{64}$

For example he says that if we love God it is impossible in our present physical state that we would 'feel no sensible workings of fear and hope, desire or anger, in correspondence with this holy passion. ${ }^{65}$

We saw in the previous chapter that Watts viewed reason as the primary ruling faculty in mankind. ${ }^{66}$ This is made explicit in his comments on the passions: in one of his sermons Watts speaks of the original design of Adam before the fall and gives a picture of how the faculties of the soul were supposed to work. He says:

...his reason was the guide to all his meaner faculties, and his appetites and his affections in a sweet harmony followed the conduct of his reason: And as his understanding and judgment put forth their regular dictates, so the meaner powers paid a constant obedience, and pursued their proper objects. ... His natural powers had no uneasy contest, there was no civil war nor rebellion amongst them to interrupt his happiness. ${ }^{67}$

We notice the primary role of reason in guiding the passions, which is repeated at various points throughout Watts' works. This is key to Watts' view of the effect of sin and also the recovery of salvation. We also notice the happiness enjoyed when the human faculties are working in correct order; this will be seen again in the pleasure brought through recovery of that harmony in salvation.

\footnotetext{
${ }^{63}$ Watts, Works, 'Doctrine of the Passions', Volume 2, 586.

${ }^{64}$ Ibid., 'Evangelical Discourses', Volume 2, 105.

${ }^{65}$ Ibid., 'Love of God', Volume 2, 656.

${ }^{66}$ See chapter 2 , section 2.4

${ }^{67}$ Watts, Works, 'Sermons', Volume 1, 9.
} 
This view of the original working of reason and passion is seen in other writers. For example John Tottie ${ }^{68}$ preached a sermon at St Paul's on A View of Reason and Passion as in their Original and Present State. On Adam he said, 'one great perfection of his nature consisted in this, that the inferior faculties were uniformly regular in obedience and subordination to the supreme.' He goes on to present a picture of harmony in Adam's powers and his resulting happiness. One of Tottie's conclusions is that passions are not to be regarded as evil but rather were designed as 'springs of action and inlets of pleasure. ${ }^{69}$

In discussing control of the passions Watts admits that because passions are made up of physical effects as well as mental operations they are not under the direct control of the will. He says, 'we cannot stir up and suppress these ferments of animal nature by a sovereign act of volition when we please. ${ }^{70}$ However Watts also sees an interaction between the faculties: while reason has a primary place in affecting passions, he also says that passions have 'a reflexive influence on the mind and the will. ${ }^{71}$ Raised affections towards an object impress it more strongly on the mind, and conform the will towards it.

Dixon sees the influence of Descartes as foundational here: he says that Watts 'used the Cartesian model of perceptions with bodily causes (rather than movements of the appetite or will) in understanding the passions. ${ }^{72}$ As a result Dixon views Watts' position as an early example of movement away from the traditional Christian voluntarist view which had made the will the primary source of the passions.

This is complicated however by the classic voluntarist distinction between lower and higher functions of the will termed passions and affections respectively. As we have

\footnotetext{
${ }^{68}$ A fellow of Worcester College, Oxford.

${ }^{69}$ John Tottie, A View of Reason and Passion, as in their Original and Present State (London: C. Rivington, 1738), 5-7.

${ }^{70}$ Watts, Works, 'Doctrine of the Passions', Volume 2, 609.

${ }^{71}$ Ibid., 'Love of God', Volume 2, 699.

${ }^{72}$ Dixon, Passions to Emotions, 78.
} 
seen Watts blends these two areas, which seems to go hand in hand with his making the passions partially passive and partially active.

In addition, as we will see below, Watts does speak of how we can and should govern our passions and so believes they can at least be influenced. Further Watts does not reduce the passions to merely passive sensations; instead he calls the passions 'active and sprightly powers' because, he states, many involve the will and few are entirely passive. ${ }^{73}$ For example in describing what is involved in the love of God Watts says, 'It implies a choice of him above and beyond all things else, as our most desirable portion and our eternal good. ${ }^{74}$ In this sense Watts is continuing elements of the older tradition in seeing our affective faculty as part of, or at least linked with, our will. ${ }^{75}$ However he is also at least partially adopting Cartesian categories and definitions in the working of the passions.

This is also seen in Watts' view of the faculties of the soul. He often gives a traditional two faculty view of understanding and will, where they are the "chief faculties ${ }^{76}$ or the 'ruling faculties ${ }^{, 77}$ of the soul. This means he speaks of the passions as part of the 'lower faculties' under the control of the higher faculties of understanding and will. ${ }^{78}$ When speaking this way passion is allocated a place with sense and appetite reflecting an Aristotelian and Thomist view. However he also gives a three faculty view where the passions are added as independent of the will. So he speaks of man's 'faculties of understanding, will and affection. ${ }^{, 79}$ In this sense he reflects developments of his day which gave passions a far higher place within the human psychology. We will return to this somewhat mixed picture in our conclusions.

\footnotetext{
${ }^{73}$ Watts, Works, 'Doctrine of the Passions', Volume 2, 586.

${ }^{74}$ Ibid., 'Love of God', Volume 2, 642.

${ }^{75}$ Watts is echoing elements of Augustine's view for example Saint Augustine, The City of God Against the Pagans, ed. R. W. Dyson (Cambridge: Cambridge University Press, 1998), XIV.6.590.

${ }^{76}$ Watts, Works, 'Dissertations', Volume 6, 595.

${ }^{77}$ Ibid., 'Love of God', Volume 2, 704.

${ }^{78}$ Ibid., 'Ruin and Recovery', Volume 6, 188-89.

${ }^{79}$ Ibid., 'Ruin and Recovery', Volume 6, 206, 92.
} 
The nature of the passions as a mixed phenomenon involving soul and body leads Watts to make a variety of comments as to their variation between people and over time. He speaks of the variation caused by the disposition of different personalities and the differences between nationalities. He also describes the various affects of age, of seasons of the year and times of the day, of the weather, of illness versus health, of nervous diseases and of other conditions of life. ${ }^{80}$ In his second main work on the topic these variations are used to give pastoral advice and comfort to those who feel lacking in their love of God. ${ }^{81}$

\subsection{The purpose of the passions}

For Watts the passions main purpose is related to motivation. He says that for our period of time in the flesh we are given passions to 'assist the feeble influences of our reason in the practice of duty, for our own, and our neighbour's good. ${ }^{82}$ Again:

Consider, my friends, what were the passions made for? Not merely for the sensible pleasure of human nature, but to give it vigour and power for useful actions. $^{83}$

There is seen to be benefit both to the body in self-preservation and to the mind in assisting it in its decisions. Watts focuses on the second of these, seeing the need for passions as stemming from a weakness in our reason. So he says, 'Reason is too slow, and too weak, to excite a sudden and vigorous activity in many cases; but passion is sudden and strong for this purpose. ${ }^{, 84}$ This continues a Puritan view of the passions as supplementing the motivational weaknesses of reason. For example Baxter says, 'Reason is a sleepy half-useless thing, till some Passion excite it. ${ }^{95}$

\footnotetext{
${ }^{80}$ Ibid., 'Doctrine of the Passions', Volume 2, 603-04.

${ }^{81}$ Ibid., 'Love of God', Volume 2, 701-02.

${ }^{82}$ Ibid., 'Doctrine of the Passions', Volume 2, 605.

${ }^{83}$ Ibid., 'Love of God', Volume 2, 689.

${ }^{84}$ Ibid., 'Doctrine of the Passions', Volume 2, 605.

${ }^{85}$ Richard Baxter, Poetical Fragments: Heart-Imployment with God and It Self (London: T. Snowden, 1681).
} 
For Watts it is not that the passions play any part in deciding what is good and evil which is the role of reason. In fact use of the passions for this purpose will only result in confusion:

The passions never clear the understanding, but raise darkness, clouds and confusion in the soul: Human nature is like water which has mud at the bottom of it, it may be clear while calm and undisturbed, and the ideas, like pebbles, appear bright at the bottom; but once it is stirred and moved by passion, the mud rises uppermost, and spread confusion and darkness over all the ideas. ${ }^{86}$

In addition the passions have a magnifying effect on the judgement of the mind: 'all the passions derived from love or hatred tend to represent the good or evil of the object to be greater or more important than it really is.' And so Watts concludes, 'the passions are not fit to be our guides in determining truth and falsehood; they were never given us to search out the true nature of things, or to judge concerning their qualities, or the degree of them. ${ }^{87}$

Judgements must be made impartially and for Watts the passions are never impartial; they are always swayed to whichever side they have first leaned because of the perceived good or evil of the object in question. So those who follow their passions will rarely judge or reason correctly because, 'they put themselves under the biass of these powerful commotions of nature, which all lean to one side, and thereby they fall into perpetual prejudices and mistakes. ${ }^{88}$ This leads Watts to repeatedly warn students to establish the truth clearly in their minds before they engage their passions on a subject. ${ }^{89}$ The exception is if the passion is orientated to the discovery of truth itself, in which case it will rightly spur the student on in pursuit of truth. In this case, 'Passion is then refined and consecrated to its divinest purposes. ${ }^{90}$

\footnotetext{
${ }^{86}$ Watts, Works, 'Improvement of the Mind', Volume 5, 330.

${ }^{87}$ Ibid., 'Doctrine of the Passions', Volume 2, 608.

${ }^{88}$ Ibid., 'Doctrine of the Passions', Volume 2, 608.

${ }^{89}$ Ibid., 'Improvement of the Mind', Volume 5, 290-91.

${ }^{90}$ Ibid., 'Improvement of the Mind', Volume 5, 263.
} 
In summary the passions are good when used rightly, that is in being directed by reason, and their main function is motivational. ${ }^{91}$ The passions for Watts:

.... are those lively, warm and vigorous principles and powers in our nature, which animate us to pursue the good, and avoid the evil; and that with vastly greater speed and diligence than the mere calm and indolent dictates of reason would ever do. ${ }^{92}$

In this Watts is in the mainstream of Christian thinking of his day.

This view of the passions as our 'active powers' is seen in Watts' hymns. In a hymn on the topic of spiritual sloth Watts writes:

Lord, shall we lie so sluggish still,

And never act our parts!

Come, holy dove, from th' heav'nly hill,

And sit and warm our hearts.

Then shall our active spirits move,

Upwards our souls shall rise;

With hands of faith, and wings of love,

We'll fly and take the prize. ${ }^{93}$

\section{Self-love and love of others}

\subsection{Social passions}

Watts enters the discussion about moral sentiment in his Philosophical Essays and explores in what sense we have an innate moral disposition. He is willing to talk about the reality of 'moral sense' but is cautious over its definition and use. In speaking of how we know what is right and wrong he prefers to speak of mankind's instinctive moral awareness as being part of our rational ability. Hence he says:

\footnotetext{
${ }^{91}$ See the similar presentation by Rivers, Reason, Grace and Sentiment, Vol 1, 188-89.

${ }^{92}$ Watts, Works, 'Doctrine of the Passions', Volume 2, 608.

${ }^{93}$ Ibid., 'Hymns', Volume 4, 208.
} 
...there is such a thing which may be called a moral sense in the mind, which inclines the man to judge aright... But this moral sense is still the same thing, is the very nature and make of the mind; it is intelligence or reason itself. $^{94}$

He does however also allow for a moral sense in the form of a "pathetic instinct or disposition towards goodness.' He sees this as part of God's original creation of mankind, but, as we will see below, Watts regards these social affections as severely wounded by sin.

The moral sense is also picked up in Watts' discussion of the passions. He sees affections as directed towards love of ourselves or towards the love of others: 'selfish' and 'social' passions respectively. ${ }^{95}$ The social passions include pity, compassion and sympathy, as well as those exercised within certain relationships such as love between spouses and parents and children. Watts says these passions are so that we will to do good to others. He explains:

It was therefore wisely ordered by the God of nature that there should be some principles wrought in us of the affectionate kind, in order to make our mutual services to each other easy and delightful, and to awaken us to the vigorous and unwearied practice of those duties towards our fellow creatures, for which perhaps reason and conscience might have too feeble influence in our present state. ${ }^{96}$

We note here the distinction between this moral sense and both reason and conscience, which is a role of the passions identified by the moral sentimentalists. In discussing the affection of benevolence Watts mentions Hutcheson and his categorisation of 'public passions and affections' and says he makes 'several agreeable and just remarks upon them. ${ }^{97}$ He also later comments approvingly on Bishop Butler's sermons on affections towards others. ${ }^{98}$

\footnotetext{
${ }^{94}$ Ibid., 'Philosophical Essays', Volume 5, 551.

${ }^{95}$ Ibid., 'Doctrine of the Passions', Volume 2, 607.

${ }^{96}$ Ibid., 'Doctrine of the Passions', Volume 2, 607.

${ }^{97}$ Ibid., 'Doctrine of the Passions', Volume 2, 595.

${ }^{98}$ Ibid., 'Doctrine of the Passions', Volume 2, 599.
} 
Watts then clearly stands against the egoists such as Hobbes and Mandeville where social passions are purely the exercise of private vices. This leads Hoyles to says that Watts has no quarrel with Shaftesbury's moral sense as such; rather it is the use to which Shaftesbury puts it that irks him. ${ }^{99}$ We will return to this below.

\subsection{The place for rewards}

While Watts echoes these themes of social passions he sets them in a different context with regard to future rewards. Here we briefly consider his work Self-love and Virtue in which he discusses the place of self-love and its relationship with social duties.

Watts says, 'It is fit a rational being should seek it's own general, ultimate, or supreme happiness'; and also that there is a fitness in 'social virtue'. ${ }^{100}$ However, he observes, these two interests may compete with and contradict each other. The answer lies in obedience to God whereby we obey his commands towards social duties. However in so doing we are always acting towards our own ultimate best interest because God will reward our obedience: 'He has inseparably united our duty and our best interest.' 101

Watts sees this as a fundamental way in which God has made us to live:

Since God has inwrought in our frame such active principles as hope and fear of gaining or losing this happiness, there is abundant reason, from the light of nature, to conclude, that he did not make all these supreme passions about happiness in vain; nor to obstruct our virtue, but to encourage and promote it; and consequently that he will be a rewarder as well as a commander of it. ${ }^{102}$

So while Watts happily speaks about social passions he ties them to future rewards and punishments in exactly the way Shaftesbury was opposed to. Rivers says Shaftesbury argued that, 'This mercenary kind of religion promotes the use of self-love and self-

\footnotetext{
${ }^{99}$ Hoyles, Waning of the Renaissance, 170-71.

${ }^{100}$ Watts, Works, 'Self-love and Virtue', Volume 3, 716-17.

${ }^{101}$ Ibid., 'Self-love and Virtue', Volume 3, 724.

${ }^{102}$ Ibid., 'Self-love and Virtue', Volume 3, 724.
} 
interest at the expense of the social affections. ${ }^{103}$ Watts discusses those like Shaftesbury who believe that divine recompense makes virtue 'selfish and mercenary', and who believe we should practice virtue only because of its 'own rational excellency and loveliness.' His reply is that this not the way scripture speaks about virtue, and it is ineffectual in practice. ${ }^{104}$ This is another area in which he agreed with Locke. ${ }^{105}$

Without the presupposition of God and his recompense Watts maintains that 'there is no possible security to innocence, and there will be no sufficient obligation to social virtue and justice among men. ${ }^{106}$ Hence while social affections exist for Watts they only find their place within his wider theological framework.

Watts addresses this issue as an example of argumentation in The Improvement of the Mind. He addresses Shaftesbury under the title 'Rhapsodus ${ }^{107}$, who argues that, 'neither the fear of future punishment nor the hope of future reward can possibly be called good affections.' Watts responds:

Pray Rhapsodus, tell me, if every man in this present life, by the violence of some counter working passion may not have his good affections to virtue controlled or overcome? May not therefore his eternal fears and hopes be a great advantage, security and support to virtue in so dangerous a state and situation, as our journey through this world towards a better?

He goes on to argue that much as Shaftesbury may 'declaim aloud on the praise of social virtue and the amiable qualities of goodness', he will find that people's passions are too wild to be restrained by such 'mild and silken language.' Indeed he says: 'You

\footnotetext{
${ }^{103}$ Rivers, Reason, Grace and Sentiment, Vol 2, 135.

${ }^{104}$ Watts, Works, 'Self-love and Virtue', Volume 3, 725.

${ }^{105}$ Locke, Essay, II.xxi.70: 281-82.

${ }^{106}$ Watts, Works, 'Self-love and Virtue', Volume 3, 726.

${ }^{107}$ Picking up on Shaftesbury's piece entitled, 'The Moralists, a Philosophical Rhapsody', Shaftesbury,

Characteristicks, Volume 2, 180. Watts refers to the 'rhapsodies called the characteristics'; and comments negatively on it, Watts, Works, 'Improvement of the Mind', Volume 5, 214.
} 
may as well build up a fence of straw and feathers to resist a canon-ball.' However, 'an eternal heaven and an eternal hell carry divine force and power with them.'108

As mentioned above Hutcheson does allow for future rewards. He sees that they are necessary because of the experience of those who have lived moral but unhappy lives. ${ }^{109}$ Having explored the ways in which experience of evil can be for our good under the care of a benign deity and lead to our future eternal happiness, Hutcheson summarises:

May not all the present Disorders which attend this State of prevalent Order, be rectified by the directing Providence in a future Part of our Existence? This Belief of a DEITY, a PROVIDENCE, and a future State, are the only sure Supports to a good Mind. ${ }^{110}$

However even though Hutcheson insists on the need for a future state, it is by way of compensation when he sees his view of the good life now not working. There is a contrast in Watts for whom there is a full-blooded view of reward and punishment at work. Hence we see Watts' agreement with the moralists over the presence of social affections, but for Watts they only have any power when attached to the wider Christian message. $^{111}$

\footnotetext{
${ }^{108}$ Watts, Works, 'Improvement of the Mind', Volume 5, 242-44. For examples of positive reaction to Shaftesbury see Isabel Rivers, "Shaftesburian Enthusiasm and the Evangelical Revival," in Revival and Religion since 1700: Essays for John Walsh, ed. Jane Garnett, H. C. G. Matthew, and John Evangelist Walsh (London: Hambledon, 1993).

${ }^{109}$ Ward, "Introduction," x.

${ }^{110}$ Hutcheson, Passions, 123.

${ }^{111}$ For more on self-love and its relationship to the love of God see Stephen G. Post, Christian Love and Self-Denial: An Historical and Normative Study of Jonathan Edwards, Samuel Hopkins, and American
} Theological Ethics (Lanham: University Press of America, 1987). Bruce W. Davidson, "The four faces of self-love in the theology of Jonathan Edwards," Journal of the Evangelical Theology Society 51, no. 1 (2008). 


\section{The passions and sin}

\subsection{The disorder created by sin}

A key issue for all discussions of the passions is the way in which they have been affected by the sinfulness of humanity. Watts says that the passions were designed for the service of our minds and bodies but in our fallen state they now often prove 'our snares and our torments. ${ }^{, 12}$ In so doing he reflects the traditional view of the dangerous nature of the passions.

For Watts the passions are at the heart of the disorder brought by sin. We saw in the previous chapter that Watts defined Adam's sin as a moment of sinful passion overturning right reason. In Eden Adam had a choice 'to use his understanding well in governing his sense, appetite and passion, or to abuse his understanding, and darken and weaken it by giving the reigns to sensuality and his meaner powers. ${ }^{113}$ Having chosen the later the passions of sinful humanity continue to override any right understanding reason may have and this is the source of our bondage to $\sin$. So in considering our parlous state before God, Watts says:

By nature we are enemies to God and goodness; our own reasonings, our moral motives, our rules of philosophy, and all our self-invented methods of austere penance of mortification, will not wean our hearts from the love of sin and vanity, and work that supreme love to God in our souls, and that delight in him above all things, which is necessary in order to true happiness. $^{114}$

So the right ordering of our faculties has been overturned, and rather than being governed by reason our passions have become a 'most powerful engine of mischief' which lies in the hands of Satan. ${ }^{115}$ The result is that the passions lead people into sinful behaviour: they become 'the springs and occasions of much mischief and misery.' In fact left to themselves they will reduce us to animals:

\footnotetext{
${ }^{112}$ Watts, Works, 'Doctrine of the Passions', Volume 2, 606.

${ }^{113}$ Ibid., 'Ruin and Recovery', Volume 6, 228.

${ }^{114}$ Ibid., 'Caveat against Infidelity', Volume 2, 483.

${ }^{115}$ Ibid., 'Love of God', Volume 2, 669.
} 
Ungoverned passions break all the bonds of human society of peace, and would change the tribes of mankind into brutal herds, or make the world a mere wilderness of savages. Passion unbridled, would violate all the sacred ties of religion, and raise the sons of men in arms against their creator.

Where passion runs riot, there are none of the rights of God or man secure from it's insolences. ${ }^{116}$

The passions not only lead to sinful behaviour but many of the passions are themselves vices such as pride or envy. ${ }^{117}$ Watts later clarifies that no passion is actually evil in and of itself but rather 'if a passion be let loose on an improper object, or in an improper time or degree, or for too long a continuance, then it becomes criminal and obtains sometimes a distinct name., 118

As passions for Watts flow from what we judge to be good and evil, he sees sinful passions as coming from wrong judgements. So he says:

The true reason why the multitudes of mankind become so sinful and so miserable, by fixing their passions on improper objects, or by raising them to excessive degree, is because they are guilty of perpetual mistakes in their judgment, of what is evil and what is good, as well as about the several degrees of good and evil. ${ }^{119}$

This fits with what we saw in the previous chapter where reason is overturned by sinful passions. The result is that we love earthly things above God and so live for them rather than for him. Watts speaks about the control unruly passions exert over us in one of his poems:

Our hasty wills rush blindly on

Where rising passion rolls,

And thus we make our fetters strong

\footnotetext{
${ }^{116}$ Ibid., 'Doctrine of the Passions', Volume 2, 581.

${ }^{117}$ Ibid., 'Doctrine of the Passions', Volume 2, 577.

118 Ibid., 'Doctrine of the Passions', Volume 2, 608.

${ }^{119}$ Ibid., 'Doctrine of the Passions', Volume 2, 610.
} 
To bind our slavish souls. ${ }^{120}$

Similarly a poem on God's rule reflects on our rebellion:

While my wild passions rage within,

Nor thy commands obey;

And flesh and sense, inslav'd to sin,

Draw my best thoughts away. ${ }^{121}$

\subsection{Sinful passions and the body}

Watts see humanity as being constituted with two distinct elements: an 'animal body and rational mind. ${ }^{, 122}$ As we have seen he views passions as stemming from this composite nature of humanity, and at times he seems to locate sin itself within the physical body. This is most pronounced in his sermons on 'flesh and spirit', and his essay on the Powers and Contests of Flesh and Spirit.

In the later work Watts says that the motions of the body are an instinctive part of animal nature and so are not sinful in themselves, they are 'pure operations of brutal matter.' The problem comes when 'the soul or the will indulges them, or approves them, commands them, or complies with them. ${ }^{123}$ While he gives some credence to the corrupt nature of the soul his whole argument is that the soul sins because of the temptations of the flesh i.e. the physical body. He says, 'the flesh, with its affections and appetites towards fleshly objects, is the chief spring and occasion of $\sin$. $^{124}$

This is seen in Watts' discussion of other topics. For example when discussing the incarnation Watts says that Jesus' physical body, which came from Mary, was 'purified from any inherent vicious ferments, which might reside in the animal nature of the

\footnotetext{
${ }^{120}$ Ibid., 'Horae Lyricae', Volume 4, 370.

${ }^{121}$ Ibid., 'Horae Lyricae', Volume 4, 356.

${ }^{122}$ Ibid., 'Ruin and Recovery', Volume 6, 187.

${ }^{123}$ Ibid., 'Flesh and Spirit', Volume 2, 106.

${ }^{124}$ Ibid., 'Flesh and Spirit', Volume 2, 108.
} 
virgin. ${ }^{, 25}$ Also in discussing death one of the blessings that it brings is seen to be the release from the physical body:

At the hour of death the spirits of the just leave all the natural and sinful infirmities of flesh and bloud behind them which are the causes and springs of a thousand imperfections. ${ }^{126}$

And so in discussing heaven Watts speaks of there being no danger of sin because of 'the influences of corrupt flesh and bloud. ${ }^{127}$ Elsewhere Watts speaks in Platonic terms of the body being the prison house of the soul, such as in the following poem:

How meanly dwells th' immortal mind!

How vile these bodies are!

Why was a clod of earth design'd

$\mathrm{T}^{\prime}$ inclose a heav'nly star? ${ }^{128}$

In this way Watts echoes themes of the Cambridge Platonists; these have also been noted in the thought of John Howe whom Watts admired. ${ }^{129}$

However other elements of Watts' thought counter this negative view of the body and the physical nature of the passions. First, as we mentioned above, Watts believes pure spirits experience affections despite not having a body. These are different to our experience of passions, 'yet there is something a-kin to them, which may be called affections in the very nature of every intelligent creature. ${ }^{130}$ In a similar way Watts refers to God experiencing affections which again are different to but related to our passions. ${ }^{131}$ Hence passions are not viewed as negative in themselves, but only as affected by $\sin$.

\footnotetext{
${ }^{125}$ Ibid., 'Ruin and Recovery', Volume 6, 253.

${ }^{126}$ Ibid., 'Ruin and Recovery', Volume 6, 187.

${ }^{127}$ Ibid., 'The World to Come', Volume 1, 658.

${ }^{128}$ Ibid., 'Horae Lyricae', Volume 4, 363. See similar sentiments in ibid., 'Reliquiae Juveniles', Volume 4, 493, 554-55, 69-70.

${ }^{129}$ Field, Rigide Calvinisme, 116-18.

${ }^{130}$ Watts, Works, 'Love of God', Volume 2, 671.

${ }^{131}$ Ibid., 'Doctrine of the Passions', Volume 2, 592.
} 
Secondly Watts speaks of the resurrection body to be enjoyed in the new creation:

When God first united these two pieces of his workmanship, the soul and body, and composed a man, he designed him the subject of various pleasures, wherein each part should have been subservient to the other, to render the felicity of the creature perfect. It is sin and death that have entered into our natures, and prevented this noble design in our present state: but the counsel of the Lord shall stand. ${ }^{132}$

So Watts speaks of the delights to be enjoyed in our new physical bodies. The poem quoted above on the soul being enclosed in an earthly body goes on to speak of the eternal body God has planned. Hence Watts locates sinful passions in the physical nature of mankind, and yet remains positive about both the passions and the body.

\subsection{Summary and comparison}

Watts sees sin as corrupting human nature in a very specific way: it has overturned the harmony of reason, passion and will, such that sinful passions have taken a dominant place. The result is that we desire wrong objects, or desire right objects the wrong amount. Above all we are desirous of things other than God whom we should love above all.

In this Watts shows similarities and differences to other writers of his day. Samuel Clarke speaks of the disordering of passions when they take the place of reason; however his strong intellectualist view shows his even higher view of reason: 'And Man, who when Reason governs him, is the Image of God; degenerates, by the Dominion of Passion, even below the Nature of a Beast. ${ }^{, 133}$

Watts' position gets close to viewing sin as located within the physical body itself but never does so definitively. In this Watts reflects the tendency to Platonic dualism that

\footnotetext{
${ }^{132}$ Ibid., 'Flesh and Spirit', Volume 2, 148.

${ }^{133}$ Clarke, Government of Passion, 19.
} 
runs through Christian thought and is often sourced to Augustine. ${ }^{134}$ However as Dixon points out in Augustine himself this tendency to dualism is countered by seeing the disordered soul as the cause of evil, not the flesh itself. ${ }^{135}$ Watts shows a similar ambiguity and caution in locating sin purely in our physicality.

Watts' view of the effects of sin means he is in a very different position to the moral sentimentalists such as Butler. As we saw above Butler believed man's instincts towards private and public good coincided. This stems from a much more positive view of human nature: Butler viewed human nature as being adapted to virtue as a watch is adapted to measure time. Hence mankind's problem lay in ungoverned passions because of our misunderstanding what was in our best interests. ${ }^{136}$ Butler himself admits that in this he is presenting a 'different Draught of Humane Nature from what we are often presented with. ${ }^{137}$

Watts by contrast sees mankind as in the grip of sin such that passions will be orientated in a sinful direction. He does speak of social passions as we noted above; however these are seen to be only the remnants of our original design:

These things are some ruinous remains of that goodness, virtue or piety which was natural to innocent man, and are partly wrought, perhaps, into his animal nature, as well as in his soul: These instincts are certain relics of a spur to duty, and a bridle to restrain from vice. ${ }^{138}$

Watts will not allow for these social passions to take a leading role. Indeed Watts believes if our moral sense was left entirely to our instinctive affections then we would be left 'at very great uncertainty.'

Hence while finding a place for the moral sense Watts positions himself against the sentimentalists and much closer to the rationalists. However we should note that he also

\footnotetext{
134 Tallon, "Christianity," 115.

${ }^{135}$ Dixon, Passions to Emotions, 33.

${ }^{136}$ Butler, Fifteen Sermons, xi, 18-19.

${ }^{137}$ Ibid., 16.

${ }^{138}$ Watts, Works, 'Philosophical Essays', Volume 5, 551.
} 
differs from rationalists who saw morality as located entirely in natural law as distinct from God. For Watts morality does not lie in the 'abstracted nature of things' but in God himself. ${ }^{139}$ Hence revelation is needed to clarify and reinforce whatever our reason may make out regarding morality. ${ }^{140}$ Within the ethical challenges of his day then Watts acknowledged both moral sense and natural law, but ultimately remains conservatively orthodox in stressing the effects of sin on the passions and on reason. ${ }^{141}$ As a result he believes we require both revelation and regeneration, as we will now see.

\section{The passions in the Christian life}

\subsection{The passions and conversion}

Watts sees conversion as primarily involving faith in Jesus Christ. In one of his Evangelical Discourses he speaks of faith as being a 'looking' to Jesus. However this looking must involve an affect on the passions for it to be true faith. So he says:

It must be such a look as immediately affects the heart with love and sorrow; sorrow for our own sins, and love to Christ our saviour.... You have never seen Christ, as your saviour, if your sins are not the objects of your shame and sorrow; or if Jesus be not the object of your desire and love. ${ }^{142}$

However Watts would differentiate this from the necessity of an emotional conversion. In writing to Benjamin Colman in Boston he speaks about the ministry of John and Charles Wesley. He comments negatively on their 'preaching up the necessity of sensible feelings of our regeneration. ${ }^{143}$ He later refers to the error of the Methodists in their view of "inward feelings of all-converting grace. ${ }^{\text {, }} 44$

The work of conversion though also changes the working of the passions. So Watts says that regeneration involves, 'a great and holy change, wrought in the powers of your

\footnotetext{
${ }^{139}$ Ibid., 'Sermons', Volume 1, 795.

${ }^{140}$ Sell, Philosophy, 59-60.

${ }^{141}$ Ibid., 96-98.

${ }^{142}$ Watts, Works, 'Evangelical Discourses', Volume 2, 53-54.

${ }^{143}$ Watts, "Letters," 375. The other areas listed include election and Christian perfection.

${ }^{144}$ Ibid., 398.
} 
soul, your understanding, will and affections, by the Spirit of God. ${ }^{145}$ This introduces a new delight in spiritual things and of God himself. In one of his sermons Watts puts these words into the mouth of the new convert:

Once, says he, I had no delight in spiritual things; I had no relish of spiritual pleasures; but now I taste them with delight, and I rejoice in the hope of a sweeter and more complete taste of them on high. ${ }^{146}$

In his work on the love of God Watts argues that this work of regeneration also has the effect of reorienting passions towards God:

It is the Spirit of God who raises dead sinners at first into a divine life, and he puts all the languid springs of life into new motion. Those vigorous and active powers of the soul, which have so strong an influence to promote the vivacity and beauty of true religion, are under his government, and they want a divine touch from his finger, to quicken and accelerate their motions. It is he who awakens our fear, who excites our hopes, who kindles our love and desire to things holy and heavenly; and it is he who exalts our spiritual joys. $^{147}$

As we will see below this renewal of the Spirit continues as part of his ongoing sanctifying work. We see another example of this in a sermon on God's healing a wayward sinner; Watts speaks on behalf of God:

I will heal him; that is, I will renew all his inwards passions, I will renew all his affections; I have done it once already, but he has almost lost the divine tincture, but I will restore it again. ${ }^{148}$

Hence Watts is an early example of what will become common in evangelical theology in the mid-century revivals: an affective element in conversion, rather than mere

\footnotetext{
${ }^{145}$ Watts, Works, 'Humble Attempt', Volume 3, 50-51.

${ }^{146}$ Ibid., 'Sermons', Volume 1, 188.

${ }^{147}$ Ibid., 'Love of God', Volume 2, 709-10.

${ }^{148}$ Watts, Posthumous Works, Volume 2, 271.
} 
acknowledgement of propositional truth. He also speaks in similar terms to the new spiritual taste that Jonathan Edwards was famous for. ${ }^{149}$

Another aspect of conversion for Watts is in overturning the disorder sin brought to the workings of passion and reason. Watts speaks of the Spirit re-establishing harmony between the faculties. Part of the Spirit's work is to:

...reform our natures, to put all our misplaced and disjointed powers into their proper order again, and to maintain this divine harmony and peace. It is the blessed Spirit that inclines reason to submit to faith, and makes the lower faculties submit to reason, and obey the will of our maker, and then gives us the pleasure of it. ${ }^{150}$

Hence reason is re-established as the ruler of the faculties and the divinely created order is brought into being. We see this new harmony of the faculties by the work of the Spirit in Watts' hymns. For example a hymn on regeneration speaks of how we are powerless to reform ourselves, but:

The Spirit, like some heav'nly wind,

Blows on the sons of flesh,

New-models all the carnal mind,

And forms the man afresh. ${ }^{151}$

Similarly the poem mentioned above on how passion turns us against God and enslaves us to sin continues in this way:

Great God, create my soul anew, Conform my heart to thine,

Melt down my will, and let it flow, And take the mould divine. ${ }^{152}$

\footnotetext{
${ }^{149}$ See for example Michael McClymond, "Jonathan Edwards," in The Oxford Handbook of Religion and Emotion, ed. John Corrigan (Oxford: Oxford University Press, 2008), 409.

${ }^{150}$ Watts, Works, 'Sermons', Volume 1, 10.

${ }^{151}$ Ibid., 'Sermons', Volume 1, 179.

${ }^{152}$ Ibid., 'Horae Lyricae', Volume 4, 356.
} 


\subsection{The passions and Christian living}

We saw above Watts' understanding of the motivational role of the passions. This comes to the fore in his view of their place within the Christian life. The engagement of the passions will keep the Christian soul firmly attached to God in a way that reason and understanding will not. He says:

Even where reason is bright and the judgment clear, yet it will be ineffectual for any valuable purposes, if religion reach no farther than the head, and proceed not to the heart: it will have but little influence if there are none of the passions engaged. ... Cold, unaffecting notions, will have no powerful influence to reform our lives. ${ }^{153}$

This has the practical effect of making the duties of the Christian life much easier. When the affections are engaged in the love of God the Christian life is seen to flow naturally, and with power:

What the nerves and spirits are to animal nature, the same thing are the passions to the soul: They are it's very nerves and spirits, it's most vigorous and unwearied springs of action, both in the zealous discharge of every duty, and the firm resistance of every temptation to sin. These active springs set all nature at work in the affairs of grace. ${ }^{154}$

An example is the passion of shame: while shame can make Christians quiet about their faith Watts says Christians should bind themselves publicly to Christ so that they would be shamed to disown him. So he speaks of the advantage of having 'this strong piece of artillery taken out of the enemies hand and placed on the side of God and religion. ${ }^{155}$ Here is the motivational power of the passions employed for God.

Watts also sees God as accommodating himself to stimulate these passions so as to motivate our ongoing living for him. He cites God's revelation of himself in scripture:

\footnotetext{
${ }^{153}$ Ibid., 'Love of God', Volume 2, 663.

${ }^{154}$ Ibid., 'Love of God', Volume 2, 666.

155 Abney, "Sermon Notes," 125-26.
} 
And therefore when he wrote these holy messages to us by his apostles and prophets, he does not only reveal things to our understanding, which reason could not find out, and then leaves us to make the best of them; but he warmly and powerfully addresses himself to the affectionate principles within us, in order to make the discoveries of his grace pierce deeper into our souls... 156

Another example is God's wisdom in ordering our worship to include elements which arouse the affections such as singing, baptism and the Lord's Supper. Divine worship has components which 'are suited to work upon our senses, and thereby to awaken pious passions within us. ${ }^{, 157}$

\subsection{The passions and Christian experience}

We noted in the previous chapter Watts' view of the ordinary and extraordinary witness of the Holy Spirit. ${ }^{158}$ For Watts the ordinary witness of the Spirit brings knowledge of eternal life which can be summed up in 'happiness and holiness'. ${ }^{159}$ The element of 'happiness' involves two areas. First there is the experience of forgiveness with consequent peace of conscience and knowledge of God's favour. Watts believes there must be some experiential element to this happiness of forgiveness:

Can the thirsty soul taste of the running water and not find refreshment, since God, who created the water, has ordained it to refresh the thirsty... No more can a guilty, distressed and penitent sinner believe the truths of the gospel, and trust in Jesus the saviour, and yet find no relief... ${ }^{160}$

This affect of the gospel on the passions is often seen in Watts' hymns. For example a hymn which examines God's favour and love towards his people invites the Christian to appropriate response:

Now shall my inward joys rise,

\footnotetext{
${ }^{156}$ Watts, Works, 'Love of God', Volume 2, 676.

${ }^{157}$ Ibid., 'Love of God', Volume 2, 679.

${ }^{158}$ Chapter 2, sections 6.2 and 6.3.

${ }^{159}$ Watts, Works, 'Sermons', Volume 1, 6.

${ }^{160}$ Ibid., 'Sermons', Volume 1, 197.
} 
And burst into a song;

Almighty love inspires my heart

And pleasure tunes my tongue. ${ }^{161}$

Another hymn speaks about our relationship with Christ where, though he is absent, he is known to us through his word and grace:
And when we taste thy love,
Our joys divinely grow
Unspeakable, like those above,
And heav'n begins below. ${ }^{162}$

This experience of forgiveness is also felt by the believer when he is recovered from backsliding. In a sermon on God's healing of the backslider Watts lists the ways in which the person may become aware of God's forgiving grace and in each case there is an affect on the passions. For example, in hearing God's voice of pardon: 'all the soul melts while its beloved speaks, and there is a great turn wrought upon the spirit. ${ }^{, 163}$

The second area of happiness in the Christian life involves the pleasant experience of living out the reordered faculties:

The happiness of eternal life consists in the pleasure that arises from the regular operation of all our powers and passions. This was a great part of the happiness of the innocent man... ${ }^{164}$

If the Christian sins there is an experience of disruption of this new order and the pleasure is lost. The soul of the Christian will then unsettled until the harmony and pleasure is re-established through repentance. ${ }^{165}$

\footnotetext{
${ }^{161}$ Ibid., 'Hymns', Volume 4, 161.

162 Ibid., 'Hymns', Volume 4, 183.

${ }^{163}$ Watts, Posthumous Works, Volume 2, 275.

${ }^{164}$ Watts, Works, 'Sermons', Volume 1, 9.

${ }^{165}$ Ibid., 'Sermons', Volume 1, 10. Also see a hymn called 'Backsliding and Returns', ibid., 'Hymns', Volume 4, 205-06.
} 
In describing the 'pleasure' that comes through living out the Christian life in its correct ordering Watts shows a similarity to the sentimentalists such as Hutcheson. However this takes on a different meaning within Watts' wider theological framework. The similarity is in the pleasure of living as God intended with the whole person in harmony; the difference comes in the supernatural work required for this to be brought about. This again reflects a different view of the effect of sin.

We have covered the ways in which the ordinary witness of the Spirit affects the passions. For Watts though it is the extraordinary witness of the Spirit where the passions come into play in a more overt way. This is when:

...in a more immediate and more sensible manner he raises in the hearts of some of his favourites a powerful and pleasant sense of their interest in the love of God. ${ }^{166}$

A believer is overwhelmed with awareness of God's love for them and so is filled with exceeding joy. This is a passive experience that comes through God's work by the Spirit. However, says Watts, normal means may be involved such as prayer, meditation, or public worship. One conclusion he draws is that Christians should persevere in these normal means.

Watts describes similar ecstatic experiences in a section on 'The first fruits of the Spirit, or the foretaste of heaven. ${ }^{167}$ His belief is that these first fruits are experiences akin to those enjoyed by the saints in heaven because of their clear view of God in his perfection and his grace to them in Christ. Speaking of these he says: 'Now when the souls of the saints here on earth are raised to such divine contemplations, what transporting satisfaction and delight must arise., 168

As we will see below Watts is cautious as to what should be inferred from such experiences, thinks that they can be abused, and does not think every Christian will

\footnotetext{
${ }^{166}$ Ibid., 'Evangelical Discourses', Volume 2, 94.

${ }^{167}$ Ibid., 'The World to Come', Volume 1, 674-88.

${ }^{168}$ Ibid., 'The World to Come', Volume 1, 685.
} 
experience them. However he still remains positive about them and encourages the Christian to appropriately seek them.

Some examples of this type of experience are found in Watts' hymns, especially in a series based on the Songs of Solomon. For example one speaks of meeting Christ and bringing him to the church:

Sometimes I find him in my way, Directed by a heav'nly ray;

I leap for joy to see his face,

And hold him fast in mine embrace.

I bring him to my mother's home, Nor does my Lord refuse to come

To Sion's sacred chambers, where My soul first drew the vital air.

He gives me there his bleeding heart, Pierced for my sake with deadly smart; I give my soul to him, and there Our loves their mutual tokens share. ${ }^{169}$

We should note that later in life Watts was less sure as to the appropriateness of this kind of romantic language. ${ }^{170}$ In the preface to Elizabeth Rowe's work, Devout Exercises of the Heart, Watts justifies and defends her exalted language, and yet says that although he used the Song of Solomon in his own hymns he no longer thinks this is 'the happiest Language in which Christians should generally discover their warm Sentiments of Religion. ${ }^{, 171}$

\footnotetext{
${ }^{169}$ Ibid., 'Hymns', Volume 4, 171.

${ }^{170}$ In his poems on the same topic he explains that it was the fashion of earlier ages to speak in the language of the Song of Solomon and that this will 'afford some apology for the writer, in his youngest years', ibid., 'Horae Lyricae', Volume 4, 370.

${ }^{171}$ Isaac Watts, "Preface," in Devout Exercises of the Heart in Meditation and Soliloquy, Prayer and Praise, by Elizabeth Singer Rowe (London: R. Hett, 1738), v.
} 
He goes on however to recommend readers use Rowe's meditations in the hope that they will be the means of a similar experience of God for them:

Whatever Ardours of divine Love have been kindled in a Soul united to Flesh and Blood, may also be kindled by the same Influences of Grace in other Spirits. ${ }^{172}$

A caution is introduced however in not making such experiences normative, nor a standard to judge their own piety:

Ten thousand Saints are arriv'd safe at Paradise, who have not been favour'd, like St Paul, with a Rapture in the third Heaven, nor could ever arise to the affectionate Transports, and devout Joys of Mrs Rowe. ${ }^{173}$

We've seen the particular affect on the passions related to the witness of the Spirit. Watts also speaks in a more general way about the passions in Christian experience. For example he says that our love for God has an experiential dimension to it whereby our passions are raised towards God. Watts says it involves 'an out-going of the heart after him, with most intense longings, and most pleasing sensations. ${ }^{174}$

This is part of a wider point: Watts thought that all truth should have a concomitant affect on the heart. For example he chided Locke in one of his poems for the 'wav'ring and cold assent' he gave to divine truths. ${ }^{175}$ Cold assent was anathema to Watts. This was one of his greatest concerns with the church of his day. He laments:

Our hearts are cold as well as dark: How seldom do we see that fervency of spirit in religious duties which God requires? How cool is our love to the greatest and best of beings? How languid and indifferent are our affections to the Son of God, the chiefest of ten thousand and altogether lovely? And

\footnotetext{
${ }^{172}$ Ibid., XXV.

${ }^{173}$ Ibid., XXV.

${ }^{174}$ Watts, Works, 'Love of God', Volume 2, 642.

${ }^{175}$ Ibid., 'Horae Lyricae', Volume 4, 397.
} 
how much doth the devotion of our souls want it's proper ardour and vivacity. $^{176}$

\subsection{The reassurance of the passions}

While for Watts the passions are expressly not designed to ascertain truth they still bring reassurance to the believer. We have seen this in the previous chapter where we looked at Watts' view of the reasonableness of Christian experience and its epistemological value. ${ }^{177}$ As mentioned above Watts argued for both the ordinary and extraordinary witness of the Spirit by which Christians became aware of his work in their life. These marks include far more than changed passions, but the passions are included and awareness of them then reassures the Christian of the divine work that had taken place in their heart. ${ }^{178}$

Watts counsels caution in the reassurance that one might gain from the extraordinary witness of the Spirit. He says, 'value the evident marks and characters of the children of God, wrought in your hearts, more than the ecstasies of joy and pleasure. ${ }^{179}$ He goes on to say that people's dependence on rapturous experiences for their assurance is the reason for their doubts and fears. Hence while Watts is positive about such experiences of God with their heightened affect on the passions, he gives them a relatively low epistemic value, much lower than that of the ordinary witness of the Spirit.

As we saw in the previous chapter however the ordinary witness of the Spirit is seen to have great value in assurance, ultimately more than rational arguments. This witness is a tasting of the goodness of God in the gospel that is, by definition, an individual experience. Watts says, 'it is like the hidden manna, which none knows but they that taste of it.' However it then shows itself in life. He gives the example of Jonathan: 'he tasted of the honey, and his eyes were enlightened. ${ }^{180}$ This metaphor of 'tasting' is also used in some of Watts' hymns, especially in drawing near to God. For example:

\footnotetext{
${ }^{176}$ Ibid., 'The World to Come', Volume 1, 626.

${ }^{177}$ Chapter 2, section 6.

${ }^{178}$ Watts, Works, 'Evangelical Discourses', Volume 2, 89.

${ }^{179}$ Ibid., 'Evangelical Discourses', Volume 2, 103.

${ }^{180}$ Ibid., 'Sermons', Volume 1, 22.
} 
Go then, my soul, address the Son,

To lead thee near the Father's face;

Gaze on his glories yet unknown,

And taste the blessings of his grace. ${ }^{181}$

A different example comes from a work on the Trinity. Watts adds what he calls a 'moral argument' to the biblical and systematic arguments he has been amassing. The moral argument runs as follows: throughout history Christians have worshipped the Son and Spirit as divine and they have done so in a variety of circumstances, including that of being 'under the most sensible impressions of love of the Father, and the Son, and under the most quickening influences of the blessed Spirit himself.' God would not have given such experience of himself if they had been wrong about the identity of the Son and Spirit because he would not bless idolatry. ${ }^{182}$ Hence doctrinal accuracy is supported by experiential piety.

There is a degree of tension between this and one of Watts' examples of abuse of the passions below where he says people should not infer from their experience that their method of worship is correct. It would seem that Watts is saying that a particular experience as described above is reassuring and affirming of a truth, but that particular experiences are never to be the basis for any doctrinal or moral position.

\subsection{The abuse of the passions}

Watts sees the primary abuse of the passions to be when their right place with respect to reason is overturned. This happens when they are used to determine truth and error or when their estimate is followed instead of that of reason. This results in 'hasty and irregular judgements, built on the passions'; and in our estimate rising 'higher toward any particular object than the judgment directs. ${ }^{183}$

\footnotetext{
${ }^{181}$ Ibid., 'Sermons', Volume 1, 130.

${ }^{182}$ Ibid., 'Christian Doctrine of the Trinity', Volume 6, 454.

${ }^{183}$ Ibid., 'Love of God', Volume 2, 684-85.
} 
This links with Watts' insistence that reasoning must be dispassionate which we noted in the previous chapter. In The Improvement of the Mind he repeatedly warns against inappropriate involvement of the passions. For example in discussing debates he says: 'Yet great care must be taken lest your debates break in upon your passions, and awaken them to take part in the controversy.' If they do, he goes on, 'Then noise and clamour and folly appear in all their shapes, and chase reason and truth out of sight. ${ }^{, 184}$ Similarly Watts argues that one disadvantage of the scholastic style of debating is that, "it carries away the mind from that calm and sedate temper which is so necessary to contemplate truth.' 185

Watts details a variety of other abuses as well as passion usurping reason. For example passions are abused:

...when they express themselves in an improper or indecent manner, and especially in such a way as is unnatural and uninstituted, foolish and ridiculous, savage and barbarous, contrary to the dictates or reason and human nature, or the word of God. ${ }^{186}$

Passions are also abused when they are present but have no effect on life and godliness:

What a reproach it is to the profession of the gospel to see a Christian just come from church and holy ordinances where his devout affections have been raised, and immediately to find him breaking out in vain, earthly merriment and carried away with idle and sensual discourse. ${ }^{187}$

The worst version of this is when the passions in question are in fact spurious. So in a hymn comparing 'A living and a dead faith', the opening verse runs:

Mistaken Souls, that dream of heav'n, And make their empty boast

\footnotetext{
${ }^{184}$ Ibid., 'Improvement of the Mind', Volume 5, 244-45.

${ }^{185}$ Ibid., 'Improvement of the Mind', Volume 5, 252.

${ }^{186}$ Ibid., 'Love of God', Volume 2, 687. Watts gives examples of icons, asceticism, and 'unbecoming sounds and gestures.'

${ }^{187}$ Ibid., 'Love of God', Volume 2, 689.
} 
Of inward joys, and sins forgiv'n,

While they are slaves to lust! ${ }^{188}$

A last example of abuse is when Christians are guided by their passions rather than by reason and as a result live by 'sudden fits and starts of devotion without that uniform and steady spring of faith and holiness. ${ }^{, 189}$ Watts speaks of those who have a particular experience such as 'a strong and divine impression from some particular scripture, or from some bright sentence in a sermon.' He does not denigrate this or seek to question its authenticity as long as it is accompanied by other signs of faith. His concern is that the person does not make such an experience a foundation for their faith. For example in a discourse on how faith is built on knowledge he says of someone: 'They have made this inward sensation the ground of their hope; they have fed still upon this cordial, and lived upon this support.' He goes on: 'when these extraordinary supplies fail them, they sink, and tremble, and die. ${ }^{190}$

Similarly in a sermon on the blessedness of faith without sight he speaks of those who 'derive almost all their evidences of the love of God from their holy Raptures, from supposed visions ... or from lively and religious dreams.' Such people he says 'cannot give any clear account of the reasons of their hope., ${ }^{191}$

What Watts desires to see is a faith that comes from right understanding of scripture and so has solidity to it, whatever the current experiential state of the believer; but that this is then added to by experiential knowledge. In this ideal situation: 'your faith and hope being built upon a regular knowledge, you may have a blessed treasure of Christian experiences to establish and exalt it. ${ }^{, 192}$ For Watts then exalted experience of God is the icing on the cake rather than the cake itself, and his concern is when believers mistake the two. But we might also say he does usually expect cakes to have icing.

\footnotetext{
${ }^{188}$ Ibid., 'Hymns', Volume 4, 192.

${ }^{189}$ Ibid., 'Love of God', Volume 2, 692.

${ }^{190}$ Ibid., 'Evangelical Discourses', Volume 2, 77.

${ }^{191}$ Watts, "Wattiana," 'The Blessedness of Faith Without Sight', 198.

${ }^{192}$ Watts, Works, 'Evangelical Discourses', Volume 2, 78.
} 
The possibilities of abuse are not taken by Watts as to mean there is anything wrong in the passions themselves, only that they can be used wrongly. The conclusion is that there is a great need for the Christian to examine themselves:

To guard against these dangers let Christian frequently enter into their own hearts and endeavour as far as possible to examine their own spirit and conscience, to distinguish between their inward workings of piety, and the mere exercises of animal nature, or the workings of corrupt affection and set a constant guard on their hearts in this respect. ${ }^{193}$

\subsection{Summary and comparison}

Watts sees conversion as returning the passions to their correct place and bringing about appropriate passions such as sorrow for sin and love for God. They then take their place as a significant dynamic of the Christian life bringing experience of God and his love, motivation in living for God, and happiness in the experience of eternal life. All of which is to be reassuring to the Christian.

In these areas Watts is overall far more positive about the role of the passions than most of his contemporaries. Other writers speak of Christian joy but it often stems only from an aesthetic source in contemplating God's beauty or magnificence. For example Butler speaks of our how God has created mankind in a way to respond to him:

He hath given us certain affections of mind, which correspond to Wisdom, Power, Goodness; i.e. which are raised upon a View of those Qualities. If then he be really wise, powerful, good; he is the natural Object of those Affections. ${ }^{194}$

Similarly Francis Bragge, an Anglican divine, speaks of God as the perfect being in whom we will be satisfied. He says God is 'the First Fair, as Plato Excellently Expresses it, the Immense Ocean of Beauty, and the Original Good. ${ }^{195}$ While Watts

\footnotetext{
${ }^{193}$ Ibid., 'Love of God', Volume 2, 691.

${ }^{194}$ Butler, Fifteen Sermons, 273.

${ }^{195}$ Francis Bragge, A Practical Treatise of the Regulation of the Passions (London: John Wyat, 1708), 44.
} 
would agree with these ideas he also speaks of the Christian's experiential knowledge of God's love and favour and does so in exalted terms.

Sentimentalists such as Shaftesbury and then Butler spoke of the ethical joy that forms part of the good life. Potkay says for Shaftesbury:

...we act virtuously because in doing so we fulfil our natural essence, and in fulfilling our essence we not only make ourselves "happy" - i.e. we flourish as human beings - but we also experience conscious joy. ${ }^{196}$

For Watts there is certainly joy to be had in living a virtuous life, however it comes as part of the larger context of being reoriented to God and having our faculties restored by his Spirit. Significantly it also looks ahead to the joy of the future which Shaftesbury wished to eliminate.

There is greater similarity to the way William Law emphasised that devotion and commitment in living for God 'fills our live with the greatest peace and happiness, that can be enjoy'd in this world.' Law's argument is that our uneasiness and unhappiness flows from our unnecessary and misguided passions, and even the temperate life does not escape misery. The answer for Law lies in reducing desires, regulating them by religion, and above all by being devoted to God. ${ }^{197}$ The great difference in Watts is that there is far more emphasis on our passions being renewed and redirected and so being seen positively. In Law the focus is that of 'the greatest denials of our passions, and the strictest rules of religion. ${ }^{198}$

In his view of the passions in the Christian life Watts anticipates Jonathan Edwards work on The Religious Affections. ${ }^{199}$ Cherry says that Edwards saw religion as 'affectionate knowledge', and so he hedged against 'anti-intellectual enthusiasm on one

\footnotetext{
${ }^{196}$ Potkay, Story of Joy, 99.

${ }^{197}$ William Law, A Serious Call to a Devout and Holy Life (London: William Innys, 1729), 163-72.

${ }^{198}$ Ibid., 165.

${ }^{199}$ Rivers, Reason, Grace and Sentiment, Vol 1, 189.
} 
hand and an unfeeling rationalism on the other. ${ }^{200}$ In this regard Watts is virtually identical to Edwards. There are also similarities in the description of the spiritual tasting of God which has an affective element to it, as opposed to purely intellectual understanding of the gospel. ${ }^{201}$

There is a significant difference however because of the difference in context. In the hot house situation of revival Edwards' driving concern was not simply to defend affectionate religion but to critically examine its genuineness. As Smith says:

He showed how piety, though ultimately rooted in the individual's relation to God, could be subject to rational scrutiny in the form of tests aimed at revealing its genuine or spurious character. ${ }^{202}$

By contrast Watts regarded his situation as the spiritual doldrums, and he longed to see more affectionate religion. Hence while he gave some advice on testing and warned against an over-estimate of the affections, his main concern was to promote and vindicate the positive role of the passions.

We do on occasion see Watts issuing warnings where he is concerned that people are giving too high a place to their experience of God. He writes to a lady concerning inward impulses that she believed came from God. He advises:

...our Religion, faith and hope should not be built upon strong impulses and imaginations but upon a plain explication of the Gospel and a Comparison of our hearts and the frame and temper of our wills with the word of God. ${ }^{203}$

\footnotetext{
${ }^{200}$ Conrad Cherry, The Theology of Jonathan Edwards: A Reappraisal (Gardan City, N.Y.: Doubleday, 1966), 21.

${ }^{201}$ John E. Smith, "Introduction," in Religious Affections by Jonathan Edwards (New Haven: Yale University Press, 1959), 47-48.

202 Ibid., 44.

${ }^{203}$ Watts, "Letter to a lady about inward impulses."
} 
Hence where needed Watts sounded strong notes of caution. However his great concern was to vindicate and encourage the passions within the life of the Christian because he saw them as so essential to vital religion.

\section{Government of the passions}

\subsection{The use of reason and truth}

We mentioned above that Watts did not think the passions were under the direct control of the will. However he does believe that the passions can be governed and that the primary route is through reason. Having disclaimed control by the will he says:

But it may be done by the consideration of truth: For as the passions are raised by perceptions of the mind, so we may by degrees raise or suppress the passions, by applying our minds to the perception of those objects, or those truths, which are suited to these purposes. ${ }^{204}$

For Watts the passions are derivative from what we love and hate; hence he sees a foundational role in consideration of truth in these general areas such that we love and hate what we should and do so in right degrees:

Now the way to secure us from irregular exercises of love or hatred, and all the infinite train of affections that depend on them, is to form a right judgment of good and evil. ${ }^{205}$

Watts goes on to describe in detail how one should go about the government of a variety of sinful passions such as pride, scorn, malice, envy, etc. In each case he explores the wrong understanding that lies behind such passions and describes the truth that should be considered and taken to heart to subdue the passion in question.

So for example in discussing pride he includes mankind's origin and destiny; God as the giver of all things; the majesty of glory of God; the humility of Christ; the emptiness of

\footnotetext{
${ }^{204}$ Watts, Works, 'Doctrine of the Passions', Volume 2, 609.

${ }^{205}$ Ibid., 'Doctrine of the Passions', Volume 2, 610.
} 
the things we take pride in; our sins and failings; the unpleasant results of pride; God's hatred of pride; and, the eventual punishment of the proud.

While this is all an example of 'consideration of truth' to govern the passions, Watts does not mean bare cognitive recognition. He has in mind understanding and absorption of these truths such that the appropriate passions are elicited. This is seen in the language he uses: the truths he speaks about are presented in heartfelt rhetoric so as to persuade the reader and draw out a response involving the emotions. ${ }^{206}$

Watts also gives a variety of general directions in aiding the governance of the passions such as noting those we are most liable to, and bewaring covering wrong passions with fine sounding names. In doing so he shows both a keen sense of practical application and awareness of the foibles of human nature. ${ }^{207}$ However he also says that while reason and resolution will do much, religion brings divine strength to our government. This leads us to our next section.

\subsection{The pre-eminence of the love of God}

We have seen that, for Watts, passions flow from what we love and hate. The overriding theme of his discourse Of the Love of God is that a true love for God is the supreme means of the government of the passions. For Watts the love of God:

...in a sovereign manner rules and manages, awakens or suppresses all the other passions of the soul. The whole train of affections, both the painful and the pleasant ones, are under the power and regulation of love. ${ }^{208}$

So Watts says that the love of God is a 'sovereign bridle, that could reach and manage them all; one golden reign, that would hold in all their unruly motions, and would also excite and guide them at pleasure. ${ }^{209}$

\footnotetext{
${ }^{206}$ For another example see ibid., 'Humility', Volume 2, 325.

${ }^{207}$ Ibid., 'Doctrine of the Passions', Volume 2, 627-30.

${ }^{208}$ Ibid., 'Love of God', Volume 2, 638.

${ }^{209}$ Ibid., 'Love of God', Volume 2, 658.
} 
Watts later elucidates all the affections which will flow from love for God including: admiration and wonder at God's works and ways; desire for God's favour; joy in God's presence; love of God's word, his people, and his Son; deadness to the world; zeal and activity for God; hatred of what offends God; fear of anything that would cut us off from God; the subduing of sinful passions; and, joyful desire of heaven. ${ }^{210}$ This list also gives us insight into Watts' understanding of passionate religion.

Watts wrote about the governing of reign of love in his poetry as well. For example:

My passions hold a pleasing reign,

While love inspires my breast,

Love, the divinest of the train, The sov'reign of the rest. ${ }^{211}$

As we would expect from what we have seen so far, for Watts the love of God goes hand-in-hand with right knowledge of God. This knowledge involves both right understanding but also personal awareness of God's mercy towards us and a delight in God himself.

This love also means that the Christian finds all of their joys in God, in his presence and his goodness. This is shown in one of Watts' hymns addressed in the first line to 'My God, my life, my love'. A later verse says:

Thou art the sea of love

Where all my pleasures roll,

The circle where my passions move,

And centre of my soul. ${ }^{212}$

This love will then show itself in life and without such evidence the reality of the love is drawn into question. So Watts says:

\footnotetext{
${ }^{210}$ Ibid., 'Love of God', Volume 2, 648.

${ }^{211}$ Ibid., 'Horae Lyricae', Volume 4, 377.

212 Ibid., 'Hymns', Volume 4, 231-32.
} 
Where the love of God reigns in the affections...the eye will often look up to God in a way of faith and humble dependence; the ear will be attentive to his holy word; the hand will be lifted up to heaven in daily requests; the knee will be bended in humble worship; all the outward powers will be busy in doing the will of God and promoting his glory. ${ }^{213}$

In this Watts guards against a purely emotional religion that does not involve transformation of life. This view is well summarised in one of Watts' hymns. It speaks of love as pre-eminent, the weakness of knowledge without love, and the influence of love on life:

Happy the heart where graces reign, Where love inspires the breast:

Love is the brightest of the train, And strengthens all the rest.

Knowledge, alas! 'tis all in vain, And all in vain our fear;

Our stubborn sins will fight and reign,

If love be absent there.

'Tis love that makes our cheerful feet

In swift obedience move;

The devils know and tremble too,

But Satan cannot love. ${ }^{214}$

\subsection{The excitement of the passions}

Watts' position leads him to the logical conclusion that the devout Christian should want to arouse passionate love for God. Hence he proposes 'a few proper methods, whereby the affections of nature may be awakened and employed in the christian life.' Indeed there is a great need for Christians to give themselves to this duty:

Take all opportunities to warm your heart with this sacred passion, and to re-kindle the fire of divine love within you, when at any times you feel it declining. $^{215}$

\footnotetext{
${ }^{213}$ Ibid., 'Love of God', Volume 2, 643.

${ }^{214}$ Ibid., 'Hymns', Volume 4, 212.
} 
The methods Watts suggests flow from his understanding of human psychology as well from a variety of pragmatic observations. As he sees our understanding as being the basis for our affections he believes deep passion for God requires deep and clear knowledge of God. Hence he encourages depth of learning and understanding, including the necessity to have clear ideas in our minds for our concepts of God. ${ }^{216}$

Emotional expression is encouraged in private spiritual practices such as prayer and reading. Here Watts says the passions can and should be given a freer reign than would be appropriate in a public setting. Such private activity 'will keep all the passions in a habitual practice of religion, and maintain inward piety in the life and power of it. ${ }^{217}$

Watts also sees responsibility for the excitement of passions as falling to the Christian community at large. He wants to sees members of a church speaking to each other so as to deliberately arouse the love of God in each other's hearts:

Mutual conversation shall raise the divine flame higher, like united torches, which increase each other's blaze... Man is a social creature, and his passions were made to be raised by converse. ${ }^{218}$

Watts sees a prime place for meditation specifically aimed at exciting love for God. A variety of techniques are outlined such as consideration of an attribute of God and reflection on the appropriate emotional response. The psalms are seen as especially useful in this regard as Watts considers them the most affecting part of scripture - 'an altar of sacred fire.' Watts advises that his readers:

...lift up your souls to God in the words of David, or imitate his language, where his words do not so perfectly express your case. Enter into his spirit, form and model your pious affections by that illustrious pattern; and be sure

\footnotetext{
${ }^{215}$ Ibid., 'Love of God', Volume 2, 704-05.

${ }^{216}$ See Chapter 2 section 2.3.

${ }^{217}$ Watts, Works, 'Love of God', Volume 2, 706.

${ }^{218}$ Ibid., 'Love of God', Volume 2, 709.
} 
to bring Christ and the sweet discoveries of grace, and the blessings of the gospel into this sort of devotion. ${ }^{219}$

Also encouraged is meditation on the future. He advises:

Set yourself continually on the border of the grave, and the invisible world... Then this world will be as a dead thing in your eyes; it will have very little power to work on your passions and to draw you aside from God. He will be your love and your all. ${ }^{220}$

Reflection on the future appears in other works as well. In his work A Caveat Against Infidelity as part of Watts' 'preservatives against apostasy' he recommends:

Come, let us dwell a little on the glorious discoveries of the heavenly world, which the gospel has made, till our desires are warmed, and our zeal kindled to pursue and enjoy these sacred and sublime felicities. ${ }^{221}$

This dynamic of joy aroused by contemplation of the future is seen in Watts' hymns as well. For example in a hymn on 'Heavenly joy on earth', he writes:

Yes, and before we rise

To that immortal state,

The thoughts of such amazing bliss

Should constant joys create. ${ }^{222}$

But even greater than consideration of heaven is the effect Watts believes meditation on the cross of Christ should have on the passions. In considering the advantages of God having saved us through the atonement Watts says of considering the cross:

\footnotetext{
${ }^{219}$ Ibid., 'Love of God', Volume 2, 708.

${ }^{220}$ Ibid., 'Love of God', Volume 2, 710. While Richard Baxter is not mentioned there is similarity with Baxter's encouragement of meditation on the future in The Saints Everlasting Rest.

${ }^{221}$ Ibid., 'Caveat against Infidelity', Volume 2, 528.

${ }^{222}$ Ibid., 'Hymns', Volume 4, 209.
} 
By this means our religious fear of God will be greatly increased, and our love to him be inflamed to a much higher degree, as indeed the benefit of our forgiveness, when it is set in this light, requires. ${ }^{223}$

This is also seen in many of Watts' hymns which lead the worshipper to meditate on the cross. The most famous is When I Survey the Wondrous Cross. The hymn has a strong visual element where the believer 'surveys' the cross, and this contemplation has a transformative effect, including an effect on the passions. ${ }^{224}$

Another hymn examining the cross of Christ in detail begins with this stanza:
Alas and did my Saviour bleed?
And did my Sov'reign die?
Would he devote that sacred head
For such a worm as I?

It goes on to speak of Christ suffering the wrath of God and so taking the punishment for the believer's crimes. The response of the believer then includes significant effect on the passions:

Thus might I hide my blushing face,

While his dear cross appears;

Dissolve my heart in thankfulness,

And melt my eyes to tears.

However Watts knows that an emotional response is not sufficient by itself and so the hymn concludes:

But drops of grief can ne'er repay

The debt of love I owe;

Here, Lord, I give myself away;

\footnotetext{
${ }^{223}$ Ibid., 'Redeemer and Sanctifier', Volume 3, 784.

${ }^{224}$ Gordon Mursell, English Spirituality: From 1700 to the Present Day (London: SPCK, 2001), 63-67.
}

For a particular discussion of this hymn see Andrew Meszaros, "Isaac Watts: A Universal Hymn Writer," Bulletin of the Hymn Society of Great Britain \& Ireland 18, no. 11 (2008). Also see J. R. Watson, The English Hymn: A Critical and Historical Study (Oxford: Clarendon Press, 1997), 160-70. 
'Tis all that I can do. ${ }^{225}$

Hence we see contemplation of truth, arousing of appropriate passions, and commitment to live for God. Similar themes are seen in Watts' poems. For example Desiring to Love Christ moves from the cold and hardened mind of the believer to a melted heart. The means for this change is meditation on the mercy of God in Christ's incarnation and atonement. $^{226}$

This call to appropriately excite the passions towards God does not preclude the work of the Spirit, rather it is expressly dependent on it. We saw above that conversion involves the Spirit's work on the passions, and the reordering of the faculties of human nature. For Watts this work is ongoing and is essential for the right use and government of the passions:

It is only the sanctifying influence of the blessed Spirit, that can excite them in a due degree, and can give them proper limits and regulations. It is nothing but divine grace can raise them to a due height, on all just occasions, and yet preserve them from any irregular conduct and unhappy effects. $^{227}$

Hence Watts refers repeatedly to 'sanctified passions': those that are cleansed by the Spirit. The result for the Christian is that, as well as seeking to excite the passions themselves, they must also, 'Seek earnestly the influences of the quickening Spirit. Without him you can do nothing., 228

\subsection{Summary and comparison}

Watts sees our passions as being governed by right consideration of the truth; a right view of objects will bring about appropriate passions. Above all else there should be a right view of God leading to the pre-eminent love of him above all else. If this is in

\footnotetext{
${ }^{225}$ Watts, Works, 'Hymns', Volume 4, 202.

${ }^{226}$ Ibid., 'Horae Lyricae', Volume 4, 370. This poem is part of a series dedicated to 'Divine Love' which regularly includes similar themes.

${ }^{227}$ Ibid., 'Love of God', Volume 2, 693-94.

${ }^{228}$ Ibid., 'Love of God', Volume 2, 709.
} 
place all the other passions will take their correct place. Hence despite some similarities Watts lands in a different position to moralists like Hutcheson who believed our longterm rational affections should control our passions. ${ }^{229}$

While standing apart from the moralists Watts' view places him in the mainstream of much Christian teaching on the topic. For example Bragge speaks of regulation of the passions by correct estimation of objects: we must, 'Fix and Settle in our Minds such Apprehensions of the Good and Evil of Things, as will Excite us vigorously to Pursue the Good and Avoid the Evil. ${ }^{230}$

There is however a tendency in most writing to speak of government of the passions such that will produce a clam and moderate life. Bragge again says:

When our Passions are thus brought into the Right Course and Chanel, they'll flow Silently and Smoothly on, and serve like Oars and Sails to bring us to the Enjoyment of our Supreme Good; which we shall then Pursue with Vigour, but without Perturbation, with a Swift but Even Motion... ${ }^{231}$

A similar theme is seen in a sermon by the Presbyterian minister Robert Fleming. ${ }^{232}$ Fleming argues that excessive love for a family member is sinful, unreasonable, and hurtful to the soul. Instead he calls for a 'right Regulation of our Affections.' The overall tone of his sermon is of appropriate, that is to say, moderated affections.

Watts then speaks more readily of fervency of passion than many of his contemporaries. But it is in his belief that Christians must work at the appropriate excitation of the passions that Watts stands out from the majority of writing on topic in his day. Brinton says that the common applications of sermons on the passions were primarily cognitive

\footnotetext{
${ }^{229}$ Ward, "Introduction," ix-X.

${ }^{230}$ Bragge, Passions, 16-17.

231 Ibid., 20.

${ }^{232}$ Robert Fleming, A Persuasive to Moderate all Affections to Worldly Objects (London: Andrew Bell, 1716).
} 
and influenced by Seneca. ${ }^{233}$ Watts goes far beyond this in his desire that people stimulate passionate love of God.

For example Samuel Clarke speaks of moderation of the passions by way of watchfulness such that passions do not get out of control: 'Consideration, Attention and frequent Examination of a man's self; so as to keep a constant Guard and Watchfulness over his Spirit. ${ }^{234}$ But there is no discussion of a desire to stimulate appropriate passions.

The Anglican divine and poet Edward Young ${ }^{235}$ preached on the command to 'set your hearts on things above. ${ }^{236}$ He mentions having a 'relish' and 'desire' for heavenly things, but his focus is on persuading his readers of the futility of misplaced affections and to convince that only heavenly desires will bring true satisfaction. His method has a strong intellectualist element to it. In our hearts being set on earthly things he says: 'The Foundation of Error in this Point, is, all our Pains, and Pleasures, are from Sense, or Imagination, and not from Reason. ${ }^{237}$

Bragge does speak of warming our hearts towards God but wishes to down play any experience of passion in our prayer and worship. He says:

Now whether these Expressions of our Love of God, be with or without the Heat of Sensitive Passion, is all one in His Esteem, provided they are but Hearty and Sincere. For this Sensitive Fervour of Affection is but Accidental and Depends very much on the Temper of the Body, and is often found where there is no True Love of God. ${ }^{238}$

\footnotetext{
${ }^{233}$ Brinton, "Passions," 61.

${ }^{234}$ Clarke, Government of Passion, 29.

${ }^{235}$ Edward Young (1683-1765).

${ }^{236}$ Colossians 3:1-2

${ }^{237}$ Edward Young, A Vindication of Providence: Or, A True Estimate of Human Life. In which the Passions are Consider'd in a New Light (London: T. Worrall, 1728), 49.

${ }^{238}$ Bragge, Passions, 61.
} 
While Watts would agree that an experience of 'sensitive passion' does not prove anything, he would still encourage 'heat' and 'fervour' in the believer.

Others spoke of the significance of the love of God. For example Bishop Butler gave two of his fifteen sermons to it and argued that God's nature meant he was eminently worthy of our affections. The picture he paints though is much more that of admiration of God as the most perfect of beings. ${ }^{239}$ He speaks of our affections 'being raised to the highest pitch' in contemplation of God. ${ }^{240}$ However this high affection is described as a logical consequence rather than a passionate feeling, and as Butler's sermon goes on the love of God as affection for him is overtaken by the notion of 'resignation to the divine will' which is seen as the great duty of man to God. ${ }^{241}$ Hence despite discussion of love and affection it is of very different temper to Watts.

We do see a similar focus on the excitation of the passions in Jonathan Edwards. Edwards argued: 'If it be so, that true religion lies much in the affections, hence we may infer, that such means are to be desired, as have much of a tendency to move the affections. $^{242}$

Edwards here draws the connection between passion and religious practice which stimulates godly passion. We will go on to see the same in Watts where his view of the excitation of the passions has significant results in his view of preaching, praise and prayer.

In his emphasis on the work of the Spirit Watts also stands apart from the majority of discourses on the topic. John Tottie shows some similarity in saying that the Spirit can 'strengthen our reason, can purify the corrupt part of our natures, refine and exalt our passions, and spiritualise our affections.' However even here the Spirit's work is spoken

\footnotetext{
${ }^{239}$ Butler, Fifteen Sermons, 262.

${ }^{240}$ Ibid., 273.

${ }^{241}$ Ibid., 280.

${ }^{242}$ Jonathan Edwards, Religious Affections, ed. John E. Smith (New Haven: Yale University Press, 1959), 121.
} 
of extra help when 'our unruly Passions and appetites should prove too obstinate', and one of the ways in which he works is by 'co-operating with our better part. ${ }^{243}$ Hence there is far less call for utter dependence on the Spirit which goes hand in hand with a more positive view of our own abilities. Watts by contrast has a stronger doctrine of sin and hence encourages greater dependence on God.

Where Watts stands out further is in his method of discourse. We shall return to this in later chapters but it is significant to point out here. Brinton comments on the lack of 'pathetic vigour' in sermons on the passions; by comparison Watts is full of such vigour. $^{244}$ The prime example of this in his work Discourses of the love of God where he concludes each section with a 'meditation'. These meditations review and summarise the content of the chapter but do so in the first person singular, and so provide words for the reader to use. For example:

Let my devout passions be ever awake and lively when I hear the things of God spoken, or when I read of the momentous concerns of religion, and a life to come. Then the sacred truths and duties of christianity shall be impressed deep on my memory, and written there as with a pen of diamond, never to be blotted out. O may the warm passions melt my soul to tenderness, and make me susceptive of every holy impression! May this heart of mine, this table of stone, be softened by devout affection... ${ }^{245}$

In such heartfelt rhetoric Watts is sounding a note less commonly heard in the cooler discourses of his day.

\section{Summary and conclusion}

Watts' concern for the place of the passions stemmed from his view of the state of the church. In introducing his work Of the Love of God he says his reason for writing is because of the "the growing deadness and degeneracy of our age in vital religion,

\footnotetext{
243 Tottie, Reason and Passion, 25-26.

${ }^{244}$ Watts' alertness to affective language can be seen in his notes on a variety of books, see Stephenson, "Dissenting Ministry," 269-70.

${ }^{245}$ Watts, Works, 'Love of God', Volume 2, 672.
} 
though it grew bright in rational and polite learning.' He explains there are those who have made religion only about right doctrine and duty and he responds:

...where the religious use of the passions is renounced and abandoned, we do not find this cold and dry reasoning sufficient to raise virtue and piety to any great and honourable degree, even in their men of sense, without the assistance of pious affections. ${ }^{246}$

Watts repeatedly states his concern about the danger of hypocrisy which is attendant on those who dismiss the passions. Here is one example:

It is not enough for the eye to be lifted up to him, or the knee to bow before him; it is not enough for the tongue to speak of him, or the hand to act for his interest in the world; all this may be done by painted hypocrites whose religion is all disguise and vanity. But the heart with all the inward powers and passions must be devoted to him in the first place: This is religion indeed. The great God values not the service of men, if the heart not be in it. $^{247}$

As we have noted though Watts also argues that others have made religion consist too much in the emotions and have not paid due attention to reason. This leads to 'the wild temptations of fancy and enthusiasm' where the believer is unstable and prone to foolish and sinful decisions. Hence Watts guards against a variety of abuses of the passions in the name of religion.

The overall picture then is that Watts is trying to avoid the extremes of both cold reasoning and the dangers of ungoverned passion, and to maintain the 'middle way', which he believes is true to scripture and has produced 'the noblest fruits of righteousness in every age. ${ }^{248}$ However in his day this meant emphasising the necessity of passionate religion and to 'to vindicate the affectionate Christian from the unjust reproaches of men, in his warmest exercises of love to God and devotion. ${ }^{249}$ This aim

\footnotetext{
${ }^{246}$ Ibid., 'Love of God', Volume 2, 637.

${ }^{247}$ Ibid., 'Love of God', Volume 2, 640.

${ }^{248}$ Ibid., 'Love of God', Volume 2, 638.

${ }^{249}$ Ibid., 'Love of God', Volume 2, 696.
} 
means he knows he runs the risk of being labelled as an enthusiast himself. He accepts this risk and counters it by justifying the passionate experience of the believer as reasonable. We see a similar tension in his defending of other authors such as in his preface to the memoirs of Thomas Halyburton. ${ }^{250}$

We have commented as to how the religious mood of the early eighteenth century was a self-conscious reaction against what was seen as the enthusiasm of the previous era allied with the influence of scientific and rationalistic advances. So Steele says of the majority of divines:

They promoted sweet reasonableness and gentle sentimentality in place of the hotheaded zeal and cold-hearted dogmaticism of the Cavaliers and the Roundheads, but somehow failed to instill in people the joyous selfabandonment of the apostles and martyrs. ${ }^{251}$

The spectre of revolution was always looming over any hint of enthusiasm; indeed there was an ongoing move to identify enthusiasts as fanatics who threatened civil order. ${ }^{252}$ Heyd argues that this resulted in the established church adopting more secular attitudes, in particular a rationalising tendency. ${ }^{253}$ Within these cross-currents Watts wishes to keep his own distance from unreasonable and unstable enthusiasm, but also to insist on the necessity of spiritual fervour and to decry the stagnating influence of cool rational religion.

Rivers comments on a tension in Watts (and also Doddridge) as to whether 'the affections are concerned primarily with action or feeling., ${ }^{254}$ While acknowledging Watts' linking of passion to motivation hence action, she sees his primary terminology as referring to feelings experienced. This, she believes, results in an inconsistency in treatment of the passions such that experience of God is both promoted and cautioned against; Watts is seen as caught between two minds on the matter.

\footnotetext{
${ }^{250}$ Halyburton, Memoirs, viii-ix.

${ }^{251}$ Steele, "Gracious Affection", 4.

252 William T. Cavanaugh, "The Invention of Fanaticism," Modern Theology 27, no. 2 (2011): 229-31.

${ }^{253}$ Heyd, Enthusiasm, 165-90, 274-78.

${ }^{254}$ Rivers, Reason, Grace and Sentiment, Vol 1, 192.
} 
Rivers points out that part of the explanation is Watts' concern not to be misheard or misapplied by those who might be more zealous. However another factor is the different ways in which Watts refers to the passions which we have noted in our analysis. When speaking of our love for God Watts sees this as clearly having experiential elements to it, but also as always leading to action. Hence his terminology is then more frequently connected to the action of the believer. But when Watts speaks of our experience of God's love for us he speaks more of passions as feelings we experience. Unlike our love for God he believes this experience will vary among believers and so is correspondingly more cautious. This is especially so for the more exalted experiences of the special witness of the Spirit where he guards people from over reliance on such experiences.

We have previously noted the ongoing tensions between rationalism and evangelicalism described by Rivers in the dissent of the first half of the eighteenth century. The rationalistic element led to: 'hostility to feeling and the influence of the Spirit in religion, and a growing sympathy ... with the moralistic latitudinarian strain in the Established church. ${ }^{, 255}$ Watts is explicitly countering such hostility to feeling and the work of the Spirit. In addition he is working against the moralistic strain of the established church, not by undermining morality, but by setting it within the broader compass of sin, conversion and reoriented passions.

This is where it is useful to compare to Watts to other voices within his day. Intellectualists such as Samuel Clarke saw reason as the leading faculty that would direct the passions, and believed it contained motivational power within itself. ${ }^{256}$ Watts sees the contemplation of truth as key to directing the passions but he views reason as impotent to motivate, and hence grants much greater power to the passions.

Sentimentalist moral philosophers saw the passions as leading faculty of the soul which directed right action. Watts makes positive comments about the work of Butler and Hutcheson in this regard. However he views such moral sense as the remnant of our

\footnotetext{
${ }^{255}$ Ibid., 167.

${ }^{256}$ Fiering, Moral Philosophy, 196.
} 
original created form now corrupted by sin. And sin's power is such that moral sense cannot be relied on for direction or motivation. Rather our passions must be reordered by the Spirit, and then rightly sanctified.

Neo-hedonists such as Mandeville made self-interest the main motivational power that would result in public benefits. Watts agrees that self-love exists, and affirms it in the form presented by moral sentimentalists. However even in its benevolent form it is placed in a larger theological framework of sin and grace, reward and punishment, from which it derived its integrity.

Behind such comparisons lies Watts' view of human nature. He is more inclined to see people as vicious than virtuous, and selfish than social. He does acknowledge elements of natural virtue and social affections, and in this way reflects elements of the new thinking of his day. However his doctrine of sin is too strong to allow such ideas great influence. So Watts says:

One would think indeed, that man should not dare to indulge any sinful passion towards his maker; but so corrupt are our hearts, that we dislike the holy nature of God, we are displeased with his will, and his holy commandments are grievous to us, till the love of God subdue this inward aversion of the heart to holiness, and reconcile us to the law of God by the constraining influence of divine love. ${ }^{257}$

As with the role of reason it is useful to compare Watts to Puritan thought on the place of the passions. Again, comprehensive comparison is not possible, and we recognise the diversity within the Puritan camp. However a few brief soundings indicate some lines of continuity and development.

We notice first that Watts' partial agreement with the sentimentalists of his day represents a departure from Puritan thinking. Puritan theology had emphasised natural law as the moral law of God implanted on people's hearts. However this was primarily known by the conscience and reason; there was no concept of the passions providing a

\footnotetext{
${ }^{257}$ Watts, Works, 'Love of God', Volume 2, 654.
} 
moral compass. ${ }^{258}$ For examples see works by William Fenner and John Owen. ${ }^{259}$ As we have seen however Watts only has a partial agreement with the sentimentalists, links moral sentiment with rationality and retains a strong doctrine of sin. Hence his departure is only partial.

On the topic of self-love Watts' position continues an Augustinian interpretation that did not pit love of self against love of God, but rather saw love of God as in our best interest. While some Puritans defined self-love as the heart of sin, this Augustinian position is still seen in many Puritans in the seventeenth century. ${ }^{260}$ There is a tendency however for Watts to focus on the rewards God gives rather than God himself as the greatest good and reward which was the common Puritan position.

In the emphasis on heartfelt religion however there is great continuity with his Puritan background. It has been well recognised that Puritan theology had a high view of the affections and of 'heart religion' in general. ${ }^{261}$ William Fenner wrote a Treatise of the Affections (1641) in which we see similarity and difference to Watts. There is the traditional view of affections arising from the qualities of an object, and seeing God as the object eminently worthy of our highest affection. This results in practical advice for the believer as to how to fix their affections on God that are echoed in Watts. The main difference lies in the view of the faculties of the soul. Fenner has a two faculty view where by man is created with a 'reasonable soul consisting of an understanding and a will. ${ }^{262}$ The affections are then understood to be an aspect of the will:

\footnotetext{
${ }^{258}$ David VanDrunen, Natural Law and the Two Kingdoms: A Study in the Development of Reformed Social Thought (Grand Rapids, Mich.: Eerdmans, 2010), Chapter 5.

${ }^{259}$ William Fenner, The Soules Looking-Glasse Lively Representing its Estate before God, ed. Edmund Calamy (Cambridge: Roger Daniel, 1640); John Owen, Exercitations Concerning the Name, Original, Nature, Use, and Continuance of a Day of Sacred Rest (London: R.W., 1671).

${ }^{260}$ See Post, Love and Self-Denial, Chapter 1. For an example of self-love as the heart of sin see John Flavel, A Saint Indeed: or The Great Work of a Christian, Opened and Pressed; from Prov. 4. 23 (London: W.R., 1668), 7-8.

${ }^{261}$ Charles E. Hambrick-Stowe, The Practice of Piety: Puritan Devotional Disciplines in SeventeenthCentury New England (Chapel Hill [N.C.]: University of North Carolina Press, 1982), Chapter 2.

${ }^{262}$ This two-faculty view is seen in other Puritan writings, e.g. John Weemes, The Pourtraiture of the Image of God in Man (London: M. Flesher and G. Wood, 1627), 114.
} 
These acts of loving, fearing, etc, commonly called by the name of Affections... are onely the motions of the will, by which it goeth forth to the embracing of its object which is good. ${ }^{263}$

This reflects a more voluntaristic view of the affections, and a belief that the felt or sensitive aspects of affections are because of the affect the will has on the body: 'the will stirres up the inferior faculties of the Soule. ${ }^{264}$ A similar example is seen in John Preston who wrote of the relationship between the faculties: 'If the mind be right, the Will will follow; and if the Will follow, be sure the affections will follow. ${ }^{265} \mathrm{He}$ also defined the affections in a similar way to Fenner above as the "motions and turnings of the will. ${ }^{266}$

By comparison we saw that Watts varies between a two and three faculty view of the soul. ${ }^{267}$ This means he could speak in similar terms to Preston and Fenner above, but could also speak of how the passions act so as to motivate the will, rather than being moved by the will themselves. This is an example of the independent functioning of the passions and a reversal of flow of effect that Dixon describes. ${ }^{268}$

We see a similar comparison with Richard Baxter who wrote on the government of the passions in his Christian Directory (1673). Baxter's directions against sinful passions show great similarity with that of Watts: he begins with the need for a new heart renewed by the Spirit, the mind is directed as to what it should consider so as to control the passions, and he speaks of love as the 'master passion of the soul., 269

\footnotetext{
${ }^{263}$ William Fenner, A Treatise of the Affections (London: E.G., 1641), Introduction.

${ }^{264}$ Ibid., 7.

265 John Preston, The Breast-Plate of Faith and Love (London: W. J., 1630), 'Of Faith', 98.

${ }^{266}$ Ibid., 'Of Love', 6. Also see Edward Reynolds, A Treatise of the Passions and Faculties of the Soule of Man (London: R. H., 1640).

${ }^{267}$ See section 2.2 .

${ }^{268}$ Dixon, Passions to Emotions, 76-79.

${ }^{269}$ See Richard Baxter, A Christian Directory (London: Robert White, 1673), Part 1, Chapter 3, Direction XI.
} 
In giving specific direction there is even the possibility of dependence of Watts on Baxter. For example with regard to sinful anger Baxter wrote: 'Command your tongue, and hand, and countenance, if you cannot presently quiet or command your passion. ${ }^{270}$ Watts wrote: 'Command your tongue to silence, and your hands to peace, if you cannot presently command your spirit. ${ }^{, 271}$ However within Baxter there is a stronger voluntarist strain of thinking where the will controls the passions:

Nature hath set the will in the Throne of the soul: It is the sinful connivance and negligence of the will, which is the guilty cause of all the rebellion; ... if the will were resolute without any compliance, or connivance, or negligence in its proper office, no sinful passion could remain, for it is no further sin than it is voluntary, either by the wills compliance or omission and neglect. ${ }^{272}$

This leads us again to the uncertainty in Watts. As we have seen Watts can say that loving God involves a choice of him by the will, but he can also say that the passions cannot be directed by command of the will and often override it. We will observe ways in which this change from a Puritan position works out in practical areas in the chapters that follow.

We must also note the way in which Watts continued to sound distinctive Puritan themes. He emphasised the need of regeneration for a right ordering of the faculties of the soul including the affections, and the ongoing work of the Spirit in sanctifying the passions. He laid stress on the experience of the believer in coming to faith and then in assurance of salvation. Most of all he focussed on the dynamic of heartfelt religion as opposed to head knowledge. These are all emphasises found in Fenner, Baxter, and Owen, and in Puritan theology generally. ${ }^{273}$ Owen, for example, emphasises these

\footnotetext{
${ }^{270}$ Ibid., 343.

${ }^{271}$ Watts, Works, 'Doctrine of the Passions', Volume 2, 624.

${ }^{272}$ Baxter, Directory, 328. See the discussion on the prominent place of the will in Baxter and Bunyan in Rivers, Reason, Grace and Sentiment, Vol 1, Chapter 3.

${ }^{273}$ See Ted Campbell, The Religion of the Heart: A Study of European Religious Life in the Seventeenth and Eighteenth Centuries (Columbia: University of South Carolina Press, 1991), 44-53. Geoffrey F. Nuttall, The Holy Spirit in Puritan Faith and Experience (London: Basil Blackwell, 1946), especially
} 
elements in his work on spiritual mindedness, highlighting the need for renewal of the affections, the affections as the helm of the soul which directs life, and the results of the pre-eminence of the love of God. ${ }^{274}$

As we saw with reason then, Watts is tethered to his Puritan forefathers, but makes significant adjustments to his view of the passions in the light of the natural philosophy of his day. This results in a degree of ambiguity over functioning of passions, there is acknowledgement of an innate moral sense, and overall there is larger place found for the importance of the passions. But he speaks, as a Puritan, of the corruption wrought by sin, of the need for a new heart, of the goodness of sanctified passions, and of the delight of experiencing God.

Watts then aims to defend the passionate Christian and urges his readers to pursue such experiential piety. He plaintively asks:

Hath he formed my soul to delight and love and hath confined these sweet and pleasurable capacities only to be employed about creatures, when the Creator himself is supreme in loveliness? Will not this most amiable of beings expect that I should love himself, and give me leave to make him my delight? $?^{275}$

And he calls on the church to revive passionate religion:

Let us long and breathe after these sacred sensations of refined pleasure, to which the church it self is too much a stranger, in our degenerate times. ${ }^{276}$

chapter 9. Charles Lloyd Cohen, God's Caress: The Psychology of Puritan Religious Experience (Oxford: Oxford University Press, 1986), 94-103.

${ }^{274}$ John Owen, The Grace and Duty of Being Spiritually-Minded Declared and Practically Improved

(London: J.G., 1681), see especially Part 2.

${ }^{275}$ Watts, Works, 'Love of God', Volume 2, 697.

${ }^{276}$ Ibid., 'Love of God', Volume 2, 674. 


\section{Chapter 4 The Art of Preaching}

\section{Introduction}

\subsection{Background}

For the background to preaching in the first half of the eighteenth century the reader is directed to the appropriate literature. ${ }^{1}$ Our aim here is to briefly sketch those factors which are pertinent for setting Watts in his historical context. The sermons of the seventeenth century pulpit can be stereotyped into two categories: the baroque, and the Puritan. $^{2}$ The baroque is exemplified by preachers such as John Donne and Lancelot Andrews and is well known for its 'ostentatious display of learning, and the fitting of meaning to form rather than structuring form solely for the better articulation of the meaning. ${ }^{3}$

The Puritan style of preaching is difficult to summarise because of variation between preachers and over time. Key features however are seen in the enormously influential

\footnotetext{
${ }^{1}$ See Peter E. McCullough, Hugh Adlington, and Emma Rhatigan, The Oxford Handbook of the Early Modern Sermon (Oxford: Oxford University Press, 2011). O. C. Edwards, A History of Preaching (Nashville, Tenn.: Abingdon, 2004). Hughes Oliphant Old, The Reading and Preaching of the Scriptures in the Worship of the Christian Church. Volume 4, The Age of the Reformation (Grand Rapids: W.B. Eerdmans, 1998). Edwin Charles Dargan, A History of Preaching, vol. 1 (Grand Rapids: Baker Book House, 1954). F. R. Webber, A History of Preaching in Britain and America (Milwaukee: Northwestern Publishing House, 1952). Caroline Francis Richardson, English Preachers and Preaching, 1640-1670: A Secular Study (New York: Macmillan, 1928).

${ }^{2}$ Although for different categories see Mary Morrissey, "Scripture, Style and Persuasion in SeventeenthCentury English Theories of Preaching," Journal of Ecclesiastical History 53, no. 4 (2002). Davies also introduces a third category of 'Senecan' preachers, Horton Davies, Worship and Theology in England: Volume 2, from Andrewes to Baxter and Fox, 1603-1690 (Princeton: Princeton University Press, 1975), 154-61.

${ }^{3}$ David A. DeSilva, "The Pattern for Preachers: Archbishop John Tillotson and the Reform of Ecclesiastical Oratory in the Seventeenth Century," Anglican \& Episcopal History 75, no. 3 (2006): 373.
} 
manual by William Perkins, The Art of Prophesying. ${ }^{4}$ This shows the influence of Ramus' logic in the focus on functional clarity and the downgrading of rhetorical style. ${ }^{5}$ The aim was straightforward presentation of doctrines and appropriate application in plain language. ${ }^{6}$ However the worst of Puritan sermons were known for their complexity and branching nature resulting in 'interminable divisions and subdivisions." Edwards says that this gave the sermons 'the form of logical demonstrations rather than oral persuasions. ${ }^{8}$

However more positive presentations of Puritan sermons emphasising their affective quality have also been made. ${ }^{9}$ So Knott says that Puritan preachers had great concern for their listeners feeling as well as understanding what was said. ${ }^{10}$ Miller acknowledges that Puritan preaching included affectionate rhetoric alongside the deliberately presented doctrine, but says that the intensity of the piety being expressed was 'severely confined with in the framework of doctrine, reasons, and uses. ${ }^{11}$ In comparing Watts to Puritan preaching later we will need to be aware of these varied views.

\footnotetext{
${ }^{4}$ William Fraser Mitchell, English Pulpit Oratory from Andrewes to Tillotson. A Study of its Literary Aspects (London: S.P.C.K., 1932), 99. William Perkins, The Arte of Prophecying (London: Felix Kyngston, 1607).

${ }^{5}$ Peter France, "Rhetoric," in The Cambridge History of Eighteenth-Century Philosophy, ed. Knud Haakonssen (Cambridge: Cambridge University Press, 2006), 497. On Ramism in Perkins see Donald K. McKim, Ramism in William Perkins' Theology (New York: P. Lang, 1987).

${ }^{6}$ Arnold Hunt, The Art of Hearing: English Preachers and their Audiences, 1590-1640 (Cambridge: Cambridge University Press, 2010), Chapter 1.

${ }^{7}$ Mitchell, Pulpit Oratory, 258.

${ }^{8}$ Edwards, History of Preaching, 363.

${ }^{9}$ For example, J. I. Packer, Among God's Giants: Aspects of Puritan Christianity (Eastbourne: Kingsway, 1991), 365-82. Francis Bremer and Ellen Rydell, "Performance art? Puritans in the pulpit," History Today 45, no. 9 (1995); Bryan Crockett, "The Act of Preaching and the Art of Prophesying," The Sewanee Review 105, no. 1 (1997).

${ }^{10}$ John R. Knott, The Sword of the Spirit: Puritan Responses to the Bible (Chicago: University of Chicago Press, 1980), Chapter 2.

${ }^{11}$ Perry Miller, The New England Mind: The Seventeenth Century (Boston: Beacon Press, 1970), 300-02, $38-44$.
} 
During the later half of the seventeenth century there was a wind of change which revolutionised the homiletics of the day. ${ }^{12}$ There was distaste for both baroque and Puritan sermons and instead came preaching marked by clarity, plain speech, and appropriate fervour. ${ }^{13}$ This is usually described as the neoclassical sermon and has been described in depth by Lessenich. ${ }^{14}$

This can be seen as part of a broader change in use of language as is seen in the Royal Society. Thomas Sprat spoke of the Society's determination:

...to reject all the amplifications, digressions and swellings of style: to return back to the primitive purity, and shortness, when men deliver'd so many things, almost in an equal number of words. They have exacted from all their members a close, naked, natural way of speaking; positive expressions; clear senses; a native easiness: bringing all things as near the Mathematical plainness as they can... ${ }^{15}$

While the Royal Society is often regarded as an influence on preaching Edwards argues 'that both movements were responses to the same social forces rather than one being an outgrowth of the other. ${ }^{16}$ There is a connection here with the new logic of the day. What Howell calls the 'new rhetoric' was opposed to syllogistic arguments and preferred a process of inference and induction rather than deduction, as well as a simplified language. ${ }^{17}$

This is part of a wider critique of the traditional use of rhetoric: in an increasingly rationalistic and scientific age rhetoric was seen to be the use of words to mislead,

\footnotetext{
${ }^{12}$ See Howell, Logic, Chapter 6.

${ }^{13}$ Edwards, History of Preaching, 392.

${ }^{14}$ Rolf Peter Lessenich, Elements of Pulpit Oratory in Eighteenth-Century England, 1660-1800 (Koln, Wien: Bohlau Verlag, 1972).

${ }^{15}$ Thomas Sprat, The History of the Royal-Society of London (London: T. R., 1667), 113. Also see Tina Skouen, "Science versus Rhetoric? Sprat's History of the Royal Society Reconsidered," Rhetorica: A Journal of the History of Rhetoric 29, no. 1 (2011).

${ }^{16}$ Edwards, History of Preaching, 396.

${ }^{17}$ Howell, Logic, 441-47.
} 
especially by raising the passions. ${ }^{18}$ So Locke had previously criticised any use of rhetoric as something that obscured clear meaning:

... all the Art of Rhetorick, besides Order and Clearness, all the artificial and figurative application of Words Eloquence hath invented, are for nothing else but to insinuate wrong Ideas, move the Passions, and thereby mislead the Judgement. ${ }^{19}$

An articulation of the newer plain style is given by John Wilkins in his Ecclesiastes. ${ }^{20}$ Wilkins recommends a structure that is not dissimilar to that of the Puritan sermon, but the style is clearly different and corresponds to the new science and learning of the day. ${ }^{21}$ Rivers says that the publishing history of Wilkins' book indicates the propagation of latitudinarian 'reasonable' theology and Morrissey suggests this shows a greater movement away from a Puritan emphasis of dependence on God's working through his word by his Spirit. ${ }^{22}$

This neoclassical sermon found its greatest exemplars in Robert South, Isaac Barrow, and especially John Tillotson. ${ }^{23}$ So Edwards says of Tillotson that he 'carried plainness to the extreme of actively seeking to avoid any expression that was either dramatic or poetic. ${ }^{24}$ Oliver Goldsmith commented in the mid-eighteenth century that Tillotson was an exemplar of reasoning but lamented his 'long, dry and sometimes tedious discussions', and his 'cool phlegmatic manner. ${ }^{25}$ Old summarises that Tillotson

\footnotetext{
${ }^{18}$ France, "Rhetoric," 498-99.

${ }^{19}$ Locke, Essay, III.x.34: 508.

${ }^{20}$ John Wilkins, Ecclesiastes, or, a Discourse Concerning the Gift of Preaching as it Falls under the Rules of Art (London: M. F., 1646).

${ }^{21}$ Howell, Logic, 456-57.

${ }^{22}$ Rivers, Reason, Grace and Sentiment, Vol 1, 38-39. Morrissey, "Scripture, Style and Persuasion," 70405.

${ }^{23}$ Smyth also suggests an earlier example of Archbishop Ussher, Charles Smyth, The Art of Preaching: A Practical Survey of Preaching in the Church of England, 747-1939 (London: S.P.C.K., 1940), 100.

${ }^{24}$ Edwards, History of Preaching, 413.

${ }^{25}$ Oliver Goldsmith, Collected Works, ed. A. Friedman (Oxford: Clarendon Press, 1966), Volume 1, 482.
} 
'became for his age the paragon of polite preaching', but that his prosaic prose 'had little to fire the imagination or warm the heart. ${ }^{26}$

Rivers shows that these criticisms did not apply to all latitudinarian preachers. Indeed they did not neglect the affections completely and spoke of the need to arouse their own and those of their listeners. But their emphasis was firmly on rational persuasion that would convince the understanding. ${ }^{27}$

\subsection{Preaching in the eighteenth-century}

The eighteenth century began with a continuation of the streams of preaching outlined above. $^{28}$ The neoclassical sermon continued to have great dominance, and this went hand-in-hand with the rise in desire for 'reasonable' and 'moral' religion we have previously observed. Ihalainen states:

The primary duty of a latitudinarian preacher was to persuade the public to choose moral reform and the Christian life, to teach private and social virtues, and to educate people on their duties. ${ }^{29}$

There has been a longstanding view that the archetypal preacher in the early eighteenth century gave only a moral lecture. So Downey says, 'The church seemed almost to become a society for the reformation of manners. ${ }^{30}$ In addition sermons were seen as devoid of any passion: Downey again says the church was dominated by 'a theology

\footnotetext{
${ }^{26}$ Old, Reading and Preaching, Vol 4, 367-68.

${ }^{27}$ Rivers, Reason, Grace and Sentiment, Vol 1, 50-53.

${ }^{28}$ See O. C. Edwards Jr., "Varieties of Sermon: A Survey of Preaching in the Long Eighteenth Century," in Preaching, Sermon and Cultural Change in the Long Eighteenth Century, ed. Joris van Eijnatten (Leiden: Brill, 2009); Lori Anne Ferrell and Peter E. McCullough, "Revising the Study of the English Sermon," in The English Sermon Revised: Religion, Literature and History, 1600-1750, ed. Lori Anne Ferrell and Peter E. McCullough (Manchester: Manchester University Press, 2001).

${ }^{29}$ Pasi Ihalainen, "The Enlightenment Sermon: Towards Practical Religion and a Sacred National Community," in Preaching, Sermon and Cultural Change in the Long Eighteenth Century, ed. Joris van Eijnatten (Leiden: Brill, 2009), 229.

${ }^{30}$ James Downey, The Eighteenth Century Pulpit: A Study of the Sermons of Butler, Berkeley, Secker, Sterne, Whitefield and Wesley (Oxford: Clarendon Press, 1969), 10.
} 
based upon reason, and a preaching that was unimpassioned', which 'stemmed largely from the desire to avoid the kind of fanaticism and intolerance which had been such a horrific part of the religion of the previous age. ${ }^{, 31}$

However Brinton argues that is something of a misconception. It is true, he says, that 'the moral essay became a model for preaching', but that it is wrong that this preaching does not involve the passions. Rather he argues:

The passions or affections which eighteenth-century British preaching attempts to arouse are to some extent milder or subtler ones than those which are the focus of attention in more evangelical preaching or in classical rhetoric - for example benevolence, sympathy, fellow-feeling, and the like and when there are attempts to arouse such passions as fear or indignation the attempt is usually to arouse them in milder or subtler ways and degrees. $^{32}$

We should note here the connection with the new philosophy of the passions we observed in the last chapter. Brinton goes on to suggest that this is akin to Stoic rhetoric especially that of Seneca.

Similarly Deconinck-Brossard argues there was recognition of the need to arouse the motivational powers of the passions. ${ }^{33}$ This linked with the understanding of the passions as the 'active powers' of a person without which reason could have little effect. As Lessenich says, 'a dry and barren sermon was, for all its logic, inefficient. ${ }^{34}$ This is seen in preachers such as Francis Atterbury ${ }^{35}$ who continued the emphasis on clarity, but introduced a degree of passion in his delivery. ${ }^{36}$

\footnotetext{
${ }^{31}$ Ibid., 13.

${ }^{32}$ Brinton, "Passions," 51-54.

${ }^{33}$ Francoise Deconinck-Brossard, "The Art of Preaching," in Preaching, Sermon and Cultural Change in the Long Eighteenth Century, ed. Joris van Eijnatten (Leiden: Brill, 2009), 120.

${ }^{34}$ Lessenich, Pulpit Oratory, 21-22.

${ }^{35}$ Bishop of Rochester (1662-1732)

${ }^{36}$ Lessenich, Pulpit Oratory, 39.
} 
Within this inclusion of passion however moderation and appropriateness were key words: the neoclassical style avoided extremes and, while arousing the gentler passions, avoided any emotional appeal. ${ }^{37}$ This linked with views on delivery: written sermons were the norm and extemporaneous delivery was suspiciously regarded as it 'smacked of sectarian "enthusiasm". ${ }^{38}$ Defoe compares the dissenting preaching of his day with the Puritans of the previous century, saying the Puritans, 'preach'd their Sermons, rather than read them in the Pulpit; they spoke from the Heart to the Heart, nothing like our cold Declaiming Way, entertain'd now as a Mode, and read with a Flourish. ${ }^{39}$

Later in the century Goldsmith wrote of typical Anglican sermons that they are 'dry, methodical and unaffecting; delivered with the most insipid calmness. ${ }^{40}$ Goldsmith points to the serious possibility that if the preacher should make the effort to look at his congregation he may well find them sleeping - represented in Hogarth's famous engraving of The Sleeping Congregation (1736).

Smyth points out that concern over the moralistic tendency was recognised by some in official positions, such as the Bishop of London who wrote to his clergy saying, 'it must always be remember'd in the first Place, that we are Christian Preachers, not barely Preachers of Morality. ${ }^{41}$ Downey's conclusion though is that, 'The years 1720-40 are the period of greatest vogue for Tillotsonian theology and ethical preaching'; and as result sermons were devoid of both mystery and passion. ${ }^{42}$

Within some quarters of dissent there was a continuation of elements of Puritan preaching including some its less appealing aspects. So Milner writes:

\footnotetext{
${ }^{37}$ Ihalainen, "Enlightenment Sermon," 229.

${ }^{38}$ Deconinck-Brossard, "Art of Preaching," 121.

${ }^{39}$ Defoe, Present State, 289.

${ }^{40}$ Goldsmith, Collected Works, Volume 3, 151.

${ }^{41}$ Smyth, Art of Preaching, 163. Edmund Gibson, Directions given by Edmund Lord Bishop of London to the Clergy of his Diocese (London: S. Buckley, 1724), 13.

${ }^{42}$ Downey, Eighteenth Century Pulpit, 19-20.
} 
The principal fault of the nonconformist divines was a disposition to expand their subjects to their widest extent; not merely to illustrate the general sentiment of the text, but to eke out a meaning from its minutest parts, and if possible extract a lesson from the most obstinate word and barren particle. ${ }^{43}$

As the eighteenth century progressed however there was a rise in heartfelt preaching. This was a trend which developed within continental pietist circles and then found full flower in the evangelical revivals. ${ }^{44}$ Greater attention was paid to the delivery of the sermon from mid-century onwards. This was in many ways stimulated by the evangelical revivals leading Anglicans to debate issues of presentation while avoiding enthusiasm. ${ }^{45}$ Lessenich points to the example of John Mason, a nonconformist divine who trained students for the ministry, who drew from classical views on delivery in use of voice and gesture. ${ }^{46}$

The previous concern with rhetoric obscuring meaning by raising the passions started to be challenged. Aarsleff points to 'rhetorical expressivism' where emotion was readmitted into the use of language. There were early elements of this within the PortRoyal Logic and elsewhere and then clearer statements by Berkeley in his Treatise Concerning the Principles of Human Knowledge (1710). ${ }^{47}$ The result was a view that communication of ideas was not the only purpose of language; it was also to appropriately raise passion and arouse action.

This developed into a theory of sentimental oratory and 'performance' in the pulpit. Roodenburg points to the Scottish minister James Fordyce as the first theoretician on

\footnotetext{
${ }^{43}$ Milner, Watts, 204.

${ }^{44}$ Hughes Oliphant Old, The Reading and Preaching of the Scriptures in the Worship of the Christian Church. Volume 5, Moderatism, Pietism, and Awakening (Grand Rapids: W.B. Eerdmans, 1998), 69-106. Jonathan Strom, "Pietism and Revival," in Preaching, Sermon and Cultural Change in the Long Eighteenth Century, ed. Joris van Eijnatten (Leiden: Brill, 2009).

${ }^{45}$ Paul Goring, "Anglicanism, Enthusiasm and Quixotism: Preaching and Politeness in Mid-Eighteenth Century Literature," Literature and Theology 15, no. 4 (2001).

${ }^{46}$ Lessenich, Pulpit Oratory, 131.

${ }^{47}$ Aarsleff, "Language," 455-56.
} 
this topic in his work An Essay on the Action Proper for the Pulpit (1753). ${ }^{48}$ Fordyce's view was that sermons should be 'emotionally contagious', and that a preacher's emotions should be manifested through his body. This links with the more positive view of passions that had developed through the eighteenth century. ${ }^{49}$

While this was a new theory of preaching, it had precedents in the Puritans. Perkins had stated the need for the preacher to feel, and so express, his emotional state: 'Therefore what motions a sermon doth require, such the Preacher shall stirre up privately in his owne mind, that hee that he may kindle up the same in his hearers. ${ }^{50}$ Roodenburg points to this key development through the eighteenth century:

Once the emotional accessibility of the sermon was recognised as being no less, or even more, important than its rational accessibility, it was the preacher's sensibility that was put forward. ${ }^{51}$

Lessenich summarises the eighteenth century sermon with two pairings of forbidden extremes. ${ }^{52}$ The first is dryness and ecstasy. It was widely recognised that dryness was a common problem as noted above, but there was equal concern to avoid the ecstasy associated with revival preaching. The second pairing is meanness and affectation. Meanness of style was condemned for being crude and impolite, and was an accusation often made of Wesley and Whitefield. Affectation however was artificial and pretentious; what was aimed for was a natural and authentic delivery.

\footnotetext{
${ }^{48}$ Herman Roodenburg, "Si vis me flere...: On Preachers, Passions and Pathos in Eighteenth-Century Europe," in Myths, Martyrs, and Modernity (Leiden: Brill, 2010), 609-10.

49 This theory was later developed by Thomas Sheridan in Lectures on Elocution, (1762), and by Hugh Blair in Lectures on Rhetoric and Belles Lettres (1783). For further discussion see Paul Goring, The Rhetoric of Sensibility in Eighteenth-Century Culture (Cambridge: Cambridge University Press, 2005).

${ }^{50}$ Perkins, Prophecying, 140.

${ }^{51}$ Herman Willem Roodenburg, "From Embodying the Rules to Embodying Belief: On EighteenthCentury Pulpit Delivery in England, Germany and the Netherlands," in Preaching, Sermon and Cultural Change in the Long Eighteenth Century, ed. Joris Van Eijnatten (Leiden: Brill, 2009), 341.

${ }^{52}$ Lessenich, Pulpit Oratory, Chapter 5.
} 


\section{Watts and preaching}

\subsection{Introduction}

While Watts is best known for his hymns, and then his theological and educational works, it is important to remember that he saw himself first as a pastor and hence a preacher. He published three volumes of sermons, often motivated by his periods of absence from his church because of illness, so that his congregation could read him when they could not listen to him, as well as sermons given at public meetings. A variety of other sermons are also available, including manuscripts of notes taken by Lady Abney during his sermons. ${ }^{53}$

Watts also wrote works that explained and propounded his homiletical theory. His Humble Attempt toward the Revival of Practical Religion (1731) was prompted by the work of Strickland Gough. ${ }^{54}$ Gough's recommendations in the light of his analysis of the weaknesses of the dissenting church included shorter, clearer sermons and rational worship. ${ }^{55}$ Watts responded with his own analysis for decline which emphasised that the 'great and general reason is the decay of vital religion in the heart and lives of men."

For Watts the purpose of dissent was to better promote such vital religion, and if this was not being done then he says it is not surprising that people leave for the established church given the inconveniences that dissent brings. His work then is an address both to the people and to ministers to 'use all just and proper efforts for the recovery of dying religion in the world. ${ }^{57}$ We will examine this work specifically for his comments on preaching. Watts also speaks about communication, including that of the pulpit, in The Improvement of the Mind $(1741)^{58}$ and in his Rational Foundation of a Christian

\footnotetext{
${ }^{53}$ See Gunn, "Manuscript Sermons."

${ }^{54}$ Gough, Enquiry.

55 Ibid., 39.

${ }^{56}$ Watts, Works, 'Humble Attempt', Volume 3, xi.

${ }^{57}$ Ibid., 'Humble Attempt', Volume 3, xi.

${ }^{58}$ The second part was published posthumously in 1751, but the work was written earlier; one section is listed as being written in 1718, ibid., 'Improvement of the Mind', Volume 5, 351.
} 
Church (1747). We will examine this work as well as Watts' own sermons, and draw on comments in his wider writings.

There are clearly many influences on Watts' thinking on preaching. He especially mentions Richard Baxter, Bishop Wilkins' work Ecclesiastes ${ }^{59}$, Archbishop Tillotson, and John Jennings, for whose work he wrote a preface. ${ }^{60}$ He was also aware of continental pietism and arranged for a letter on preaching by August Hermann Francke to be attached to Jennings' work.

Rivers has noted that Watts' homiletical approach is derived from his understanding of religious psychology. Rivers summarises:

Watts argues in effect for both a revival of the Puritan tradition of experimental preaching and a reinterpretation of it in the light of contemporary theorising about the inter-relation of the faculties. ${ }^{61}$

In particular Rivers highlights Watts' desire for preachers to engage each of the human faculties and use appropriate rhetoric to do so. ${ }^{62}$ In what follows we are treading a similar path to Rivers' work but in greater detail and with more focus on the influence of Watts' particular views of reason and passion.

\subsection{Overview}

In many ways Watts fitted within the frame of the neoclassical sermon of his day. He distanced himself from aspects of Puritan preaching and emphasised the need for clear language. Speaking of the classic Puritan sermon he compares their numerous subpoints to Ezekiel's vision of dry bones and says, 'there were very many in the valley,

\footnotetext{
${ }^{59}$ Watts' annotated copy of this work is available in the Dr Williams's Library, London, UK.

${ }^{60}$ John Jennings, Two Discourses: The First Of Preaching Christ; the Second Of Particular and Experimental Preaching (London: John and Barham Clark, 1723). Watts also recommends this work in Watts, Works, 'Humble Attempt', Volume 3, 15.

${ }^{61}$ Rivers, Reason, Grace and Sentiment, Vol 1, 189.

${ }^{62}$ Ibid., 190.
} 
and lo, they were very dry. ${ }^{63}$ However he also says that to their credit these sermons contained substantial knowledge aimed at informing people; a point he says is not true of many sermons of his day.

For Watts the preacher must be well trained in the knowledge of grammar and logic, and well informed of other commentators, but he must use such knowledge judiciously in the pulpit always being mindful of the needs of his listeners. ${ }^{64}$ Rivers points out that this focus on the needs and capacity of the listener (or reader) is true of all of Watts' works, and is an application of his own principle of utility. ${ }^{65}$

Watts also spoke of the need for clear and plain language and said that this was hard work to attain as seen in the following poem (the last lines of which are a translation of Horace):

Smooth be your style, and plain and natural, To strike the sons of Wapping or Whitehall. While others think this easy to attain, Let them but try, and with their utmost pain They'll sweat and strive to imitate in vain. ${ }^{66}$

Watts argued that preachers should order their material clearly and helpfully to aid the memory of their congregation and says that Tillotson was a good example of this. ${ }^{67}$ Analysis of Watts' own sermons shows that he has no one structure but commonly follows the model of establishing a doctrine and then articulating its uses. In the uses section he recommends application to different categories of listener. ${ }^{68}$ This usually results in sermons with several headings.

\footnotetext{
${ }^{63}$ Watts, Works, 'Improvement of the Mind', Volume 5, 347-48.

${ }^{64}$ Ibid., 'Humble Attempt', Volume 3, 8.

${ }^{65}$ Rivers, Reason, Grace and Sentiment, Vol 1, 174.

${ }^{66}$ Watts, Works, 'Improvement of the Mind', Volume 5, 347-48.

${ }^{67}$ Ibid., 'Improvement of the Mind', Volume 5, 281.

${ }^{68}$ Ibid., 'Humble Attempt', Volume 3, 15.
} 
An example is a sermon on the atonement of Christ. ${ }^{69}$ Watts divides the sermon into three sections:

1. To explain more at large the manner in which I conceive Christ to become an atonement or propitiation for our sins.

2. To give some reasons to prove, that he is ordained of God, and set forth or offered to the world under this character,

3. I shall shew what glorious use is made of this doctrine throughout the whole christian life.

He says that he knows such divisions and headings are unfashionable in his day. This, he believes, is because of 'a humorous and wanton contempt of the customs and preaching of our fore-fathers. ${ }^{70} \mathrm{He}$ acknowledges that many Puritans went too far in their divisions, use of syllogisms, careful definitions, and coarseness of style. However he thinks there has been too much of an over-reaction against this.

Watts comments on rhetoric, or 'the art of persuading', and says that it has three elements:

1. Conveying the sense of the speaker to the understanding of the hearers in the clearest and most intelligent manner by the plainest expressions and the most lively and striking representations of it, so that the mind may be thoroughly convinced of the thing proposed. 2. Persuading the will effectually to choose or refuse the thing suggested and represented. 3 . Raising the passions in the most vivid and forcible manner, so as to set all the soul and every power of nature at work, to pursue or avoid the thing in debate. $^{71}$

We see here the holistic view Watts had in addressing the mind, will and passions of the hearer. This clearly flows from his understanding of human nature which we have seen in the last two chapters. We will examine elements of this in more detail below.

\footnotetext{
${ }^{69}$ Ibid., 'Sermons', Volume 1, 368.

${ }^{70}$ Ibid., 'Improvement of the Mind', Volume 5, 350.

${ }^{71}$ Ibid., 'Improvement of the Mind', Volume 5, 311.
} 
Watts gives advice on language and style that fits well with Lessenich's forbidden extremes: he warns against affectation and copying the "pomp and magnificence of the theatre', and also against 'familiarity and meanness', which would sink below the dignity of the topic and office. ${ }^{72}$ As we will see, however, for Watts this means a more emotive and forceful style than the average neoclassical sermon.

In this regard Watts stood against what he saw as the prevalent preaching style of his day which he called 'The harangue' ${ }^{73}$ This is a smooth style of delivery with no headings of content to break it up. Watts says it 'glides over the ear like a rivulet of oil over polished marble, and like that too, leaves no trace behind it'; the listener may be 'pleased perhaps with the music of your voice as with the sound of a sweet instrument, and they mistook that for devotion; but their heads are dark still, and their hearts earthly. ${ }^{74}$

His main concern is that nothing is learnt and so nothing is achieved:

When you brush over the closed eyelids with a feather, did you ever find it give light to the blind? Has any of your soft harangues, your continued threads of silken eloquence ever raised the dead $?^{75}$

As result in speaking to preachers Watts says:

Do not say within yourself, How much or how elegantly I can talk upon such a text, but What can I say most usefully to those who hear me, for the instruction of their minds, for the conviction of their consciences, and for the persuasion of their hearts... not what fine things I can say, either in way of criticism or philosophy, or in way of oratory or harangue, but what powerful words I can speak to impress the consciences of them that hear with a serious and lasting sense of moral, divine and eternal things. ${ }^{76}$

\footnotetext{
72 Ibid., 'Humble Attempt', Volume 3, 22.

${ }^{73}$ The word 'harangue' meant a popular oration or speech. See Johnson, Dictionary, Volume 1, 'Harangue'.

${ }^{74}$ Watts, Works, 'Improvement of the Mind', Volume 5, 348-49.

${ }^{75}$ Ibid., 'Improvement of the Mind', Volume 5, 349.

${ }^{76}$ Ibid., 'Humble Attempt', Volume 3, 8.
} 
Speaking from a prepared manuscript was the preferred method among rational dissenters who were seeking to distance themselves from Puritanism and present a learned ministry. ${ }^{77}$ Watts by contrast recommended preparing headings but then speaking extempore. As we will see this is particularly because of the link with expressing passion in preaching which Watts felt was inhibited by reading a manuscript.

In summary Watts' approach was broadly neoclassical in style but with some significant differences. While criticising the Puritan branching sermon he follows its approximate shape but simplifies it. He is also part of the growing criticism of the eloquent sermons of the day for their focus on rhetoric over content and their aim of entertainment over edification. ${ }^{78}$ Everything for Watts is aimed at the informing and arousing of his listeners for their spiritual good. As he asks in one of his lists of questions for students: 'Is my chief design, in chusing my subject and composing my sermon, to edify the souls of men? ${ }^{79}$

\subsection{Reason in preaching}

Watts' view of the role of reason and its link with preaching begins with his instructions for the minister's private reading which includes logic, mathematics, philosophy, Biblical languages, etc. The reason for such study is explained in this way:

Among these some are necessary to improve the reasoning faculty, to teach us to distinguish truth from falsehood, and to judge aright concerning any subjects that are proposed to us. ${ }^{80}$

The minister must be someone trained in right use of reason as a foundation for his ministry, and this is then outworked in the recommendations that follow below.

\footnotetext{
${ }^{77}$ Daniel E. White, Early Romanticism and Religious Dissent (Cambridge: Cambridge University Press, 2006), 47.

${ }^{78}$ See Strom, "Pietism and Revival."

${ }^{79}$ Watts, Works, 'Questions', Volume 3, 557.

${ }^{80}$ Ibid., 'Humble Attempt', Volume 3, 5.
} 
Secondly a sermon must serve the reasoned understanding of the listener. Watts lambastes the preacher of the harangue who makes his congregation feel something but learn nothing. Everything in the preacher's use of language and structure is to serve clarity and hence the understanding of the hearer. He emphasises:

You must break the bread of life into pieces to feed children with it, and part your discourses into distinct propositions to give the ignorant a plain scheme of any one doctrine, and enable them to comprehend or retain it. ${ }^{81}$

As people must be convinced in their own mind, using their own reason, sermons must involve clear and persuasive logic:

Since you have to do with reasonable creatures in your sacred work, let your manner of speaking be rational, and your arguments and inferences just and strong; that you may effectually convince your hearers of the truth of what you deliver, in your ministrations of the gospel. ${ }^{82}$

This is also seen in comments on use of language. We previously saw how Watts followed Locke in his view of clear and distinct ideas. ${ }^{83}$ This results in his encouraging preachers to make sure they have 'distinct ideas' which they communicate clearly, rather than words without ideas. He says:

Seek to obtain a perspicuous style and a clear and distinct manner of speaking, that you may effectually impress the understanding, while you pronounce the words; that you may so exactly imprint on the mind of the hearers, the same ideas which you have conceived, that they may never mistake your meaning. ${ }^{84}$

The desire to serve the listener's understanding and memory is also seen in Watts' recommendations on structuring sermons we noted above.

\footnotetext{
${ }^{81}$ Ibid., 'Improvement of the Mind', Volume 5, 350.

${ }^{82}$ Ibid., 'Humble Attempt', Volume 3, 20.

${ }^{83}$ See chapter 2 , section 2.3 .

${ }^{84}$ Watts, Works, 'Humble Attempt', Volume 3, 20.
} 
Thirdly Watts comments on the use of reason and the light of nature in a supportive role to revelation. A preacher is encouraged to show how reason teaches the same doctrines and duties as the gospel, even if it cannot discover them all. Hence Watts says:

It is good to impress the conscience as well as instruct the understanding by the two great lights God has given us, (viz.) reason and revelation. Two such pillars will support the structure of religion better than one. ${ }^{85}$

Watts is aware of potential criticisms in utilising reason in this way. We see an example in Ruin and Recovery where Watts says that in arguing from reason some will say, 'we set a candle before the noon-day sun.' His response shows the supplementary view of reason we have previously seen: 'to shew that reason goes a great way to teach and prove what scripture asserts. ${ }^{, 86}$

So Watts sees a preacher utilising natural reason where appropriate, but he also insists that the deficiencies of reason and the superiority of revelation be enforced. Reason plays a vital role but for Watts the revealed gospel contains, 'the appointed arguments of our holy religion.' Indeed he goes on to insist on the gospel as the effectual means of salvation and to disparage the preaching of natural theology alone. A preacher may have the greatest of insight, and preach with the highest of rhetoric but:

I am fully persuaded you would never reconcile one soul to God, you would never change the heart of one sinner, nor bring him into the favour of God, nor fit him for the joys of heaven, without this blessed gospel which is committed to your hands. ${ }^{87}$

Later Watts comments on his twofold approach:

God forbid that we should abandon those arguments, drawn from the nature of things, and from human reason: The gospel does by no means exclude

\footnotetext{
${ }^{85}$ Ibid., 'Humble Attempt', Volume 3, 8.

${ }^{86}$ Ibid., 'Ruin and Recovery', Volume 6, 247.

${ }^{87}$ Ibid., 'Humble Attempt', Volume 3, 11.
} 
them, but clears and enlightens and advances them all; and gives them tenfold power for the purposes for which they are designed. ${ }^{88}$

So Watts is for the judicious use of natural theology, but against an overall reliance on it. We can see an example of this in a sermon on 'Christian Fellowship' in which Watts argues for the organisation and working of a local church. His summary shows his approach:

How beautiful is the order of the gospel, and the fellowship of a christian church? How strong and plain are the foundations, and the grounds of it? It is built on eternal reason, and the relations of things, as well as on the word of God. How happy it is that the very light of nature dictates to christians far the greatest part of those duties which church fellowship requires, supposing still that the revealed doctrines and sacraments of christianity are first known and acknowledged. ${ }^{89}$

Hence in preaching Watts sees reason as playing an essential but ultimately supportive role to the revelation of the gospel. We remember our previous discussion on Watts' view of the role of reason: its usefulness but weaknesses and the overlap with but superiority of revelation in chapter 2 . Here we see his nuanced position on these foundational topics worked out in homiletical practice.

Fourthly, Watts is keen that the preacher shows the reasonableness of the doctrine he is proclaiming. This may be of a foundational nature as to reasons for the faith:

Let them first know why they are christians, that they may be firmly established in the belief and profession of the religion of Christ; that they may be guarded against all the assaults of temptation and infidelity in this evil day, and may be able to render a reason of the hope that is in them. ${ }^{90}$

\footnotetext{
${ }^{88}$ Ibid., 'Humble Attempt', Volume 3, 12.

${ }^{89}$ Ibid., 'Sermons', Volume 1, 838-39.

${ }^{90}$ Ibid., 'Humble Attempt', Volume 3, 15.
} 
An example of this is the extraordinary gifts of the Spirit given to the early church such as healing. This miraculous activity confirms the truth of the gospel and so leads our reason to believe it is divine. ${ }^{91}$

Watts also encourages preachers to show the reasonableness of a doctrine even when it could not be discovered by the light of nature. Watts says of teaching certain doctrines, 'it is a most excellent and useful design, now and then, to shew how consistent and harmonious they are with reason. ${ }^{92}$ Again we remember our discussion in chapter 2 of Watts' view of the reasonableness of Christian doctrine and his own works attempting to vindicate orthodox belief on the basis of human reason. That position is here being applied to instruction in homiletics.

Lastly we note Watts' concern that despite the use of reason the preacher remains dependent on the work of the Holy Spirit. We previously saw how he believed the use of reason and the work of the Spirit went hand-in-hand. ${ }^{93}$ Watts then encourages preachers to be dependent on the Spirit both for their own understanding but also for aid in composing their sermons:

... seek the direction and assistance of the Spirit of God, for inclining your thoughts to proper subjects, for guiding you to proper Scriptures and framing your whole sermon both as to the matter and manner that it may attain the divine and sacred ends proposed. ${ }^{94}$

The working of the Spirit is then seen to be essential for preaching to achieve its purpose: 'without the influences of the Spirit of God, it will have little effect to draw sinners unto Christ. ${ }^{95}$ This leads Watts to urge preachers to call on God:

\footnotetext{
${ }^{91}$ Ibid., 'Sermons', Volume 1, 793.

92 Ibid., 'Humble Attempt', Volume 3, 23.

${ }^{93}$ Chapter 2, section 7.

${ }^{94}$ Watts, Works, 'Humble Attempt', Volume 3, 7.

95 Abney, "Sermon Notes," 360.
} 
If we should have reason to fear that the Spirit of God is much departed from others, let us cry with great earnestness, that the Spirit may never leave our assemblies, and abandon us to labour in vain without his influences. ${ }^{96}$

\subsection{Passion in preaching}

We can see Watts' view of the place of the passions influencing his view of preaching in a number of ways. First he emphasises the need for the preacher himself to have vital, experimental religion, and so he should take heed to his own faith. This specifically includes regular examination of the affections of the preacher and encouragement of the love of God. For example:

Call your own soul often to account; examine the temper, the frame and the motions of your own heart with all holy severity. ... Be tenderly sensible of every wandering affection toward vanity, every deviation from God and your duty, every rising sin, every degree of growing distance from God. ${ }^{97}$

The result, says Watts, will be shown in all the minister's duties but especially in his preaching: 'a word coming from the heart will sooner reach the heart.'

Secondly, while Watts insists on persuasive logic in sermons, he believes that such logic, while foundational, is not enough; rather the passions must be addressed directly. This flows from his understanding of the power the sinful passions can exercise over the understanding that we saw in chapter 2 :

A mere conviction of the reason and judgment, by the strongest arguments, is hardly sufficient, in matters of piety and virtue, to command the will into obedience; because the appetites of the flesh, and the interests of the world are ingaged on the opposite side. ... The God of nature therefore has furnished mankind with those powers, which we call passions, or affections of the heart, in order to excite the will with superior vigour and activity to avoid the evil and pursue the good. Upon this account the preacher must learn to address the passions in a proper manner... ${ }^{99}$

\footnotetext{
${ }^{96}$ Watts, Works, 'Rational Foundation', Volume 6, 109.

${ }^{97}$ Ibid., 'Humble Attempt', Volume 3, 3.

${ }^{98}$ Ibid., 'Humble Attempt', Volume 3, 3.

${ }^{99}$ Ibid., 'Humble Attempt', Volume 3, 22.
} 
In practice this means that the preacher should raise the passions of their listeners so as to convince and convict. ${ }^{100}$ The assessment of a sermon then focuses on the effect on the listener's heart:

We are too often ready to judge that to be the best sermon, which has many strange thoughts in it, many fine hints, and some grand and polite sentiments. But a christian in his best temper of mind will say, "That is a good sermon which brings my heart nearer to God, which makes the grace of Christ sweet to my soul, and the commands of Christ easy and delightful". ${ }^{101}$

So Watts tells people to desire sermons which not only 'instructs the head, but strikes the heart in a powerful and affecting manner., ${ }^{102}$ There are then implications for preachers. They must:

...contrive all lively, forcible and penetrating forms of speech, to make your words powerful and impressive on the hearts of your hearers, when light is first let into the mind. Practice all the awful and solemn ways of address to the conscience, all the soft and tender influences on the heart. ${ }^{103}$

This view is seen early in Watts' life in a letter to friend as to how to persuade people of the truth. Watts suggests his friend should 'engage the affections a little' because 'affection is the great gate of entrance into the judgements of the multitude, and reason but the back door., ${ }^{104}$ This echoes an example cited by Wilkins in his influential work where reason failed but affectionate expression convinced. ${ }^{105}$ This does not mean however that reason is neglected; rather Watts insists on the logical order of the

\footnotetext{
${ }^{100}$ See Watts' example, 'The Skeleton', ibid., 'Reliquiae Juveniles', Volume 4, 497-98.

${ }^{101}$ Ibid., 'Sermons', Volume 1, xxvi.

${ }^{102}$ Ibid., 'Humble Attempt', Volume 3, 62.

${ }^{103}$ Ibid., 'Humble Attempt', Volume 3, 22.

${ }^{104}$ Wright, Watts, 43.

${ }^{105}$ Wilkins, Ecclesiastes, 106.
} 
faculties which must be followed in preaching: 'Your first business is with the understanding., 106

The focus on the primacy of understanding relates to Watts' view of the respective functions of reason and passion which we have previously outlined, and also to his concern that passion, once raised, prejudices the judgement. ${ }^{107}$ However the need to engage the affections also reflects Watts' ambiguity over the functioning of the passions in that they can influence the mind. Rather than being directed only by the mind and will, they must be engaged directly themselves because of their affect on the whole person.

We noted that Locke had said that raising the passions misleads people; by contrast Watts believes raising the passions is needed to rightly convince people. So, although Watts is greatly influenced by the 'new rhetoric' we outlined above, he retains a much greater place for the passions. So he stands apart from his age in saying:

The movements of sacred passion may be the ridicule of an age which pretends to nothing but calm reasoning. Life and zeal in the ministry of the word, may be despised by men of luke-warm and dying religion... But this very life and zeal, this sacred fervency, shall still remain one bright character of the christian preacher, till the names of Paul and Apollos perish from the church; and that is, till this bible and these heavens are no more. ${ }^{108}$

This is where Watts' doctrine of sin informs his homiletics. He reminds preachers that they are speaking to those who are pulled aside by their own sinful passions and temptations of the world:

The understanding indeed ought to be first convinced by the plainest and strongest force of reasoning; but when this is done, all the powerful motives should be used which have any just influence on human nature, all the springs of passion should be touched, to awaken the stupid and the thoughtless into consideration, to penetrate and melt the hardest heart, to

\footnotetext{
${ }^{106}$ Watts, Works, 'Humble Attempt', Volume 3, 19.

${ }^{107}$ See chapter 2 sections 4.5 and 5.1.

${ }^{108}$ Watts, Works, 'Sermons', Volume 1, pxxi-xxii.
} 
persuade the unwilling, to excite the lazy, to reclaim the obstinate, and reform the vicious part of mankind, as well as to encourage those who are humble and pious, and to support their practice and their hope. ${ }^{109}$

Here we see the outworking of Watts' view of sin and the passions that we examined in chapter 3.

Thirdly this leads on to instructions on the actual delivery of sermons. In achieving the aim of addressing the passions Watts encourages the preacher to use the language of Scripture itself. He says of the Bible:

Words of force and eloquence to charm and allure the soul, glitter and sparkle like golden ore in some peculiar parts of it. You may find there noble examples of the awful and compassionate style, and inimitable patterns of the terrible and the tender. ${ }^{110}$

Such language is to be copied by the preacher. In practice this results in Watts including impassioned language himself especially within his 'uses' section a sermon. For example in the sermon mentioned above on the atonement of Christ, within the section on uses Watts says this doctrine should be a powerful motive for repentance and forgiveness. He goes on:

And is there such an atonement made? And are there such pardons provided for such guilty wretches as I have been? Is God reconciling himself to men, and reconciling men to himself, by the bloud of Jesus? Then let my soul mourn for all her follies, her past iniquities. Let me be covered with shame, and lie in the dust at the foot of God. O let him speak forgiveness and peace to me... ${ }^{111}$

Examples like this are common in Watts' preaching. This links to his view of metaphorical language which he says is suitable 'to move, and persuade, and work on

\footnotetext{
${ }^{109}$ Ibid., 'Improvement of the Mind', Volume 5, 312.

${ }^{110}$ Ibid., 'Humble Attempt', Volume 3, 23.

${ }^{111}$ Ibid., 'Sermons', Volume 1, 396-97.
} 
the passions, as well as on the understanding. ${ }^{112}$ So in speaking of presenting Christ to a congregation he uses the analogy of how a magnet increases its attraction when encased in steel, and says: 'Jesus by his lovely nature attracts souls to him but he attracts more powerfully when he is beheld in his dying love hanging upon the cross, and bleeding for our sins. ${ }^{113}$ Hence the preacher must paint such a picture for his listeners.

The preacher should also avoid any hint of coldness or indifference but rather take joy in his task so as to affect the congregation: 'Stir yourself up to the work with sacred vigour, that the assembly may feel what you speak. ${ }^{114}$ Or, the preacher should speak 'with such a holy fervour, as to light up a divine flame of desire, hope and love, in the souls of all that hear it. ${ }^{115}$ Hence the preacher should attempt to get his heart into a 'temper of divine love' where he longs for God's honour and feels for lost sinners. There should be a great sense of the gravity of the situation, and Watts echoes Baxter in saying, 'Speak as a dying preacher to dying hearers. ${ }^{\text {,16 }}$

The preacher should then also be an 'example to the hearers' in the appropriate passionate response:

When the words freeze upon his lips, the hearts of his hearers are freezing also: But where we find devout affection mingled with solid argument in the discourse, there the lips of the preacher seem to speak light and life at once, and he helps to communicate the holy passion all around him, by feeling it first himself. ${ }^{117}$

\footnotetext{
${ }^{112}$ Ibid., 'Logic', Volume 5, 34.

${ }^{113}$ Abney, "Sermon Notes," 361.

${ }^{114}$ Watts, Works, 'Humble Attempt', Volume 3, 26.

115 Ibid., 'Love of God', Volume 2, 677.

${ }^{116}$ Ibid., 'Humble Attempt', Volume 3, 26. Baxter's famous line was that he preached, 'As a dying man to dying men', Baxter, Poetical Fragments, 40.

${ }^{117}$ Watts, Works, 'Love of God', Volume 2, 679.
} 
Here is an example of the 'emotional contagion' within a sermon which was present in Puritan thought, and would develop more fully in certain circles as the eighteenth century progressed.

In achieving this Watts seems ambivalent about the study of oratory. At one point he says that oratorical training will help the minister 'to win the hearts of his hearers, and to lead by a sweet and powerful influence on their affections, into the love and practice of religion. ${ }^{, 18}$ However says that the language of Scripture is greater than any heathen oratory: it is "warm and pathetic language, to strike the imagination or to affect the heart, to kindle the divine passions or to melt the soul.' Hearing the Biblical writers, says Watts, means the preacher would never 'mourn a want of acquaintance with Tully or Demosthenes. ${ }^{119}$

He also says that observation of the best preachers is more useful than study of oratorical technique, and more significant still is the state of the heart of the preacher:

Let all the warmest zeal for God, and compassion for perishing men, animate your voice and countenance; and let the people see and feel, as well as hear, that you are speaking to them about things of infinite moment, and in which your own eternal interest lies as well as theirs. ${ }^{120}$

Hence Watts gives an earnest plea for passionate preaching and decries the cooler approach common in his day:

Can we be content any longer to be the cold and lifeless rehearsers of the great and glorious things of our religion? Can we go on to speak to perishing sinners, who lie drowsy and slumbering on the brink of hell, in so soft, so calm and gentle a manner, as though we were afraid to awaken them? ... Who taught us any of this lazy and drowsy practice? Did God or

\footnotetext{
${ }^{118}$ Ibid., 'Humble Attempt', Volume 3, 5.

${ }^{119}$ Ibid., 'Humble Attempt', Volume 3, 24. See also Watts' recommendation of the Hebrew prophets over Horace's recommendation of Greek writers, ibid., 'Horae Lyricae', Volume 4, 321.

${ }^{120}$ Ibid., 'Humble Attempt', Volume 3, 27.
} 
his prophets, did Christ or his apostles, instruct in this modish art of still life, this lethargy of preaching. ${ }^{121}$

In this area then we see Watts' view of the appropriate excitation of the passions in practice. Such excitation in preaching, especially of love for God, is essential for the Christian life, and hence it must be part of the preacher's aim.

Lastly we see Watts' call to rely on the Spirit for effective preaching that will reach the heart. This is shown in prayer, but also in dependence on the Spirit in delivery. This may mean that the Spirit gives new forms of speech beyond what was prepared which can result in words that give greater understanding and greater effect on the passions:

Why may you not hope for some lively turns of thought, some pious new sentiments which may strike light, and heat, and life into the understandings and hearts of those that hear you. In the zeal of your ministrations, why may you not expect some bright and warm and pathetic forms of argument or persuasion to offer themselves to your lips, for the more powerful conviction of sinners, and the encouragement and comfort of humble christians? ${ }^{122}$

\section{Summary and comparison}

We have seen how Watts' views on reason and passion direct his view of preaching. Watts himself sums up his approach as a "plain and warm manner of preaching. ${ }^{123}$ Watts had moved on from the Puritan style into the neoclassical sermon of the eighteenth century, but both retained and modified a number of elements. We have noted Rivers' helpful summary that Watts sought a return to the experimental preaching of the Puritans, but with a revision of it in light of new religious psychological theory.

We must understand however that Watts' religious psychology contains significant theological elements. His view of the damage wrought by sin in overturning right reason is central to his homiletic method. Right reason must be restored, and then it must then

\footnotetext{
${ }^{121}$ Ibid., 'Love of God', Volume 2, 678.

${ }^{122}$ Ibid., 'Humble Attempt', Volume 3, 27.

${ }^{123}$ Milner, Watts, 637.
} 
dictate right passions. This relationship between the faculties means that the mind must be addressed before the passions are raised, and hence the reasoned argumentation of a sermon must be presented first and the passions engaged only after the truth has been established. However in addition to this primary place for reason, the ongoing allure of sin and its affect on the passions has implications for the rhetoric of a sermon. The preacher must fight fire with fire, using impassioned language to enter into a contest to arouse the passions on behalf of God and even convince when reasoned argument fails.

Within his day Watts' combination of reason and passion in preaching resulted in what seems to be a rare hybrid. Claims of rarity are problematic because of access to the appropriate data, and because we are dealing with matters of degree rather than presence or absence. However compared to the stereotypical sermon of the early to mideighteenth century there is a far greater emphasis in Watts on the expression of passion by the preacher and the excitation of passion in the listeners. This is clear when Watts is compared to preachers of his day such as Butler and Berkeley. ${ }^{124}$

We see Watts' awareness of this in his critique of what he sees as the cool, languid preaching around him. However this is combined with an insistence on the foundational role of reason and an orientation of homiletic technique to assist the understanding and memory of the listeners. Watts' ideal preaching combines the 'clear and distinct ideas' of Locke with the excited heart of the enthusiast.

There were others much closer to Watts however. Brown says that within Baptist groups there was recognition that a sermon must have 'vigour, inspiration and life' to it. ${ }^{125}$ An ordination sermon by the Baptist minister Samuel Wilson contains instruction to:

...warm your heart with Divine Truths, that you may speak feelingly and with proper Zeal and Earnestness, as one who is thoroughly concerned, in the Hand of God, to be useful to the Souls of Men. ${ }^{126}$

\footnotetext{
${ }^{124}$ See Downey, Eighteenth Century Pulpit.

${ }^{125}$ Raymond Brown, "Baptist Preaching in Early 18th Century England," Baptist Quarterly 31, no. 1 (1985): 14.

${ }^{126}$ Samuel Wilson, The Duties of a Pastor and Deacons (London: John Wilson, 1736), 19.
} 
However there is a virtual absence of discussion of the role of reason in this sermon.

There are similar themes too in the instruction of the poet and religious writer Sir Richard Blackmore. ${ }^{127}$ Blackmore had similar views to Watts on sermon structure and the need for the preacher to show emotion in his delivery and so stir the hearts of his listeners. ${ }^{128}$ However Blackmore shows greater concern with the art of oratory and more dependence on classical authorities.

The Calvinistic Anglican John Edwards wrote a manual on preaching in which he also encourages a logical, but heartfelt persuasion of truth. Edwards though emphasises the authority of Scripture over against reason far more than Watts, and hence was concerned that the authority of reason did not appear in sermons. ${ }^{129}$

Watts' fellow Congregationalist minister John Bradbury had a similar style in structuring his sermons, in stating and defending a doctrine and then making uses of it. His uses are also applied to different groups. However he differed in a few ways: a more strident style (reflecting very different personalities), a greater focus on proposal and defence of doctrine than on uses, and in a relative lack of pathos in his applications. ${ }^{130}$

It is not that Watts stood alone of course in his approach. There is a great similarity in Philip Doddridge, on whom Watts was influential. However, particularly in the early eighteenth century, Watts was unusual. Distinct elements were combined in his view of preaching: his modified Enlightenment view on reason, his neoclassical use of

\footnotetext{
${ }^{127}$ Richard Sir Blackmore, The Accomplished Preacher: or, An Essay upon Divine Eloquence (London: J. Downing, 1731). This was published posthumously.

${ }^{128}$ Ibid., 26-27, 57-73.

${ }^{129}$ John Edwards, The Preacher. A Discourse, Shewing, What are the Particular Offices and

Employments of those of that Character in the Church (London: J. Robinson, J. Lawrence, and J. Wyat, 1705), 46-48, 180-97.

${ }^{130}$ See for example: Thomas Bradbury, The Nature of Faith (London: John Clark, 1721). Thomas Bradbury, The Popish Doctrine of Justification by Works (London: J. Oswald, 1735).
} 
language, his Puritan focus on passion, and the new religious psychology of the faculties, all underpinned with his theological understanding of sin and regeneration.

We now turn to examine the ways in which Watts refined the Puritan view of preaching, of which he is often said to be an example of continuity. ${ }^{131}$ We must remember the variation with the large category of 'Puritan' preaching and we can only take some representative soundings, but these are still instructive.

A clear element of continuity is the close application of doctrine to different types of hearers, as recommended by Perkins, which is emphasised as essential by Watts: 'Thus you will divide the word of God aright, and give to every one their portion. ${ }^{132} \mathrm{He}$ specifically highlights this in his preface to the work by John Jennings. ${ }^{133}$

There also continuity in the need for passion within in the preacher. We saw Perkins' comments on this earlier; another example is John Owen who said: 'If the word doth not dwell with power in us, it will not pass with power from us. ${ }^{, 134}$ Similarly Baxter spoke of the need 'to warm their hearts by kindling in them holy affections, as by a communication from ours. ${ }^{135}$ Watts echoes this theme in an age often antagonistic to it.

Watts also continued, and probably increased, a focus on the affective presentation of the sermon. This was not absent in Puritan preaching; Richard Baxter had said:

\footnotetext{
${ }^{131}$ For example, Davis, Watts, 134.

${ }^{132}$ Watts, Works, 'Humble Attempt', Volume 3, 15.

${ }^{133}$ Jennings, Two Discourses, xiii.

${ }^{134}$ John Owen, The True Nature of a Gospel Church and its Government (London: Printed for William Marshall, 1689), 88.

${ }^{135}$ Richard Baxter, The Reformed Pastor (Edinburgh: Banner of Truth Trust, 1974), 150. Examples of passionate language are readily found in Baxter's sermons, for example, Richard Baxter, Englands Warning-Piece (London: J. Conyers, 1678).
} 
If our words be not sharpened, and pierce not as nails, they will hardly be felt by stony hearts. To speak slightly and coldly of heavenly things is nearly as bad as to say nothing of them at all. ${ }^{136}$

While Baxter may have been something of an exceptional example in this ${ }^{137}$ there are similar sentiments in other Puritan writers on preaching. ${ }^{138}$ There is also a focus on using the language of Scripture which is seen to be more affecting than that of classical orators, just as we saw in Watts. ${ }^{139}$ For example Richard Bernard explained what the preacher should do having made his 'use' clear:

Exhort heereupon summarily repeating the reasons; enforce and enlarge some of the waightiest and stir up to the means: that affection may take hold, and endeavour be used to the thing, as well to know the duty. ${ }^{140}$

However for some Puritans logic supplanted rhetoric resulting in an absence of affective language. ${ }^{141}$ While mentioning the need for the preacher's own affection Perkins had made no comment on passion and rhetoric in his prescriptive work. ${ }^{142}$ The Directory of Public Worship focuses much more on argument of doctrines than stirring of passion in its section on preaching. ${ }^{143}$ White argues that this focus is because of the influence of Ramist logic:

\footnotetext{
${ }^{136}$ Baxter, Reformed Pastor, 117. For more on Baxter's preaching see N. H. Keeble, "Richard Baxter's Preaching Ministry: its History and Texts," The Journal of Ecclesiastical History 35, no. 4 (1984). ${ }^{137}$ See Rivers, Reason, Grace and Sentiment, Vol 1, 126. Also the comments of William Bates, $A$ Funeral-Sermon for the Reverend, Holy and Excellent Divine, Mr. Richard Baxter (London: Brab. Aylmer, 1692), 90.

${ }^{138}$ Leland Ryken, Worldly Saints: The Puritans As They Really Were (Grand Rapids: Zondervan Publishing House, 1986), 102-04. Hambrick-Stowe, Practice of Piety, 116-23. For the specific example of Richard Sibbes see Knott, Sword of the Spirit, Chapter 2.

${ }^{139}$ See for example John Clarke, Holy Oyle for the Lampes of the Sanctuarie (London: Aug. Mathewes, 1630).

${ }^{140}$ Richard Bernard, The Faithfull Shepheard: or, The Shepheards Faithfulnesse (London Arnold Hatfield, 1607), 66.

${ }^{141}$ Mitchell, Pulpit Oratory, 259.

${ }^{142}$ Perkins, Prophecying, 140-44.

${ }^{143}$ A Directory for Publique Worship of God, (London: G.M. and I.F., 1645), 13-18.
} 
Emotional values were, most assuredly, extremely important; but, by their nature they were antagonistic to the reasoning process and should be restricted essentially to a reinforcing function. ${ }^{144}$

We have seen similar comments by Watts in the need to address the understanding before the passions. However Watts gives a greater role to the place of the passions in persuasion and, as a result, greater attention to affective rhetoric. Hence it may be most accurate to say that Watts continues and develops one end of the spectrum of Puritan preaching.

It is possible that this increased focus on affective presentation reflects Watts' move away from a purely voluntaristic view of the passions which we noted in the last chapter. ${ }^{145}$ Such a move would go hand-in-hand with a greater emphasis on the stimulation of the passions within preaching, and so a greater concern with the language used which 'moves' the listeners. This may also fit with the growing view of the inherent goodness of the passions in the eighteenth century. It is difficult to map this directly onto the preaching of the day but Roodenburg suggests that it resulted in the belief that passions should be stimulated in preaching. This resulted in more attention being paid to the emotional state of the preacher and his rhetorical delivery as we noted in the introduction to this chapter. ${ }^{146}$ Watts may be an early example of such a connection. However for Watts this is only within his theological understanding of the passions, that is that they require regeneration and reordering not merely stimulating.

We also see two areas of change from Puritan preaching directed by Watts' view of reason. Watts desired a simplification of the Puritan sermon structure to aid understanding. The Puritans of course had a high view of reason, and presumably believed their sermons were perfectly understandable. However there is evidence of their complexity and prolixity: they were certainly mocked for this from those outside

\footnotetext{
${ }^{144}$ Eugene Edmond White, Puritan Rhetoric: The Issue of Emotion in Religion (Carbondale: Southern Illinois University Press, 1972), 15-16.

145 Chapter 3, Section 7.

${ }^{146}$ Roodenburg, "Preachers, Passions and Pathos."
} 
their party. ${ }^{147}$ Watts continued the Puritan concern for plain language but believed the complexity of presentation needed to be simplified to aid comprehension and memory and so resisted the branching nature of Puritan sermons derived from the logic of Ramus.

Watts also introduced a subservient but very significant place for arguments from reason, and encouraged demonstration of the reasonableness of belief and of particular doctrines. This use of reason was present in some Puritan sermons but usually to a far lesser extent. Mitchell overstates it when he says that seventeenth century Puritan preaching 'practically forbade the exercise of the intellect', but there is still some truth to this. ${ }^{148}$ Certainly Perkins had said, 'Humane wisedome must bee concealed'; private use of philosophy was allowed but it was not to be displayed in the pulpit. ${ }^{149}$ Similarly John Preston had tightly limited the use of philosophical argument so that it was not a basis for belief. ${ }^{150}$

The demonstration of the reasonability of faith had become more prominent in the preaching of later Puritans such as John Howe but there is still a marked increase in Watts. ${ }^{151}$ This reflects the differences between Watts and Puritan positions that we outlined in chapter 2. Overall we see Watts' greater receptivity to the potential of reason and therefore its use in preaching.

Lastly we note Watts' emphasis on dependence on the Spirit in aiding preaching in both its reasoning and passionate elements. In this he continues a clear Puritan theme. We previously noted that Morrissey believed the neoclassical style of plain preaching

\footnotetext{
${ }^{147}$ Davies, Worship and Theology, Vol 2, 173-74. Francis J. Bremer, Shaping New Englands: Puritan Clergymen in Seventeenth Century England and New England (New York: Maxwell Macmillan International, 1994), 26-27.

${ }^{148}$ Mitchell, Pulpit Oratory, 258.

${ }^{149}$ Perkins, Prophecying, 132-33.

${ }^{150}$ John Preston, Riches of Mercy (London: F. Eglesfield, 1658), 'A Pattern of Wholesome Words', 304 20.

${ }^{151}$ On Howe see Old, Reading and Preaching, Vol 5, 5-15. On Bunyan and Baxter see Rivers, Reason, Grace and Sentiment, Vol 1, Chapter 3.
} 
represented a step away from reliance on God by the preacher; rather it assumes the preacher has the power within himself to convince his hearers. ${ }^{152}$ In this area Watts stands apart from the neoclassical stream while still insisting on many of its facets.

Watts believed that preaching was central to the life and health of the church. Hence within his desire to see a return of God's glory to his church he wished to see a renovation of preaching. As we have seen that renovation was thoroughly guided, and indeed driven, by his view of reason and passion. He wanted to see preaching with the most convincing argument and appropriate support of natural reason, expressed in the clearest and most memorable language. In this he reflects Enlightenment thought. However he also wants sermons from men who passionately loved God, expressed in the most heartfelt words and manner, resulting in conviction and godly affection among the hearers. In this he reflects a modified Puritan position.

So Watts says of his own sermons:

I have not entertained you with lectures of philosophy, instead with the gospel of Christ; nor have I affected that easy indolence of style which is the dry delight of some modish writers, the cold and insipid pleasure of men who pretend to politeness. You know it has always been the business of my ministry to convince and persuade your souls in practical godliness, by the clearest and strongest reasons derived from the gospel, and by all the most moving methods of speech, of which I was capable; but still in a humble subserviency to the promised influences of the holy Spirit. ${ }^{153}$

\footnotetext{
${ }^{152}$ Morrissey, "Scripture, Style and Persuasion," 704-05.

${ }^{153}$ Watts, Works, 'Sermons', Volume 1, xxi.
} 


\section{Chapter 5 The Need for Praise}

\section{Introduction}

\subsection{Background}

For the wider context of singing in the church and the development of hymnody leading up to the eighteenth century the reader is referred to the appropriate literature. ${ }^{1}$ Here we will outline some of the most salient points to place Watts in context. Following the reformation in England the Calvinistic preference for psalm singing won out over the Lutheran preference for newly composed hymns. The result was that from the midsixteenth century onwards the metrical psalm reigned in English churches. ${ }^{2}$ This was for those churches which sang, as many opposed singing altogether.

During the seventeenth century however there was gradual growth in two areas, both of which Watts would revolutionise. These were the Christianisation of the psalter and the writing of hymns. The history of development and the contributions of different hymn writers are well documented by Escott and Watson. ${ }^{3}$ Both authors also note the parallel development of religious devotional poetry.

Davies outlines two distinct approaches to worship within the later seventeenth century. The high Anglican tradition often involved the chanting of the psalms and canticles which required a trained choir, although there was some congregational psalm singing

\footnotetext{
${ }^{1}$ John Julian, A Dictionary of Hymnology (London: John Murray, 1892). Louis Fitzgerald Benson, The English Hymn: Its Development and Use in Worship (New York: Hodder and Stoughton, 1915). Frederick John Gillman, The Evolution of the English Hymn (London: Allen and Unwin, 1927). Watson, English Hymn. Samuel J. Rogal, A General Introduction to Hymnody and Congregational Song (Philadelphia: American Theological Library Association, 1991). Isabel Rivers and David L. Wykes, Dissenting Praise: Religious Dissent and the Hymn in England and Wales (Oxford: Oxford University Press, 2011). Sharon Achinstein, Literature and Dissent in Milton's England (Cambridge: Cambridge University Press, 2003), Chapter 8.

${ }^{2}$ Harry Escott, Isaac Watts, Hymnographer: A Study of the Beginnings, Development and Philosophy of the English Hymn (London: Independent Press, 1962), 67.

${ }^{3}$ Ibid., Chapters 3 and 4. Watson, English Hymn.
} 
as well. There was also the use of instrumentation to accompany singing. This contrasted with the Puritan approach driven by the regulative principle. Accompaniment was not allowed and metrical psalms were only sung by the whole congregation. ${ }^{4}$ There were however occasional examples of newly composed hymns such as those by Richard Baxter and Benjamin Keach. ${ }^{5}$

At the end of the seventeenth century several entwined areas of debate must be distinguished. There is the use of newly composed hymns as opposed to metrical psalms; the freedom of interpretation of the psalms in paraphrasing them for singing; the use of instrumental music and the related issue of 'regular singing'; and lastly, the theological understanding of worship lying behind and motivating these issues. ${ }^{6}$

\subsection{Praise in the eighteenth century}

The century began with the mixed views on singing we have noted above. ${ }^{7}$ For those congregations which did sing, this was commonly regarded as the worse part of their worship which was not helped by the method of a clerk 'lining out' the psalm and the congregation singing each line back. ${ }^{8}$ Davies comments: 'The awkward inversions and

\footnotetext{
${ }^{4}$ Davies, Worship and Theology, Vol 2, 253-82.

${ }^{5}$ On Puritan worship and music see Percy Alfred Scholes, The Puritans and Music - in England and New England. A Contribution to the Cultural History of Two Nations (London: Oxford University Press, 1934).

${ }^{6}$ See overview by Elizabeth Clarke, "Hymns, Psalms, and Controversy in the Seventeenth Century," in Dissenting Praise: Religious Dissent and the Hymn in England and Wales, ed. Isabel Rivers and David L. Wykes (Oxford: Oxford University Press, 2011). On 'regular singing' see Joyce Irwin, "The Theology of "Regular Singing"," New England Quarterly 51, no. 2 (1978).

${ }^{7}$ On praise through the eighteenth century see: Rivers and Wykes, Dissenting Praise. Arnold, English Hymn. Donald Davie, The Eighteenth-Century Hymn in England (Cambridge: Cambridge University Press, 1993). Madeleine Forell Marshall and Janet M. Todd, English Congregational Hymns in the Eighteenth Century (Lexington: University Press of Kentucky, 1982). Donald Davie and Robert Murrell Stevenson, English Hymnology in the Eighteenth Century (Los Angeles: William Andrews Clark Memorial Library, 1980).

${ }^{8}$ Ian M. Green, ""All People that on Earth do Dwell. Sing to the Lord with Cheerful Voice": Protestantism and Music in Early Modern England," in Christianity and Community in the West: Essays for John Bossy, ed. Simon Ditchfield (Aldershot: Ashgate, 2001), 156-59.
} 
plodding progression of their sad doggerel were calculated to dampen the ardour of the most enthusiastic singers." 9

There was an update of the Old Version ${ }^{10}$ with a psalter by Tate and Brady published in 1700 which was in line with some of the language changes encouraged by the Royal Society. ${ }^{11}$ There were also attempts to encourage and improve the performance of psalmody, such as a series of Eastcheap lectures. ${ }^{12}$ These focussed on enforcing the duty of singing on congregations along with exhortations for better performance. There was agreement that:

The Duty of Singing in the Worship of God had been very much neglected and unskilfully perform'd among our selves, in comparison of the greater Knowledge and better Care of the foreign Churches. ${ }^{13}$

However the contributors disagreed among themselves as to the appropriate content that was to be sung. The two main positions were those advocating only psalmody, and those who believed that psalmody should be complemented by the addition of new composures.

There were similar attempts to encourage better practice within conformity such as by Dorrington. ${ }^{14}$ Dorrington was concerned to improve the praise within the Church of England and to defend its particular practices, such as use of accompanying instrumentation, while attacking the worship of dissenters. Despite such attempts Wesley was still lamenting the worship of the Church of England in the 1750s referring to 'the miserable, scandalous doggerel of Hopkins and Sternhold.' 15

\footnotetext{
${ }^{9}$ Davies, Worship and Theology, Vol 3, 65.

${ }^{10}$ By Sternhold and Hopkins.

${ }^{11}$ Escott, Hymnographer, 107.

${ }^{12}$ Practical Discourses of Singing in the Worship of God; Preach'd at the Friday Lecture in Eastcheap.

By Several Ministers, (London: J. Darby, 1708).

${ }^{13}$ Ibid., iii.

${ }^{14}$ Theophilus Dorrington, A Discourse on Singing in the Worship of God (London: H. Clark, 1704).

${ }^{15}$ John Wesley, Letters of John Wesley, ed. George Eayrs (London: Hodder \& Stoughton, 1915), 114.
} 
A variety of factors have been noted which influenced the practice of praise, and its change, in the eighteenth century. These include baroque, rationalistic, and pietist influences. ${ }^{16}$ The rise of the role of reason, and the change in views of the passions also had an effect on public worship. Davies argues that there was a change from the Puritan focus on the downward movement from God to people in word and sacrament, to a greater focus on horizontal movement between people. There was also increased subjectivity in worship, where hymns would increasingly sing of the experience of the believer using personal pronouns. ${ }^{17}$

\section{Watts and praise}

\subsection{Introduction}

Watts knew that was he was attempting was nothing less than the 'reformation of psalmody amongst the churches', and he went about it in a carefully phased way. He published Hymns and Spiritual Songs in 1707, it was revised two years later ${ }^{18}$ and went through an enormous number of editions. ${ }^{19}$ This work was divided into three sections: hymns collected from the scriptures (to accommodate those who felt that songs should be based only on the words of the Bible); hymns composed on divine subjects (which were freer compositions); and hymns prepared for the Lord's Supper (which met the felt need for suitable composures for this sacrament).

Watts had continued to encourage the singing of psalms but had given notice of his desire to reform this area as well. In 1719 he published The Psalms of David Imitated in the Language of the New Testament which also was republished many times. The first hymn book had contained some paraphrases of psalms which were later removed to the psalm book. Watts also published Divine Songs attempted in Easy Language, for the use of Children, in 1715. Watts continued to write occasional hymns, particularly as

\footnotetext{
${ }^{16}$ Irwin, "Regular Singing," 177, 82-90. Marshall and Todd, Congregational Hymns, 19-27.

${ }^{17}$ Davies, Worship and Theology, Vol 3, 99-100.

${ }^{18}$ This revision included both changing lines of hymns and the inclusion of new hymns.

${ }^{19}$ For different editions of Watts' hymns and discussion of changes in wording of hymns see Selma L. Bishop, Isaac Watts: Hymns and Spiritual Songs, 1707-1748. With a Study of Early Eighteenth-Century Language Changes (London: Faith Press, 1962).
} 
companions to some of his published sermons. Watts' published poetry, Horae Lyricae, also contained a number of hymns.

These books revolutionised the praise of the church. Many authors speak of Watts' domination of the worship of the church, especially that of dissent. England for example speaks of how 'Watts's power extended from the cradle to the grave. ${ }^{20}$ We should note that there was also strong opposition to both Watts' hymns, and especially his psalms. The concept of hymns supplementing the use of metrical psalms was more widely accepted $^{21}$, but paraphrasing the psalms as Watts did was seen to be playing fast and loose with divinely ordained songs. Hence later in the century William Romaine wrote of Watts:

As for his psalms they are so far from the mind of the Spirit, that I am sure if David was to read them, he would not know any one of them to be his.... The Scripture wants no mending, nay, it is always worse for mending. ${ }^{22}$

In the prefaces to both Hymns and Psalms Watts explained his methodology and reasoning and we shall draw on these in our discussion. With the publication of Hymns he also included an Essay towards the Improvement of Christian Psalmody which contains important arguments. We will also draw on comments Watts makes in his wider writings on the topic. In addition we will examine the lyrics of Watts' hymns and psalms themselves for what they reveal about his view of Christian praise.

\subsection{Overview}

One of Watts' well known hymns begins:

I'll praise my Maker with my breath; And when my voice is lost in Death Praise shall employ my nobler pow'rs:

\footnotetext{
${ }^{20}$ Martha Winburn England, "Emily Dickinson and Isaac Watts: Puritan Hymnodists," Bulletin of the New York Public Library (1965).

${ }^{21}$ This explains the publication of Watts' hymns before his psalms. See discussion by Escott, Hymnographer, Chapter 5.

${ }^{22}$ William Romaine, An Essay on Psalmody (London: 1775), 137.
} 
My days of praise shall ne'er be past

While life and thought and being last,

Or immortality endures. ${ }^{23}$

Here we have taste of the significance of praise for Watts: he sees the whole purpose of human existence as giving praise to God, and a prime way they do so is in using their voice in song. He defines praise in the following way:

'Tis a part of that divine worship which we owe to the power that made us:

It is an acknowledgement of the perfections of God, ascribing all excellencies to him, and confessing all the works of nature and grace to proceed from him. ${ }^{24}$

There have been many works which give an overview of Watts' hymns and the reader is referred to the most important of them. ${ }^{25}$ While Watts' reformation of praise has been well documented, relatively little attention has been paid to his underlying theology which motivated and shaped this reformation. We will give an overview of his approach here and then focus on the influence of his view of reason and passion.

Watts was critical of the praise of his day and highlights two key aspects. He says:

To see the dull indifference, the negligent and the thoughtless air that sits upon the faces of a whole assembly, while the psalm is on their lips, might tempt even a charitable observer to suspect the fervency of inward religion; and 'tis much to be feared that the minds of most of the worshippers are absent or unconcerned. ${ }^{26}$

\footnotetext{
${ }^{23}$ Watts, Works, 'Psalms', Volume 4, 139.

${ }^{24}$ Ibid., 'Reliquiae Juveniles', Volume 4, 470.

${ }^{25}$ See Escott, Hymnographer. Watson, English Hymn, Chapter 7. Bernard L. Manning, The Hymns of Wesley and Watts. Five Informal Papers (London: Epworth Press, 1942). Davis, Watts, Chapter 8.
} Kenneth Harrington Cousland, "The Significance of Isaac Watts in the Development of Hymnody," Church History 17, no. 4 (1948). J. R. Watson, "The Hymns of Isaac Watts and the Tradition of Dissent," in Dissenting praise: Religious Dissent and the Hymn in England and Wales, ed. Isabel Rivers and David L. Wykes (Oxford: Oxford University Press, 2011).

${ }^{26}$ Watts, Works, 'Hymns', Volume 4, 147. 
The two aspects then are the suspect nature of both the passions and the mind of the worshipper. Watts argues that the key fault lies in the content of what is sung: 'I have been long convinced, that one great occasion of this evil arises from the matter and words to which we confine all our songs.' Some he said were 'almost opposite the spirit of the gospel; many of them foreign to the state of the New Testament, and widely different from the present circumstances of christians. ${ }^{27}$ His answer was to provide hymns that were evangelical or gospel focussed in nature, and which expressed the thoughts and feelings of those singing. ${ }^{28}$

Watts provided these in two ways. First he argued for the composure of new hymns which reflected the dispensation of the gospel and allowed expression of Christian experience. Second, Watts argued that the psalms, while not being discarded, must be paraphrased so as to allow mention of gospel truth (such as naming Jesus), and to reflect the experience of the contemporary believer rather than that of the psalmist.

The second area applied Watts' interpretive hermeneutic to the psalms such that Old Testament types were represented by their fulfilment in his hymns. These interpretive moves are often explained in Watts' notes below each hymn. Watts explains his approach as follows:

Where the psalmist uses sharp invectives against his personal enemies, I have endeavoured to turn the edge of them against our spiritual adversaries, sin, satan, and temptation. ... Where the original runs in the form of a prophecy concerning Christ and his salvation, I have given an historical turn to the sense... When the writers of the New Testament have cited or alluded to any part of the psalms, I have often indulged the liberty of a paraphrase, according to the words of Christ, or his apostles... Where the psalmist describes religion by the fear of God, I have often joined faith and love to it: Where he speaks of the pardon of sin, through the mercies of God, I have added the blood and merits of a Saviour... When he attends the ark with shouting into Zion, I sing the ascension of my Saviour into heaven, or his presence in his church on earth... ${ }^{29}$

\footnotetext{
${ }^{27}$ Ibid., 'Hymns', Volume 4, 147.

${ }^{28}$ Benson, English Hymn, 110.

${ }^{29}$ Watts, Works, 'Psalms', Volume 4, xvi-xvii.
} 
Watts states that his grand design was to make David 'speak as a Christian. ${ }^{30} \mathrm{We}$ should note that this hermeneutical approach was common in the commentaries of the day. ${ }^{31}$ It is therefore unfair to say, as Watson does, that Watts 'uses the psalms' and 'rather than following them, he makes them follow him. ${ }^{32}$ Similarly, although Achinstein is right to observe changes in political implications in Watts' hymns compared to those of the seventeenth century, it is wrong to say that his approach involved a 'rejection of typological thinking., ${ }^{33}$ Rather Watts is following where he believes the typology of the whole canon of scripture takes the psalms. These interpretative moves are more fully explained in Watts' later works on biblical theology where typology and fulfilment of biblical themes are explored. ${ }^{34}$ So Davie is correct in saying that Watts, "in no sense "freely adapted", but modernized according to a very strict method. ${ }^{35}$

Watts' innovation then was not in a novel hermeneutic but rather in bringing a traditional hermeneutic to bear in the singing of psalms. In this he had some predecessors but as Manning says, 'no one had so thoroughly carried out the plan before. $^{36}$

\footnotetext{
${ }^{30}$ Ibid., 'Psalms', Volume 4, xvii-xviii. Also see Robin A. Leaver, "Isaac Watts's Hermeneutical Principles and the Decline of English Metrical Psalmody," Churchman 92, no. 1 (1978).

${ }^{31}$ See for example Matthew Henry, Commentary on the Whole Bible (Peabody, Mass.: Hendickson Publishers, 2008). On the psalms in worship see S. E. Gillingham, Psalms through the Centuries, Blackwell Bible commentaries (Oxford: Blackwell 2008).

${ }^{32}$ Watson, English Hymn, 155.

${ }^{33}$ Achinstein, Literature and Dissent, 239. On political themes in Watts' hymns see John M. Hull, "From Experiential Educator to Nationalist Theologian: The Hymns of Isaac Watts," Bulletin of the Hymn Society of Great Britain \& Ireland 19, no. 7 (2010).

${ }^{34}$ See especially Watts, Works, 'Harmony of Religions', Volume 2, 'The Holiness of Times, Places and People', Volume 2, and 'Scripture History', Volume 3. For Watts' interest in the psalms and their correct interpretation also see Stephenson, "Dissenting Ministry," 270-75.

${ }^{35}$ Davie, Gathered Church, 23. For a specific analysis of Watts' method of interpretation see Bruce Andrew Chan, "Isaac Watts's Psalms of David Imitated in the Language of the New Testament" (University of London, 1968).

${ }^{36}$ Manning, Wesley and Watts, 81.
} 
In both hymns and psalms Watts argued for the need to express the experience of the Christian rather than the Jewish believer. He writes:

There is almost an infinite number of different occasions for praise and thanksgivings, as well as for prayer, in the life of a christian and there is not a set of Psalms already prepared that can answer all the varieties of the providence and the grace of God. ${ }^{37}$

Wright says that 'the extraordinary helpfulness of Watts's hymns is attributable chiefly to the fact that they are a faithful record of soul experience. ${ }^{38}$ As we will see below this focus on the experience of the Christian is key for Watts and connects to his understanding of the passions. Watts was equally concerned that praise focussed on Jesus and critiqued psalm singing for staying the shadows of Judaism when the daylight of the gospel had dawned. Gillman summarises: 'He clearly saw that the worship-song of the Christian Church must centre in Christ if it was to possess life and power. ${ }^{39}$

Watts wrote hymns on a great variety of themes; he says himself he tried to keep to the main themes of the orthodox faith and to avoid the emphases of particular groups. So he hoped to provide a hymn book that could be used across denominations. ${ }^{40}$ Escott provides a summary of Watts' themes ${ }^{41}$, and Watson explores some of these more fully. ${ }^{42}$

We should note that while it is only mentioned briefly Watts does also point to the role of the Holy Spirit in praise. He says that while there is no promise in Scripture for aiding hymns writers and congregations:

\footnotetext{
${ }^{37}$ Watts, Works, 'Psalmody', Volume 4, 284.

${ }^{38}$ Wright, Watts, 88.

${ }^{39}$ Gillman, English Hymn, 199.

${ }^{40}$ Watts, Works, 'Hymns', Volume 4, 148-49.

${ }^{41}$ Escott, Hymnographer, 183-89. Also see Albert Edward Bailey, The Gospel in Hymns: Backgrounds and Interpretations (New York: Charles Scribner's Sons, 1950).

${ }^{42}$ Watson, "Hymns of Watts."
} 
... yet Ministers that are fitted for such Performances may pray and hope for Divine Assistance in them all, and trust in the general Promises for Help in particular Services. ${ }^{43}$

Escott summarises Watts' argument: 'the ordinary assistance of the Holy Spirit is invoked in the duties of preaching and praying, why not then in the other part of public worship, the composing and singing of hymns. ${ }^{44}$

\subsection{Reason in praise}

As we will see below Watts' view of passion is the primary driving force for his theology of praise and the subsequent renovation of hymnody. However there are still a number of significant ways that his view of reason affects his approach to praise. The primary way we see this is in a simple but key aspect: the comprehension of the worshipper. Watts believes that worshippers must 'obey the direction of the word of God, and sing his praises with understanding. ${ }^{45}$ This requirement results in Watts expending a great deal of effort in facilitating the comprehension of the worshipper.

First is the content of what is sung: Watts says that he has steered clear of the more obscure and controversial parts of the Christian faith specifically to aid comprehension. Secondly he has avoided more exalted turns of phrase and sunk his metaphors to the level of 'vulgar capacities'. Thirdly, because of the system of 'lining out' a hymn, he has 'seldom permitted a stop in the middle of a line, and seldom left the end of a line without one', to aid comprehension. ${ }^{46}$ Fourthly, he renders the content of the psalms in the light of the gospel so that we may not sing in 'darkness' or 'without thought or meaning. ${ }^{47}$ Lastly he focuses each hymn on a single coherent theme: within the psalms this often meant dividing the psalm into sections with a hymn for each, or, in the case of

\footnotetext{
${ }^{43}$ Watts, Works, 'Psalmody', Volume 4, 288.

${ }^{44}$ Escott, Hymnographer, 129.

${ }^{45}$ Watts, Works, 'Hymns', Volume 4, 148.

${ }^{46}$ Ibid., 'Hymns', Volume 4, 149.

${ }^{47}$ Ibid., 'Psalms', Volume 4, xvi. Hoyles locates Watts' method here within the wider context of enlightenment thought in its consistent imagery of 'light'; Hoyles, Waning of the Renaissance, 162.
} 
longer psalms, writing hymns based on certain themes within it. ${ }^{48}$ All this is to serve the understanding of the worshipper.

Within this list Watts' use of language is worth particular attention. Watts says:

I have aim'd at ease of numbers and smoothness of sound, and endeavoured to make the sense plain and obvious. If the verse appears so gentle and flowing as to incur the censure of feebleness, I may honestly affirm, that sometimes it cost me labour to make it so: some of the beauties of poesy are neglected, and some wilfully defac'd; I have thrown out the lines that were too sonorous, and have given an allay to the verse, lest a more exalted turn of thought or language should darken or disturb the devotion of the weakest souls. $^{49}$

Similarly in his Psalms Watts says that he knows his verse will be below the esteem of critics, 'because I would neither indulge any bold metaphors, nor admit of hard words, nor tempt an ignorant worshipper to sing without his understanding., 50

Montgomery shows how Watts aims specifically at effective communication rather than artistic brilliance. Hence he utilises what Escott calls 'artistic kenosis', emptying himself of literary finery for the sake of understanding. ${ }^{51}$ Watts speaks of his aim to 'sink every line to the level of a whole congregation' ${ }^{, 52}$; so Davie writes:

This was a poet who, if he practised what Pope and the Scriblerus Club called 'the art of sinking', did so deliberately, after counting the cost, his eyes open to the risk he was running. ${ }^{53}$

Davie argues that revisions of hymns by Watts are driven, at least in part, by his desire for clarity which closes off 'loopholes' of meaning ${ }^{54}$, and Hoyles points to further

\footnotetext{
${ }^{48}$ See for example eighteen hymns on different themes within Psalm 119.

${ }^{49}$ Watts, Works, 'Hymns', Volume 4, 149.

${ }^{50}$ Ibid., 'Psalms', Volume 4, xx.

${ }^{51}$ Escott, Hymnographer, 26. David J. Montgomery, "Isaac Watts and Artistic Kenosis: The Rationale Behind the Work of Britain's Pioneer Hymnwriter," Scottish Bulletin of Evangelical Theology 5 (1987).

${ }^{52}$ Watts, Works, 'Psalmody', Volume 4, 291.

${ }^{53}$ Davie, Gathered Church, 24. See also Hoyles, Waning of the Renaissance, Chapter 18.
} 
efforts in 'sinking' language to aid comprehension. ${ }^{55}$ There is a connection here with the views on clarity in language developed by the Royal Society which we have already mentioned. We should also note the similarity with Watts' focus on clarity in preaching. ${ }^{56}$ Rogal comments on how this point is also true for his songs written for children. Watts, says Rogal, adapted his poetical technique and 'wrote to and for children, not about them. ${ }^{, 57}$

A second way in which Watts' view of reason is expressed in his hymns is in his scope of learning. Watson argues that Watts' natural philosophy and view of education shows itself in his hymn writing. ${ }^{58}$ Watts encourages the 'enlargement' of the mind by studying natural philosophy, travel, discussion, etc, so that students will 'furnish yourselves with a rich variety of ideas. ${ }^{, 59}$ This expansion of thought and rich knowledge is exactly what Watts says is needed in writing hymns to enable appropriate diction and breadth of expression. ${ }^{60}$ Manning suggests that this is what gives Watts a cosmic outlook; he says:

There is a sense of the spaciousness of nature, of the vastness of time, of the dreadfulness of eternity, in Watts which is missing or less felt in Wesley.... It is an echo of his encyclopaedic philosophical thought. ${ }^{61}$

Thirdly we see Watts' view of reason revealing itself in his hymns in their precision of thought and logical flow. We saw how Watts had followed Locke in his view of clear and distinct ideas, as opposed to words without ideas (although we noted some caveats on this). We remind ourselves that for Watts:

\footnotetext{
${ }^{54}$ Davie and Stevenson, English Hymnology, 12.

${ }^{55}$ Hoyles, Waning of the Renaissance, 245-50.

${ }^{56}$ See chapter 4 , section 2.3 .

${ }^{57}$ Samuel J. Rogal, "Watts' Divine and Moral Songs for Children and the Rhetoric of Religious Instruction," Historical Magazine of the Protestant Episcopal Church 40, no. 1 (1971): 100.

${ }^{58}$ Watson, English Hymn, 134-35.

${ }^{59}$ Watts, Works, 'Logic', Volume 5, 36.

${ }^{60}$ Watson, English Hymn, 138. See Watts, Works, 'Psalms', Volume 4, xxi.

${ }^{61}$ Manning, Wesley and Watts, 83.
} 
A clear and distinct idea is that which represents the object to the mind with full evidence and strength, and plainly distinguishes it from all other objects whatsoever. $^{62}$

Watson argues that Watts' hymns then express this in practice, 'because they often show this process of clarification, of the removal of obscure and confused ideas. ${ }^{63}$ This links to Watts' strong visual imagery which presents truth in great clarity and boldness. Here is one example:

There is a land of pure delight, Where saints immortal reign; Infinite day excludes the night, And pleasures banish pain.

There everlasting spring abides, And never-with'ring flow'rs:

Death, like a narrow sea, divides

This heav'nly land from ours. ${ }^{64}$

Watson also shows that Watts' view of logic is seen in the structure of his hymns and the way in which they deal with topics in appropriate order and distinguish between generals and particulars. While Watts' educational works were later in life than the majority of his hymn writing, Watson argues that there is a close affinity between the two. He also cites examples of Watts' grammatical and philological expertise showing themselves in his hymns. ${ }^{65}$

Lastly, and importantly we note how Watts' view of the relationship between reason and passion informs his hymn writing. We have previously seen how Watts believed reason was to find the truth but should be accompanied by appropriate passion. In addition, passion should be raised by contemplation of truth by our reason.

\footnotetext{
${ }^{62}$ Watts, Works, 'Logic', Volume 5, 21.

${ }^{63}$ Watson, English Hymn, 138.

${ }^{64}$ Watts, Works, 'Hymns', Volume 4, 222. On Watts technique in this hymn see Marini, "Hymnody as History," 300.

${ }^{65}$ Watson, English Hymn, 139-44.
} 
This view leads to a balance between the objective and subjective in Watts' hymns. We will see the strong focus on subjective response below; however this always flows from objective truth. So in discussion of Watts' communion hymns Routley says that in the best examples they are marked by a 'firm and controlled objectivity'; but that they lead the worshipper to an 'ecstatic, almost inarticulate adoration. ${ }^{66}$ Similarly Watson says:

It is the balance between the personal and doctrinal that is so effective in these hymns. The personal gives them authenticity, the authenticity of experience; the doctrinal roots them firmly in established patterns of sin, penitence, and redemption. ${ }^{67}$

Watts' communion hymns provide particularly good examples of this. The hymn, 'Communion with Christ, and with saints', begins with this stanza:

Jesus invites his saints

To meet around his board;

Here pardon'd rebels sit and hold

Communion with their Lord.

The invitational words of Jesus in Scripture are presented to the worshipper with the reminder of their status as pardoned rebels. The hymn continues with a description of Jesus' body and blood nourishing believers, moves to the unity of the body of Christ, and finishes with the cry:

Let all our power be join'd,

His glorious name to raise;

Pleasure and love fill ev'ry mind,

And ev'ry voice be praise. ${ }^{68}$

So the truth that the act of communion represents is first presented in clear and distinct ideas and then the passionate response follows.

\footnotetext{
${ }^{66}$ Erik Routley, "Eucharistic Hymns of Isaac Watts," Worship 48, no. 9 (1974): 533-34.

${ }^{67}$ Watson, "Hymns of Watts," 58.

${ }^{68}$ Watts, Works, 'Hymns', Volume 4, 257-58.
} 
Other communion hymns tell the story of the cross, remind worshippers of the promises of God through the atonement, place the cross as the climactic centre point of history, and detail the objective realities achieved through it; but in each case appropriate subjective responses flow from these truths. ${ }^{69}$ So Marini says:

Watts gave classic expression to the Atonement as cosmic event and personal experience, capturing and transmitting with enormous power the objective and subjective dimensions of the evangelical economy of grace. ${ }^{70}$

So we see that in a variety of ways Watts' view of the role of reason itself and its relation to passion played out in his hymns.

\subsection{Passion in praise}

Watts views praise as the moment in which the worshipper speaks to God from the heart. Watson demonstrates that in this Watts is combining two traditions into one: that of the metrical psalm which states Scriptural truth, and that of the religious poem which expressed the believer's experience. ${ }^{71}$ This combination is key for Watts: his renovation is at root a desire to allow the Scriptural truth of the gospel to be linked with the personal experience of the worshipper. Lying behind this is Watts' theology of the passions.

Personal experience of God forms a key part of Watts' understanding of praise. For example:

The first and chief intent of this part of worship, is to express unto God what sense and apprehensions we have of his essential glories; and what notice we take of his works of wisdom and power, vengeance and mercy; it is to vent the inward devotion of our spirits in words of melody, to speak our own experience of divine things, especially our religious joy. ${ }^{72}$

\footnotetext{
${ }^{69}$ On the classic example of 'When I survey the wondrous cross' see Watson, English Hymn, 160-70.

${ }^{70}$ Marini, "Hymnody as History," 289.

${ }^{71}$ Watson, English Hymn, 133.

${ }^{72}$ Watts, Works, 'Psalmody', Volume 4, 282.
} 
We see this again in Watts' differentiation of singing from the reading of Scripture:

By reading we are instructed what have been the dealings of God with men in all ages ... but songs are generally expressions of our own experiences, or of his glories; we acquaint him what sense we have of his greatness and goodness, and that chiefly in those instances which have some relation to us: we breath out our souls towards him, and make addresses of praise and acknowledgment to him. $^{73}$

Escott says that this is the most important statement in Watts' essay and shows his philosophy of worship, that, "Singing is the response of the redeemed community., More than anything else this focus on the believers' heart response to God in praise is what lies behind Watts' desire to reform the content of hymns. He explains that in singing only psalms the heartfelt devotion of the worshipper is stopped or muted:

Hence it comes to pass, that when spiritual affections are excited within us, and our souls are raised a little above this earth in the beginning of a psalm, we are checked on a sudden in our ascent toward heaven by some expressions that are more suited to the days of carnal ordinances, and fit only to be sung in the worldly sanctuary. When we are just entring into an evangelic frame by some of the glories of the gospel presented in the brightest figures of Judaism, yet the very next line perhaps which the clerk parcels out unto us, hath something in it so extremely Jewish and cloudy, that darkens our sight of God the saviour: Thus by keeping too close to David in the house of God, the vail of Moses is thrown over our hearts. ${ }^{75}$

Watts' reference to the veil of Moses over our hearts is drawn from the apostle Paul's comment on the veil of understanding. ${ }^{76}$ However Watts' concern is that drawing such a veil over the gospel does not allow appropriate passionate expression in praise: our 'spiritual affections' are 'checked'. So Escott says:

\footnotetext{
${ }^{73}$ Ibid., 'Psalmody', Volume 4, 277.

${ }^{74}$ Escott, Hymnographer, 122.

${ }^{75}$ Watts, Works, 'Hymns', Volume 4, 147.

${ }^{76}$ See 2 Corinthians, Chapter 3.
} 
Watts was really the first hymn-writer to give due place to the subjective aspect of worship-song, and to take into full consideration the psychology of the congregation in its praises. ${ }^{77}$

It is worth seeing this emphasis in Watts' thought by examining some further statements. For example he says that if we sing only the words of David, 'our affections want something of property or interest in the words, to awaken them at first, and to keep them lively. ${ }^{78}$ Watts says his desire is to 'remove this great inconvenience' and so to 'introduce warm devotion into this part of divine worship. ${ }^{, 79}$

Elsewhere Watts says that when we can express our own hearts there is 'divine delight' in our praise, but when we are forced to speak only the heart of David 'our own hearts are as it were forbid the pursuit of the song. ${ }^{80}$ In being limited to a literal rendering of the psalms Watts says the Christian worshipper may know moments of heart expression but before long the words cease to express their experience and the result is that their souls are 'discomposed', the 'strings of harmony are untuned', and they can only sing with 'cold devotion'. ${ }^{81}$ Watts ties this directly to his view of singing:

Let us remember, that the very power of singing was given to human nature chiefly for this purpose, that our own warmest affections of soul might break out into natural or divine melody, and that the tongue of the worshipper might express his own heart. ${ }^{82}$

So Watts' central argument for renovation is an argument from the expression of passion. In providing lyrics that reflect the experience of the Christian believer, Watts is solving this problem. He says of the content of his hymns:

The most frequent tempers and changes of our spirit, and conditions of our life are here copied, and the breathings of our piety expressed according to

\footnotetext{
${ }^{77}$ Escott, Hymnographer, 114.

${ }^{78}$ Watts, Works, 'Psalms', Volume 4, xi.

${ }^{79}$ Ibid., 'Psalms', Volume 4, xi.

${ }^{80}$ Ibid., 'Hymns', Volume 4, 148.

${ }^{81}$ Ibid., 'Psalms', Volume 4, xv-xvi.

${ }^{82}$ Ibid., 'Psalms', Volume 4, xiv.
} 
the variety of our passions; our love, our fear, our hope, our desire, our sorrow, our wonder and our joy. ${ }^{83}$

This forms a key part of his argument for the writing of new hymns as the particular experiences of the believer should be expressed. Watts critiques the use of hymns stating general truths saying:

It is a more dull, and obscure, and unaffecting method of worship to preach, or pray, or praise always in generals: It doth not reach the heart, nor touch the passions... ${ }^{84}$

The ideal for Watts is that the worshipper can speak specifically of his or her own experience of God, and that this is ideal because of the effect on their passions. He says:

This keeps all the springs of pious passion awake, when every line and syllable so nearly affects himself; this naturally raises, in a devout mind, a more lively and transporting worship. ${ }^{85}$

Watts pushes this point in responding to the anticipated objection that he is presuming that he can write better hymns than the Spirit. He acknowledges that no human could write better songs, prayers or sermons than there are in Scripture for the purpose for which they were written. However he goes on:

...a song, a sermon, or a prayer that expresses my wants, my duties or my mercies, though it be composed by a human gift, is much better for me than to ty myself to any inspired words in any part of worship which do not reach my case; and consequently can never be proper to assist the exercise of my graces or raise my devotion. ${ }^{86}$

Hence for Watts Christian praise is a primary place for the exercise and expression of Christian passion and his hymns are to lead worshippers into this. Orchard says that 'It

\footnotetext{
${ }^{83}$ Ibid., 'Hymns', Volume 4, 148.

${ }^{84}$ Ibid., 'Psalmody', Volume 4, 284.

${ }^{85}$ Ibid., 'Psalms', Volume 4, xi.

${ }^{86}$ Ibid., 'Psalmody', Volume 4, 287.
} 
is this opening of Scripture to a devotional response which earns Watts his place in the pantheon of great hymn writers. ${ }^{87}$

The worshipper therefore should also be stimulated by the content of what is being sung. This links to our observations on excitation of passion by meditation. ${ }^{88}$ Watts had commended meditation in acts of personal reflection, but the same dynamic is at work in praise. Acts of praise involve 'kindling into divine love by the meditations of the loving kindness of God, and the multitude of his tender mercies. ${ }^{89}$ In this regard Watts comments on the wisdom of God in commanding singing:

How happily suited is this ordinance to give a loose to the devout soul in it's pious and cheerful affections? What a variety of sanctified desires, and hopes and joys, may exert themselves in this religious practice, may kindle the souls of christians into holy fervour, may raise them near to gates of heaven, and the harmony of the blessed inhabitants there ${ }^{90}$

This links with Watts' dramatic portrayal of Christian truth, most commonly the cross. As the worshipper meditates on such truth the appropriate passionate response is elicited. For example a hymn describing Christ dying because of our sins ends like this:

Whilst with a melting, broken heart,

My murder'd Lord I view,

I'll raise revenge against my sins,

And slay the murd'rers too. ${ }^{91}$

So praise allows both expression and stimulation of passion towards God. We can then see this guiding of worshippers in their passionate response in Watts' lyrics. These regularly speak of warmed hearts, melting eyes, and transporting joys. In putting such words on the lips of those singing Watts is both allowing their passionate expression

\footnotetext{
${ }^{87}$ Stephen Orchard, "The Hymns of Isaac Watts," Journal of the United Reformed Church History Society 6, no. 3 (1998): 157.

${ }^{88}$ See chapter 3 section 5.3 .

${ }^{89}$ Watts, Works, 'Hymns', Volume 4. 147.

${ }^{90}$ Ibid., 'Love of God', Volume 2, 679.

${ }^{91}$ Ibid., 'Hymns', Volume 4. 236.
} 
and instructing them as to how they should feel. So Marshall and Todd say: 'He took the singers and their feelings by the hand and led them along an instructive pathway., ${ }^{92}$

It is worth observing some examples of this leading of worshippers in appropriate passions. Five stanzas follow which illustrate how Watts' lyrics tell singers what they should feel, or the manner in which they should sing:

'Twere you that pull'd the vengeance down Upon his guiltless head:

Break, break, my heart! O burst mine eyes!

And let my sorrows bleed. ${ }^{93}$

Such wond'rous love awakes the lip Of saints that were almost asleep, To speak the praises of thy name, And makes our cold affections flame. ${ }^{94}$

My heart grows warm with holy fire, And kindles with a pure desire: Come, my dear Jesus, from above, And feed my soul with heav'nly love. ${ }^{95}$

Now shall my inward joys arise, And burst into a song; Almighty love inspires my heart, And pleasure tunes my tongue. ${ }^{96}$

O! what immortal joys I felt, And raptures all divine, When Jesus told me, I was his, And my Beloved mine! ${ }^{97}$

\footnotetext{
${ }^{92}$ Marshall and Todd, Congregational Hymns, 33.

${ }^{93}$ Watts, Works, 'Hymns', Volume 4, 233.

${ }^{94}$ Ibid., 'Hymns', Volume 4, 174.

95 Ibid., 'Hymns', Volume 4, 204.

${ }^{96}$ Ibid., 'Hymns', Volume 4, 161.

${ }^{97}$ Ibid., 'Hymns', Volume 4, 225.
} 
The effect Watts desired is illustrated in a letter from Philip Doddridge. He writes to Watts describing an occasion singing one of Watts' hymns and says:

... and in that part of the worship I had the satisfaction to observe tears in the eyes of several of the auditory, and after the service was over some of them told me that they were not able to sing, so deeply were their minds affected with it... ${ }^{98}$

Doddridge presumably knows that Watts would have approved of such a reaction.

In this view of heartfelt, responsive praise to God Watts sees praise as the nearest the church gets to the heavenly state:

While we sing the Praises of our God in his Church, we are employed in that part of Worship which of all others is the nearest a-kin to Heaven... ${ }^{99}$

Praise is the sweetest part of divine worship; it is a short heaven here on earth. ${ }^{100}$

In its highest form, for Watts, praise was an anticipation of the joy of heaven, a time when he saw our passions to be finally purified and perfectly employed in the expression of love for God and joy in his goodness and presence.

Marshall and Todd have pointed to a supposed contradiction in this aim of Watts in his hymn writing. They argue that his focus on arousing the passions presupposes that individuals are 'intrinsically capable of virtue or piety', but that this positive assumption conflicts with his position on the sinfulness of humanity. They say:

This ameliorability [of the passions] is apparently at odds with the conviction of the worm-like baseness of humankind. The depravity of humanity, an item of Watts's faith, is evidently incompatible with his poetic intent and method. ${ }^{101}$

\footnotetext{
${ }^{98}$ Watts, Posthumous Works, Volume 2, 26-27.

${ }^{99}$ Watts, Works, 'Hymns', Volume 4, 147.

${ }^{100}$ Ibid., 'Remnants', Volume 4, 628.

${ }^{101}$ Marshall and Todd, Congregational Hymns, 33.
} 
However the answer to this apparent contradiction lies in our previous analysis of Watts' doctrine of the passions. He does indeed believe in the depravity of humanity and the resulting corruption of their passions; we saw that it is in precisely this way that he stands apart from the sentimental moralists of his day. ${ }^{102}$ However as we have seen, Watts believed that in conversion the faculties of the soul are corrected and the passions are renewed.

So it is true to say that he presumed on the capability of individuals to express godly passions, and writes his hymns to elicit and direct them. But it is not true that he thinks this ability is 'intrinsic'; rather he thinks it is a gift of grace by the work of the Spirit and so such a dynamic is only possible for the Christian believer.

We have seen then how Watts' hymns were driven by a desire for the personal expression and excitation of the passions of the worshipper. This devotional element has been clearly noted in the literature but it has not been linked back to Watts' overall theology of the passions from which it originates.

We now move to consider wider areas of Watts' view on the passions influencing his view of praise. Firstly Watts' view of passion in praise relates to his understanding of the power of poetry as well as the affective qualities of music. ${ }^{103}$ In the preface to Horae Lyricae Watts refers to the effects poetry can have in awakening pious passions. $\mathrm{He}$ goes on to speak of the differences and advantages of specifically Christian poetry over against classical mythology concluding:

And if we survey the one as themes divinely true, and the other as a medley of fooleries which we can never believe, the advantage for touching the springs of passion will fall infinitely on the side of the christian poet; our wonder and our love, our pity, delight and sorrow, with the long train of hopes and fears, must needs be under the command of an harmonious pen,

\footnotetext{
${ }^{102}$ Marshall and Todd fail to discriminate in this way between Watts and sentimental moralists such as Shaftesbury. See ibid., 31.

${ }^{103}$ On Watts' poetry see Hoyles, Waning of the Renaissance, Chapters 15-18.
} 
whose every line makes a part of the reader's faith, and is the very life or death of his soul. ${ }^{104}$

Hence the powerful and affective nature of poetry should be employed by the Christian poet both to arouse and allow expression of the godly passions of the believer. ${ }^{105}$ Marshall and Todd helpfully describe Watts' use of strong visual imagery and in doing so, 'making visible and immediate what through time or distance or distraction may have become obscured.' The result is that 'the passions are rehearsed in response to affecting scenes.' 106

However Marshall and Todd again set Watts' confidence in the power of poetry to achieve this against his view of humanity: 'Watts's faith in the evangelical power of stirring poetry supersedes his own distrust of the world of sinful flesh and the tempting Fancy. Poetry wins., 107

As above this does not appreciate the theological substructure to Watts' approach to poetry and hence praise. Watts only had confidence in the helpfulness of poetry for the heart to which the Spirit had given new affections and in which he was active. He did not believe, as Marshall and Todd state, that 'humankind was salvable by means of a poetic appeal to the passions. ${ }^{108}$

Secondly we see Watts' view of the passions affecting his writing of hymns. We noted above how he 'sunk' his language to aid understanding; now we see that he also speaks of having to restrain his language to allow appropriate expression of passion. Speaking of his second book of hymns where he allowed himself a freer style he says:

\footnotetext{
${ }^{104}$ Watts, Works, 'Horae Lyricae', Volume 4, 322-23.

${ }^{105}$ For a discussion of some of Watts' poetical techniques see Manning, Wesley and Watts, 91-98.

${ }^{106}$ Marshall and Todd, Congregational Hymns, 56.

107 Ibid., 56.

${ }^{108}$ Ibid., 58. While making many insightful observations, Marshall and Todd also fail to give full appreciation to the Biblical language Watts employs resulting in their making overstatements as to his use of violent, ascetic and erotic language. Ibid., 44-56.
} 
I confess my self to have been too often tempted away from the more spiritual designs I proposed, by some gay and flowery expressions that gratified the fancy; the bright images too often prevailed above the fire of divine affection; and the light exceeded the heat. ${ }^{109}$

Hence Watts is concerned that poetic imagery does not become so grand and exalted as to leave the heart of the believer behind.

We also see a desire to write 'from the heart' and so communicate to the heart. Watts says:

If the heart were first inflamed from heaven, and the muse were not left alone to form the devotion, and pursue a cold scent, but only called in as an assistant to the worship, then the song would end when the inspiration ceases; the whole composure would be of a piece, all meridian light and meridian fervour; and the same pious flame would be propagated, and kept glowing in the heart of him that reads. ${ }^{110}$

While written of poetry, here is a good summary of Watts' ideal hymn: high points of light and fervour, coming from the warmed heart of the writer, and resulting in the same in the singer. We note the similarity that we observed in preaching of the warmed heart of the minister resulting in the warmed heart of his listeners. ${ }^{11}$

We finish this section by observing that Watts always thought the work of the Spirit was specifically required if his great aim of passionate expression in praise was to be achieved. This flows from what we previously noted in his doctrine of the passions: that the work of the Spirit is always required for godly affections. For example a hymn entitled 'Breathing after the holy Spirit; or Fervency of Devotion desired', speaks of the emptiness of passionless praise:

In vain we tune our formal songs, In vain we strive to rise;

\footnotetext{
${ }^{109}$ Watts, Works, 'Hymns', Volume 4, 150.

${ }^{110}$ Ibid., 'Horae Lyricae', Volume 4, 323.

${ }^{111}$ See chapter 4 , section 2.4
} 
Hosannas languish on our tongues,

And our devotion dies.

It proceeds to intercede for the work of the Spirit to transform this state:

Come Holy Spirit, heav'nly Dove,

With all thy quick'ning powers;

Come, shed abroad a Saviour's love,

And that shall kindle ours. ${ }^{112}$

Hence the Spirit kindles our love for God by making us aware of God's saving love for us and so enables us to sing praise.

\section{Summary and comparison}

We have seen that Watts' view of reason and passion, and their relation to each other is foundational to his theology of praise and his subsequent aims for and method of writing of hymns. The expression of passion is the primary motivation behind his arguments for writing new hymns and paraphrasing the psalms. However reason is always operative as a foundation to such passion, and Watts' triumph in hymnody is, at least in part, because of his judicious combination of these. Watson summarises:

'Watts's particular genius lies in combining the clarity of rhetorician with the force and energy of the kind of religious emotion which is found in Horae Lyricae. ${ }^{113}$ Similarly Wright sees Watts' genius lying in his combination of objective truth and subjective expression: 'He was objective without being abstract, and subjective without being sentimental. ${ }^{114}$

It is often pointed out that Watts' hymns acted as common liturgy in dissenting churches and so prevented many from drifting into heterodoxy, especially on the topic of the

\footnotetext{
${ }^{112}$ Watts, Works, 'Hymns', Volume 4, 211.

${ }^{113}$ Watson, English Hymn, 149.

${ }^{114}$ Clifford J. Wright, "Isaac Watts: The Man, his Mind and Message," Modern Churchman 38, no. 4 (1948): 351 .
} 
Trinity. ${ }^{115}$ This may well be the case but it is worth noting that Watts himself does not see teaching, or defending truth as his primary aim in writing hymns. At one point he does say, 'instruction is allow' $\mathrm{d}$ to be one end of psalmody. ${ }^{, 16}$ But this is in admitting that people can learn from contemplation of a psalm, it is not used an argument for his renovation of praise. It is the expression of passion, not the defence of truth, that was the driving force behind Watts' hymn writing.

Watts' aim is not only to argue for his renovations in what is sung. He also wishes to defend the Christian worshipper from accusations of enthusiasm and to reassure them that there is warrant 'for pious souls to indulge their most lively affections in worship, and that without any abuse of their reason, or abasement of their religion. ${ }^{, 17}$ In this his purpose in praise is tied to his aim in writing on the passions where he wished to 'to vindicate the affectionate Christian from the unjust reproaches of men, in his warmest exercises of love to God and devotion., 118

Watts' renovation of praise finds its place within his broader desire to reform and revive the church. His hope in writing and publishing his hymns was nothing less than to bring a 'returning glory to the churches. ${ }^{119}$ But he believed this would be achieved by being 'a helper to the joy of the meanest christian., 120

This approach of Watts is seen more sharply when he is compared to those around him. As we have mentioned above Watts was not alone in seeking a reformation of praise in the early eighteenth century. The previously mentioned series of sermons at Eastcheap was to that end. Escott speaks of the authors as a group who share some of Watts' ideals; he also hypothesises about the influence of Watts' work on these discourses

\footnotetext{
${ }^{115}$ Michael A. G. Haykin, "The Undivided Three: The Doctrine of the Trinity in Church History," Reformation \& Revival 10, no. 3 (2001): 61-64. Manning, Wesley and Watts, 136-37. Davies, Worship and Theology, Vol 3, 94.

${ }^{116}$ Watts, Works, 'Psalms', Volume 4, xv.

${ }^{117}$ Ibid., 'Love of God', Volume 2, 696.

${ }^{118}$ Ibid., 'Love of God', Volume 2, 696.

${ }^{119}$ Ibid., 'Psalmody', Volume 4, 281.

${ }^{120}$ Ibid., 'Psalms', Volume 4, xxi.
} 
saying, 'sometimes their words are merely echoes of Watts' Preface and Short Essay. ${ }^{121}$

Certainly there is overlap in the view of praise put forward, although compared to the sermons as a whole Watts presents a much more positive view of the way singing can aid worshippers in their passions, rather than simply insisting on the need for correct heart in singing. For example Earle speaks of the need to sing with understanding and love for God. However in speaking of the purpose of singing he focuses on the aspect of 'mutual edification'. 122

Other sermons do express the aim of exciting passion. Mr Harris for example writes:

'Tis an Affecting Exercise, peculiarly fitted with special Advantage to raise holy Affections of Soul, and enliven every Grace.... And the same thing will more powerfully move and more sensibly affect, when 'tis devoutly sung, than when 'tis ever so carefully read. ${ }^{123}$

However this is as far as the writers go, whereas Watts explores this area far more fully.

The preachers of this series overall agree with Watts on not being limited to singing the psalms; however they are content to continue to do so, admitting that at times the words do not reflect the experience of the worshipper. On such occasions they say the activity has the aim of instruction more than expression of praise. ${ }^{124}$ In addition they say that newly composed hymns should 'be collected from the Holy Scriptures', with a 'diligent regard' for the text and sense, the belief being that the Scriptures 'appear best in their own naked Simplicity. ${ }^{125}$ By comparison Watts' desire to express the experience and

\footnotetext{
${ }^{121}$ Escott, Hymnographer, 110. Escott says there can be little doubt that they had read Watts' Preface and Essay; in actual fact the Essay is specifically commended by one of the contributors, so that little doubt is removed, Discourses of Singing, 154.

${ }^{122}$ Discourses of Singing, 5-14.

${ }^{123}$ Ibid., 74-75.

${ }^{124}$ Ibid., 119.

${ }^{125}$ Ibid., 117.
} 
hence passions of the believer meant that he both transformed the psalms and sat looser to the text of Scripture in writing hymns.

The Church of England minister Theophilus Dorrington also points to the role of passion in praise. Speaking of music, he says:

So it does in its Nature tend and serve, to raise and excite, and improve our Affection, and concern of Mind about the Divine Matters which come under our Consideration in our Worship, and to heighten our Devotion in our Worship. ${ }^{126}$

Dorrington also partly justifies the use of instrumentation on the basis that it can 'assist and promote our devout Affections. ${ }^{127}$ Another example of a sermon from within conformity that gives a limited but significant place to our passions is by William Burscough. ${ }^{128}$ While the view of the experience of praise in these works is not as exalted as in Watts, the role of passion is clearly present.

There were other hymn writers within dissent however making the link between the writing of new hymns and the stimulation of the passions. For example Joseph Boyse ${ }^{129}$ argued that communion hymns were needed so as to:

...furnish us with the most genuine subject of our grateful acknowledgements to our God and Saviour, and such as most effectually tend to excite in us all those pious affections which become the Communicants at that holy Table. ${ }^{130}$

\footnotetext{
${ }^{126}$ Dorrington, Discourse on Singing, 53.

${ }^{127}$ Ibid., 239.

${ }^{128}$ William Burscough, The Duty of Praise and Thanksgiving (London: S. Crouch and T. Childe, 1715).

${ }^{129}$ English Presbyterian Minister (1660-1728)

${ }^{130}$ J. Boyse, Sacramental Hymms (Dublin: Thomas Parkhurst, 1693).
} 
Another example comes from the preface to a collection of hymns published in 1709 which refers to the power of poetry to 'paint agreeable pictures on the Imagination, to actuate the Spirits, and give the Passions a Noble Pitch. ${ }^{131}$

So other hymn writers aided the passionate expression of their congregations through the writing of new hymns, especially for communion and sometimes baptism, as well as on more general topics. ${ }^{132}$

Hence Watts was not unique in his view of praise and resulting hymn writing; rather he was within a small but significant group arguing for the reformation of the praise of the church. Watts however emerged as the most significant individual of that group primarily because of the excellence with which he performed his task. He also articulated his theology of praise and its connection with the passions more fully and worked through the implications more consistently. This is seen particularly in his work on the psalms to which we now turn.

Watts was not the first to paraphrase the psalms so that they were more suitable for Christian praise. ${ }^{133}$ However his view of praise meant he undertook this work with far greater comprehensiveness than his predecessors. As he himself says:

Though there are many gone before me, who have taught the Hebrew psalmist to speak English, yet I think I may assume this pleasure of being the first who hath brought down the royal author into the common affairs of the christian life, and led the psalmist of Israel into the church of Christ, without anything of a jew about him. ${ }^{134}$

\footnotetext{
${ }^{131}$ Dennis Dryden, A Collection of Divine Hymns and Poems on Several Occasions (London: J. Baker, 1709).

${ }^{132}$ For example Joseph Stennett, Hymns Compos'd for the Celebration of the Holy Ordinance of Baptism (John Marshall, 1695). Joseph Stennett, Hymns in Commemoration of the Sufferings of Our Blessed Saviour Jesus Christ Compos'd for the Celebration of His Holy Supper (London: J. Darby, 1697). Richard Davis, Hymns Composed on Several Subjects (London: W. Marshall and H. Bernard, 1694). Dryden, Hymns.

${ }^{133}$ Escott, Hymnographer, Chapter 3. Watson, English Hymn, Chapter 6.

${ }^{134}$ Watts, Works, 'Psalms', Volume 4, xxi.
} 
This is where Escott says Watts' originality lies. Those who supported the singing of new hymns thought that the psalter was incomplete by itself and required supplementation. Watts by comparison believed it was not only incomplete but inadequate as it stood. As Escott says, the issue is, 'The inadequacy of its content to express the truth of the Gospel and sound the whole gamut of the believer's emotions. ${ }^{135}$ So the root-and-branch reform which Watts undertook was driven by the prominent place he gave to the passions. Hence while there is a shared ethos over the expression of passion in praise with other writers, Watts follows through on the implications of this far further than anyone else.

We move now to compare Watts to his Puritan predecessors. We again can only illustrate some of the ways in which his modified view of reason and passion caused him to move from Puritan practice of praise. We must first note areas of continuity in the expression of passion in praise. While some Puritans were concerned about the legitimacy of singing at all many were very positive about it because of the effect on the passions. So Richard Baxter wrote:

For my self I confess that Harmony and Melody are the pleasure and elevation of my Soul, and have made a Psalm of Praise in the holy Assembly the chief delightful Exercise of my Religion and my Life. ${ }^{136}$

Baxter also speaks of the power of poetry saying, 'as it expresseth affections, so doth it raise them. ${ }^{137}$ Benjamin Keach too not only wrote hymns but argued about the place of passion in singing:

We must sing with Affections; let your joyful Noise be from the sense of God's Love in a dear Redeemer to your own Souls. Let it be by exciting

\footnotetext{
${ }^{135}$ Escott, Hymnographer, 113.

${ }^{136}$ Baxter, Poetical Fragments.

${ }^{137}$ Richard Baxter, Paraphrase on the Psalms of David (London: Thomas Parkhurst, 1692).
} 
your graces; let faith be in exercise in this Duty as well as in Prayer and under the Word. Let it be with inward Joy... ${ }^{138}$

Similarly William Barton quotes Justin Martyr on the 'use and excellency of spiritual songs':

It moves the minde, and makes affection strong,

To that which is so taking in the SONG. ${ }^{139}$

Watts then was continuing and developing one stream of Puritan thought. However there are also significant modifications. First Watts carries out his program of hymn writing far more radically than the majority of Puritans would have been happy with in moving away from strict paraphrases of the biblical text. As we have seen such a move is driven by his desire that the passions of the worshipper can be appropriately stimulated and expressed.

Watts' Enlightenment view of language also results in a greater focus on clarity of ideas in his hymns. As we saw with his view of preaching there is a simplifying effect which aims at greater comprehension by the singer. There is also greater confidence in the power of language to move the passions. This can be connected with Watts' move from a purely voluntaristic view of the passions which we explored in chapter 3 . This should not be overstated but is present. As we previously noted Puritan theology tended to see the passions as an exercise of the will; this then informed their view of the passions in praise. An example is Stephen Charnock's sermon on 'Spiritual Worship'. Having said that worship, including praise, is an act of the understanding, he goes on:

Tis also an act of the Will, whereby the Soul adores and reverenceth his Majesty, is ravisht with his amiableness, embraceth his goodness, enters it

\footnotetext{
${ }^{138}$ Benjamin Keach, The Breach Repaired in God's Worship, or, Singing of Psalms, Hymns, and Spiritual Songs, Proved to be an Holy Ordinance of Jesus Christ with an Answer to all Objections (London: John Hancock, 1691), 191-92.

${ }^{139}$ William Barton, A Century Of Select Hymns (London: Francis Eglesfield, and Thomas Underhill, 1659).
} 
self into an intimate Communion with this most lovely object, and pitcheth all his affections upon him. ${ }^{140}$

We see here strong elements of affective religion, but as an exercise of the will. Watts' move to a partially passive view of the affections means he does not speak of the worshipper choosing God in this way, but rather when presented with appropriately moving words, will experience such passions. There is therefore a subtle move towards the stimulation of the worshipper's passions by appropriate means.

However Charnock and others also emphasised the necessity of renewal by the Holy Spirit before any worship of God could be truly spiritual, and that all worship was done with the assistance of the Spirit. ${ }^{141}$ This is a Puritan theme Watts continued to stress.

Watts then renovated the praise of the church and this is the area he succeeded in above all others. This renovation was under-girded and indeed driven by his view of reason and passion in the Christian life. His hymn writing then finds its place within his great concern to revive the church of his day. He expresses his desire:

O may I live to see such psalmody performed in these evangelic beauties of holiness... Then my soul shall be all admiration, my tongue shall humbly attempt to mingle in the worship, and assist the harmony and the joy. ${ }^{142}$

\footnotetext{
${ }^{140}$ Stephen Charnock, Several Discourses Upon the Existence and Attributes of God (London: D. Newman, 1682), 141.

${ }^{141}$ Ibid., 141-43.

${ }^{142}$ Watts, Works, 'Psalmody', Volume 4, 281.
} 


\section{Chapter 6 The Method of Prayer}

\section{Introduction}

\subsection{Background}

The background to views of prayer in the eighteenth century lies in the debates over the Church of England prayer book during the preceding two centuries. ${ }^{1}$ There had been consistent Puritan pressure to reform the prayer book. There had also been protest from some against the imposition of set prayers within such a book. ${ }^{2}$ The choice, says Davies, was a simple one between 'set forms or spontaneity." 3

The Puritan arguments for reformation were driven by their desire to remodel all liturgy on the Bible. ${ }^{4}$ For prayer, however, this led to areas of debate, in particular whether the Lord's Prayer was a pattern to be followed or a set form to be repeated. ${ }^{5}$ Opinions on this and other issues resulted in three groups with differing positions on public prayer. Some within the national church wanted set prayers, separatists and more radical

\footnotetext{
${ }^{1}$ For an overview see Isaac Stephens, "Confessional Identity in Early Stuart England: The "Prayer Book Puritanism" of Elizabeth Isham " Journal of British Studies 50, no. 1 (2011); Kenneth Fincham and Nicholas Tyacke, Altars Restored: The Changing Face of English Religious Worship, 1547-c.1700 (Oxford: Oxford University Press, 2007); John E. Skoglund, "Free Prayer," Studia Liturgica 10, no. $3 / 4$ (1974); A. E. Peaston, The Prayer Book Tradition in the Free Churches (London: James Clarke \& Co., 1964). For Puritan and Separatist forms see James F. White, Protestant Worship: Traditions in Transition (Louisville, Ky.: Westminster/John Knox Press, 1989), Chapter 7.

${ }^{2}$ See the discussion by Ramie Targoff, Common Prayer: The Language of Public Devotion in Early Modern England (Chicago: University of Chicago Press, 2001), Chapter 2.

${ }^{3}$ Davies, Worship and Theology, Vol 2, 188-89.

${ }^{4}$ Iain H. Murray, "The Directory for Public Worship," in To Glorify and Enjoy God: A Commemoration of the 350th Anniversary of the Westminster Assembly, ed. John L. Carson and David W. Hall (Edinburgh: Banner of Truth Trust, 1994), 176-78.

${ }^{5}$ Horton Davies, The Worship of the English Puritans (Glasgow: Robert Maclehouse and Co., 1948), 99101.
} 
Puritans wanted complete freedom in prayer, and others within conformity were happy with a mix of both. ${ }^{6}$

While some opposed the use of certain set prayers because of the expressions they contained, many opposed them in principle. ${ }^{7}$ Davies outlines their concerns: set prayers robbed the congregation of the gift of prayer, were too impersonal, made the words of the prayer chosen too important, led to hypocrisy, and resulted in persecution. ${ }^{8}$ The reply from those in favour of set liturgy was that spontaneous prayer gave no thought to what was being said, resulted in ostentation in prayer, and gave the people listening no opportunity to evaluate what was being said. ${ }^{9}$

The Westminster Assembly produced the Directory of Public Worship in 1645 which specifically mentions the hindrance of set forms of prayer in the preface. ${ }^{10}$ Set prayers are avoided in the Directory but the suggested content of prayer was given in great detail. This content was introduced with the phrase, 'to call upon the Lord to this effect...', and the content was phrased in such a way that it could not simply be read by the minister. ${ }^{11}$ This end product is taken to be a compromise position between Congregationalists and Presbyterians. ${ }^{12}$

The result in Puritan prayer is described by Davies:

Such spontaneous prayer was characterized by assurance, simplicity, naturalness, intimacy, and a moving directness in the approach to God. Its

\footnotetext{
${ }^{6}$ Ibid., 98-99.

${ }^{7}$ See the discussion by Bryan D. Spinks, "The Origins of the Antipathy to Set Liturgical Forms in the Englsih-Speaking Reformed Tradition," in Christian Worship in Reformed Churches Past and Present, ed. Lukas Vischer (Grand Rapids: W. B. Eerdmans, 2003).

${ }^{8}$ Davies, English Puritans, 103-08.

${ }^{9}$ Ibid., 108-10.

${ }^{10}$ Directory, 2-3.

${ }^{11}$ For example ibid., 8.

${ }^{12}$ Davies, Worship and Theology, Vol 2, 406.
} 
great abuse in practice was a tendency towards prolixity, diffuseness, disorder, and a chain reaction of clichés. ${ }^{13}$

While accepting the possibility of inordinate length Murray points out that rather than complaints we often read of enjoyment in such prayers, and hence we should be careful not to assume the worst of them. ${ }^{14}$ Murray is however picking up on the comments of ministers and we can probably assume that such prayers were not always enjoyed.

After the restoration the Anglican Prayer Book was imposed despite attempts by moderate Presbyterians such as Richard Baxter to propose a compromise solution. ${ }^{15}$ Davies suggests one effect of the resulting persecution was to endear the concept of free prayer to the Presbyterians as well as the Congregationalists. ${ }^{16}$

While arguments raged over public prayer there was relative agreement over the practice of private prayer. This was accepted to be a key element in personal piety and was seen to require instruction and guidance resulting in the publication of numerous prayer manuals. ${ }^{17}$ A common theme within these is that prayer must not only be frequent but fervent in nature, as this is the prayer that God hears. Garrett says, 'The assumption throughout is that Christians do or should feel intense emotion in their relations with God and that this emotion serves as the main impetus for prayer., ${ }^{18}$ However, it was also recognised that such emotion was not always present in the heart of the believer and hence advice was given for raising the passions. ${ }^{19}$

\footnotetext{
${ }^{13}$ Ibid., 191.

${ }^{14}$ Murray, "Directory," 186.

${ }^{15}$ His proposal was the Savoy Liturgy of 1661; see Davies, Worship and Theology, Vol 2, 426-34.

${ }^{16}$ Ibid., 450.

${ }^{17}$ See the overview by Cynthia Garrett, "The Rhetoric of Supplication: Prayer Theory in SeventeenthCentury England," Renaissance Quarterly 46, no. 2 (1993).

${ }^{18}$ Ibid., 339.

${ }^{19}$ On private prayer see Ian M. Green, "New for Old? Clerical and Lay Attitudes to Domestic Prayer in Early Modern England," Reformation and Renaissance Review 10, no. 2 (2008).
} 


\subsection{Prayer in the eighteenth century}

Within the Church of England the prayer book dominated through the eighteenth century. Indeed this period has been called the golden age of the prayer book. ${ }^{20}$ Within dissent there was a continuation of extempore prayer. The arguments for and against set prayer continued to be rehearsed and had not materially changed from the previous century. ${ }^{21}$ Spinks suggests that with toleration came a mellowing of attitudes over this issue: previously rejection of liturgy had gone hand in hand with persecution, but now there was less at stake. ${ }^{22}$

Despite this mellowing of attitudes publications continued to debate the issue. For example a weighty treatise by Thomas Bennet arguing for set forms of prayer was replied to by two dissenters, John Horsley and Jeremiah Wainewright. ${ }^{23}$ The Bishop of London published the proceedings from a conference with his clergy on the topic arguing for only set prayers to be used in public. He published this, he says, because of the prevalence of the 'Spirit of Enthusiasm', and the 'fatal effects' of praying extempore. ${ }^{24}$ Other Anglicans also wrote against the free prayers of dissenters although some cautiously allowed free prayer in private. ${ }^{25}$ There was also outright ridicule of free

\footnotetext{
${ }^{20}$ Jeremy Gregory, "'For All Sorts and Conditions of Men': The Social Life of the Book of Common Prayer during the Long Eighteenth Century: or, Bringing the History of Religion and Social History Together," Social History 34, no. 1 (2009): 32.

${ }^{21}$ Davies, Worship and Theology, Vol 3, 106. A later example can be seen in Samuel Palmer, The Protestant-Dissenter's Catechism (London: J. Buckland, 1774), 39-41, 49-53.

${ }^{22}$ Brian D. Spinks, Freedom or Order?: The Eucharistic Liturgy in English Congregationalism, 16451980 (Allison Park, Pa.: Pickwick Publications, 1984), 18.

${ }^{23}$ Thomas Bennet, A Brief History of the Joint Use of Precompos'd Set Forms of Prayer (Cambridge: Edmund Jeffery, 1708). John Horsley, A Brief Reply to the Scriptural and Argumentative Part of Mr. Bennet's Brief history of the Joint Use of Precomposed Set Forms of Prayer (London: Whattoff Boulter, 1708). Jeremiah Wainewright, Brief Remarks on Mr. Bennet's Brief History of the Joint Use of Precomposed Set Forms of Prayer (London: J. Humfreys, 1708).

${ }^{24}$ Henry Compton, Whether Set-Forms of Prayer be not Very Necessary in the Publick Worship of God (London: Benj. Motte, 1707), A2.

${ }^{25}$ See for example Thomas Edwards, A Discourse of Praying in the Spirit: or Against Extemporary Prayer (London: Robert Clavel, 1703), 41-45; Theophilus Dorrington, The Plain Man's Gift of Prayer: Shewing What it is, and Directing the Use of it in his Family (London: John Wyat, 1703).
} 
prayer as 'Extemporary Gibberish' in some quarters which received equally strong rebuttals. ${ }^{26}$ Some dissenters wrote not only of how set prayers were an unnecessary restriction but also that such use was a sinful quenching of the Spirit. ${ }^{27}$

We get some insight into dissenting prayer from a record of services at Watts' own church. Within the outline of a service we are told of a main prayer:

...the minister prays more at large, for all the variety of blessings, spiritual and temporal, for the whole congregation, with confession of sins, and thanksgiving for mercies; petitions also are offered up for the whole world, for the churches of Christ, for the nation in which we dwell, for all our rulers and governors, together with any particular cases which are represented. ${ }^{28}$

Sell says that while there was a great deal of variety to be found this is a typical example. ${ }^{29}$ Davies gives another example of Samuel Brewer at the independent church in Stepney who was known for his great detail such that his congregation heard all the local news through his pastoral prayer. Davies comments that these extempore prayers of conservative dissent, while pastorally focused, were very long and tedious. ${ }^{30}$

There continued to be many publications to aid people in private prayer. One of the most significant of these was Matthew Henry's Method for Prayer. ${ }^{31}$ This argued for free prayer but with the provision of scriptural expressions to be used by the supplicant, so aiding them in what to say. From the Anglican side there was the publication of $A$

\footnotetext{
${ }^{26}$ Jacob Curate, The Scotch Presbyterian Eloquence (London Randal Taylor, 1692), 2. George Ridpath, An Answer to The Scotch Presbyterian Eloquence (London: Tho. Anderson, 1693).

${ }^{27}$ See for example James Barry, A Help to Prayer: Or, a Serious and an Impartial Discourse of Right Prayer (London: John Marshall, 1701).

28 "Transactions of the Congregational Historical Society," VI (1913-15): 334.

${ }^{29}$ Alan P. F. Sell, "The Worship of English Congregationalism," in Christian Worship in Reformed Churches Past and Present, ed. Lukas Vischer (Grand Rapids: W.B. Eerdmans, 2003), 89-91.

${ }^{30}$ Davies, Worship and Theology, Vol 3, 106-07. Sell agrees with the tendency towards prolixity in dissent, Sell, "English Congregationalism," 94.

${ }^{31}$ Matthew Henry, A Method for Prayer, with Scripture Expressions Proper to be Us'd under Each Head (London: Nath. Cliff and Daniel Jackson, 1710).
} 
New Form of Prayer by Henry Sacheverell. ${ }^{32}$ This contained written prayers and collects, as well as selections of scripture. Edmund Gibson also produced an encouragement to family prayer with forms to be used. ${ }^{33}$

We noted in the previous chapter the Eastcheap lectures on praise given by a number of dissenting ministers. These lectures were followed in 1711 by a similar series on prayer. ${ }^{34}$ The preface notes the poor conduct of prayer in dissenting churches and the need for reform. We will return to these lectures in comparing Watts with his contemporaries.

Lori Branch presents a thesis regarding free prayer that begins in the seventeenth century and develops through the eighteenth. ${ }^{35}$ She identifies the key desired features of free prayer as authenticity and sincerity which resulted in spontaneous outpouring from the heart. This is seen to have a significant pastoral consequence: such prayer is taken as evidence of one's spiritual condition. A good heart is the source of true free prayer, and hence prayer is seen as evidence of such a heart. Branch argues that this is an example of an empirical approach reflecting the new science of the day. ${ }^{36}$

Branch postulates that this produced anxiety over performing prayer spontaneously, and it is this anxiety that lies behind texts produced on prayer such as those by Henry and Watts. Henry's providing phrases to use in prayer is seen as an admission that someone looking for authentic inner substance might instead find silence. This anxiety generates

\footnotetext{
${ }^{32}$ Henry Sacheverell, A New Form of Prayer for Morning and Evening, for the Use of Families Zealously Affected to the Establish'd Church (London: J. Baker, 1710).

${ }^{33}$ Edmund Gibson, Family-Devotion: or, an Exhortation to Morning and Evening Prayer in Families (London: 1705).

${ }^{34}$ Practical Discourses Concerning the Duty of Prayer: Preach'd at the Friday Evening-Lecture in Eastcheap. By Several Ministers, (London J. Darby, 1711).

${ }^{35}$ Lori Branch, Rituals of Spontaneity: Sentiment and Secularism from Free Prayer to Wordsworth (Waco: Baylor University Press, 2006).

${ }^{36}$ Ibid., 43-44.
} 
a self-scrutiny which undermines sincerity and assurance, and develops a sense that prayer is labour and performance. ${ }^{37}$

Branch also points to a utilising of economic terminology in prayer books. Extempore prayer is seen as current rather than outdated, and hence of greater worth. In addition prayer is seen as labour that must be performed correctly to receive from God:

...free prayer is not just evidentiary experience of grace but - contrary to explicit reformed doctrine - work, a task performed in costume or livery, to be appraised by a divine master or employer from whom one hopes, rather anxiously, to be paid grace or salvation. ${ }^{38}$

As Watts is specifically quoted as an example of these trends we will return to examine them once we have looked at Watts' theology of prayer.

\section{Watts on prayer}

\subsection{Introduction}

Watts produced A Guide to Prayer in 1715 and in the preface he speaks candidly about the need for instruction to reform the practice of prayer. ${ }^{39}$ In 1728 he published Prayers Composed for the Use and Imitation of Children. Both of these works were popular and were republished many times; in fact Watts' Guide is one of the few of his prose works to be reprinted more recently. ${ }^{40}$ Watts also refers to prayer in his other works especially in some of his sermons. We will draw primarily on his Guide but also on his wider works in what follows and again see how Watts' view of reason and passion shaped his position on prayer.

\footnotetext{
${ }^{37}$ Ibid., 52-56.

${ }^{38}$ Ibid., 51-52.

${ }^{39}$ For an overview of this see John H. Taylor, "Isaac Watts' Guide to Prayer," Transactions of the Congregational Historical Society XVIII (1956-1959).

${ }^{40}$ Isaac Watts, Isaac Watts's A Guide to Prayer. Abridged and Edited by Harry Escott (London: Epworth Press, 1948); Isaac Watts, A Guide to Prayer (Edinburgh: Banner of Truth Trust, 2001); Isaac Watts and Hal McElwaine Helms, So Amazing, So Divine: A Guide to Living Prayer (Brewster, Mass.: Paraclete Press, 1997).
} 
Watts begins his Guide by outlining his aims. He believes many publications have taught the 'inward and spiritual performance' of prayer, but what has been lacking is a practical guide to give a 'scheme' of prayer as a piece of 'holy skill'. So he is providing material on the 'form, method and expression' of prayer. ${ }^{41}$ The Guide then is a manual both for the help of the average Christian in their prayer life, and for the reform of public prayer in churches. Watts acknowledges the helpfulness of previous publications of people such as Henry and Robert Murrey in providing phrases and prayers that will assist the believer. ${ }^{42} \mathrm{He}$ also says he has particularly followed John Wilkins and John Owen in sections of his discourse. ${ }^{43}$

\subsection{Overview}

We will briefly overview Watts' view of prayer and then move to examine the place of reason and passion more fully. Watts defines prayer as including all addresses between man and God, rather than being limited to petition. He says:

It is that language, wherein a creature holds correspondence with his creator: and wherein the soul of a saint often gets near to God, is entertained with great delight, and, as it were, dwells with his heavenly father for a short season before he comes to heaven. ${ }^{44}$

Prayer is seen to be part of our worship and duty and is to be performed by individuals, in families, and at church gatherings. Watts' first section on the nature of prayer divides it into nine sections. ${ }^{45}$ For each of these he gives an explanation of the function of this part of prayer and then gives terms and phrases that someone might use. This is in the form of suggested expressions rather than a prayer to be repeated.

\footnotetext{
${ }^{41}$ Watts, Works, 'Prayer', Volume 3, 105.

${ }^{42}$ Henry, Method for Prayer. Robert Murrey, Closet Devotions: In which the Principal Heads of Divinity are Meditated Upon, and Pray'd Over, in Scripture Expressions (London: John Lawrence, 1713).

${ }^{43}$ John Wilkins, A Discourse Concerning the Gift of Prayer (London: T.R. and E.M., 1651); John Owen, A Discourse of the Work of the Holy Spirit in Prayer (London: Nathanael Ponder, 1682).

${ }^{44}$ Watts, Works, 'Prayer', Volume 3, 109.

${ }^{45}$ Such as 'invocation', 'adoration', 'confession', 'petition', etc.
} 
The later sections of the book describe the gift, grace and spirit of prayer. The gift of prayer is the 'ability to suit our thoughts to all various parts and designs of this duty, and a readiness to express those thoughts before God in the fittest manner to profit our own souls, and the souls of others that join with us. ${ }^{46}$ Watts explains that it is called a gift because the work of the Spirit is required to attain it; but this does not mean it cannot be taught in a 'rational method by proper directions and rules.'

The gift of prayer then is the outward performance; by comparison the grace of prayer is the inward disposition that comes from God's work of grace in us. So the grace of prayer is 'the soul and spirit, that gives it life, and vigour, and efficacy, that renders it acceptable to God, and of real advantage to our selves. ${ }^{47}$ It is possible then to have the gift of prayer but not the reality of the grace of prayer.

The spirit of prayer refers to the work of the Holy Spirit in aiding Christians such that they attain the gift and grace of prayer, as well as other helps. ${ }^{48}$ Watts here critiques those who attribute too much and too little to the Spirit in prayer and gives cautions concerning his work.

Watts comments in his preface on the strident contention there has been over set forms which we have described above. His comment on these opposing parties is very instructive:

But if the leaders of one party had spent as much time in learning to pray, as they have done in reading liturgies, and vindicating their imposition; and if the warm writers of the other side, together with their just cautions against quenching the spirit, had more cultivated this divine skill themselves, and taught christians regularly, how to pray; I believe the practice of free-prayer

\footnotetext{
${ }^{46}$ Watts, Works, 'Prayer', Volume 3, 123.

${ }^{47}$ Ibid., 'Prayer', Volume 3, 160.

${ }^{48}$ These definitions were common in the previous century. For example Henry Dawbeny, A Sober and Temperate Discourse, Concerning the Interest of Words in Prayer, the Just Antiquity and Pedigree of Liturgies, or Forms of Prayer in Churches (London Printed for W.A., 1661), 7-8.
} 
had been more universally approved, and the fire of this controversy had never raged to the destruction of so much charity. ${ }^{49}$

Behind this critique is Watts' theology of prayer: in brief, that reason must be used in correct formulation of the matter of prayer, but that passionate personal expression must also be allowed. Hence Watts' aim in writing is explained as follows:

My design in this treatise has been to write a prayer-book without forms. And I have sought to maintain the middle way between the distant mistakes of contending christians. ${ }^{50}$

Watts lands firmly on the side of free prayer, but is not identical to many of those who also contended for it. ${ }^{51} \mathrm{He}$ goes on to allow for set forms of prayer, but only as aids. ${ }^{52}$ So, on the vexed topic of the Lord's Prayer he believes it is a pattern given to the disciples in their 'infant state', but it is not a set form to be repeated. ${ }^{53}$ Watts happily acknowledges the help that set forms can be, but argues against being limited to them. This is seen in his Humble Attempt where he refers approvingly to the Directory of Worship of the Westminster Assembly as a pre-composed liturgy in which there is liberty for the minister to add or change elements. ${ }^{54}$ Watts' scheme of prayer is similar to this in giving a framework and suggested matter for prayer, while leaving great liberty for the individual to pray as they wish. As Gravlee and Irvine say:

The result is a well developed rhetorical invention, with a system of commonplaces, an identification of sources, which can contribute to

\footnotetext{
${ }^{49}$ Watts, Works, 'Prayer', Volume 3, 106.

${ }^{50}$ Ibid., 'Prayer', Volume 3, 106.

${ }^{51}$ Watts also rehearses these arguments in ibid., 'Reliquiae Juveniles', Volume 4, 537-42.

${ }^{52} \mathrm{He}$ sees greater use for set forms in private settings, such as in his recommendation of Samuel Bourn, The Christian Family Prayer Book: or, Family Prayers for Morning and Evening; with a Variety of Occasional Forms. Recommended by Dr I. Watts (London: Richard Ford, 1737).

${ }^{53}$ Watts, Works, 'Prayer', Volume 3, 124.

${ }^{54}$ Ibid., 'Humble Attempt', Volume 3, 57.
} 
substance, and a recognition of contextual variables that influence the entire process. $^{55}$

It is particularly important to see that Watts distinguishes between different forms of free prayer. There is what he calls 'conceived or free prayer' which is different to 'extempore prayer'. ${ }^{56}$ The latter is when one prays with no forethought or consideration as to the matter and expression; the former is where consideration and meditation on these issues has taken place before praying, but the words of the prayer have not been committed to writing such that it is repeated. Watts allows for extempore prayer in a variety of situations but his preference, especially for public settings, is for conceived prayer. ${ }^{57}$ This is his 'middle way': carefully prepared and thoughtful prayer, but with freedom of expression. So as Gravlee and Irvine say, 'he eschews the impromptu of Enthusiasts and the manuscript of Anglicans. ${ }^{58}$

Watts' prayers for children clearly present set forms and he discusses this issue in the preface. He sees set forms as an aid which can stimulate even the prayers of adults as long as they are used wisely. Wise use involves not employing them as a direct form of worship, but rather making use of expressions within them and then adding, subtracting or enlarging as needed. ${ }^{59}$

For children however Watts believes providing set forms is appropriate because of their inability to know how to pray. However he is explicit that he sees this as a temporary phase and has even included some features in his prayers, such as variety of expressions, to aid children 'in their advancing years to pray without a form, which design I have always kept in view. ${ }^{, 6}$

\footnotetext{
${ }^{55}$ G. Jack Gravlee and James R. Irvine, "Watts' Dissenting Rhetoric of Prayer," Quarterly Journal of Speech 59, no. 4 (1973): 468.

${ }^{56}$ It is worth noting that Gravlee and Irvine mistake Watts on this saying that he speaks of three forms of prayer and recommends 'extempore' prayer. Ibid., 464.

${ }^{57}$ Watts, Works, 'Prayer', Volume 3, 127-28.

${ }^{58}$ Gravlee and Irvine, "Rhetoric of Prayer," 469.

${ }^{59}$ Watts, Works, 'Prayers for Children', Volume 3, 496.

${ }^{60}$ Ibid., 'Prayers for Children', Volume 3, 500.
} 
In discussion of whether set words are used Watts comments on the key aspects of prayer:

It is not our own composing of a prayer, nor the reading of a prayer composed, nor the saying it over without book, or repeating it after another, that is either necessary or sinful in it self: But it is the understanding and the inward desire and affection accompanying the words, that render the work of prayer pleasing to God: And it is the want of that understanding, desire and affection, that will spoil all pretences to devotion, whether the words be read or said without book. ${ }^{61}$

Here is the heart of prayer for Watts: prayer with understanding and affection. We should note that this is exactly what we saw in his view of praise. We will now examine each of those areas in more detail and trace the connections to Watts' underlying thought regarding reason and passion.

\subsection{Reason in prayer}

We first see Watts' view of reason expressed in prayer in a similar way to that of praise: that is he is greatly concerned with the understanding of those praying. This is seen in numerous ways. In his prayers for children he writes prayers for different age groups, increasing in complexity with age. His explanation of this approach is this:

I am well satisfied that the best way of teaching children, both in matters divine and human, is to lead them into some tolerable idea and conception of all the things signified by the words they are taught to use, as soon as those words are taught them; that they may not be accustomed, even in their younger days, to deal in mere sounds, to talk without ideas, and to speak words and syllables without a meaning. ${ }^{62}$

Here we see Watts' Lockean view that we should never be content to have 'words without ideas' being applied to teaching children to pray. He speaks again about the significance of understanding when commenting on children learning prayer by rote:

\footnotetext{
${ }^{61}$ Ibid., 'Prayers for Children', Volume 3, 502.

${ }^{62}$ Ibid., 'Prayers for Children', Volume 3, 498.
} 
It is hard work to learn any set of words without a meaning to them; And there is as little religion in it, as there is reason, though the words, with their proper meaning, may carry never so much reason and religion in them. ${ }^{63}$

This requirement of clear understanding applies to adults as well. Watts warns against the use of scriptural phrases in prayer when they are used out of context and when it involves the use of 'dark sentences' which no one can understand; and also against obsolete or foreign words and the philosophical language of 'mystical divinity' ${ }^{64} \mathrm{His}$ concern is that people are captivated by fine sounding phrases which move them to raptures, when in reality it is 'sound without sense.'

Watts comments on the role of language in prayer for adults: 'Expressions are useful, not only to dress our thoughts, but sometimes to form and shape, and perfect the ideas and affections of our minds. ${ }^{65}$ Watts sees usefulness in our words here to both reason and passion and we will return to this statement later in addressing passion. For reason though having to 'dress our thoughts' into particular words gives them a clearer shape, and hence we know what it is we are saying more accurately. Watts acknowledges that words are not necessary for prayer, but his view of reason means he wants to push people to know precisely what they are expressing.

Watts also speaks of expending effort to render prayer in the most 'plain, familiar, and easy language.' He warns: 'avoid length and obscurity in your sentences, and in the placing of your words; and do not interline your expressions with too many parentheses, which cloud and entangle the sense. ${ }^{66}$ He also speaks of structuring preconceived prayer for public gatherings with a view to understanding: 'Method is necessary to guide our thoughts, to regulate our expressions, and dispose of the several parts of prayer in such an order as is most easy to be understood by those that join with us. ${ }^{, 67}$

\footnotetext{
${ }^{63}$ Ibid., 'Prayers for Children', Volume 3, 502.

${ }^{64}$ Ibid., 'Prayer', Volume 3, 142-45.

${ }^{65}$ Ibid., 'Prayer', Volume 3, 140.

${ }^{66}$ Ibid., 'Prayer', Volume 3, 143-44.

${ }^{67}$ Ibid., 'Prayer', Volume 3, 137.
} 
This results in directions for prayer such as speaking in general terms before particulars, and collecting similar areas together. ${ }^{68}$ Here we see Watts as the Enlightenment teacher of logic, giving instruction in prayer.

We also see Watts' understanding of the relationship reason has as the foundation for passion in his structuring of prayer. He says:

Let those things, in every part of prayer, which are the proper objects of our judgment, be first mentioned, and then those that influence and move our affections... there is occasion frequently in prayer, under the several parts of it, for the recollecting of divine truths, and these lay a proper foundation for warm and pathetical expressions to follow. ${ }^{69}$

In all these areas we see a great similarity with the influence of reason on Watts' view of $_{\text {praise. }}{ }^{70}$

Secondly Watts is concerned to demonstrate the reasonableness of prayer. This is seen in a significant part of Watts' title for his Guide; it is a 'Free and Rationale Account of the Gift, Grace and Spirit of Prayer.' Watts explains further in his preface saying that these aspects of prayer have been 'made the subject of plentiful ridicule.' He admits that some people have explained these terms in too exalted a sense which brings such ridicule, but his desire is to explain them in their 'proper and rationale meaning' and so free people from the charge of enthusiasm. ${ }^{71}$

Hence later, in introducing the gift of prayer, Watts says he aims to give a 'rational account of it' so that 'the unjust reproach be wiped away forever. ${ }^{72}$ Similarly in speaking of the method of prayer he says:

\footnotetext{
${ }^{68}$ In this Watts is echoing Wilkins, Gift of Prayer, 38.

${ }^{69}$ Watts, Works, 'Prayer', Volume 3, 138.

${ }^{70}$ There is also similarity in avoiding contentious issues and so providing a book for different denominations.

${ }^{71}$ Watts, Works, 'Prayer', Volume 3, 106.

${ }^{72}$ Ibid., 'Prayer', Volume 3, 122-23.
} 
...the Spirit of God when he is poured out as a spirit of prayer in the most glorious measures, doth not contradict the rules of a natural and reasonable method, although his methods may have infinite variety in them. ${ }^{73}$

Or again:

I think there is enough in the second chapter of this treatise to convince impartial men, that the gift of prayer is no enthusiastical pretence, no insignificant cant of a particular party; but an useful and necessary qualification for all men; a piece of christian skill to be attained in a rational way. $^{74}$

Hence there is a strong theme of both explanation and justification of prayer itself and the believer's experience of prayer. In this we can see reflections of Watts' vindication of Christian experience as eminently reasonable. ${ }^{75}$

This leads Watts to be concerned about the decency with which public prayer is performed. He says: 'The credit of religion in the world is much concerned with the honourable discharge of the duty of prayer. ${ }^{76} \mathrm{He}$ goes on to speak of the sense of order that must prevail, even when the worship is led by 'immediate inspiration'. He continues:

But if ye are guilty of disorder in speaking, and break the rules of natural light and reason in uttering your inspirations, the unlearned and unbelievers will say, ye are mad, though your words may be the dictates of the holy Spirit. $^{77}$

Here we see Watts' strong view of the role of reason and the light of nature such that we must act in line with them, even when inspired by the Spirit. He does not say, as we might have expected, that if the Spirit were inspiring someone he would be led to speak

\footnotetext{
${ }^{73}$ Ibid., 'Prayer', Volume 3, 137.

${ }^{74}$ Ibid., 'Prayer', Volume 3, 188.

${ }^{75}$ See Chapter 2, section 6.1.

${ }^{76}$ Watts, Works, 'Prayer', Volume 3, 192.

${ }^{77}$ Ibid., 'Prayer', Volume 3, 193.
} 
decently. Rather Watts sees the presentation and delivery of prayer as under the control of the individual who must not abdicate responsibility for it under claims of inspiration. Hence the rules of reason are never contravened on the basis of God's direct influence. This is a rebuke to those Watts considers too enthusiastic in prayer, and who tarnish the reputation of free prayer. However he also challenges those who would 'entertain nothing in religion but what appears agreeable to the principles of reason and philosophy.' He goes on to argue for the assistance of the Spirit in prayer as an eminently reasonable but supernatural work.

Here then is Watts' balancing act: enthusiasts must act in line with the light of nature, but deists must be challenged to accept the supernatural element of prayer. The guiding principle that steers Watts through is his nuanced view of the role of reason which we have examined. God never wants us to act contrary to reason, our experience of him is eminently reasonable, and yet there is more to our experience of God than reason.

Lastly we see Watts' view of reason in his belief that the gift of prayer is something that can be learnt. This draws on his view of education, especially with regard to theological matters. We recall that Watts believed in the consonance of the empirical process of discovery and reasoning, and the assistance of God. ${ }^{78}$ So in speaking of growth in the ability of prayer he says:

As the art of medicine or healing is founded on the knowledge of natural principles, and made up of several rules drawn from the nature of things, from reason and observation ... so the holy skill of prayer is built on a just knowledge of God and ourselves, and may be taught in as rational a method by proper directions and rules. ${ }^{79}$

But, Watts insists, this does not mean that the assistance of the Holy Spirit is eliminated. Rather in such learning 'we expect the aids of the holy Spirit in things so serious and sacred.'

\footnotetext{
${ }^{78}$ See Chapter 2, section 2.

${ }^{79}$ Watts, Works, 'Prayer', Volume 3, 123.
} 


\subsection{Passion in prayer}

The place of passion in prayer is first seen in Watts' nuanced opposition to set forms of prayer. His concern with set forms reflect the standard criticisms of dissent over the previous decades: they were too impersonal, had potential for hypocrisy, and elevated the particular form of words used. However within this Watts has a specific focus on the passions. In a similar way to that which we saw in praise, Watts speaks of the limits that arise if we speak only in the general terms of a set prayer rather than express our own situation and experience:

...generals are cold and do not affect us, nor affect persons that join with us, and whose case he that speaks in prayer should represent before God. It is much sweeter to our own souls, and to our fellow-worshippers, to have our fears, and doubts, and complaints, and temptations, and sorrows represented in most exact and particular expressions, in such language as the soul itself feels when the words are spoken. ${ }^{80}$

We notice the ideal of the soul to feel the words that are spoken. This need for feeling means Watts speaks negatively of set forms:

... while we bind ourselves to those words only, we damp our inward devotion, and prevent the holy fire from kindling within us; we discourage our active powers and passions from running out on divine subjects, and check the breathing of our souls heaven-ward. ${ }^{81}$

He goes on:

The thoughts and affections of the hearts that are truly pious and sincere, are wrought in us by the Spirit of God, and if we deny them utterance because they are not found in prayer-books, we run the danger of resisting the holy Ghost. $^{82}$

Here Watts' doctrine of the passions is very much in play: we have seen his concern that sanctified passions, especially love for God, are both excited and expressed by

\footnotetext{
${ }^{80}$ Ibid., 'Prayer', Volume 3, 126.

${ }^{81}$ Ibid., 'Prayer', Volume 3, 124-25.

${ }^{82}$ Ibid., 'Prayer', Volume 3, 125.
} 
Christians. Along with praise, prayer is a key moment in which this is happens. Hence Watts is very wary of anything that damps such passions, and is concerned that we will suppress such God-given affection. When giving advice on how to obtain the 'spirit of prayer' he warns more directly: 'Quench not the Spirit of prayer by confining yourselves to any set forms whatsoever. ${ }^{83}$

In his Humble Attempt this results in Watts exhorting dissenters to make the most of this advantage of freedom in prayer:

Are you more lively in the freer addresses of your souls to heaven without a confinement to set words and phrases? Are your spirits more humble, and your devotional thoughts in warmer exercise, while you are adoring the great and blessed God in a larger variety of language? Are your hearts more deeply affected... ${ }^{84}$

This is a very similar argument to that seen in Watts' view of praise: free use of language is needed to express the experience of the believer, so as to allow expression of godly passions. ${ }^{85}$

Watts' view of excitation of the passions is also seen in some of his practical advice in prayer. This includes the reading of affecting passages of Scripture; the collecting of expressions that have been affecting in the past for future use; and the use of Scripture phrases in prayer which are seen to be passionate in nature. ${ }^{86}$

Watts' theology of the passions also directs his recommendations on use of language. We saw the statement above that: 'Expressions are useful, not only to dress our thoughts, but sometimes to form and shape, and perfect the ideas and affections of our minds. ${ }^{87}$ Watts believes that correct and appropriate expression is essential to prayer

\footnotetext{
${ }^{83}$ Ibid., 'Prayer', Volume 3, 185.

${ }^{84}$ Ibid., 'Humble Attempt', Volume 3, 58.

${ }^{85}$ See also ibid., 'Love of God', Volume 2, 667.

${ }^{86}$ Ibid., 'Prayer', Volume 3, 131, 41-42.

${ }^{87}$ Ibid., 'Prayer', Volume 3, 140.
} 
because it perfects not only what we are praying for but how we feel about it. Language aids expression of passion.

Branch takes Watts' comment on 'dressing' as meaning that language is being used to cover over the lack of emotion in the heart of the believer. ${ }^{88}$ However this is surely to read Watts against himself, as he is saying that the dressing of our thoughts in language is useful to clarify exactly what we mean and feel. Watts also explicitly warns against the masking of a lack of inward devotion in his work on prayer and that on passion. ${ }^{89}$

Watts also sees appropriate language as stirring passion in us in prayer; the right words 'awaken the holy passions of the soul as well as to express them. ${ }^{90}$ His view is summarised:

When our souls are filled with a lively impression of some of the attributes, or works of God, when our hearts are overpowered with a sense of our own guilt and unworthiness, or big with some important request; $\mathrm{O}$ what a blessed pleasure it is to hit upon a happy expression, that speaks our very soul, and fulfils all our meaning! and what a pleasure doth it convey to all that join with us, who have their spiritual senses exercised? and it helps to excite in them the same devotion that dictated to us the words we speak. ${ }^{91}$

This view of language and passion means that the person leading prayer should seek to find expressions that not only fit their own heart, but which will also raise the passions of their listeners:

Seek after those ways of expression that are pathetical, that denote the fervency of affection, and carry life and spirit with them; such as may awaken and exercise our love, our hope, our holy joy, or sorrow, our fear, and our faith, as well as express the activity of those graces. This is the way to raise, assist and maintain devotion. ${ }^{92}$

\footnotetext{
${ }^{88}$ Branch, Rituals of Spontaneity, 51.

${ }^{89}$ Watts, Works, 'Prayer', Volume 3, 143; 'Love of God', Volume 2, 689.

${ }^{90}$ Ibid., 'Prayer', Volume 3, 140.

${ }^{91}$ Ibid., 'Prayer', Volume 3, 143.

92 Ibid., 'Prayer', Volume 3, 146.
} 
Watts goes on to list modes of expression which are useful for this aim in prayer. $\mathrm{He}$ also speaks of the appropriate manner and gesture to suit and reflect the corresponding passions. For example: 'Fervency of spirit in our petitions, and holy joy when we give thanks to our God for his mercies, and rejoice in our highest hope, will be discovered by very agreeable and pleasing traces in the features and countenance. ${ }^{93}$ These comments echo Watts' comments about passion in preaching.

In addition the person leading prayer should be less concerned with the rules of rhetoric and more concerned with raising their own passions. Again, as with preaching, this will lead to appropriate expression:

The passions of the mind, when they are moved, do mightily help the tongue. They fill the mouth with arguments; they give a natural eloquence to those who know not any rules of art; and they almost constrain the dumb to speak. $^{94}$

The place of the passions also appears in Watts' view of the grace of prayer, that is its inward nature. Watts says that the gift of expression in prayer can have the appearance of 'holy desires and affections' but only the grace of prayer has the reality of these. ${ }^{95}$ Such reality is desperately needed: God 'is not taken with the brightest forms of worship, if the heart be not there. ${ }^{96}$ He goes on to describe the inner reality that corresponds to each part of prayer. So for example:

The work of adoration or praise, runs through the several attributes of the divine nature, and requires of us the exercise of our various affections suited to those several attributes. As when we mention God's self-sufficiency and independency, it becomes us to be humble and acknowledge our dependence: when we speak of his power, and of his wisdom, we should abase ourselves before him... When we mention his love and compassion,

\footnotetext{
${ }^{93}$ Ibid., 'Prayer', Volume 3, 153.

${ }^{94}$ Ibid., 'Prayer', Volume 3, 140.

${ }^{95}$ Ibid., 'Prayer', Volume 3, 160-61.

${ }^{96}$ Ibid., 'Prayer', Volume 3, 196-97.
} 
our souls should return much love to him, and have our affections going forth strongly towards him. ${ }^{97}$

Watts continues in this vein for each part of prayer: confession requires shame and indignation against sin, intercession for others requires compassion on them, and so on. A caution is added in case people should conclude that they do not feel enough when praying: 'all the graces of prayer are seldom at work in the soul at once, in an eminent and sensible degree' because of our 'feeble and imperfect state. ${ }^{98}$ Hence here we have Watts' doctrine of the passions applied directly to what the believer should feel in prayer.

While the grace of prayer is seen as the work of the Spirit, it too can be worked at by the believer through ordinary means. Watts gives very similar instructions to those we saw for the excitation of the passions generally: that the believer should call to mind and meditate on the truth of the matter in question and so cultivate the appropriate heart attitude, as well as calling for the aid of the Spirit.

In discussing the work of the Spirit in prayer there is overlap with Watts' view of the extraordinary witness of the Spirit which we have already seen. He believes there are times when the Spirit so aids those in prayer as to bring extraordinary moments that cannot be accounted for by normal factors:

Some persons at special seasons will break out into a divine rapture in prayer, and be carried far beyond themselves: their thoughts, their desires, their language, and everything that belongs to their prayer, seems to have something of heaven in it. ${ }^{99}$

However Watts' main concern is to rightly instruct people on how the Spirit aids us. He believes those who deny the Spirit's special influences attribute too little to his work. Equally some attribute too much, such as always expecting prompting to pray or making our study of prayer unnecessary. Watts seeks a 'happy median' between these two

\footnotetext{
${ }^{97}$ Ibid., 'Prayer', Volume 3, 162-63.

${ }^{98}$ Ibid., 'Prayer', Volume 3, 164.

${ }^{99}$ Ibid., 'Prayer', Volume 3, 171.
} 
positions whereby the Spirit assists and aids our natural capacities and instructs us in a variety of ways in prayer. With regard to the passions Watts says:

He excites those graces in us, which are suited to the duty of prayer. He spiritualizes our natural affections, and fixes them on proper objects, and enlarges and heightens their activity. ${ }^{100}$

So for example:

When sin is recollected, he awakens anger, shame and sorrow. When God is revealed to the mind in his glory and justice, he overspreads the soul with holy awe, and humble fear. When the Lord Jesus Christ, and his redemption, are upon the thoughts, the holy Spirit warms and raises our desire and love. We are in ourselves cold and dead to spiritual things, he makes us lively in prayer, and holds us to the work; he begets a holy reverence of God while we adore him; he works in us delight in God and longing desires after him. ${ }^{101}$

We recall Watts' view of how the Spirit reorders and sanctifies the passions: this is that work now applied to the duty of prayer. Watts sees this work of the Spirit as the only source of authentic prayer. Affections raised by the Spirit in the heart then have a natural influence on the rest of prayer such as expression and voice. He goes on:

And, for the most part, the utterance will be proportional to the degree of inward affection, and to the natural and acquired abilities of the person that prays; excepting some rare and glorious instances, where men are carried beyond themselves, by the uncommon presence of the divine Spirit. ${ }^{102}$

This is parallel to Watts' view of the ordinary and extraordinary witness of the Spirit; in many ways it is that same view applied to the Spirit's work in prayer.

As in Watts' works on the passions in general he also gives a variety of cautions concerning the passions in prayer. These include points such as: not all impressions to

\footnotetext{
${ }^{100}$ Ibid., 'Prayer', Volume 3, 176.

${ }^{101}$ Ibid., 'Prayer', Volume 3, 176.

${ }^{102}$ Ibid., 'Prayer', Volume 3, 177.
} 
pray come from the Spirit, the influences of the Spirit may not be distinguishable from natural abilities, and, the gift of prayer is not to be made the measure of grace. There is a repeat of the caution not to make the 'brightness and vehemence' of the experience the test as to whether it is from the Spirit, but rather the influence towards 'humility and growing holiness. ${ }^{103}$ This is again Watts' theology of the passions in general applied to prayer.

\section{Summary and comparison}

Watts' aim in writing on prayer is twofold and similar to that which we have seen in preaching and praise. He firstly wishes to defend passionate prayer as eminently reasonable. So he argues for the understanding of the different aspects of prayer as consistent with reason. He appeals to those who scoff at the idea of the Spirit assisting in prayer saying, 'Let me intreat you, Sirs, to tell me what there is in this doctrine that is unreasonable to assert, or unbecoming a philosopher to believe? ${ }^{104}$ Within this he calls those who use free prayer to ensure that they speak sense and do not give cause for ridicule in how they pray.

But Watts not only wishes to defend passionate prayer as reasonable, but to promote it as a spiritual practice to be encouraged and sought after. He carefully delineates the normal working of the Spirit and argues for this including an affect on the passions; he encourages use of passionate language and expression in prayer; and he also preserves room for the more extraordinary work of Spirit.

We have noted similarities in both his position and his argument to that in his view of praise and, to a lesser extent, preaching. His view of reason is seen especially in the importance of the understanding and the clear and distinct ideas represented in prayer. His view of passion is seen in the expectation of expression of emotion, the need for heart involvement, and the use of various means to excite and express passion in prayer.

\footnotetext{
${ }^{103}$ Ibid., 'Prayer', Volume 3, 181.

${ }^{104}$ Ibid., 'Prayer', Volume 3, 177.
} 
We noted Branch's analysis that authentic heartfelt prayer was seen as an evidential experience of grace and that this resulted in anxiety over its absence. Branch notes the tension produced by works to help people in producing such prayer: the need for aid undermines authenticity. So she says that Watts' directions to attain a rich treasure of expression is paradoxical because is supposed to be free prayer. ${ }^{105}$

However Branch fails to appreciate Watts' view of passion which lies behind his instruction. Watts believes that the Christian's heart has been transformed by the work of the Spirit so as to result in authentic godly passion which will show itself in prayer. However he also believes that this work is partial, such that ordinary means are still appropriate in aiding it. Hence Watts does not see authenticity and the work of education to be at odds with each other. Branch also does not deal with Watts' comments explicitly addressed to those who find they do not have the appropriate authentic feelings to pray. These comments show that he believes the work of the Spirit, and the ongoing need to sanctify our hearts and excite love for God, result in no paradox.

Branch also says that prayer for people like Watts was 'a task performed in costume or livery, to be appraised by a divine master or employer from whom one hopes, rather anxiously, to be paid grace or salvation. ${ }^{106}$ We have already noted that Watts' view on appropriate 'dressing' of language was actually to represent the content and desire of prayer more accurately, rather than being a costume to wear. Further, while Watts does occasionally use economic language as to what form of prayer 'counts' with God, this is with regard to what heart attitude God desires and responds to, for example the faith of the one praying. He also views prayer as the God appointed means to obtain his blessings which is itself a glorious privilege. In this context economic language need not turn prayer into a form of work that is repaid.

As with preaching and praise Watts was not alone in his view of prayer. Matthew Henry's Guide to Prayer shows similarity to Watts' approach, which should not

\footnotetext{
${ }^{105}$ Branch, Rituals of Spontaneity, 56.

${ }^{106}$ Ibid., 51-52.
} 
surprise us given Watts' recommendation of it. Henry gives both a logical scheme to prayer and scriptural expressions to aid the believer. In his preface he says there are times when there is:

...such a fervour of pious and devout Affections, the Product of which is such a Fluency and Variety of pertinent and moving Expressions, and in such a just and natural Method, that then to have an eye to such a Scheme as this would be a Hindrance to them, and would be in danger to cramp and straighten them: If the Heart be full of its good matter, it may make the Tongue as the Pen of a ready Writer. ${ }^{107}$

However Henry goes on, such times are not common, and hence the help of his book. Henry also speaks of the necessity of the heart in prayer:

'Tis only the effectual fervent Prayer, ...the in-wrought, in-laid Prayer that avails much. Thus therefore we ought to approve ourselves to God in the Integrity of our Hearts, whether we pray by, or without a precomposed Form. $^{108}$

We see here several features in common with Watts.

Within the Anglican sphere there was also discussion of passion in prayer. Bennet, while arguing against free prayer says:

But then, whether a Man conceives a Prayer extempore, or prays in a set Form of Words, either precompos'd, or not; 'tis certain that his Prayer cannot be acceptable to God, unless it be accompanied with such pious Affections, as are suitable to the Matter of it. ${ }^{109}$

There was a tendency though within Anglican circles to have less focus on passion in prayer. For example Henry Stebbing wrote a piece to counter enthusiasts in which he consistently downplays the need for raised passions in prayer, and is more circumspect

\footnotetext{
${ }^{107}$ Henry, Method for Prayer, Preface.

${ }^{108}$ Ibid., Preface.

${ }^{109}$ Bennet, Brief History, 11.
} 
about the role of the Holy Spirit. ${ }^{110}$ The difference in dissenting circles is illustrated by Horsley, who speaks of the superiority of heart attitude over correct words: 'we had better pray with less Proper Expressions, than with less Inward Devotion.' ${ }^{111}$

However a tendency not to emphasise passion in prayer can be seen in Dissent as well. In the Eastcheap lectures on prayer we see a representative picture of dissenting thought. As with the series of lectures on praise there is mention of the need for both understanding and appropriate passion, but there is far greater focus on simply encouraging and enforcing the duty of prayer. ${ }^{112}$

For example Reynolds, speaking on the gift, or expression, of prayer says, 'Nothing is such a furtherance to the exercise of the Gift, as an enlightened Mind, with a warm and affected Heart. ${ }^{, 13}$ But this is as far as he goes, whereas for Watts this is the starting point from which he expands. On the grace of prayer Reynolds speaks of how the affected heart of the one leading can influence those listening and of the need to warm one's heart before praying, but these are relatively minor points in his discourse, whereas for Watts they are central.

In the Baptist camp John Gill wrote on prayer including aspects of the gift, grace and spirit of prayer. ${ }^{114}$ In this there is much overlap with Watts. However there is virtually no mention of the expression or stirring of passion in prayer.

Watts then, while not unique in his view of prayer, does appear to have a more fully developed position. As with preaching he gives equal emphasis to understanding and passion, while many other works emphasise one at the expense of the other. Those that stress both usually simply state the need for understanding and right passions, and leave

\footnotetext{
${ }^{110}$ Henry Stebbing, Discourses Upon Several Subjects (London: Jonah Bowyer, 1722), 149-66.

${ }^{111}$ Horsley, Brief Reply, 2.

${ }^{112}$ Five of the six lectures address the issue of 'duty' from different perspectives.

${ }^{113}$ Reynolds, "Directions for the Gift and Grace of Prayer," in Practical Discourses Concerning the Duty of Prayer: Preach'd at the Friday Evening-Lecture in Eastcheap. By Several Ministers (London: J. Darby, 1711), 223.

${ }^{114}$ John Gill, A Discourse on Prayer (London: Aaron Ward, 1732).
} 
it at that. Watts by contrast follows these themes through in a practical guide which includes recommendations as to how to achieve this in practice, along with appropriate cautions.

We should note that one explanation is that many of these other works were focussed either on a broader overview of prayer or on particular contentious issues, such as the use of set prayers. Watts by comparison is presenting a more positive and practical work which allows him to work through his theology of reason and passion more fully. Watts makes this observation himself with regard to his own work in comparison with others. ${ }^{115}$

Gravlee and Irvine speak of Watts' Guide as a 'unique document', and refer to his 'unusual rhetoric of prayer. ${ }^{116}$ However they provide no comparative evidence to substantiate this claim. From our study we can see that Watts is easily distinguishable from both an Anglican preference for set prayers and also from a more radical focus on extempore prayer. Watts' view of 'prepared but free' prayer is similar to other moderate dissenting ministers. We may say his position is unique in how fully he develops the themes of reason, and especially passion, in practice; however the difference is that of degree, not of substance.

As with our previous topics it is also instructive to compare Watts to Puritan positions on prayer, with the usual caveats on the impossibility of comprehensive comparison. Earlier Puritans had no objection to set prayers in principle but objected to particular wording. ${ }^{117}$ However some Puritans in the seventeenth century argued for free prayer on the basis of heartfelt expression. For example:

We cannot believe that it is lawful for all of us, at all times, by submitting our selves to a Form of Prayer, to smother the Gift of Prayer, given (we

\footnotetext{
${ }^{115}$ Watts, Works, 'Prayer', Volume 3, 108.

${ }^{116}$ Gravlee and Irvine, "Rhetoric of Prayer," 463.

${ }^{117}$ Spinks, "Origins of Antipathy," 67-68.
} 
hope) to some of us, or to cool the heat and fervency of our hearts in Prayer, or the Affections of them that hear us. ${ }^{118}$

Similarly Bunyan had defined prayer in this way: 'Prayer is a sincere, sensible, affectionate outpouring of the heart or soul to God through Christ, in the strength and assistance of the holy Spirit.' 119

Bunyan goes on to expand on each element of his definition and when speaking of 'affectionate outpouring' he says, ' $\mathrm{O}$ the heat, strength, life, vigor, and affection that is in right Prayer. ${ }^{120}$ Hence the same connection between affection and freedom in prayer is made as we have seen in Watts. Later Puritans such as Richard Baxter still allowed for set forms of prayer but they were not preferred for the same reason. ${ }^{121}$

Davies says that free prayer within the Puritan camp was deeply emotional and expected 'meltings, enlargements and quickenings' in prayer, which were 'the tokens of the Spirit bearing witness within his spirit. ${ }^{122}$ Owen speaks of the work of the Spirit in this regard: 'He doth not only enable them to pray, but worketh Affections in them suitable unto what they pray about.' This can result in 'inexpressible fervency and delight', especially in the extraordinary influence of the Spirit. ${ }^{123}$

There is clearly great similarity with Watts here and we remember Watts' acknowledgement of dependence on Owen's work. However, as with preaching, Watts' emphasis on the understanding of the listener had a sharpening effect on this passionate Puritan theme. This is seen in the focus on clear and distinct ideas in language and also in Watts' concern over prolixity and complexity in prayer. He certainly warns against

\footnotetext{
${ }^{118}$ Dawbeny, Sober and Temperate Discourse, 55.

${ }^{119}$ John Bunyan, I Will Pray with the Spirit, and I Will Pray with the Understanding Also (London: Printed for the author, 1663), 4-5.

${ }^{120}$ Ibid., 12.

${ }^{121}$ Spinks, "Origins of Antipathy," 80. Also on set forms of prayer see Owen, Holy Spirit in Prayer, Chapter 7.

${ }^{122}$ Davies, Worship and Theology, Vol 2, 194. Also see Hambrick-Stowe, Practice of Piety, 104-09.

${ }^{123}$ Owen, Holy Spirit in Prayer, 88.
} 
the unhelpful effects of praying for too long - an issue most seventeenth century Puritans were unlikely to be concerned about.

Watts was also more confident about the capability of words to express the cry of the heart. This should not be overstated but, for example, Bunyan thought the best prayers had 'more groans than words', and the words they did have were 'but a lean and shallow representation of the heart, life and spirit of that Prayer., ${ }^{124}$ Owen too, while expecting expression in words as normal, allows for times when the believer 'may for the present be able only to mourn as a Dove, or to chatter as a Crane, that is, not to express the sense of their minds clearly and distinctly. ${ }^{, 125}$ Watts, while acknowledging such possibilities, would shy away from this, always wanting the sense of the mind to be expressed in clear and distinct ideas, and so speaking of how words can 'perfect' the ideas of the mind and the passions of the heart.

As we have seen before Watts also has a greater focus on the capacity of words to stir affections. While emphasising the need for the Spirit to be at work he believes that the right words arouse our affections and hence his comments on the one leading in prayer to use such expressions as will affect the hearts of those listening. This again reflects his movement away from a purely voluntarist view of the passions whereby they need to be aroused in us. ${ }^{126}$

In this greater confidence in language to express and to stir appropriate affections we can see Watts following John Wilkins to whom he acknowledges his dependence on the 'gift' or expression of prayer. ${ }^{127}$ Wilkins emphasised the need for a proper method which will 'guide and regulate our thoughts, that they may be delivered in their true place and order, without unseemly huddling, or impertinent digressions.' Wilkins warns: 'Take heed of all empty repetitions, digressions, prolixity. ${ }^{128} \mathrm{He}$ also speaks of

\footnotetext{
${ }^{124}$ Bunyan, I Will Pray with the Spirit, 53.

125 Owen, Holy Spirit in Prayer, 115.

${ }^{126}$ Chapter 3, section 6.

${ }^{127}$ We have previously noted the connection with language changes and the Royal Society: Chapter 4, section 1.1.

${ }^{128}$ Wilkins, Gift of Prayer, 38, 19.
} 
how, when passion is lacking, 'our affection should follow and be stirred up by our expressions. $^{\text {,129 }}$

The result in Watts is a greater focus on a method of prayer that can be taught, studied and grown in. While Owen and others stress the need to stir up the gift of prayer, there is far less focus on a method to learn. Hence Watts can be seen as continuing key Puritan themes of passion in prayer and the need for the work of the Spirit, but refining them with an Enlightenment view of language and reason. His position is well illustrated by the two men he acknowledges dependence on and the respective areas in which he looks to them: Owen on the spirit of prayer, and Wilkins on the gift of prayer.

Watts' desire again is that an employment of his method would play its part in a 'returning glory' to the churches. He longs for the day when:

Then shall they learn the perfection of beauty in this part of worship, when the gift and grace of prayer are happily joined in the secret pleasure and success of it, and appear before men in its full loveliness, and attractive power. Then shall religion look like itself, divine and heavenly, and shine in all the lustre it is capable of here on earth. ${ }^{130}$

\footnotetext{
${ }^{129}$ Ibid., 15.

${ }^{130}$ Watts, Works, 'Prayer', Volume 3, 197.
} 


\section{Chapter 7 Conclusion}

\section{Summary of findings}

We noted in the introduction that given his significance Watts is an under-studied figure. This is so in several ways. First, there has been little attempt to examine Watts' overall theology or identify central themes within his thought. Secondly, Watts' practical works have rarely been connected with his underlying theology resulting in a lack of a coherent picture. Thirdly, while being identified as of Puritan heritage there has been little analysis of how Watts departs from or continues Puritan theology and practice.

In this study we have focussed on the first and second of these areas: we have identified key themes in Watts' thought and have linked his practical works with these underlying themes so demonstrating a coherence and unity across his works. In doing so we have had occasion to compare him with both his contemporaries and his Puritan predecessors and hence have made some comment on the third area. As we have said however, that comparison must be seen as limited and illustrative.

In concluding we begin with a summary of what we have found. Watts gladly bore the name of Puritan, frequently referenced Puritan authors and was keen to be seen in continuity with them. However he was also acutely aware of the intellectual changes of his day and was equally keen to take on board the best of them. Hence he becomes a modified or 'Enlightenment' Puritan.

We have seen that Watts significantly absorbed Enlightenment thought on the role of reason, especially showing dependence on John Locke. However he retains significant elements of traditional Puritan thought in the limits placed on reason. In particular he views reason as fatally weakened by sin. The source of this weakness is located in the overthrow of right reason by sinful passions. Despite this Watts still has a high view of reason. The overall result is an uneasy tension in Watts: he wishes to defend orthodoxy by the principles of rationality so esteemed in his day, but still to carve out space for 
doctrine 'above reason'. In his resultant position he appears to continue the trajectory established by later Puritan figures such as Baxter and Howe.

Watts also continued the Puritan theme of experiential religion and seeks to justify that as reasonable. Indeed he utilises the empiricism of Locke in saying that the experience of the believer provides rational evidence of the miracle of conversion. We saw that Watts shared in the more positive view of the passions that arose in the late seventeenth and early eighteenth century, and he ties this to a more precise religious psychology. Hence while Watts continues a Puritan focus on affective piety his tone with regard to the passions became overall more positive than many Puritans, and he moved away from a purely voluntaristic view of the passions towards a three-faculty position.

Compared with many of his contemporaries however Watts retains a more conservative theological foundation. This takes seriously the corrupting influence of sin on the passions which Watts sees as lying at the heart of the dynamic of sin. This means that his positive place for the passions in his religious psychology is combined with more traditional elements such as the need for renewal and sanctification by the Holy Spirit and the pre-eminence of the love of God in guiding the passions.

We have then focused on an examination of how Watts' position on reason and passion informed and guided his attempts to revive religion. We have done so in three areas: preaching, praise and prayer. We saw that his views on these areas drew explicitly on elements of Lockean thought such as clear and distinct ideas linked to comprehensibility. This resulted in a simplifying of Puritan practice usually linked to the understanding of the Christian worshipper. There was also a greater desire to draw on the arguments of reason as well as revelation. Watts' view of the relationship between reason and revelation is also very much in play in these practical areas.

In each of preaching, praise and prayer there is also the desire for stimulation and expression of passion in very deliberate ways. These show the subtle but significant move Watts made towards the newer theories of the passions. This is then linked with the use of language and the passion of the speaker or writer to stimulate passion in others. 
It is not suggested that every point of Watts' position on reason and passion is demonstrated equally in his practical works, but the overall pattern is clear. In this we have identified underlying seams of Watts' thought and demonstrated the coherence and consistency of his position. It is not claimed that this study has relocated Watts and his thought but rather that we have located him more precisely.

\title{
2. Comparison with other presentations of Watts
}

This more carefully drawn picture of Watts allows a critique of views of Watts already proposed. Davis' view of Watts is that of a 'Puritan rebel'. ${ }^{1}$ He describes Watts' inheritance of Puritan tradition and argues that he quietly innovates on it rather than passively accepting it. ${ }^{2}$ Davis sees the innovations as lying primarily in areas of poetry, hymnody and education which we have previously noted. However with regard to his more general religious works Davis describes Watts as inconsistent because he was an 'ingrained compromiser'. His summary includes this significant paragraph:

\begin{abstract}
Watts accepted Locke's philosophy, but he also clung to the theory of "innate ideas"; he wrote a Guide to Prayer to tone down dissenter enthusiasm in prayer, but he published An Exhortation to Ministers to arouse more warmth in nonconformist preaching; he rejected the Trinity of the Athanasian Creed because it was illogical, yet he refused to be classed with the Unitarians; he exalted reason in his non-religious essays and depreciated the sufficiency of reason in the religious; he has the usual Neoclassic horror of enthusiasm, but he spent a lifetime trying to infuse it into the religion of his age; he believed in the certain election of a chosen few, but at the same time he insisted that all men have free will. ${ }^{3}$
\end{abstract}

While there is some truth in Watts' tendency to compromise we have hopefully elucidated a view of Watts' thought that explains many of these 'inconsistencies'. We can go through them in turn.

\footnotetext{
${ }^{1}$ Davis, "Puritan Rebel."

${ }^{2}$ Davis, Watts, 218-22.

${ }^{3}$ Ibid., 222.
} 
We have seen that it is his view of reason which results in tensions over theological formulations such as the trinity and election. Thus this was not so much a compromise between different theological positions as struggling to reconcile what for Watts were two equally important principles - that of submitting to revelation and the 'reasonableness' of doctrine. We have seen that Watts did not simply 'accept' Locke's philosophy, but modified it at significant points and in significant ways. He also certainly did not cling to the theory of innate ideas.

In particular we have seen that it is his view of reason and passion together which explain so much of his position. Taken as a whole there is not an inconsistent view of reason in different works but rather a nuanced view applied to different areas. Neither is there an inconsistency in his view of the passions but rather a careful combining of different principles and keen awareness of the lurking dangers. Hence his Guide to Prayer and his Exhortation to Ministers are not written, as Davis suggests, to 'tone down dissenter enthusiasm', and 'arouse more warmth' respectively. Rather they each display the same desire for clear reason and a positive place for passion, applied to different topics and situations.

Similarly he did not have a 'horror' of enthusiasm but then try to instil it into the religion of his day. Rather he had a carefully developed theory of the passions which were positive about their use and argued for their stimulation, but still believed they should be guided by reason and knew that they could be misused.

Davis' summary of Watts as an 'ingrained compromiser' and so inconsistent, has made its way into the literature as one of the dominant views of Watts. But that is not to read Watts on his own terms. We have shown that while Watts certainly had a tendency for the compromising middle way, he was not necessarily inconsistent as a result. Rather more careful analysis shows a remarkable consistency of position.

We can respond in a similar vein to Hoyles' analysis. Hoyles says of Watts: 'His constant preoccupation is to establish an incontrovertible via media, in which the 
opinions of all men may unite. ${ }^{4}$ So for example in preaching Watts called for 'via media between puritan and polite, eschewing the extremes of both. ${ }^{5}$ Again Hoyles cites Watts' desire to speak of the inward witness of the faith as evidence in the heart, but says his via media tendency means he has to qualify this by saying that it is also an evidence supported by reason. ${ }^{6}$ In this 'via media' position Hoyles presents Watts as a typical example of the English Enlightenment. Similarly Davis had referred to Watts' position on some topics as a 'typical Neo-classical compromise.'7

There is clearly truth here which we have already noted in our discussion in the previous chapters. Rivers too shows how Watts acts a reconciler who moves opposing parties to a middle ground position. ${ }^{8}$ However our analysis shows that we can go beyond a simple compromising middle way as a description of the course Watts steered. Rather we have seen that it is Watts' moderated Puritan position on reason and passion that explains the particular middle way he took. This means that in variety of areas we have noted he steers to the left or the right rather than simply seeking compromise.

So for example in his view of preaching there is a desire to combine Puritan elements of content, appeal to the heart and basic structure with neo-classical simplicity and ease of understanding. This is not simply a middle way but a combining of particular elements for particular reasons and purposes. In his view of praise there is a distinct move away from the majority Puritan position specifically to allow greater understanding so as to achieve appropriate stimulation and expression of the passions. In his view of prayer we do see a middle way between set prayers and extempore prayer. However Watts' method of 'free but conceived' prayer is guided by his desire for clear and well ordered content plus his concern for the expression of passion by the speaker and stimulation of passion in the hearers. Hence the path taken in each case is guided by a judicious combining of reason and passion, rather than simple compromise.

\footnotetext{
${ }^{4}$ Hoyles, Waning of the Renaissance, 153.

5 Ibid., 154.

${ }^{6}$ Ibid., 187-88.

${ }^{7}$ Davis, Watts, 142.

${ }^{8}$ Rivers, Reason, Grace and Sentiment, Vol 1, 179-80.
} 
We should also note that throughout these areas there is little movement from a common Puritan position in the view of the work of Spirit. Hence Watts' underlying theological position is much more in play than simply being a typical Enlightenment figure seeking a central position around which all may unite. Indeed at moments Watts knows he is siding with a particular group such as the Puritans and so will be scorned by the polite groups of his day. If he was aiming at a purely via media position around which the majority could agree he would have ended up in a different place. In particular there would have been far less focus on the need for sanctified passions, experience of God and the work of the Spirit.

We can make a similar response with regard to Sharon Achinstein's conclusions on Watts' hymn writing. She observes Watts' shunning of the Revolutionary hymns of the previous century and attributes this to his rejection of revolutionary enthusiasm and an embrace of universal, rational truths. This is seen as part of the arrival of 'Rational Dissent'. ${ }^{9}$ Hence Watts' hymn writing is explained by placing him in the centre of a cultural stream.

Again there is truth in this but we must note that these are not the reasons stated by Watts for his style of hymn writing. He does indeed wish to distance himself from revolutionary enthusiasm, and he does choose to avoid contentious subjects. However his updating of the psalms is expressly driven by his desire for the Christian believer to express his or her passion in words that they understand. This then finds its place in his desire for the reform and revival of the church. Hence again not enough attention is paid to Watts' underlying theology and stated purpose.

What we have seen is something of a confirmation and expansion of Rivers' presentation of Watts. Rivers sees Watts as mediating Puritan theology particularly flowing from Baxter. Watts, along with Doddridge, is seen as trying to:

\footnotetext{
${ }^{9}$ Achinstein, Literature and Dissent, 240-41.
} 
...balance the rational and evangelical tendencies of dissent and to transmit the attitudes and values of their puritan and nonconformist fathers, modified to suit the changes in the social and intellectual climate, to the new generation of dissenters. ${ }^{10}$

We have interacted with elements of Rivers' thought in the preceding chapters. In summary we have seen a confirmation of her general thesis with a sharpening and expansion in a number of areas. In particular we have clarified the extent to which Watts agrees and disagrees with Locke on the role of reason, the way in which the passions are both encouraged and guarded against, and have seen Watts' move away from a traditional Puritan voluntaristic view of the passions. We have also then combined Watts' view of reason and passion more thoroughly and seen how they play out in his view of the revival of religion.

We can make a further comment on Rivers' presentation of Watts. It reflects a common view in the secondary literature that Watts (and Doddridge) act as moderates who bridge the gap between the rationalist and orthodox wings of dissent. ${ }^{11}$ That gap is seen as ever widening through the eighteenth century. Hence Watts is seen in the above quote as someone trying to balance between rational and evangelical poles. This is clearly the case: we have seen Watts wrestling with the tensions introduced by the rise of rationalism and attempting to articulate orthodoxy in terms of reason.

However the danger of this analysis is that Watts is seen as someone unwillingly pulled in two directions between the older orthodoxy and newer rationalism. He is seen as stretched in this way because of the intellectual streams of his day. His position then is seen as inherently unstable. Hence Watts is viewed as one of the last to try to hold together incompatible tendencies which would inevitably be forced apart.

While we may well have our own view on the incompatibility of orthodoxy and rationalism we must understand is that this is not how Watts viewed himself or his situation. Rather we have seen that he welcomed progress in the use of reason and

\footnotetext{
${ }^{10}$ Rivers, Reason, Grace and Sentiment, Vol 1, 168.

${ }^{11}$ Ibid., 165-68.
} 
willingly incorporated it into his theological and practical works. Similarly he embraced new thinking on the passions and utilized its insights.

Hence rather than someone unwillingly pulled in two directions we have seen that Watts saw himself as self-consciously forging a new path. He believed that there was a clear way ahead which combined the best of Puritan and Enlightenment thought. Indeed he thought that this path led to the revival of religion not simply the preserving of it. The mechanisms of this revival, as we have seen, are cast in clear terms in Watts' practical works, and, as we have argued, these are dependent on his foundational view of reason and passion.

Hence we do not disagree with previous presentations of Watts' moderate position and attempt to 'balance' different elements. But a much more positive note must be added: Watts believed a bright future was possible and was trying to lead Dissent down this road. It was a road to revival that depended on his modified Puritan position on reason and passion implemented in preaching, praise and prayer. ${ }^{12}$

\section{Watts' position in his day}

Watts' modified Puritan position gave him a noticeable and interesting place within his day. Compared to those who simply continued traditional Puritan theology Watts was able to provide a more effective apologetic. His engagement with the cultural thought of his day meant that he was a defender of the faith for believers and an evangelist to those outside the fold. He took intellectual changes seriously, appropriated elements of them, and sought to present the faith on their terms. His attempts here did concede significant ground to a rationalist approach, so much so that Watts can be seen as an early stepping stone towards a fuller rationalistic theology. We see indications of this in the tensions and uncertainties in his theological position, especially on the trinity.

\footnotetext{
${ }^{12}$ For a similar discussion on Philip Doddridge see Robert Strivens, "The Thought of Philip Doddridge in the Context of Early Eighteenth-Century Dissent " (University of Stirling, 2011).
} 
In particular Watts gives a high place to reason such that he speaks readily of the light of revelation and the light of nature as parallel and equal. As we have seen this was standard among ministers of the day. Within this Watts still guards the superiority of revelation, and argues for this superiority on the basis of reason. This position of course was vulnerable because it was conducted on the playing field of reason, and having moved the location of the discussion it was all too easy for reason to take over the game. This is the common move we observe through the first half of the eighteenth century in rationalistic dissent.

Watts himself however guarded against this in two ways. First he retains a very strong position on the blinding nature of sin. We have noted certain tensions here. He would like to believe that unprejudiced investigation will always lead to orthodoxy; and yet thinks that sin always prejudices such investigation. He would like to explain every Christian doctrine on the basis of reason, and so defend the faith, but finds some doctrines too much of a mystery to do so within the bounds of orthodoxy. Despite this however Watts is insistent that reason is overthrown by sin and so is ultimately blind.

Secondly Watts retains a key place for the experience of the believer. The knowledge of God in the heart, the testimony of the Spirit, the miracle of new life, and the harmony of realigned faculties all reassure the believer. In this point especially Watts creates an anchor against the insipient rationalism in his thought. While he defends all these truths again as 'reasonable' he is drawing on an existential basis less vulnerable to rationalist attack. It is this element that later becomes dominant in the evangelical revivals.

With regard to passion while Watts agrees with the moral sentimentalists on the presence of innately benevolent passions he locates them within a traditional theological position. This means he avoids the instability that sentimentalism produced: the seeking of a foundation for morality and so trying to find in moral sense a faculty that combined both feeling and reason. ${ }^{13}$ Watts' acceptance of moral sentiment then does not lead to the overthrow of reason such as is later seen in David Hume.

\footnotetext{
${ }^{13}$ Bell, Sentimentalism, 18-39.
} 
It would be worthy of further study to compare Watts to figures such as George Whitefield, John Wesley, and Jonathan Edwards. For example in Edwards we see the continuation of a more traditional Puritan position than in Watts, whereas in Wesley we see the rise of a pietism more emotional in nature than in Watts. The comparison with Edwards may prove particularly instructive as both he and Watts interacted with Enlightenment thought on reason and passion and produced distinctive philosophical and practical positions as a result. On passion for example Edwards continues the Augustinian voluntarism of the seventeenth century puritans. ${ }^{14}$ Watts, by contrast, has a less clear cut view of human psychology such that he can separate the will and passions rather than equating them. However there is still great overlap between their respective positions, both speaking of the spiritual taste that the Spirit gives, the pre-eminence of the love of God which will drive the other passions, and the need for stimulation and expression of passion in vital religion.

It may also be worthwhile to explore Watts' modification of Puritan thought more precisely. The comparisons made here are illustrative soundings which have outlined broad areas. However examination of Watts' position compared to that of John Owen or Richard Baxter in particular would prove illuminating.

In conclusion we have seen that Watts argued for a modified Puritan position on the role of reason and passion. This laid the foundation for his view of the revival of religion in his day as seen in practical works on preaching, praise and prayer. We have not relocated Watts compared to the secondary literature but we have located him far more precisely than has been previously done. We have also seen he holds a far more consistent and thought through position than has previously been acknowledged. As such we can appreciate the distinctive and significant role he played in the first half of the eighteenth century and beyond.

\footnotetext{
${ }^{14}$ Fiering, Moral Philosophy, 138.
} 


\section{Bibliography}

Aarsleff, Hans. "Philosophy of Language." In The Cambridge History of EighteenthCentury Philosophy, edited by Knud Haakonssen. Cambridge: Cambridge University Press, 2006.

Abney, Lady Mary. "Sermon Notes 1722-1723." In James Marshall and Marie-Louise Osborn Collection. New Haven: Beinecke Rare Book and Manuscript Library, Yale University.

Achinstein, Sharon. Literature and Dissent in Milton's England. Cambridge: Cambridge University Press, 2003.

Arnold, Richard. The English Hymn: Studies in a Genre. New York: P. Lang, 1995.

Ashworth, Caleb. Reflections on the Fall of a Great Man. A Sermon Preached to a Congregation of Protestant Dissenters at Daventry in Northamptonshire, On the Ocassion of the Death of the Late Reverend Isaac Watts D.D. London: J. Waugh, 1749.

Augustine, Saint. The City of God Against the Pagans. Edited by R. W. Dyson. Cambridge: Cambridge University Press, 1998.

Ayers, Michael. Locke. London: Routledge, 1991.

Bailey, Albert Edward. The Gospel in Hymns: Backgrounds and Interpretations. New York: Charles Scribner's Sons, 1950.

Barry, James. A Help to Prayer: Or, a Serious and an Impartial Discourse of Right Prayer. London: John Marshall, 1701.

Barton, William. A Century Of Select Hymns. London: Francis Eglesfield, and Thomas Underhill, 1659.

Bates, William. A Funeral-Sermon for the Reverend, Holy and Excellent Divine, Mr. Richard Baxter. London: Brab. Aylmer, 1692.

Baxter, Richard. A Christian Directory. London: Robert White, 1673.

Baxter, Richard. Englands Warning-Piece. London: J. Conyers, 1678.

Baxter, Richard. Paraphrase on the Psalms of David. London: Thomas Parkhurst, 1692.

Baxter, Richard. Poetical Fragments: Heart-Imployment with God and It Self. London: T. Snowden, 1681.

Baxter, Richard. The Reasons of the Christian Religion. London: R. White, 1667.

Baxter, Richard. The Reformed Pastor. Edinburgh: Banner of Truth Trust, 1974.

Baxter, Richard. The Saints Everlasting Rest. London: Rob. White, 1650.

Bebbington, D. W. Evangelicalism in Modern Britain: A History from the 1730's to the 1980's. London: Unwin Hyman, 1989.

Bell, Michael. Sentimentalism, Ethics and the Culture of Feeling. Basingstoke: Palgrave, 2000.

Bennet, Thomas. A Brief History of the Joint Use of Precompos'd Set Forms of Prayer. Cambridge: Edmund Jeffery, 1708.

Benson, Louis Fitzgerald. The English Hymn: Its Development and Use in Worship. New York: Hodder and Stoughton, 1915.

Bernard, Richard. The Faithfull Shepheard: or, The Shepheards Faithfulnesse. London Arnold Hatfield, 1607.

Bishop, Selma L. Isaac Watts: Hymns and Spiritual Songs, 1707-1748. With a Study of Early Eighteenth-Century Language Changes. London: Faith Press, 1962. 
Blackmore, Richard Sir. The Accomplished Preacher: or, An Essay upon Divine Eloquence. London: J. Downing, 1731.

Bolam, Charles Gordon, Jeremy Goring, Harry Lismer Short, and Roger Patrick David Thomas. The English Presbyterians: From Elizabethan Puritanism to Modern Unitarianism. London: George Allen \& Unwin, 1968.

Bourn, Samuel. The Christian Family Prayer Book: or, Family Prayers for Morning and Evening; with a Variety of Occasional Forms. Recommended by Dr I. Watts. London: Richard Ford, 1737.

Boyle, Robert. A Discourse of Things Above Reason. London: Jonathan Robinson, 1681.

Boyse, J. Sacramental Hymms. Dublin: Thomas Parkhurst, 1693.

Bradbury, Thomas. The Nature of Faith. London: John Clark, 1721.

Bradbury, Thomas. The Necessity of Contending for Revealed Religion. London: $\mathrm{H}$. Woodfall, 1720.

Bradbury, Thomas. The Popish Doctrine of Justification by Works. London: J. Oswald, 1735.

Bradley, James "The Changing Shape of Religious Ideas in Enlightened England." In Seeing Things Their Way: Intellectual History and the Return of Religion, edited by Alister Chapman, John Coffey and Brad S. Gregory. Notre Dame, Ind.: University of Notre Dame Press, 2009.

Bragge, Francis. A Practical Treatise of the Regulation of the Passions. London: John Wyat, 1708.

Branch, Lori. Rituals of Spontaneity: Sentiment and Secularism from Free Prayer to Wordsworth. Waco: Baylor University Press, 2006.

Bremer, Francis J. Shaping New Englands: Puritan Clergymen in Seventeenth Century England and New England. New York: Maxwell Macmillan International, 1994.

Bremer, Francis, and Ellen Rydell. "Performance art? Puritans in the pulpit." History Today 45, no. 9 (1995): 50.

Brinton, Alan. "The Passions as Subject Matter in Early Eighteenth-Century British Sermons." Rhetorica 10, no. 1 (1992): 51-69.

Brooks, G. P. "Mental Improvement and Vital Piety: Isaac Watts and the Benefits of Astronomical Study." Dalhousie Review 65, no. 4 (1985): 551-64.

Brown, Raymond. "Baptist Preaching in Early 18th Century England." Baptist Quarterly 31, no. 1 (1985): 4-22.

Bunyan, John. I Will Pray with the Spirit, and I Will Pray with the Understanding Also. London: Printed for the author, 1663.

Burscough, William. The Duty of Praise and Thanksgiving. London: S. Crouch and T. Childe, 1715.

Butler, Joseph. The Analogy of Religion, Natural and Revealed, to the Constitution and Course of Nature. London: James, John and Paul Knapton, 1736.

Butler, Joseph. Fifteen Sermons Preached at the Rolls Chapel. London: W. Botham, 1729.

Campbell, Ted. The Religion of the Heart: A Study of European Religious Life in the Seventeenth and Eighteenth Centuries. Columbia: University of South Carolina Press, 1991.

Cavanaugh, William T. "The Invention of Fanaticism." Modern Theology 27, no. 2 (2011): 226-37.

Chan, Bruce Andrew. "Isaac Watts's Psalms of David Imitated in the Language of the New Testament." University of London, 1968. 
Chapman, Alister, John Coffey, and Brad S. Gregory. Seeing Things Their Way: Intellectual History and the Return of Religion. Notre Dame, Ind.: University of Notre Dame Press, 2009.

Chappell, V. C. "John Locke on the Intellectual Basis of Sin." Journal of the History of Philosophy 32, no. 2 (1994): 197-207.

Chappell, Vere. "Locke's Theory of Ideas." In The Cambridge Companion to Locke, edited by Vere Chappell. New York: Cambridge University Press, 1994.

Charnock, Stephen. Several Discourses Upon the Existence and Attributes of God. London: D. Newman, 1682.

Cherry, Conrad. The Theology of Jonathan Edwards: A Reappraisal. Gardan City, N.Y.: Doubleday, 1966.

Clark, J. C. D. English Society, 1660-1832: Religion, Ideology and Politics during the Ancien Regime. Cambridge: Cambridge University Press, 2000.

Clarke, Elizabeth. "Hymns, Psalms, and Controversy in the Seventeenth Century." In Dissenting Praise: Religious Dissent and the Hymn in England and Wales, edited by Isabel Rivers and David L. Wykes. Oxford: Oxford University Press, 2011.

Clarke, John. Holy Oyle for the Lampes of the Sanctuarie. London: Aug. Mathewes, 1630.

Clarke, Samuel. A Discourse Concerning the Being and Attributes of God, the Obligations of Natural Religion, and the Truth and Certainty of the Christian Revelation. London: W. Botham, 1728.

Clarke, Samuel. A Discourse Concerning the Unchangeable Obligations of Natural Religion, and the Truth and Certainty of the Christian Revelation. London: W. Botham, 1706.

Clarke, Samuel. The Government of Passion. London: Will. Botham, 1711.

Clifford, M. A Treatise of Humane Reason. London: Henry Brome, 1675.

Coffey, J. "Puritanism, Evangelicalism and the Early Protestant Tradition." In The Emergence of Evangelicalism: Exploring Historical Continuities, edited by Michael A. G. Haykin and Kenneth J. Stewart. Nottingham: Apollos, 2008.

Coffey, John. "Puritan Legacies." In The Cambridge Companion to Puritanism edited by John Coffey and Paul Chang-Ha Lim, xi, 385 p. Cambridge: Cambridge University Press, 2008.

Coffey, John, and Paul Chang-Ha Lim. "Introduction." In The Cambridge Companion to Puritanism, edited by John Coffey and Paul Chang-Ha Lim, xi, 385 p. Cambridge: Cambridge University Press, 2008.

Cohen, Charles Lloyd. God's Caress: The Psychology of Puritan Religious Experience. Oxford: Oxford University Press, 1986.

Collins, Anthony. A Discourse of Free-Thinking. London, 1713.

Compton, Henry. Whether Set-Forms of Prayer be not Very Necessary in the Publick Worship of God. London: Benj. Motte, 1707.

Cook, Harold J. "Body and Passions: Materialism and the Early Modern State." Osiris 17 (2002): 25-48.

Corrigan, John. "'Habits from the Heart": The American Enlightenment and Religious Ideas about Emotion and Habit." The Journal of Religion 73, no. 2 (1993): 18399.

Cousland, Kenneth Harrington. "The Significance of Isaac Watts in the Development of Hymnody." Church History 17, no. 4 (1948): 287-98. 
Cragg, G. R. From Puritanism to the Age of Reason: A Study of Changes in Religious Thought within the Church of England 1660 - 1700. Cambridge: Cambridge University Press, 1966.

Cragg, Gerald Robertson. Reason and Authority in the Eighteenth Century. Cambridge: Cambridge University Press, 1964.

Crockett, Bryan. "The Act of Preaching and the Art of Prophesying." The Sewanee Review 105, no. 1 (1997): 39-52.

Curate, Jacob. The Scotch Presbyterian Eloquence. London Randal Taylor, 1692.

Dargan, Edwin Charles. A History of Preaching. Vol. 1. Grand Rapids: Baker Book House, 1954.

Darwall, Stephen. "The Foundations of Morality: Virtue, Law, and Obligation." In The Cambridge Companion to Early Modern Philosophy, edited by Donald Rutherford. Cambridge: Cambridge University Press, 2006.

Davidson, Bruce W. "The four faces of self-love in the theology of Jonathan Edwards." Journal of the Evangelical Theology Society 51, no. 1 (2008).

Davie, Donald. The Eighteenth-Century Hymn in England. Cambridge: Cambridge University Press, 1993.

Davie, Donald. A Gathered Church: The Literature of the English Dissenting Interest, 1700-1930. London: Routledge \& K. Paul, 1978.

Davie, Donald, and Robert Murrell Stevenson. English Hymnology in the Eighteenth Century. Los Angeles: William Andrews Clark Memorial Library, 1980.

Davies, Horton. Worship and Theology in England: Volume 2, from Andrewes to Baxter and Fox, 1603-1690. Princeton: Princeton University Press, 1975.

Davies, Horton. Worship and Theology in England: Volume 3, From Watts and Wesley to Maurice, 1690-1850. Princeton: Princeton University Press, 1961.

Davies, Horton. The Worship of the English Puritans. Glasgow: Robert Maclehouse and Co., 1948.

Davis, Arthur Paul. Isaac Watts: His Life and Works. London: Independant Press, 1948.

Davis, Arthur Paul. "Isaac Watts: Late Puritan Rebel." Journal of Religious Thought 13, no. 2 (1956): 123-30.

Davis, Richard. Hymns Composed on Several Subjects. London: W. Marshall and H. Bernard, 1694.

Dawbeny, Henry. A Sober and Temperate Discourse, Concerning the Interest of Words in Prayer, the Just Antiquity and Pedigree of Liturgies, or Forms of Prayer in Churches. London Printed for W.A., 1661.

Deconinck-Brossard, Francoise. "The Art of Preaching." In Preaching, Sermon and Cultural Change in the Long Eighteenth Century, edited by Joris van Eijnatten. Leiden: Brill, 2009.

Deconinck-Brossard, Francoise. "Eighteenth-Century Sermons and the Age." In Crown and Mitre: Religion and Society in Northern Europe Since the Reformation, 105-21. Woodbridge: Boydell Press, 1993.

Defoe, Daniel. The Present State of the Parties in Great Britain: Particularly an Enquiry into the State of the Dissenters in England. London: J. Baker, 1712.

DeSilva, David A. "The Pattern for Preachers: Archbishop John Tillotson and the Reform of Ecclesiastical Oratory in the Seventeenth Century." Anglican \& Episcopal History 75, no. 3 (2006): 368-400.

A Directory for Publique Worship of God. London: G.M. and I.F., 1645.

Dixon, Thomas. From Passions to Emotions: The Creation of a Secular Psychological Category. Cambridge: Cambridge University Press, 2003.

Dixon, Thomas. "Revolting Passions." Modern Theology 27, no. 2 (2011): 298-312. 
Dorrington, Theophilus. A Discourse on Singing in the Worship of God. London: H. Clark, 1704.

Dorrington, Theophilus. The Plain Man's Gift of Prayer: Shewing What it is, and Directing the Use of it in his Family. London: John Wyat, 1703.

Downey, James. The Eighteenth Century Pulpit: A Study of the Sermons of Butler, Berkeley, Secker, Sterne, Whitefield and Wesley. Oxford: Clarendon Press, 1969.

Dryden, Dennis. A Collection of Divine Hymns and Poems on Several Occasions. London: J. Baker, 1709.

Edwards, John. The Preacher. A Discourse, Shewing, What are the Particular Offices and Employments of those of that Character in the Church. London: J.

Robinson, J. Lawrence, and J. Wyat, 1705.

Edwards, Jonathan. Freedom of the Will. Edited by Paul Ramsey. New Haven: Yale University Press, 1957.

Edwards, Jonathan. Religious Affections. Edited by John E. Smith. New Haven: Yale University Press, 1959.

Edwards Jr., O. C. "Varieties of Sermon: A Survey of Preaching in the Long Eighteenth Century." In Preaching, Sermon and Cultural Change in the Long Eighteenth Century, edited by Joris van Eijnatten. Leiden: Brill, 2009.

Edwards, O. C. A History of Preaching. Nashville, Tenn.: Abingdon, 2004.

Edwards, Thomas. A Discourse of Praying in the Spirit: or Against Extemporary Prayer. London: Robert Clavel, 1703.

England, Martha Winburn. "Emily Dickinson and Isaac Watts: Puritan Hymnodists." Bulletin of the New York Public Library (1965): 83.

Escott, Harry. Isaac Watts, Hymnographer: A Study of the Beginnings, Development and Philosophy of the English Hymn. London: Independent Press, 1962.

Fairchild, Hoxie Neale. Religious Trends in English Poetry. New York: Columbia University Press, 1939.

Fenner, William. The Soules Looking-Glasse Lively Representing its Estate before God. Edited by Edmund Calamy. Cambridge: Roger Daniel, 1640.

Fenner, William. A Treatise of the Affections. London: E.G., 1641.

Ferrell, Lori Anne, and Peter E. McCullough. "Revising the Study of the English Sermon." In The English Sermon Revised: Religion, Literature and History, 1600-1750, edited by Lori Anne Ferrell and Peter E. McCullough. Manchester: Manchester University Press, 2001.

Field, David. Rigide Calvinisme in a Softer Dresse: The Moderate Presbyterianism of John Howe (1630-1705). Edinburgh: Rutherford House, 2004.

Fiering, Norman. Jonathan Edwards's Moral Thought and its British Context. Chapel Hill: University of North Carolina Press, 1981.

Fiering, Norman. Moral Philosophy at Seventeenth-Century Harvard: A Discipline in Transition. Chapel Hill: University of North Carolina Press, 1981.

Fiering, Norman S. "Irresistible Compassion: An Aspect of Eighteenth-Century Sympathy and Humanitarianism." Journal of the History of Ideas 37, no. 2 (1976): 195-218.

Figures, Joseph. "Isaac Watts and his Position in the Eighteenth Century." Congregational Quarterly 35 (1957): 341-56.

Fincham, Kenneth, and Nicholas Tyacke. Altars Restored: The Changing Face of English Religious Worship, 1547-c.1700. Oxford: Oxford University Press, 2007.

Flavel, John. A Saint Indeed: or The Great Work of a Christian, Opened and Pressed; from Prov. 4. 23. London: W.R., 1668. 
Fleming, Robert. A Persuasive to Moderate all Affections to Worldly Objects. London: Andrew Bell, 1716.

Fountain, David G. Isaac Watts Remembered. Harpenden: Gospel Standard Baptist Trust, 1974.

France, Peter. "Rhetoric." In The Cambridge History of Eighteenth-Century Philosophy, edited by Knud Haakonssen. Cambridge: Cambridge University Press, 2006.

Garrett, Aaron. "Seventeenth-Century Moral Philosophy: Self-Help, Self-Knowledge and the Devil's Mountain!" In The Oxford Handbook of the History of Ethics, edited by Roger Crisp. Oxford Oxford University Press, forthcoming.

Garrett, Cynthia. "The Rhetoric of Supplication: Prayer Theory in Seventeenth-Century England." Renaissance Quarterly 46, no. 2 (1993): 328.

Gascoigne, John. "Science, Religion and the Foundation of Morality." Enlightenment and Dissent 17 (1998).

Gatiss, Lee. For Us and Our Salvation: 'Limited Atonement' in the Bible, Doctrine, History and Ministry. London: Latimer Trust, 2012.

Gerrish, A. B. "Natural and Revealed Religion." In The Cambridge History of Eighteenth-Century Philosophy, edited by Knud Haakonssen. Cambridge: Cambridge University Press, 2006.

Gibbons, Thomas D. D. Memoirs of Isaac Watts: London, 1780.

Gibson, Bishop. The Bishop of London's Pastoral Letter to the People of his Diocese. Dublin: J. Watts, 1728.

Gibson, Edmund. Directions given by Edmund Lord Bishop of London to the Clergy of his Diocese. London: S. Buckley, 1724.

Gibson, Edmund. Family-Devotion: or, an Exhortation to Morning and Evening Prayer in Families. London: 1705.

Gill, John. The Cause of God and Truth. London: Aaron Ward, 1735-38.

Gill, John. A Discourse on Prayer. London: Aaron Ward, 1732.

Gill, John. Levi's Urim and Thummim found with Christ. London: Aaron Ward, 1725.

Gillingham, S. E. Psalms through the Centuries, Blackwell Bible commentaries. Oxford: Blackwell 2008.

Gillman, Frederick John. The Evolution of the English Hymn. London: Allen and Unwin, 1927.

Goldsmith, Oliver. Collected Works. Edited by A. Friedman. Oxford: Clarendon Press, 1966.

Gordon, Alexander. Addresses, Biographical and Historical. London: The Lindsey Press, 1922.

Goring, Paul. "Anglicanism, Enthusiasm and Quixotism: Preaching and Politeness in Mid-Eighteenth Century Literature." Literature and Theology 15, no. 4 (2001): 326-41.

Goring, Paul. The Rhetoric of Sensibility in Eighteenth-Century Culture. Cambridge: Cambridge University Press, 2005.

Gough, Strickland. An Enquiry into the Causes of the Decay of the Dissenting Interest. London: J. Roberts, 1730.

Gravlee, G. Jack, and James R. Irvine. "Watts' Dissenting Rhetoric of Prayer." Quarterly Journal of Speech 59, no. 4 (1973): 463.

Green, Ian M. ""All People that on Earth do Dwell. Sing to the Lord with Cheerful Voice": Protestantism and Music in Early Modern England." In Christianity and Community in the West: Essays for John Bossy, edited by Simon Ditchfield. Aldershot: Ashgate, 2001. 
Green, Ian M. "New for Old? Clerical and Lay Attitudes to Domestic Prayer in Early Modern England." Reformation and Renaissance Review 10, no. 2 (2008).

Gregory, Jeremy. "'For All Sorts and Conditions of Men': The Social Life of the Book of Common Prayer during the Long Eighteenth Century: or, Bringing the History of Religion and Social History Together." Social History 34, no. 1 (2009): 29-54.

Grove, Henry. The Spectator, 1 September 1714.

Gunn, Scott A. "We Have Sat Out Ye Hearing of a Sermon": Manuscript Sermons in the James M. and Marie-Louise Osborn Collection." Yale University Library Gazette 71, no. 3/4 (1997): 140-54.

Halyburton, Thomas. Memoirs of the Life of the Reverend, Learned and Pious Mr. Thomas Halyburton. With a large Recommendatory Epistle by I. Watts. London: R. Cruttenden, 1718.

Halyburton, Thomas. Natural Religion Insufficient; and Reveal'd Necessary to Man's Happiness in his Present State. Edinburgh: Andrew Anderson, 1714.

Hambrick-Stowe, Charles E. The Practice of Piety: Puritan Devotional Disciplines in Seventeenth-Century New England. Chapel Hill [N.C.]: University of North Carolina Press, 1982.

Harrison, Peter. 'Religion' and the Religions in the English Enlightenment. Cambridge: Cambridge University Press, 1990.

Harvey, F. Brompton. "The Two Isaacs: Newton 1642-1727; Watts 1674-1748." London Quarterly and Holborn Review 174 (1949): 126-36.

Haykin, Michael A. G. "The Undivided Three: The Doctrine of the Trinity in Church History." Reformation \& Revival 10, no. 3 (2001): 53-66.

Henry, Matthew. Commentary on the Whole Bible. Peabody, Mass.: Hendickson Publishers, 2008.

Henry, Matthew. A Method for Prayer, with Scripture Expressions Proper to be Us'd under Each Head. London: Nath. Cliff and Daniel Jackson, 1710.

Heyd, Michael. "Be Sober and Reasonable": The Critique of Enthusiasm in the Seventeenth and Early Eighteenth Centuries. Leiden: Brill, 1995.

Hill, Christopher. The Century of Revolution, 1603-1714. Walton-on-Thames: Nelson, 1980.

Hood, Edwin Paxton. Isaac Watts: his Life and Writings, his Homes and Friends. London: Religious Tract Society, 1875.

Hoppit, Julian. A Land of Liberty? England, 1689-1727. Oxford: Clarendon Press, 2000.

Horsley, John. A Brief Reply to the Scriptural and Argumentative Part of Mr. Bennet's Brief history of the Joint Use of Precomposed Set Forms of Prayer. London: Whattoff Boulter, 1708.

Howell, Wilbur Samuel. Eighteenth Century British Logic and Rhetoric. Princeton: Princeton University Press, 1971.

Hoyles, John. The Waning of the Renaissance, 1640-1740: Studies in the Thought and Poetry of Henry More, John Norris, and Isaac Watts. The Hague: Martinus Nijhoff, 1971.

Hudson, Nicholas. Samuel Johnson and Eighteenth Century Thought. Oxford: Clarendon, 1988.

Hull, John M. "From Experiential Educator to Nationalist Theologian: The Hymns of Isaac Watts." Bulletin of the Hymn Society of Great Britain \& Ireland 19, no. 7 (2010): 260.

Hunt, Arnold. The Art of Hearing: English Preachers and their Audiences, 1590-1640. Cambridge: Cambridge University Press, 2010. 
Hutcheson, Francis. An Essay on the Nature and Conduct of the Passions and Affections. London: S. Powell, 1728.

Ihalainen, Pasi. "The Enlightenment Sermon: Towards Practical Religion and a Sacred National Community." In Preaching, Sermon and Cultural Change in the Long Eighteenth Century, edited by Joris van Eijnatten. Leiden: Brill, 2009.

Irwin, Joyce. "The Theology of "Regular Singing"." New England Quarterly 51, no. 2 (1978): 176-92.

Jackson, John. A Plea for Humane Reason, Shewing the Sufficiency of it in Matters of Religion. London: J. Roberts, 1730.

James, Susan. Passion and Action: The Emotions in Seventeenth-Century Philosophy. Oxford: Clarendon Press, 1997.

James, Susan. "The Passions and the Good Life." In The Cambridge Companion to Early Modern Philosophy, edited by Donald Rutherford. Cambridge: Cambridge University Press, 2006.

James, Susan. "The Passions in Metaphysics and the Theory of Action." In The Cambridge History of Seventeenth-Century Philosophy, edited by Daniel Garber and Michael Ayers. Cambridge: Cambridge University Press, 1998.

James, Susan. "Reason, the Passions, and the Good Life." In The Cambridge History of Seventeenth-Century Philosophy, edited by Daniel Garber, Michael Ayers, Roger Ariew and Alan Gabbey. Cambridge: Cambridge University Press, 1998.

Jennings, David. A Sermon Occasioned by the Death of the Late Reverend Isaac Watts D.D. Preached to the Church of which he was Pastor. December 11, 1748. London: J. Oswald and W. Dilly, 1749.

Jennings, John. Two Discourses: The First Of Preaching Christ; the Second Of Particular and Experimental Preaching. London: John and Barham Clark, 1723.

Johnson, Samuel. A Dictionary of the English Language. London: W. Strahan, 1755.

Jolley, Nicholas. "Locke on Faith and Reason." In The Cambridge Companion to Locke's "Essay Concerning Human Understanding", edited by Lex Newman. Cambridge: Cambridge University Press, 2007.

Jones, Robert Tudor. Congregationalism in England, 1662-1962. London: Independent Press, 1962.

Joy, Louise. "Literary Affections: Categorization of the Emotions in Eighteenth-Century Writing." University of Cambridge, 2007.

Julian, John. A Dictionary of Hymnology. London: John Murray, 1892.

Keach, Benjamin. The Breach Repaired in God's Worship, or, Singing of Psalms, Hymns, and Spiritual Songs, Proved to be an Holy Ordinance of Jesus Christ with an Answer to all Objections. London: John Hancock, 1691.

Keeble, N. H. "Richard Baxter's Preaching Ministry: its History and Texts." The Journal of Ecclesiastical History 35, no. 4 (1984): 539-59.

Knott, John R. The Sword of the Spirit: Puritan Responses to the Bible. Chicago: University of Chicago Press, 1980.

Kuehn, Manfred. "Knowledge and Belief." In The Cambridge History of EighteenthCentury Philosophy, edited by Knud Haakonssen. Cambridge: Cambridge University Press, 2006.

Law, William. The Case of Reason, or Natural Religion, Fairly and Fully Stated. London: W. Innys, 1731.

Law, William. A Serious Call to a Devout and Holy Life. London: William Innys, 1729.

Leaver, Robin A. "Isaac Watts's Hermeneutical Principles and the Decline of English Metrical Psalmody." Churchman 92, no. 1 (1978): 56-60. 
Lennon, M. Thomas. "Locke on Ideas and Representation." In The Cambridge Companion to Locke's "Essay Concerning Human Understanding", edited by Lex Newman. Cambridge: Cambridge University Press, 2007.

Lessenich, Rolf Peter. Elements of Pulpit Oratory in Eighteenth-Century England, 1660-1800. Koln, Wien: Bohlau Verlag, 1972.

Levine, Joseph M. "Latitudinarians, Neoplatonists and the Ancient Wisdom." In Philosophy, Science and Religion in England 1640-1700, edited by Richard Kroll, Richard Ashcraft and Perez Zagorin, xv, 287p. Cambridge: Cambridge University Press, 1992.

Lindsay, Alexander. Index of English Literary Manuscripts 1700-1800. Vol. 3, Part 4. London: Mansell Publishing, 1997.

Locke, John. An Essay Concerning Human Understanding. Edited by P. H. Nidditch. Oxford: Clarendon Press, 1975.

Locke, John. An Essay Concerning Human Understanding: Abridged and Edited. Edited by Kenneth Winkler. Indianapolis, Ind.: Hackett Pub. Co., 1996.

Locke, John. A Paraphrase and Notes on the Epistles of St. Paul. Oxford: Clarendon Press, 1987.

Locke, John. The Reasonableness of Christianity as Delivered in the Scriptures. Bristol: Thoemmes, 1997.

Malherbe, Michel. "Reason." In The Cambridge History of Eighteenth-Century Philosophy, edited by Knud Haakonssen. Cambridge: Cambridge University Press, 2006.

Mandeville, Bernard. The Fable of the Bees: or, Private Vices Publick Benefits. London: J. Roberts, 1714.

Manning, Bernard. Essays in Orthodox Dissent. London: Independent Press, 1939.

Manning, Bernard L. The Hymns of Wesley and Watts. Five Informal Papers. London: Epworth Press, 1942.

Marini, Stephen. "Hymnody as History: Early Evangelical Hymns and the Recovery of American Popular Religion." Church History 71, no. 2 (2002): 273-306.

Marshall, Madeleine Forell, and Janet M. Todd. English Congregational Hymns in the Eighteenth Century. Lexington: University Press of Kentucky, 1982.

McClymond, Michael. "Jonathan Edwards." In The Oxford Handbook of Religion and Emotion, edited by John Corrigan, xii, 522 p. Oxford: Oxford University Press, 2008.

McCullough, Peter E., Hugh Adlington, and Emma Rhatigan. The Oxford Handbook of the Early Modern Sermon. Oxford: Oxford University Press, 2011.

McKim, Donald K. Ramism in William Perkins' Theology. New York: P. Lang, 1987.

McLachlan, Herbert. English Education under the Test Acts: Being the History of the Non-Comformist Academies, 1662-1820. Manchester Manchester University Press, 1931.

Meszaros, Andrew. "Isaac Watts: A Universal Hymn Writer." Bulletin of the Hymn Society of Great Britain \& Ireland 18, no. 11 (2008): 391.

Meyer, Susan Sauve, and Adrienne M. Martin. "Emotion and the Emotions." In The Oxford Handbook of the History of Ethics, edited by Roger Crisp. Oxford: Oxford University Press, forthcoming.

Miller, Perry. The New England Mind: The Seventeenth Century. Boston: Beacon Press, 1970.

Milner, John. The Rest and Reward of Good Men at Death. A Sermon Preached at Peckham-Surry, Dec.11. 1748. London: J. Noon, 1749. 
Milner, Thomas. The Life, Times and Correspondence of the Rev. Isaac Watts, D.D. London: Simpkin and Marshall, 1834.

Mitchell, William Fraser. English Pulpit Oratory from Andrewes to Tillotson. A Study of its Literary Aspects. London: S.P.C.K., 1932.

Montgomery, David J. "Isaac Watts and Artistic Kenosis: The Rationale Behind the Work of Britain's Pioneer Hymnwriter." Scottish Bulletin of Evangelical Theology 5 (1987): 174-84.

Morgan, John Philip. Godly Learning: Puritan Attitudes Towards Reason, Learning and Education, 1560-1640. Cambridge: Cambridge University Press, 1986.

Morrissey, Mary. "Scripture, Style and Persuasion in Seventeenth-Century English Theories of Preaching." Journal of Ecclesiastical History 53, no. 4 (2002).

Morsberger, Katharine M. "John Locke's 'An Essay Concerning Human Understanding': The Bible of the Enlightenment." Studies in Eighteenth Century Culture 25 (1996): 1-19.

Mortimer, Sarah. Reason and Religion in the English Revolution: the Challenge of Socinianism. Cambridge: Cambridge University Press, 2010.

Muller, Richard A. Post-Reformation Reformed Dogmatics: The Rise and Development of Reformed Orthodoxy. Grand Rapids, Mich.: Baker Academics, 2003.

Murray, Iain H. "The Directory for Public Worship." In To Glorify and Enjoy God: A Commemoration of the 350th Anniversary of the Westminster Assembly, edited by John L. Carson and David W. Hall, xiv,338p. Edinburgh: Banner of Truth Trust, 1994.

Murrey, Robert. Closet Devotions: In which the Principal Heads of Divinity are Meditated Upon, and Pray'd Over, in Scripture Expressions. London: John Lawrence, 1713.

Mursell, Gordon. English Spirituality: From 1700 to the Present Day. London: SPCK, 2001.

Nuovo, Victor. Christianity, Antiquity and Enlightenment: Interpretations of Locke. Dordrecht: Springer, 2011.

Nuttall, Geoffrey F. Beginnings of Nonconformity. London: James Clarke \& Co. Ltd, 1964.

Nuttall, Geoffrey F. "Continental Pietism and the Evangelical Movement in Britain." In Pietismus und Reveil, edited by Johannes van den Berg and J. P. van Dooren, vi, 386 p. Leiden: E. J. Brill, 1978.

Nuttall, Geoffrey F. The Holy Spirit in Puritan Faith and Experience. London: Basil Blackwell, 1946.

Nuttall, Geoffrey F. Richard Baxter. London: Nelson, 1965.

O'Brien, Susan. "Eighteenth-Century Publishing Networks in the First Years of Transatlantic Evangelicalism." In Evangelicalism, 38-57. Oxford: Oxford University Press, 1994.

Old, Hughes Oliphant. The Reading and Preaching of the Scriptures in the Worship of the Christian Church. Volume 4, The Age of the Reformation. Grand Rapids: W.B. Eerdmans, 1998.

Old, Hughes Oliphant. The Reading and Preaching of the Scriptures in the Worship of the Christian Church. Volume 5, Moderatism, Pietism, and Awakening. Grand Rapids: W.B. Eerdmans, 1998.

Orchard, Stephen. "The Hymns of Isaac Watts." Journal of the United Reformed Church History Society 6, no. 3 (1998): 155-67.

Owen, John. A Discourse of the Work of the Holy Spirit in Prayer. London: Nathanael Ponder, 1682. 
Owen, John. Exercitations Concerning the Name, Original, Nature, Use, and Continuance of a Day of Sacred Rest. London: R.W., 1671.

Owen, John. The Grace and Duty of Being Spiritually-Minded Declared and Practically Improved. London: J.G., 1681.

Owen, John. The True Nature of a Gospel Church and its Government. London: Printed for William Marshall, 1689.

Packer, J. I. Among God's Giants: Aspects of Puritan Christianity. Eastbourne: Kingsway, 1991.

Packer, J. I. The Redemption and Restoration of Man in the Thought of Richard Baxter: A Study in Puritan Theology. Carlisle: Paternoster Press, 2003.

Palmer, Samuel. The Protestant-Dissenter's Catechism. London: J. Buckland, 1774.

Parry, K. L. "Isaac Watts: Hymn-Writer and Divine." Listener (1948): 841.

Peaston, A. E. . The Prayer Book Tradition in the Free Churches. London: James Clarke \& Co., 1964.

Perkins, William. The Arte of Prophecying. London: Felix Kyngston, 1607.

Porter, Roy. Enlightenment: Britain and the Making of the Modern World. London: Allen Lane, 2000.

Post, Stephen G. Christian Love and Self-Denial: An Historical and Normative Study of Jonathan Edwards, Samuel Hopkins, and American Theological Ethics. Lanham: University Press of America, 1987.

Potkay, Adam. The Story of Joy: From the Bible to Late Romanticism. Cambridge: Cambridge University Press, 2007.

Practical Discourses Concerning the Duty of Prayer: Preach'd at the Friday EveningLecture in Eastcheap. By Several Ministers. London J. Darby, 1711.

Practical Discourses of Singing in the Worship of God; Preach'd at the Friday Lecture in Eastcheap. By Several Ministers. London: J. Darby, 1708.

Pratt, Anne S. Isaac Watts and his Gifts to Yale College. New Haven: Yale University Library, 1938.

Preston, John. The Breast-Plate of Faith and Love. London: W. J., 1630.

Preston, John. Riches of Mercy. London: F. Eglesfield, 1658.

Ramsey, Paul. "Introduction." In Freedom of the Will by Jonathan Edwards. New Haven: Yale University Press, 1957.

Redwood, John. Reason, Ridicule and Religion: The Age of Enlightenment in England, 1660-1750. London: Thames and Hudson, 1976.

Rehnman, Sebastian. Divine Discourse: The Theological Methodology of John Owen. Grand Rapids: Baker Book House, 2002.

Reynolds. "Directions for the Gift and Grace of Prayer." In Practical Discourses Concerning the Duty of Prayer: Preach'd at the Friday Evening-Lecture in Eastcheap. By Several Ministers. London: J. Darby, 1711.

Reynolds, Edward. A Treatise of the Passions and Faculties of the Soule of Man. London: R. H., 1640.

Richardson, Caroline Francis. English Preachers and Preaching, 1640-1670: A Secular Study. New York: Macmillan, 1928.

Richey, Russell E. "From Puritanism to Unitarianism in England: A Study in Candour " Journal of the American Academy of Religion 41, no. 3 (1973): 371-85.

Ridpath, George. An Answer to The Scotch Presbyterian Eloquence. London: Tho. Anderson, 1693.

Ritchie, Daniel E. The Fullness of Knowing: Modernity and Postmodernity from Defoe to Gadamer. Waco: Baylor University Press, 2010. 
Rivers, Isabel. Reason, Grace and Sentiment: A Study of the Language of Religion and Ethics in England 1660-1780. Volume 1, Whichcote to Wesley. Cambridge: Cambridge University Press, 1991.

Rivers, Isabel. Reason, Grace and Sentiment: A Study of the Language of Religion and Ethics in England, 1660-1780, Volume 2, Shaftesbury to Hume. Cambridge: Cambridge University Press, 2000.

Rivers, Isabel. "Religion and Literature." In The Cambridge History of English Literature, 1660-1780, edited by John Richetti. Cambridge: Cambridge University Press, 2005.

Rivers, Isabel. "Shaftesburian Enthusiasm and the Evangelical Revival." In Revival and Religion since 1700: Essays for John Walsh, edited by Jane Garnett, H. C. G. Matthew and John Evangelist Walsh, xi,330p. London: Hambledon, 1993.

Rivers, Isabel, and David L. Wykes. Dissenting Praise: Religious Dissent and the Hymn in England and Wales. Oxford: Oxford University Press, 2011.

Rogal, Samuel J. A General Introduction to Hymnody and Congregational Song. Philadelphia: American Theological Library Association, 1991.

Rogal, Samuel J. "Isaac Watts' London printers, publishers, and booksellers (17001748)." Yale University Library Gazette (1972): 167.

Rogal, Samuel J. "Watts' Divine and Moral Songs for Children and the Rhetoric of Religious Instruction." Historical Magazine of the Protestant Episcopal Church 40, no. 1 (1971): 95-100.

Rogers, G. A. R. "Locke and the Latitude-Men: Ignorance as a Ground of Toleration." In Philosophy, Science and Religion in England 1640-1700, edited by Richard Kroll, Richard Ashcraft and Perez Zagorin, xv, 287p. Cambridge: Cambridge University Press, 1992.

Romaine, William. An Essay on Psalmody. London: 1775.

Roodenburg, Herman. "Si vis me flere...: On Preachers, Passions and Pathos in Eighteenth-Century Europe." In Myths, Martyrs, and Modernity, 609-28. Leiden: Brill, 2010.

Roodenburg, Herman Willem. "From Embodying the Rules to Embodying Belief: On Eighteenth-Century Pulpit Delivery in England, Germany and the Netherlands." In Preaching, Sermon and Cultural Change in the Long Eighteenth Century, edited by Joris Van Eijnatten. Leiden: Brill, 2009.

Rosenblatt, Helena. "The Christian Enlightenment." In Enlightenment, Reawakening and Revolution 1660-1815, edited by J. Stewart Brown and Timothy Tackett. Cambridge: Cambridge University Press, 2006.

Routley, Erik. "Eucharistic Hymns of Isaac Watts." Worship 48, no. 9 (1974): 526-35. Rupp, Gordon. Religion in England 1688-1791, Oxford history of the Christian Church. Oxford: Clarendon Press, 1986.

Ryken, Leland. Worldly Saints: The Puritans As They Really Were. Grand Rapids: Zondervan Publishing House, 1986.

Sacheverell, Henry. A New Form of Prayer for Morning and Evening, for the Use of Families Zealously Affected to the Establish'd Church. London: J. Baker, 1710.

Schneewind, B. Jerome. "The Active Powers." In The Cambridge History of Eighteenth-Century Philosophy, edited by Knud Haakonssen. Cambridge: Cambridge University Press, 2006.

Scholes, Percy Alfred. The Puritans and Music - in England and New England. A Contribution to the Cultural History of Two Nations. London: Oxford University Press, 1934. 
Sell, Alan P. F. Dissenting Thought and the Life of the Churches: Studies in an English Tradition. San Francisco: Mellen Research University Press, 1990.

Sell, Alan P. F. John Locke and the Eighteenth-Century Divines. Cardiff: University of Wales Press, 1997.

Sell, Alan P. F. "Philosophy in the Eighteenth Century: Dissenting Academies of England and Wales." History of Universities XI (1992): 75-122.

Sell, Alan P. F. Philosophy, Dissent and Nonconformity. Cambridge: James Clarke, 2004.

Sell, Alan P. F. "The Worship of English Congregationalism." In Christian Worship in Reformed Churches Past and Present, edited by Lukas Vischer. Grand Rapids: W.B. Eerdmans, 2003.

Shaftesbury, Lord. Characteristicks of Men, Manners, Opinions, Times. London: John Darby, 1711.

Shaw, Jane. "Mary Toft, Religion and National Memory in Eighteenth Century England." Journal for Eighteenth-Century Studies 32, no. 3 (2009): 321-38.

Sherlock, Thomas. Several Discourses Preached at the Temple Church. London: J. Whiston and B. White, W. Owen, and E. Baker, 1754.

Sibbes, Richard. A Fountain Sealed: or, The duty of the Sealed to the Spirit, and the Worke of the Spirit in Sealing. London: Thomas Harper, 1637.

Skinner, Quentin. Visions of Politics. Vol. 1. Cambridge: Cambridge University Press, 2002.

Skoglund, John E. "Free Prayer." Studia Liturgica 10, no. 3/4 (1974).

Skouen, Tina. "Science versus Rhetoric? Sprat's History of the Royal Society Reconsidered." Rhetorica: A Journal of the History of Rhetoric 29, no. 1 (2011): 23-52.

Smith, John E. "Introduction." In Religious Affections by Jonathan Edwards, 526 p. New Haven: Yale University Press, 1959.

Smyth, Charles. The Art of Preaching: A Practical Survey of Preaching in the Church of England, 747-1939. London: S.P.C.K., 1940.

Spellman, W. M. John Locke and the Problem of Depravity. Oxford: Clarendon Press, 1988.

Spinks, Brian D. Freedom or Order?: The Eucharistic Liturgy in English Congregationalism, 1645-1980. Allison Park, Pa.: Pickwick Publications, 1984.

Spinks, Bryan D. "The Origins of the Antipathy to Set Liturgical Forms in the EnglsihSpeaking Reformed Tradition." In Christian Worship in Reformed Churches Past and Present, edited by Lukas Vischer. Grand Rapids: W. B. Eerdmans, 2003.

Sprat, Thomas. The History of the Royal-Society of London. London: T. R., 1667.

Spurr, J. "Rational Religion in Restoration England." Journal of the History of Ideas 49, no. 4 (1988): 563-85.

Spurr, John. "Later Stuart Puritanism." In The Cambridge Companion to Puritanism, edited by John Coffey and Paul Chang-Ha Lim, xi, 385 p. Cambridge: Cambridge University Press, 2008.

Stebbing, Henry. Discourses Upon Several Subjects. London: Jonah Bowyer, 1722.

Steele, Richard B. "Gracious Affection" and "True Virtue" According to Jonathan Edwards and John Wesley, Pietist and Wesleyan studies. London: Scarecrow, 1994.

Stennett, Joseph. Hymns Compos'd for the Celebration of the Holy Ordinance of Baptism: John Marshall, 1695. 
Stennett, Joseph. Hymns in Commemoration of the Sufferings of Our Blessed Saviour Jesus Christ Compos'd for the Celebration of His Holy Supper. London: J. Darby, 1697.

Stephens, Isaac. "Confessional Identity in Early Stuart England: The "Prayer Book Puritanism" of Elizabeth Isham " Journal of British Studies 50, no. 1 (2011): 2447.

Stephenson, William E. "Isaac Watts's Education for the Dissenting Ministry, a New Document." Harvard Theological Review 61, no. 2 (1968): 263-81.

Stewart, A. M. "Revealed Religion: The British Debate." In The Cambridge History of Eighteenth-Century Philosophy, edited by Knud Haakonssen. Cambridge: Cambridge University Press, 2006.

Stewart, M. A. Independency of the Mind in Early Dissent. London: Congregational Memorial Hall Trust, 2004.

Strivens, Robert. "The Thought of Philip Doddridge in the Context of Early EighteenthCentury Dissent ", University of Stirling, 2011.

Strom, Jonathan. "Pietism and Revival." In Preaching, Sermon and Cultural Change in the Long Eighteenth Century, edited by Joris van Eijnatten, xiv, 413 p. Leiden: Brill, 2009.

Stromberg, Roland N. Religious Liberalism in Eighteenth-Century England. London: Oxford University Press, 1954.

Tallon, Andrew. "Christianity." In The Oxford Handbook of Religion and Emotion, edited by John Corrigan, xii, 522 p. Oxford: Oxford University Press, 2008.

Targoff, Ramie. Common Prayer: The Language of Public Devotion in Early Modern England. Chicago: University of Chicago Press, 2001.

Taylor, John H. . "Isaac Watts' Guide to Prayer." Transactions of the Congregational Historical Society XVIII (1956-1959).

Thiel, Udo. "Religion and Material Metaphysics: Some Aspects of the Debate about the Resurrection of the Body in Eighteenth-Century Britain." In Philosophy and Religion in Enlightenment Britain, edited by Ruth Savage. Oxford: Oxford University Press, 2012.

Thompson, Andrew C. "What Isaac Watts and Philip Doddridge Were Doing When They Were Not Writing Hymns." Journal of the United Reformed Church History Society 6, no. 7 (2000): 469-82.

Tindal, Matthew. Christianity as Old as the Creation: or, the Gospel, a Republication of the Religion of Nature. London 1730.

Tottie, John. A View of Reason and Passion, as in their Original and Present State. London: C. Rivington, 1738.

"Transactions of the Congregational Historical Society." VI (1913-15).

van Asselt, Willem J. Introduction to Reformed Scholasticism. Edited by Joel R. Beeke and Jay T. Collier, Reformed Historical-Theological Studies. Grand Rapids: Reformation Heritage Books, 2011.

van den Berg, J. "The Idea of the Pre-Existence of the Soul of Christ: An Argument in the Controversy between Arian and Orthodox in the Eighteenth Century." In Tradition and Reinterpretation in Jewish and Early Christian Literature, edited by J. W. van Henten, pp. 284-95. Leiden: E. J. Brill, 1986.

VanDrunen, David. Natural Law and the Two Kingdoms: A Study in the Development of Reformed Social Thought. Grand Rapids, Mich.: Eerdmans, 2010.

Wainewright, Jeremiah. Brief Remarks on Mr. Bennet's Brief History of the Joint Use of Precomposed Set Forms of Prayer. London: J. Humfreys, 1708. 
Wallace, Dewey D. Shapers of English Calvinism, 1660-1714: Variety, Persistence, and Transformation. Oxford: Oxford University Press, 2011.

Ward, Andrew. "Introduction." In On the Nature and Conduct of the Passions with Illustrations on Moral Sense, 1728, by Francis Hutcheson. Manchester: Clinamen, 1999.

Ward, W. Reginald. Christianity under the Ancien Régime, 1648-1789. Cambridge: Cambridge University Press, 1999.

Watson, J. R. The English Hymn: A Critical and Historical Study. Oxford: Clarendon Press, 1997.

Watson, J. R. "The Hymns of Isaac Watts and the Tradition of Dissent." In Dissenting praise: Religious Dissent and the Hymn in England and Wales, edited by Isabel Rivers and David L. Wykes. Oxford: Oxford University Press, 2011.

Watts, Isaac. A Guide to Prayer. Edinburgh: Banner of Truth Trust, 2001.

Watts, Isaac. Isaac Watts's A Guide to Prayer. Abridged and Edited by Harry Escott. London: Epworth Press, 1948.

Watts, Isaac. "Letter to a lady about inward impulses." London: British Library.

Watts, Isaac. "Letter to Samuel Say, 7 Spetember 1732." London: Dr Williams's Library, 1732.

Watts, Isaac. "Letter to Samuel Say, 29 July 1732." London: Dr Williams's Library, 1732.

Watts, Isaac. "Letter to younger brother." London: British Library, 1699.

Watts, Isaac. "Letters." Proceedings of the Massachusetts Historical Society 9 (1894): 301-549.

Watts, Isaac. The Posthumous Works of the Late Learned and Reverend Isaac Watts, D.D. In two volumes. Compiled from papers in possession of his immediate successors: adjusted and published by a gentleman of the University of Cambridge. London: T. Becket and J. Bew, 1779.

Watts, Isaac. "Preface." In Devout Exercises of the Heart in Meditation and Soliloquy, Prayer and Praise, by Elizabeth Singer Rowe. London: R. Hett, 1738.

Watts, Isaac. "Sermon Manuscripts." London: British Library, 1702.

Watts, Isaac. "Wattiana: Manuscript Remains of the Rev Isaac Watts, DD, from the Library of Mr Joseph Parker, his Amanuensis." London: British Library.

Watts, Isaac. The Works of the Late Reverend and Learned Isaac Watts, D.D. published by himself, and now collected into six volumes. Revised and corrected by D. Jennings, D.D. and the late P. Doddridge, D.D. London: T. and T. Longman, and J. Buckland; J. Oswald; J. Waugh; and J. Ward, 1753.

Watts, Isaac, and Hal McElwaine Helms. So Amazing, So Divine: A Guide to Living Prayer. Brewster, Mass.: Paraclete Press, 1997.

Watts, Michael R. The Dissenters. Oxford: Clarendon Press, 1978.

Webb, R. K. "The Emergence of Rational Dissent." In Enlightenment and Religion: Rational Dissent in Eighteenth-Century Britain, edited by Knud Haakonssen, xii,348p. Cambridge: Cambridge University Press, 1996.

Webber, F. R. A History of Preaching in Britain and America. Milwaukee: Northwestern Publishing House, 1952.

Weemes, John. The Pourtraiture of the Image of God in Man. London: M. Flesher and G. Wood, 1627.

Wesley, John. Letters of John Wesley. Edited by George Eayrs. London: Hodder \& Stoughton, 1915.

White, Daniel E. Early Romanticism and Religious Dissent. Cambridge: Cambridge University Press, 2006. 
White, Eugene Edmond. Puritan Rhetoric: The Issue of Emotion in Religion. Carbondale: Southern Illinois University Press, 1972.

White, James F. Protestant Worship: Traditions in Transition. Louisville, Ky.: Westminster/John Knox Press, 1989.

Whitehouse, Marie Therese. "Isaac Watts and Philip Doddridge: Letters, Lectures and Lives and Eighteenth-Century Dissenting Culture." University of London, 2011.

Wilkins, John. A Discourse Concerning the Gift of Prayer. London: T.R. and E.M., 1651.

Wilkins, John. Ecclesiastes, or, a Discourse Concerning the Gift of Preaching as it Falls under the Rules of Art. London: M. F., 1646.

Wilson, Samuel. The Duties of a Pastor and Deacons. London: John Wilson, 1736.

Wojcik, Jan W. Robert Boyle and the Limits of Reason. Cambridge: Cambridge University Press, 2002.

Wolterstorff, Nicholas. John Locke and the Ethics of Belief. Cambridge: Cambridge University Press, 1996.

Wolterstorff, Nicholas. "Locke's Philosophy of Religion." In The Cambridge Companion to Locke, edited by Vere Chappell. Cambridge: Cambridge University Press, 1994.

Woolhouse, Roger. "Locke's Theory of Knowledge." In The Cambridge Companion to Locke, edited by Vere Chappell. Cambridge: Cambridge University Press, 1994.

Wright, Clifford J. "Isaac Watts: The Man, his Mind and Message." Modern Churchman 38, no. 4 (1948): 348-56.

Wright, Thomas. Issac Watts and Contemporary Hymn-Writers. Vol. 3. London: C. J. Farncombe \& Sons, 1914.

Wykes, David L. "The Contribution of the Dissenting Academy to the Emergence of Rational Dissent." In Enlightenment and Religion: Rational Dissent in Eighteenth-Century Britain, edited by Knud Haakonssen. Cambridge: Cambridge University Press, 1996.

Yolton, John. "Introduction." In Philosophical Essays on Various Subjects: With Some Remarks on Mr Locke's Essay on the Human Understanding, 1742, by Watts, Isaac., xiii,407p. Bristol: Thoemmes, 1990.

Yolton, John. John Locke and the Way of Ideas. London: Oxford University Press, 1956.

Young, B. W. Religion and Enlightenment in Eighteenth-Century England: Theological Debate from Locke to Burke. Oxford: Clarendon Press, 1998.

Young, Edward. A Vindication of Providence: Or, A True Estimate of Human Life. In which the Passions are Consider'd in a New Light. London: T. Worrall, 1728. 